UNIVERSIDADE DE SÃO PAULO

FACULDADE DE EDUCAÇÃO

PROGRAMA DE PÓS-GRADUAÇÃO EM EDUCAÇÃO

CARLA SILVINO DE OLIVEIRA

A Base Nacional Comum Curricular: disputas em torno da seleção curricular para o Ensino de História 
CARLA SILVINO DE OLIVEIRA

\title{
A Base Nacional Comum Curricular: disputas em torno da seleção curricular para o Ensino de História
}

\author{
Versão Corrigida
}

Tese apresentada à Faculdade de Educação da Universidade de São Paulo para obtenção do título de Doutora em Educação.

Área de concentração: Didática, Teorias de Ensino e Práticas Escolares

Orientadora: Profa. Dra. Cláudia Valentina Assumpção Galian 
Autorizo a reprodução e divulgação total ou parcial deste trabalho, por qualquer meio convencional ou eletrônico, para fins de estudo e pesquisa, desde que citada a fonte.

Ficha elaborada pelo Sistema de Geração Automática a partir de dados fornecidos pelo(a) autor(a) Bibliotecária da FE/USP: Nicolly Soares Leite - CRB-8/8204

ob

Oliveira, Carla silvino de

A Base Naci onal Cormun Curricular - di sputas en torno da seleçăo curricular para o Ensino de Hi storia / Carla silvino de oliveira; orientadora claudia valentina Assumpção Galian. -- são paulo, 2021. $176 \mathrm{p}$.

Tese (Doutorado - Programa de pos-Grachıção Fornação, curriculo e práticas pedagogi cas) -Faculdade de Echıcąão, universidade de são paulo, 2021 .

1. Currículo. 2. Base Nacional camun curricular (BNCC). 3. Historia. 4. Ensino Fundamental. I. Galian, cláudi a valentina As sump̧ăo, orient. II. Titulo. 
Nome: OLIVEIRA, Carla Silvino de

Título: A Base Nacional Comum Curricular: disputas em torno da seleção curricular para o Ensino de História.

Tese apresentada à Faculdade de Educação da Universidade de São Paulo para obtenção do título de Doutora em Educação.

Aprovada em: 14 de julho de 2021

\section{Banca Examinadora}

Profa. Dra. Claudia Valentina Assumpção Galian

Instituição: FE - USP

Julgamento:

Profa. Dra. Isabel Melero Bello

Instituição: UNIFESP - Externo

Julgamento:

Prof. Dr. Mauro Cezar Coelho

Instituição: UFPA - Externo

Julgamento:

Prof. Dr. Marcelo Fronza

Instituição: UFMT - Externo

Julgamento:

Profa. Dra. Ana Carla Sabino Fernandes

Instituição: UFCE - Externo

Julgamento: 

Às mulheres, que vivenciaram a pesquisa e maternagem em tempos pandêmicos da Covid - 19

Aos trabalhadores da educação, que defendem o ensino crítico e transformador Aos meus amores, Edinielson e Yves 


\section{AGRADECIMENTOS}

Ao Edinielson Figueiredo, por seu carinho, companheirismo e incentivo em mais um momento acadêmico, por sua prontidão na escuta e leitura desta tese

Ao Yves Silvino, por dividir o tempo da maternagem com a pesquisa

À professora Cláudia Galian, por sua orientação dedicada, sensível e humana. Agradeço o acolhimento no momento mais difícil da pesquisa, por acreditar e tornar esta experiência agradável, leve, alegre e desejável, és minha inspiração para vida e docência

Ao Grupo de Pesquisa Escola, Currículo e Conhecimento - ECCo, coordenado pela professora Cláudia Galian, por contribuir com as discussões sobre a Base Nacional Comum Curricular

Às professoras Isabel Bello e Circe Bittencourt, por comporem a banca de qualificação e, por suas observações e sugestões, que contribuíram na composição desta tese e que prontamente aceitaram compor a banca final, juntamente com os professores Marcelo Fronza e Mauro Coelho

À professora Dislane Zerbinatti, por seu acolhimento inicial no programa de pós-graduação da FE-USP

Aos coordenadores do Doutorado Interinstitucional em Educação FE-USP/UFPI, professor Agnaldo Arroio e professora Germaine Elshout, pela condução competente do programa Aos professores e alunos do Doutorado Interinstitucional em Educação FE-USP/UFPI, pela colaboração acadêmica

À professora Isabel Almeida, por sua acolhida acadêmica e afetiva

À professora Isabel Barca, por suas sugestões e discussões no campo da Educação Histórica As instituições, Universidade de São Paulo e Universidade do Porto, por possibilitar a realização do doutorado sanduíche

À Universidade Federal do Piauí, onde exerço a profissão da docência, por ter me concedido afastamento para fazer este doutorado

Aos professores do Curso de História da Universidade Federal do Piauí (CSHNB), em especial aos companheiros Mairton Celestino e Gleison Monteiro, pelo incentivo e apoio institucional 
Aos meus pais Carlos Batista e Graça Silvino e ao meu irmão Clairton Silvino, pelo carinho e apoio incondicional

Aos amigos, Leonardo Severo, Simone Batista e Jânio Ribeiro, pelas discussões e indicações de leituras na área da Educação

Aos amigos, Nágila Maia, Priscila Lisboa, Alana Holanda, Érica Lôpo, Jean Carlos, Ada Raquel, Ana Alice, Tito Barros, Paulo Passos, Aleksandra Braga, Nívia Sirido, Danielle Oliveira, Ticiana Antunes, Erllen Sousa, Olivina Pimenta, D’jê Araújo pelo apoio, carinho e incentivo para a realização desta pesquisa

À Faculdade de Educação da Universidade de São Paulo, na qual defendi esta tese 
"A crise da Educação no Brasil não é uma crise; é um projeto"

Darcy Ribeiro 


\section{RESUMO}

OLIVEIRA, Carla Silvino de. A Base Nacional Comum Curricular: disputas em torno da seleção curricular para o Ensino de História. 2021. Tese (Doutorado em Educação) Faculdade de Educação, Universidade de São Paulo, São Paulo, 2021.

A pesquisa analisou o processo de definição do conhecimento selecionado como relevante nos documentos curriculares da disciplina de História. Para isso, identificamos as disputas em torno do conhecimento a ser selecionado para o Ensino de História durante o processo de elaboração da BNCC, reconhecemos como elas se relacionam ao debate sobre esse tema em contextos anteriores à Base e por fim, identificamos e discutimos as permanências e mudanças nas escolhas curriculares operadas no período em análise. Os objetivos foram alcançados por meio da análise documental dos ofícios encaminhados ao CNE e produzidos pela ANPUH, UNDIME, ANPEd e Movimento pela Base, pela análise bibliográfica das produções acadêmicas sobre currículo e Ensino de História, publicadas no período de 2000 a 2017 e por fim, através da análise do Parecer CNE/CP n ${ }^{\circ} 15 / 2017$, e da versão final da BNCC, no trecho que se refere ao Ensino Fundamental - anos finais. A triangulação dos dados identificou mudanças curriculares em relação ao conhecimento da disciplina. A primeira mudança é o deslocamento, da ênfase no conhecimento disciplinar para as competências socioemocionais - expressas nas habilidades, atitudes e valores afirmados na BNCC. A segunda mudança é o deslocamento da atenção do processo de ensino para o de aprendizagem. Dessa forma, concluímos que as vozes silenciadas divergiram das escolhas curriculares e dos movimentos de deslocamento antes referidos, alinhados aos interesses do contexto político-econômico. As vozes efetivamente ouvidas, coerentes com esses deslocamentos, são legitimadas e alinhadas aos posicionamentos de entidades internacionais do capital neoliberal. Diante do exposto, consideramos que a pesquisa contribui para ampliar os elementos que embasam as reflexões sobre o Conhecimento Histórico Escolar nos debates da História Social do Currículo, e também com a apresentação de uma forma de analisar o conhecimento histórico escolar, conferindo atenção a aspectos diversos na leitura de fontes distintas: a justificativa para a presença do componente no currículo escolar; a fundamentação teórica escolhida para os documentos, no campo das correntes historiográficas; os conceitos estruturantes selecionados para a disciplina; a organização do conhecimento; os temas e conteúdos historiográficos e os processos metodológicos da investigação histórica. A pesquisa proporciona, assim, elementos para a leitura crítica da versão final da BNCC História e para futuras seleções curriculares, discutindo seus possíveis avanços e limitações.

Palavras-chave: Currículo. Base Nacional Comum Curricular (BNCC). História. Ensino Fundamental. 


\begin{abstract}
OLIVEIRA, Carla Silvino de. The National Common Core Curriculum: disputes around the curricular selection for the teaching of History. 2021. Thesis (Doctorate degree on Education) - School of Education, University of São Paulo, São Paulo, 2021
\end{abstract}

The research analyzed the process of defining the knowledge selected as relevant in the curricular documents of the discipline of History. For that, we identified the disputes around the knowledge to be selected for teaching History during the process of elaborating BNCC. We recognized how it relates to the debate on this topic in contexts prior to this document and finally, we identified and discussed the permanences and changes in the curricular choices made in the analyzed context. The aims were achieved through the documental analysis of the official texts forwarded to the CNE and produced by ANPUH, ANDIME, ANPEd and Movimento pela Base, through the bibliographic analysis of the academic production about curriculum and History teaching published in the period from 2000 to 2017. Ultimately, we developed the analysis of the Parecer CNE/CP n ${ }^{\circ} 15 / 2017$ and the BNCC's final version in the section that refers to Elementary school - final grades. The triangulation of data identified curricular changes tied to the discipline's knowledge. The first change is the displacement from the emphasis in the disciplinary knowledge to the socioemotional competences expressed in skills, attitudes and values stated in BNCC. The second change is the attention's displacement from the teaching process to the learning process. Thus, we concluded that the silenced voices diverged from the curricular choices and the displacement moviments, aligned to the interests of the political-economic context. The voices effectively heard, consistent with these displacements, are legitimized and aligned to the statements of the international entities of the neoliberal capital. From that, we considered that the research contributes to expand the elements that base the reflections about the School History Knowledge on debates of Social History Curriculum. Furthermore, we introduced a way to analyze the school history knowledge by putting attention on several aspects on distincts sources - such as the justification for the presence of the component in the school's curriculum; the theoretical foundation chosen for the documents in the historiographic currents' field; the structuring concepts selected to be taught; the organization of knowledge; the historiographic subjects and contents and the methodological processes of the historical investigation. The research thus provides elements for the critical reading of the final version of BNCC History and for future curricular selections, discussing its possible advances and limitations.

Keywords: Curriculum. National Common Core Curriculum (BNCC). History. Elementary school. 


\section{LISTA DE SIGLAS}

ABdC Associação Brasileira de Currículo

ANPAE Associação Nacional de Política e Administração da Educação

ANPEd Associação Nacional de Pós-Graduação e Pesquisa em Educação

ANPUH Associação Nacional de História

BDTD Biblioteca Digital Brasileira de Teses e Dissertações

BM Banco Mundial

BNCC Base Nacional Comum Curricular

CAPES Coordenação de Aperfeiçoamento de Pessoal de Nível Superior

CEDES Centro de Estudos Educação e Sociedade

CIEB Centro de Inovação para a Educação Brasileira

CNE Conselho Nacional de Educação

CONSED Conselho Nacional de Secretários de Educação

$\mathrm{CP} \quad$ Conselho Pleno

DCN Diretrizes Curriculares Nacionais

DEDALUS Catálogo Coletivo das Bibliotecas da USP

DINTER Doutorado Interinstitucional

DO Diário Oficial

FEUSP Faculdade de Educação da USP

IAS Instituto Airton Sena

LDB Lei de Diretrizes e Bases da Educação

MEC Ministério da Educação

MESP Movimento Escola Sem Partido

NSE Nova Sociologia da Educação

PCN Parâmetros Curriculares Nacionais

PNE Plano Nacional de Educação

SBC Sociedade Brasileira de Computação

SIBi Sistema Integrado de Bibliotecas da USP

TCC Trabalho de Conclusão de Curso

UFPI Universidade Federal do Piauí

UNDIME União Nacional dos Dirigentes Municipais de Educação

USP Universidade de São Paulo 


\section{LISTA DE QUADROS}

Quadro 1 - Produção acadêmica: Conhecimento/Conteúdo no Currículo Prescrito Oficial

Quadro 2 - Produção acadêmica: Diversidade Cultural, Patrimônio Cultural e História Regional

Quadro 3 - Currículo e Base Nacional Comum Curricular - BNCC

Quadro 4 - Produção acadêmica sobre currículo e Ensino de História

Quadro 5 - Relação dos documentos encaminhados ao CNE que tratam do componente curricular de História

Quadro 6 - Relação das falas realizadas nas Audiências Públicas que contemplam o componente curricular de História

Quadro 7 - Relação das falas realizadas nas Audiências Públicas pela ANPUH e localização da documentação

Quadro 8 - Documentos curriculares analisados no inventário da produção acadêmica sobre Currículo e Ensino de História

Quadro 9 - Relação dos documentos encaminhados ao CNE e as abordagens do componente curricular de História 


\section{LISTA DE ANEXOS}

ANEXO A - Documento encaminhado ao CNE pela ANPUH-SC (2017) - Ofício 059 Parecer da ANPUH-SC sobre a terceira versão da Base Nacional Comum Curricular de História

ANEXO B - Documento encaminhado ao CNE pela ANPUH-SP (2017) - Ofício 070 ANPUH-SP na Audiência sobre a Base Nacional Comum Curricular. Conselho Nacional de Educação - Comissão da Base Nacional Comum Curricular 


\section{SUMÁRIO}

INTRODUÇÃO 15

1 ESCOLHAS TEÓRICAS E METODOLÓGICAS 30

$\begin{array}{ll}1.1 \text { FUNDAMENTAÇÃO TEÓRICA } & 30\end{array}$

$\begin{array}{ll}\text { 1.1.1 Currículo } & 31\end{array}$

1.1.2 Conhecimento Histórico 38

\begin{tabular}{ll}
1.2 & METODOLOGIA \\
\hline
\end{tabular}

1.2.1 O contexto e o tipo de pesquisa 49

1.2.2 Os documentos 51

$\begin{array}{ll}\text { 1.2.3 Procedimentos e instrumentos } & 63\end{array}$

2 APRESENTAÇÃO E DISCUSSÃO DOS DADOS 67

2.1 A DEFINIÇÃO DO CONHECIMENTO HISTÓRICO NOS CURRICULOS ANTERIORES À BNCC 68

2.1.1 Apresentação das produções acadêmicas e dos documentos curriculares analisados 69

2.1.2 Aspectos do conhecimento histórico escolar expressos em documentos anteriores à BNCC 74

2.2 O CONHECIMENTO HISTÓRICO NO PROCESSO DE ELABORAÇÃO DA BNCC 98

2.2.1 Os sujeitos proponentes dos documentos e o lugar social ocupado por eles 98

2.2.2 Propostas para o componente curricular de História da BNCC 102

2.3 A BNCC E O COMPONENTE DE HISTÓRIA PARA O ENSINO FUNDAMENTAL - ANOS FINAIS 116

2.3.1 As escolhas curriculares do CNE: justificativas, impasses e aprovação da BNCC 116

2.3.2 Currículo, Conhecimento e Competências socioemocionais 119

2.3.3 Aspectos do conhecimento histórico na BNCC do Ensino Fundamental - anos finais $\quad 130$

$\begin{array}{ll}2.4 \text { TRIANGULAÇÃO DOS DADOS } & 141\end{array}$

CONSIDERAÇÕES FINAIS 152

$\begin{array}{ll}\text { REFERÊNCIAS } & 160\end{array}$

$\begin{array}{ll}\text { ANEXOS } & 170\end{array}$ 


\section{INTRODUÇÃO}

O lugar do Ensino de História na formação do historiador passa por constantes desafios e transformações. Durante minha formação inicial, vivenciei o dilema de conciliar as atividades acadêmicas da pesquisa com as da docência. Por muitas vezes, parecia que esses caminhos não poderiam ser interligados, e, muito menos, que o objeto de pesquisa poderia ser o Ensino de História.

Diante dos conflitos na formação dos historiadores, seja nos cursos de Licenciatura e/ou Bacharelado, convivi com a dicotomia na formação do professor de História e/ou historiador pesquisador. Mediante esse cenário, trilhei, como tantos outros companheiros, uma jornada que há uma década atrás era árdua e improvável: o ingresso do licenciado em História, nos programas de pós-graduação em História. Assim, participei do lento processo de reconhecimento e fortalecimento do Historiador professor-pesquisador, no contexto nacional. A conclusão do mestrado acadêmico, em 2007, foi a primeira batalha vencida, diante das que estavam por vir.

Ao ingressar na carreira do magistério no Ensino Superior, em 2008, as Diretrizes Curriculares dos Cursos de Licenciatura em História (BRASIL, 2001, 2002) orientavam a pesquisa acadêmica como parte da formação do docente, mas, ao mesmo tempo, a contradição persistia quando os pares não consideravam os temas do Ensino de História como objeto das pesquisas a serem desenvolvidas como Trabalho de Conclusão de Curso (TCC), relegando não só a pesquisa, mas as ações docentes no Ensino de História exclusivamente aos pedagogos. Isso gerava duas situações: a dificuldade no ingresso em programas de pósgraduação acadêmicos (mestrados e doutorados) em História com temas de pesquisas relacionados ao Ensino de História; e a segregação, nos currículos dos cursos de Licenciatura em História, das questões do ensino e da aprendizagem em História das questões epistemológicas do conhecimento histórico.

A segunda situação só poderia ser superada a partir dos resultados das pesquisas realizadas no campo do Ensino de História, no qual encontrei acolhimento, principalmente, nos programas de pós-graduação em Educação. Esse foi o caminho escolhido por mim ao desenvolver a pesquisa ora apresentada.

A pesquisa "A Base Nacional Comum Curricular: disputas em torno da seleção curricular para o Ensino de História" tem como objetivo central identificar quais conhecimentos históricos foram selecionados nos documentos curriculares e quais as 
permanências e rupturas manifestas no campo da formulação curricular de História nas últimas três décadas ${ }^{1}$. A pesquisa traça minha segunda experiência acadêmica, na qual almejo contribuir para a consolidação dos laços entre História e Cultura Escolar e o fortalecimento da pesquisa em Ensino de História, no campo do Currículo.

A escolha do tema ocorreu durante o processo de elaboração da Base Nacional Comum Curricular (BNCC) $)^{2}$ entre os meses de junho e setembro de 2017. Ao acompanhar as cinco audiências públicas, realizadas pelo Conselho Nacional de Educação (CNE), sobre a terceira versão do texto da BNCC, identifiquei a atuação dos historiadores mediante posicionamentos contrários à versão apresentada e proposições de encaminhamentos para alterações do documento. Perante o campo de conflito, surgiu as perguntas: qual o conhecimento selecionado como relevante nos documentos curriculares da disciplina de História? Como se justifica essa escolha? Como a seleção do conhecimento no componente curricular de História, na BNCC, dialoga com as disputas presentes no campo do Ensino de História desde a década de 1990 ?

As discussões sobre o conhecimento histórico curricular foram realizadas nas audiências e as propostas de mudanças foram encaminhadas ao CNE, mas até então não tínhamos como avançar na pesquisa até a aprovação da versão final do documento. Após a realização das audiências públicas, o documento seguiu para aprovação pelo Conselho Pleno do CNE, em outubro de 2017, e foi encaminhado para homologação pelo Ministério da Educação (MEC), em dezembro do mesmo ano.

A homologação do documento possibilitou definir o objeto da pesquisa, porém a versão final da Base foi encaminhada para aprovação sem as questões referentes ao Ensino Médio, segmento tratado à parte e finalizado somente em 2018. Tendo em vista a indecisão em relação à aprovação do documento por completo, optamos por analisar o conhecimento histórico curricular dos anos finais do Ensino Fundamental, e a escolha pelo componente de História se deu pelo interesse e atuação na área, como já exposto.

Uma vez delimitado o objeto da pesquisa, escolhemos a História Social do Currículo como pressuposto teórico, ao considerar o conhecimento curricular como construção social que expressa as escolhas de sujeitos sociais envolvidos na elaboração do currículo.

\footnotetext{
${ }^{1}$ Neste relatório, disciplina, componente e componente curricular são usados como sinônimos.

2 Ao longo do texto, o mesmo documento também é referido como "Base".
} 
A escolha cultural, que permeia o processo de elaboração curricular, torna-se campo de estudo na Educação e encontra na História Social contributos teóricos e metodológicos para uma história social do currículo. Entre esses contributos, destacam-se a partir das preocupações da História Social inglesa: a ação humana como constructo social; a superação da perspectiva determinista; a contextualização dos processos históricos; a diversidade dos sujeitos históricos, para além da figura do Estado; a problematização do lugar social e das práticas sociais; a variedade das evidências históricas, e, consequentemente, das metodologias de investigação histórica.

A concepção de currículo adotada na pesquisa dialoga com as ideias defendidas por Goodson (1997, 2006, 2008) e Sacristán (1998, 2000), para quem o debate curricular supera a dicotomia entre currículo escrito e currículo praticado, desenvolvendo-se em relações complexas que envolvem múltiplos processos, agentes e espaços. Goodson (2008) também ressalta a importância dos estudos curriculares nos vários níveis e áreas nos quais são produzidos, negociados e reproduzidos. $\mathrm{O}$ autor define o processo curricular em fase pré-ativa de currículo - que se refere à elaboração do currículo escrito - e fase interativa de currículo na qual se desenvolve o currículo real. Para o autor, o currículo escrito deve ser compreendido através de parâmetros anteriores à prática, no processo de identificação das lutas precedentes em torno da definição pré-ativa de currículo.

Sacristán e Gómez (1998) expandem as etapas de construção do currículo para além do currículo pré-ativo e interativo. Argumentam que se trata de um processo de confluência de práticas, na qual o documento escrito - o currículo prescrito que define o conteúdo que deve ser ensinado - interage com os diferentes sujeitos, em todas as etapas do processo. Os autores classificam essas etapas em: currículo planejado, currículo em ação, currículo realizado e currículo avaliado. Assim, definem o currículo como

[...] um objeto que se constrói no processo de configuração, implantação, concretização e expressão de determinadas práticas pedagógicas e em sua própria avaliação, como resultado das diversas intervenções que nele se operam (SACRISTÁN e GÓMEZ, 1998, p. 99).

A pesquisa escolhe como objeto de investigação o currículo prescrito pela BNCC do Ensino Fundamental - anos finais, em seu processo final de formulação e homologação. Ciente de sua complexidade e de seu caráter processual, entendemos que o documento curricular presente expressa o conhecimento considerado relevante, selecionado para ser ensinado nas escolas em um dado contexto. Tal seleção, em detrimento do conhecimento que não foi nela contemplada, evidencia o campo de disputa em torno das questões curriculares 
implícitas. A escolha do conhecimento dá voz aos anseios de alguns grupos, podendo silenciar e mesmo distorcer a voz de outros.

Também nos amparamos nas reflexões sobre a função da escola e o tipo de cidadão que pretende formar, lançadas por Michael Young (2007), ao questionar "Para que servem as escolas?”. Segundo o autor, a escola tem como finalidade primeira e fundamental, ensinar o conhecimento especializado, ao qual o aluno dificilmente terá acesso em espaços não escolares. O movimento para a construção de um currículo engajado, para o autor, é centrado na natureza do conhecimento das disciplinas, por meio dos conjuntos de conceitos estruturantes. Nesse aspecto, o estudo da disciplina de História, cerne da pesquisa, é discutido pelos seguintes movimentos: a relação entre conhecimento acadêmico e cultura escolar (CHARLOT, 2000; FORQUIN, 1993); as interfaces entre o conhecimento histórico acadêmico e escolar no campo da Educação Histórica (LEE, 2001; ASHBY, 2003); e por fim, a escolha teórica por um currículo organizado pela natureza do conhecimento histórico (LEE, 2016).

A defesa do conhecimento da disciplina de História se integra às preocupações dos estudos de Educação Histórica desenvolvidos por Lee (2001, 2003, 2008, 2016), Ashby (2003), Barton (2001) e Barca (2000, 2004, 2006). Esses autores indicam princípios, a partir dos conceitos de segunda ordem - conhecimento da natureza histórica -, que promovem, articulados aos conteúdos históricos, a progressão do pensar historicamente em sala de aula. Para esse fim, o currículo escolar deve contemplar a compreensão da História como uma disciplina e o entendimento da natureza da investigação histórica.

Mediante as reflexões teóricas, o objetivo geral assumido pela presente pesquisa foi compreender o processo de definição do conhecimento selecionado como relevante nos documentos curriculares da disciplina de História. A esse objetivo geral, articulam-se os seguintes objetivos específicos: analisar o debate sobre o conhecimento histórico presente nos currículos escolares sob as orientações anteriores à BNCC; identificar as disputas em torno da definição do conhecimento de História a ser ensinado no Ensino Fundamental - anos finais, durante o processo de elaboração da BNCC; e, por fim, identificar e discutir o conhecimento considerado relevante para o Ensino de História expresso na versão final da Base.

Por se tratar das questões do tempo presente, ainda não há um número expressivo de produções acadêmicas em relação à versão homologada da BNCC, na interface com as questões do currículo de História, como evidenciamos a seguir.

Inicialmente, foi realizada uma busca por trabalhos acadêmicos com o objetivo de identificar produções sobre as prescrições curriculares para a disciplina de História anteriores 
e posteriores ao processo de produção da $\mathrm{BNCC}$, de modo a ressaltar a relevância do tema da pesquisa desenvolvida. O levantamento foi realizado nas plataformas da Biblioteca Digital Brasileira de Teses e Dissertações (BDTD) e Plataforma Scielo, efetuando-se a busca pela palavra-chave "Ensino de História e Currículo". Nesse momento, consideramos os trabalhos publicados entre os anos 2000 a 2017, que tinham como objeto de pesquisa o currículo prescrito para o Ensino de História no Ensino Fundamental - anos finais.

Localizamos 14 trabalhos, os quais dividimos, para fins de apresentação, em dois quadros. O primeiro quadro reúne as produções que tratam do currículo prescrito de forma geral, e foi denominado "Produção acadêmica: Conhecimento/Conteúdo no Currículo Prescrito Oficial". E o segundo quadro trata de temas específicos do currículo prescrito para o Ensino de História, tendo sido denominado "Produção acadêmica: Diversidade Cultural, Patrimônio Cultural e História Regional".

O Quadro 1 é composto por sete trabalhos (seis artigos e uma tese) que tratam do currículo prescrito para a disciplina de História, seja o produzido pela esfera federal, tais como os Parâmetros Curriculares Nacionais (PCNs) e Diretrizes Curriculares Nacionais (DCNs), sejam as propostas curriculares produzidos pelas esferas estaduais e municipais.

Quadro 1 - Produção acadêmica: Conhecimento/Conteúdo no Currículo Prescrito Oficial

\begin{tabular}{|c|c|c|c|c|}
\hline $\begin{array}{l}\text { Tipo de } \\
\text { producão }\end{array}$ & Título & Autores & $\begin{array}{l}\text { Universidade/ } \\
\text { Periódicos }\end{array}$ & Ano \\
\hline Artigo & $\begin{array}{l}\text { Discutindo o currículo } \\
\text { "por } \\
\text { contribuições da pesquisa } \\
\text { etnográfica }\end{array}$ & $\begin{array}{l}\text { SCHMIDT; } \\
\text { GARCIA }\end{array}$ & Educar em Revista & 2001 \\
\hline Artigo & $\begin{array}{l}\text { Reformando o Ensino de } \\
\text { História: lições de } \\
\text { continuidade. }\end{array}$ & RODRIGUES & História (São Paulo) & 2004 \\
\hline Artigo & $\begin{array}{l}\text { O currículo bandeirante: a } \\
\text { Proposta Curricular de } \\
\text { História no estado de São } \\
\text { Paulo, } 2008 .\end{array}$ & $\begin{array}{l}\text { CIAMPI; } \\
\text { GODOY; } \\
\text { PIANELLI; } \\
\text { ALMEIDA } \\
\text { NETO; SILVA }\end{array}$ & $\begin{array}{lll}\text { Revista } & \text { Brasileira de } \\
\text { História } & & \end{array}$ & 2009 \\
\hline Tese & $\begin{array}{l}\text { Currículo e Ensino de } \\
\text { História em uma escola } \\
\text { da rede municipal de São } \\
\text { Paulo: entre prescrições e } \\
\text { práticas. }\end{array}$ & $\begin{array}{l}\text { CARVALHO } \\
\text { FILHO }\end{array}$ & $\begin{array}{l}\text { Universidade de São } \\
\text { Paulo }\end{array}$ & 2015 \\
\hline Artigo & $\begin{array}{l}\text { A História a ser ensinada } \\
\text { em São Paulo. }\end{array}$ & $\begin{array}{l}\text { ALMEIDA } \\
\text { NETO; } \\
\text { CIAMPI }\end{array}$ & Educação em Revista & 2015 \\
\hline Artigo & $\begin{array}{lc}\text { Literacia histórica } & \text { e } \\
\text { história transformativa }\end{array}$ & LEE & Educar em Revista & 2016 \\
\hline
\end{tabular}




\begin{tabular}{|l|l|l|l|l|}
\hline Artigo & $\begin{array}{l}\text { Competência ro do } \\
\text { pensamento histórico, } \\
\text { domínio de um panorama } \\
\text { histórico } \\
\text { conhecimento do cânone } \\
\text { histórico? }\end{array}$ & BORRIES & Educar em Revista & 2016 \\
\hline
\end{tabular}

Esses trabalhos apontam as transformações ocorridas no Ensino de História, em três contextos, a partir da década de 1990. O primeiro contexto, promovido pela legislação educacional, reformulada a partir da Carta Magna de 1988 e que resultou na Lei de Diretrizes e Bases da Educação (LDB), de 1996 e nos Parâmetros Curriculares Nacionais (PCNs), de 1997, que se assumem como parâmetros para guiar a produção de propostas curriculares no Brasil. O segundo, provindo da organização dos historiadores em torno da Associação Nacional de História (ANPUH), que a partir da década de 1980, toma como objeto de reflexão a pesquisa atrelada ao Ensino de História, culminando na organização de eventos e na publicação de pesquisas acerca da temática (DIAS, 2001). Tais iniciativas mobilizaram historiadores de todo o Brasil no enfrentamento de debates sobre as escolhas teóricas e metodológicas para o Ensino de História no período da ditadura militar. Por fim, o terceiro contexto reúne as pesquisas que ressaltam a influência dos movimentos sociais na busca por representatividade de diversos segmentos sociais nas políticas culturais e educacionais. Esse impulso resultou, por exemplo, na homologação da lei $n^{\circ}$ 10.639/2003, que torna obrigatório o Ensino de História e Cultura africana e afro-brasileira nos currículos escolares brasileiros - e posteriormente na lei $\mathrm{n}^{\mathrm{o}} 11.645 / 2008$, que inclui os conhecimentos relativos às culturas indígenas. As pesquisas evidenciam que esses três cenários de mudança curricular coexistiram, marcando em alguma medida, a produção dos documentos curriculares voltados para a disciplina de História, a partir da década de 1990.

As produções constantes do Quadro 1 identificam as transformações do currículo prescrito para o Ensino de História no período anterior à BNCC. Assim, Carvalho Filho (2015) analisa a relação entre o currículo prescrito e o currículo praticado nas escolas de São Paulo. Em sua pesquisa, aprecia as propostas curriculares para o Ensino de História no âmbito local do estado de São Paulo, mas considera-as na conexão com as orientações nacionais. Dessa forma, buscou elementos para compreender o que é considerado como conhecimento essencial de História, no currículo prescrito, e concluiu que

A tendência à diversidade está presente nas propostas curriculares mais recentes, herança da produção historiográfica dos anos 1980, particularmente dos historiadores vinculados à História Social ou à Nova História, que se caracterizam por ordenar o discurso histórico a partir dos problemas postos 
pelo presente. Nesse sentido, a compreensão do presente se articula aos 'recortes do passado' selecionados a partir de contextos determinados pela dinâmica social (CARVALHO FILHO, 2015, p. 21).

Carvalho Filho (2015) ainda destaca que os PCNs apontam que o conhecimento histórico a ser ensinado na escola deve partir das experiências dos diversos sujeitos históricos - entre eles, aqueles que foram excluídos da análise dos processos históricos da historiografia tradicional: mulheres, crianças, negros, índios, trabalhadores, entre outros.

Todos os demais trabalhos alocados no Quadro 1 tratam de reformas curriculares nas quais, em relação ao Ensino de História, se evidencia: o surgimento de novos temas, para além da História política; a construção do conhecimento histórico a partir da ampliação da noção de evidência histórica, rompendo com a limitada visão positivista de documento histórico; e a possibilidade da construção de um conhecimento histórico que não seja linear, evolucionista e eurocentrista.

As análises dos currículos prescritos no campo teórico ressaltam as mudanças descritas acima e seguem dois caminhos. O primeiro afirma que as mudanças propostas nos currículos prescritos não são verificáveis em plenitude nos currículos praticados nas escolas (CARVALHO FILHO, 2015; ALMEIDA NETO, 2015; CIAMPI, 2009; SCHMIDT,2001; RODRIGUES, 2004). Constituindo o segundo caminho, representado pelos trabalhos de Lee (2016) e Borries (2016), está a análise das mudanças no campo epistemológico do conhecimento histórico escolar, expressas nos currículos para o Ensino de História da década de 1990. Ambos os autores apontam fragilidades e sugerem reflexões curriculares na perspectiva da Educação Histórica e formação da consciência histórica.

Lee (2016) afirma que as questões da Educação Histórica, por vezes, estão vulneráveis às agendas políticas e educacionais curriculares ou reduzidas à promoção da cidadania e ao cultivo dos valores patrióticos. Para o autor, a Educação Histórica envolve questões mais complexas, situadas no campo da tradição metacognitiva do conhecimento, orientada pelos conceitos de segunda ordem. Sugere a inclusão do conceito de "Literacia Histórica" para a construção do conhecimento histórico, na defesa de

Uma compreensão disciplinar da história, como a aquisição das disposições que derivam e impulsionam essa compreensão histórica e como o desenvolvimento de uma imagem do passado, que permite que os alunos se orientem no tempo (LEE, 2016, p. 120). 
Diante do exposto, o autor questiona o lugar da história nos currículos escolares e a importância de sua natureza transformativa, capaz de modificar nossa visão sobre o presente e o futuro e produzir uma nova percepção do conhecimento sobre o passado.

Borries (2016, p. 171), por sua vez, faz críticas aos modelos curriculares para o Ensino de História, ao identificar o uso exclusivo da narrativa cronológica para as explicações históricas. O autor propõe o conhecimento histórico escolar como "um modelo de pensamento", e sugere, para o ensino da disciplina, a construção de competências do pensamento histórico, deslocando-se para a construção de um currículo que "poderia ir no sentido de explorar processos de mudança, eventos específicos de importância crítica para estudantes e pesquisas metodológicas".

Os demais trabalhos (três artigos e quatro dissertações) identificados no levantamento abordam o conhecimento histórico na perspectiva da diversidade cultural, do patrimônio cultural e da história local, e emergem em resposta às orientações assumidas nos PCNs e na lei ${ }^{\circ} 10.639 / 2003$. Eles estão reunidos no Quadro 2. 
Quadro 2 - Produção acadêmica: Diversidade Cultural, Patrimônio Cultural e História Regional

\begin{tabular}{|c|c|c|c|c|c|}
\hline $\begin{array}{c}\text { Tipo de } \\
\text { produção }\end{array}$ & Tema & Título & Autores & \begin{tabular}{|c|} 
Universidade/ \\
Periódicos
\end{tabular} & Ano \\
\hline Artigo & $\begin{array}{l}\text { Diversidade } \\
\text { cultural }\end{array}$ & $\begin{array}{l}\text { Ensino de História } \\
\text { e } \quad \text { diversidade } \\
\text { cultural: desafios e } \\
\text { possibilidades }\end{array}$ & FERNANDES & $\begin{array}{l}\text { Cadernos } \\
\text { CEDES }\end{array}$ & 2005 \\
\hline Artigo & $\begin{array}{l}\text { Patrimônio } \\
\text { cultural }\end{array}$ & \begin{tabular}{|lr} 
Currículo & de \\
História & $\mathrm{e}$ \\
educação para & o \\
patrimônio & \\
\end{tabular} & MATTOZZI & $\begin{array}{l}\text { Educação em } \\
\text { Revista }\end{array}$ & 2008 \\
\hline Dissertação & $\begin{array}{l}\text { História } \\
\text { local }\end{array}$ & $\begin{array}{l}\text { A Prática Docente } \\
\text { Do Professor De } \\
\text { História: Um } \\
\text { Estudo Sobre O } \\
\text { Ensino de História } \\
\text { Do Paraná Nas } \\
\text { Escolas Estaduais } \\
\text { De Londrina. }\end{array}$ & STECA & $\begin{array}{l}\text { Universidade } \\
\text { Estadual de } \\
\text { Londrina }\end{array}$ & 2008 \\
\hline Dissertação & $\begin{array}{l}\text { Diversidade } \\
\text { cultural }\end{array}$ & $\begin{array}{l}\text { História E Cultura } \\
\text { Afro-Brasileiras } \\
\text { No Currículo De } \\
\text { História Do } 6^{\circ} \text { Ao } \\
9^{\circ} \text { Anos, Da Rede } \\
\text { Oficial Do Estado } \\
\text { De São Paulo. }\end{array}$ & PONCIANO & \begin{tabular}{|ll}
\multicolumn{2}{|l|}{ Universidade } \\
do & Oeste \\
Paulista &
\end{tabular} & 2011 \\
\hline Dissertação & $\begin{array}{l}\text { Diversidade } \\
\text { cultural }\end{array}$ & $\begin{array}{lrr}\text { Quem } & \text { São } & \text { Os } \\
\text { Povos } & \text { Indígenas } \\
\text { Para } & & \text { Os } \\
\text { Estudantes? } & \\
\text { Reflexões } & \text { sobre O } \\
\text { Currículo } & \text { Básico } \\
\text { Comum } & \text { Do } \\
\text { Estado } & \text { De } & \text { Minas } \\
\text { Gerais. } & \\
\end{array}$ & GILAVERTE & $\begin{array}{l}\text { Universidade } \\
\text { Federal de São } \\
\text { Carlos }\end{array}$ & 2014 \\
\hline Dissertação & $\begin{array}{l}\text { Patrimônio } \\
\text { cultural }\end{array}$ & $\begin{array}{l}\text { Arquiteturas } \\
\text { temporais: a } \\
\text { prática } \\
\text { historiográfica do } \\
\text { patrimônio } \\
\text { cultural }\end{array}$ & CAVALCANTE & $\begin{array}{l}\text { Universidade } \\
\text { de Brasília }\end{array}$ & 2016 \\
\hline Artigo & $\begin{array}{l}\text { Diversidade } \\
\text { cultural }\end{array}$ & 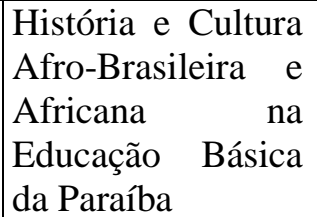 & CHAGAS & $\begin{array}{l}\text { Educação } \\
\text { Realidade }\end{array}$ & 2017 \\
\hline
\end{tabular}

O levantamento apresentado nos Quadros 1 e 2 tem o objetivo de identificar a produção acadêmica voltada aos estudos sobre os currículos prescritos para a disciplina de História nas duas últimas décadas, todos construídos sob a força orientadora dos PCNs. Daí, podemos destacar que o conhecimento histórico escolar nesse período foi influenciado pelas 
mudanças historiográficas da disciplina acadêmica, que resultaram na ampliação das abordagens temáticas para o Ensino de História. Isso se expressa na relevância atribuída aos diversos sujeitos históricos e na utilização de evidências históricas de variadas tipologias. Além disso, cumpre reconhecer o notório esforço empreendido no campo para abandonar perspectivas evolucionistas, lineares e eurocêntricas em relação ao conhecimento histórico escolar.

Após identificarmos os trabalhos que discutiram as propostas curriculares anteriores à $\mathrm{BNCC}$, redefinimos o recorte temporal para destacarmos pesquisas que focalizaram o currículo prescrito para a disciplina, já sob o impacto deste documento federal ou do seu processo de elaboração. São estudos publicados entre 2015 e 2018. Dessa forma, realizamos um segundo levantamento da produção científica sobre o tema, realizado na plataforma da Biblioteca Digital Brasileira de Teses e Dissertações (BDTD), com a busca pela palavra-chave "Base Nacional Comum Curricular". 3

Diante da grande quantidade de trabalhos apontados na categoria "Todos os campos", com 52 resultados, refinamos por assunto, dos quais escolhemos: "Base Nacional Comum Curricular" e "Currículo Prescrito". Fez-se necessário o refinamento para delimitar os trabalhos que têm como objeto de pesquisa a BNCC, já que no levantamento realizado, 52 resultados fazem referência ao documento para elaboração de currículos, práticas da docência, sugestão de temas e componentes para a versão em elaboração. No refinamento são indicados os seguintes trabalhos (cinco dissertações e quatro teses) que constam no Quadro 3.

\footnotetext{
3 A busca pela palavra-chave foi realizada em duas bases de dados: o banco de teses e dissertações da Coordenação de Aperfeiçoamento de Pessoal de Nível Superior (CAPES) e a BDTD. Comparando o resultado de ambas, escolhemos a segunda plataforma, por se mostrar mais completa e atualizada em relação à primeira.
} 
Quadro 3 - Currículo e Base Nacional Comum Curricular - BNCC

\begin{tabular}{|c|c|c|c|c|}
\hline $\begin{array}{c}\text { Tipo de } \\
\text { producão }\end{array}$ & Título & Autores & $\begin{array}{l}\text { Universidade/ } \\
\text { Periódicos }\end{array}$ & Ano \\
\hline Dissertação & $\begin{array}{l}\text { A Base Nacional } \\
\text { Comum Curricular em } \\
\text { questão. }\end{array}$ & RODRIGUES & $\begin{array}{l}\text { Pontifícia } \\
\text { Universidade } \\
\text { Católica de São Paulo }\end{array}$ & 2016 \\
\hline Dissertação & $\begin{array}{l}\text { Base Nacional Comum } \\
\text { Curricular } \\
\text { micropolítica: } \\
\text { analisando os fios } \\
\text { condutores. }\end{array}$ & ROCHA & $\begin{array}{l}\text { Universidade Federal } \\
\text { da Paraíba }\end{array}$ & 2016 \\
\hline Tese & $\begin{array}{l}\text { Identidades } \\
\text { amazônicas, saberes e } \\
\text { currículo das escolas de } \\
\text { Ensino Fundamental } \\
\text { em Parintins-AM. }\end{array}$ & $\begin{array}{l}\text { MARTINS } \\
\text { SILVA }\end{array}$ & $\begin{array}{l}\text { Universidade Federal } \\
\text { do Amazonas }\end{array}$ & 2016 \\
\hline Tese & $\begin{array}{l}\text { Currículo de } \text { História } \\
\text { no Ensino Médio e } \\
\text { avaliação de egressos: } \\
\text { a relação entre os } \\
\text { documentos } \\
\text { orientadores }\end{array}$ & $\begin{array}{l}\text { MARINS } \\
\text { FREIRE }\end{array}$ & $\begin{array}{l}\text { Universidade de São } \\
\text { Paulo }\end{array}$ & 2016 \\
\hline Dissertação & $\begin{array}{lr}\text { Desafios para a } \\
\text { implementação da Base } \\
\text { Nacional } & \text { Comum } \\
\text { Curricular. } & \end{array}$ & $\begin{array}{ll}\text { NAKAD } & \text { e } \\
\text { SKAF } & \end{array}$ & $\begin{array}{ll}\text { Fundação } & \text { Getúlio } \\
\text { Vargas } & \end{array}$ & 2017 \\
\hline Dissertação & $\begin{array}{lr}\text { Contribuição à crítica } \\
\text { da Base Nacional } \\
\text { Comum Curricular }- \text { a } \\
\text { máscara ra } \\
\text { conformismo } \\
\text { educação do na } \\
\text { Mundial. }\end{array}$ & HELENO & $\begin{array}{l}\text { Universidade } \\
\text { Estadual de Feira de } \\
\text { Santana }\end{array}$ & 2017 \\
\hline Tese & $\begin{array}{l}\text { Práticas corporais de } \\
\text { aventura: construção } \\
\text { coletiva de um material } \\
\text { didático digital. }\end{array}$ & TAHARA & $\begin{array}{l}\text { Universidade } \\
\text { Estadual Paulista }\end{array}$ & 2017 \\
\hline Dissertação & $\begin{array}{l}\text { Ensino de Geociências } \\
\text { na Educação Básica: } \\
\text { uma análise dos planos } \\
\text { de estudos de uma rede } \\
\text { municipal de ensino. }\end{array}$ & $\begin{array}{l}\text { SILVA } \\
\end{array}$ & $\begin{array}{l}\text { Centro Universitário } \\
\text { UNIVATES, Lajeado }\end{array}$ & 2017 \\
\hline Tese & $\begin{array}{l}\text { O ensino da Geografia } \\
\text { e sua especificidade na } \\
\text { Base Nacional Comum } \\
\text { Curricular brasileira: } \\
\text { uma cartografia das } \\
\text { ausências. }\end{array}$ & OZÓRIO & $\begin{array}{l}\text { Pontifícia } \\
\text { Universidade } \\
\text { Católica de São Paulo }\end{array}$ & 2018 \\
\hline
\end{tabular}


Quatro autores constantes do Quadro 3 possuem em comum a BNCC como objeto de pesquisa, mas em perspectivas diferentes (RODRIGUES, 2016; NAKAD \& SKAF, 2017; ROCHA, 2016; HELENO, 2017).

Rodrigues (2016) analisa o processo de construção da BNCC entre os anos de 2015 e 2016, através da análise comparada das duas primeiras versões do documento, no que se refere à parte introdutória, que apresenta os fundamentos do texto. A pesquisa salienta que o processo de elaboração não foi tão democrático e participativo como afirmam o governo vigente à época e seus apoiadores.

Heleno (2017) também tem como objeto de pesquisa a BNCC e seu processo de construção e, tal como Rodrigues (2016), analisa o contexto de desenvolvimento e debate das versões iniciais, e avança um pouco no processo de elaboração da terceira versão, que ainda não havia sido homologada. $\mathrm{O}$ autor analisa a articulação entre as políticas públicas educacionais e as teorias do conhecimento, trabalhando com as seguintes categorias: política para o novo milênio, cidadania e direitos de aprendizagem e desenvolvimento. Assim, conclui que os elaboradores da Base justificam as escolhas curriculares a partir das exigências internacionais do Banco Mundial (BM), denunciando um esvaziamento teórico da categoria de cidadania, o que poderia resultar em uma educação propensa a consolidar uma postura de conformismo. A pesquisa torna-se relevante ao articular os sujeitos diretamente envolvidos com a elaboração do documento às instituições educacionais privadas e ligadas diretamente às políticas educacionais neoliberais.

Rocha (2016) também discute o processo de construção da BNCC, no recorte da segunda versão. Mas, diferentemente dos demais, analisa o documento no contexto da prática dos professores da educação básica na Paraíba. Nesse contexto, a pesquisadora conclui que a participação dos docentes não foi garantida no processo de elaboração do documento, dessa forma, não se tratou de um processo democraticamente participativo.

As três pesquisas apresentadas são relevantes ao problematizarem o processo de elaboração da Base em suas versões preliminares, negando o alegado caráter democrático e participativo afirmado pelo MEC. A tese que ora se apresenta também buscou trazer elementos nesse mesmo sentido, ao analisar o processo final de elaboração e homologação da BNCC. Por exemplo, encontra-se aqui afinidade com as vozes daqueles que se opuseram à homologação da terceira versão e realizaram o pedido de vistas do processo - as Conselheiras do Conselho Nacional de Educação (CNE) Aurina de Oliveira Santana, Malvina Tania Tuttman e Marcia Ângela da Silva Aguiar - e das associações de profissionais - Associação Nacional de Pós-Graduação e Pesquisa em Educação (ANPEd), Associação Brasileira de 
História (ANPUH), Associação Brasileira de Currículo (ABdC) -, que alegaram que as considerações sobre o documento, realizadas nas audiências públicas, não foram levadas em conta na elaboração da versão final.

Nakad e Skaf (2017), responsáveis pela quarta e última produção constante do Quadro 3, que tem como objeto de pesquisa a BNCC, ao contrário das demais, não discutem o processo de elaboração e produção do documento. Tem como propósito principal elaborar recomendações de ação para uma política pública de implementação da BNCC, antes mesmo da homologação do documento pelo CNE. A pesquisa propõe estratégias para implementação, a partir das dificuldades elencadas pelo Movimento Todos Pela Base Nacional Comum ${ }^{4}$, sobrepondo as posições dos segmentos reunidos nesse Movimento às dos responsáveis pela condução do processo de legitimação do documento, tais como o MEC e CNE - ou, assumindo que se tratam das mesmas perspectivas.

As demais pesquisas tratam da BNCC na perspectiva de disciplinas específicas. São estudos que abordam as disciplinas - Geografia (OZÓRIO, 2018) e História (MARINS, 2016) - e temas, tais como: identidades amazonenses (MARTINS, 2016), geociências (SILVA, 2017) e práticas corporais de aventura (TAHARA, 2017), que são tratadas em documentos curriculares: PCNs, DCN e também na BNCC. A problemática escolhida para essas investigações é o lugar da disciplina ou do tema no currículo escolar. Destacaremos a seguir as discussões das propostas curriculares das disciplinas de Geografia e História, que se aproximam do que se pretendeu desenvolver na pesquisa que originou a presente tese.

Em relação ao currículo da disciplina de Geografia, Ozório (2018) analisa a versão final da BNCC e conclui que o ensino de Geografia proposto não é renovado e nem engajado. A pesquisa sinaliza o que reconhece como uma desvalorização do componente curricular, bem como das outras áreas das ciências humanas, no documento.

Em relação à disciplina de História, Marins (2016) analisa o seu currículo a partir de uma perspectiva histórica, ressaltando a legislação curricular vigente até 2013. No levantamento da produção científica, essa foi a única pesquisa que focalizou especificamente

\footnotetext{
${ }^{4}$ O Movimento Todos Pela Base Nacional Comum Curricular tem como membros fundantes pessoas ligadas às fundações Santillana, Lemann e Instituto Unibanco e se define como um "grupo não governamental e apartidário de pessoas, organizações e entidades que desde 2013 se dedica à causa da construção e implementação da BNCC e do Novo Ensino Médio". Entretanto, em seus quadros identificamos professores das universidades e da educação básica, gestores dos setores públicos e privados, conselheiros de educação, deputados federais e organizações não governamentais interessados na oferta da educação privada, formação de professores e elaboração de materiais didáticos. Estes últimos, em parceria com os grupos empresariais ligados à Fundação Roberto Marinho, Consed, Instituto Ayrton Senna, Todos Pela Educação, Undime e outros. Os grupos sociais, as entidades e as organizações elencadas tiveram forte protagonismo nas audiências públicas para a construção do documento final da Base. Disponível em: http://movimentopelabase.org.br/quem-somos/
} 
o componente curricular de História. Entretanto, o estudo apenas sinaliza a importância dos conhecimentos curriculares da disciplina para fundamentar a elaboração de uma base nacional comum curricular que ainda seria construída. Dessa forma, esta tese, em alguma medida, dá continuidade a essa discussão, agora na perspectiva da atual versão da BNCC.

Diante do levantamento inicial da produção, anterior e posterior à homologação da BNCC, identificou-se mudanças no conhecimento histórico escolar, fruto das reformas curriculares realizadas na década de 1990. As produções apresentadas nos Quadros 1 e 2 acenam de forma positiva para a inserção de novas abordagens temáticas, associadas à preocupação com a diversidade e influenciada pelas correntes historiográficas da História Social e Nova História, além da ampliação da noção de evidência histórica - construção do conhecimento histórico para além das abordagens do tempo linear, cronológico, evolucionista e eurocentrista.

Sinalizadas as mudanças no conhecimento histórico curricular segundo os autores das obras produzidas entre os anos de 2000 a 2017, tornou-se preocupação da investigação se tais transformações irão permanecer ou não na nova proposta de reforma curricular na qual se enquadram as discussões da Base. Isso porque nas audiências públicas de colaboração ao documento curricular, os historiadores se posicionaram de forma crítica ao documento e encaminharam novas proposições. Diante desse contexto, inquirimos sobre quais as perspectivas dos profissionais da Educação e dos historiadores em relação aos conhecimentos históricos que deveriam ser abordados nas escolas e por quê.

O segundo levantamento sobre a Base Nacional Comum Curricular e o Currículo Prescrito, apresentado no Quadro 3, aponta apenas uma produção que tem como objeto de pesquisa o componente curricular de História, mas que não tem como objeto de análise a versão final da Base. Permanece, assim, a lacuna em relação a quais conhecimentos históricos foram defendidos como essenciais no documento final do componente curricular de História. Quais vozes foram ouvidas e quais foram silenciadas no documento prescrito?

Assim, no desenvolvimento da pesquisa que resultou nesta tese, identificamos lacunas na produção no que se refere às mudanças e permanências do conhecimento histórico nos currículos escolares anteriores à BNCC, no seu processo de elaboração e na versão final do documento.

Para o desenvolvimento da tese, redirecionamos o levantamento inicial das produções acadêmicas sobre "Ensino de História e Currículo". A nova busca possibilitou selecionar pesquisas que analisaram os documentos curriculares de História produzidos na 
década de 90, e, mediante a análise bibliográfica, identificamos rupturas e continuidades no processo de seleção do conhecimento histórico para compor o currículo escolar.

A análise documental dos ofícios encaminhados ao Conselho Nacional de Educação (CNE) nos permitiu identificar as propostas para o Ensino de História, e comparar com o que se propunha antes da BNCC, na triangulação com o resultado obtido pela análise bibliográfica anterior.

Com os resultados da triangulação, relacionamos as posições defendidas na versão final da BNCC, no trecho que se refere ao Ensino Fundamental - anos finais, com os posicionamentos manifestados nas audiências e nos documentos encaminhados ao CNE na tramitação deste documento. Esses posicionamentos possibilitaram compreender as disputas em torno do campo curricular de História, de modo a identificar as vozes silenciadas e as expressas na BNCC, comparando-as com o que se expressava no contexto anterior.

A tese foi estruturada da seguinte maneira: no primeiro momento apresentamos e justificamos as escolhas teóricas e metodológicas da pesquisa. Iniciamos com a identificação da noção de currículo e de conhecimento escolar. Em seguida, abordamos os princípios da Educação Histórica e a relação com o conhecimento histórico escolar. Concluímos, então, com os aspectos metodológicos da pesquisa.

No segundo momento apresentamos e discutimos os resultados obtidos. As análises foram realizadas segundo três enfoques próprios de contextos específicos: anterior à BNCC, de elaboração da BNCC e por fim, de apresentação da versão final da BNCC.

Nas considerações finais, retomamos a pergunta inicial e relacionamos com os frutos da pesquisa, a fim de mapearmos o caminho traçado e ressaltarmos questões relevantes para o debate sobre o conhecimento histórico no currículo escolar, apontando as potencialidades e limitações do estudo. 


\section{ESCOLHAS TEÓRICAS E METODOLÓGICAS}

Neste capítulo, apresentamos e justificamos as escolhas teóricas e metodológicas da pesquisa. Iniciamos com a identificação das noções de currículo e de conhecimento escolar, amparadas nos pressupostos da História Social do Currículo. Em um segundo momento, abordamos os aspectos do conhecimento histórico a partir da relação entre conhecimento acadêmico e cultura escolar; e as interfaces entre os conhecimentos históricos acadêmicos e escolares, tratadas pelo campo da Educação Histórica. Em seguida, apresentamos os princípios do currículo organizado pela natureza do conhecimento histórico. Concluímos, assim, com a apresentação dos aspectos metodológicos da pesquisa.

\subsection{FUNDAMENTAÇÃO TEÓRICA}

O presente trabalho não tem como objetivo definir e conceituar o currículo e nem produzir uma história linear e evolucionista sobre o campo. Discutiremos o currículo como uma construção social que se define nas dimensões histórica e sociológica, problematizando-o em sua característica de processo.

Propor ou analisar a construção histórica e social do currículo é compreender, acima de tudo, em que consiste uma História Social. Para Hobsbawm (1998, p. 84), o termo História Social é de difícil e complexa definição, mas ele já foi associado às seguintes questões, temas e abordagens: a) sujeitos históricos ligados às classes trabalhadoras e aos movimentos sociais; b) assuntos decorrentes das diversas atividades humanas, tais como práticas cotidianas, usos e costumes - não apenas restritas às camadas mais pobres -; e, por fim, c) abordagens do "social" combinadas com a "história econômica".

A ampliação do tema e da abordagem para além do aspecto econômico foi possível, segundo Hobsbawm (1998, p. 86), pela historicização geral das ciências sociais, ocorrida nas décadas de 1960 e 1970. Segundo o autor, o contexto histórico de revoluções e processos de lutas pela independência política e econômica de países coloniais e semicoloniais, provocou a atenção de governos, organizações internacionais e de pesquisa e, consequentemente, os cientistas sociais passaram a atentar para o que são, essencialmente, problemas de transformações históricas. Resulta daí, segundo o autor, a "convergência de trabalhos de diferentes disciplinas para problemas sócio-históricos" (HOBSBAWM, 1998, p. 88). Nessa abordagem, em torno da qual convergem pesquisadores de diferentes áreas

preocupados com os problemas das transformações históricas, podemos identificar a articulação entre as áreas da História, Sociologia e Educação, na perspectiva da construção 
social do currículo, e, também, a ruptura dessas ciências com as explicações deterministas e de cunho economicista.

Essa articulação disciplinar, desenvolvida no contexto da década de 1970, resulta da preocupação com a construção social do currículo, especialmente no âmbito da Nova Sociologia da Educação (NSE) e da História Social do Currículo, respectivamente, a tradição sociológica representada, entre outros, por Michael Young - elemento central do movimento da NSE-, e a tradição histórica de Ivor Goodson - denominada História do Currículo e das Disciplinas Escolares.

Ambas as abordagens, de orientação inglesa, consideram o currículo como construção social e histórica, e rompem com a perspectiva do currículo como fato dado e naturalizado e, para isso, propõem a crítica sociológica e histórica das escolhas curriculares operadas no tempo.

A perspectiva sócio-histórica do currículo considera os movimentos dos agentes/sujeitos históricos nos contextos internos e externos à escola, busca identificar processos de permanências/estabilidades e rupturas, e analisa categorias construídas historicamente, tais como: tradição, verdade e conhecimento. Categorias essas consideradas necessárias para compreender os movimentos de reformas curriculares, seja da década de 1970 ou da contemporaneidade.

Na história social do currículo é importante perceber que o reconhecimento da relação entre conhecimento e poder é antiga, porém ainda é necessário reafirmá-la. Ela foi enfatizada desde a década de 1970 pela NSE e também nos Estados Unidos, no movimento de reconceitualização do campo. Nessa lógica, compreende-se que o currículo expressa uma seleção cultural, questiona-se quem faz essa seleção, identificam-se pressões sobre esse processo de seleção, associadas ao contexto internacional e nacional, e ressaltam-se os interesses envolvidos nesse processo de construção e seleção do que deve ser ensinado nas escolas.

\subsubsection{Currículo}

Ao estudar a História Social do Currículo, faz-se necessário identificar a diversidade de concepções de currículo em jogo e, consequentemente, as configurações da função da escola associadas a cada uma dessas concepções.

Nos estudos curriculares, a definição unívoca do termo currículo é apontada como um caminho inviável. Teóricos sinalizam a inviabilidade da definição pela própria transformação que ocorre no campo teórico dos estudos curriculares, principalmente os que 
compreendem o currículo como uma construção social, na qual sua significação estará condicionada ao contexto de produção, não se esquivando dos movimentos de rupturas e permanências dos processos históricos.

Nessa perspectiva, Silva (2014, p. 14) afirma que o currículo é um movimento histórico no qual "uma determinada teoria pensa o que o currículo é”. Para o autor, a definição de currículo é particularmente histórica, ao se apoiar em pistas sobre "como, em diferentes momentos, em diferentes teorias, o currículo tem sido definido" (SILVA, 2014, p. 14). Conclui que, apesar da existência das diversas teorias do currículo (tradicionais, críticas e póscríticas), as questões permanentes a todas são: qual conhecimento deve ser ensinado para garantir a formação do cidadão que se busca em um dado contexto, e por quê?

Pacheco (2005, p. 38) também sinaliza a dificuldade em definir currículo, e alerta que qualquer tentativa de fazê-lo é um caminho para além da definição, "é algo que nos levará à identificação de contextos, actores e intenções". Dessa forma, o autor corrobora também com a abordagem histórica da noção de currículo.

Para os teóricos do currículo, a dificuldade em defini-lo não é um problema para o campo dos estudos curriculares. Segundo Sacristán e Gómez (1998, p. 126), a polissemia do conceito atribui riqueza à noção, pois o constante processo de construção conceitual possibilita perceber diferentes perspectivas da realidade. Eles argumentam que:

Em primeiro lugar, se o currículo faz alusão aos conteúdos do projeto educativo e do ensino, a imprecisão provém da própria amplitude desses conteúdos, já que ensinar, num sistema escolar tão complexo e prolongado para os alunos/as, engloba níveis e modalidades que cumprem funções em partes semelhantes e em parte muito distintas - a escolarização cumpre fins diversos. Em segundo lugar, esses fins educativos tendem a se diversificar ou se traduzir em projetos educativos que implicam interpretações diferentes das finalidades educativas (1998, p. 126).

Para os autores, a noção de currículo está diretamente relacionada à permanente preocupação com o conteúdo do ensino e com as finalidades da educação, bem como com o contexto no qual é construído e desenvolvido, por agentes e interesses específicos que lhe conferem, assim, características peculiares, conforme também ressalta Pacheco (2005, p. 38). É essa diversidade de conteúdos, agentes, contextos e interesses educacionais que possibilitam compreender diferentes perspectivas da realidade que, consequentemente, ampliam e renovam o campo dos estudos curriculares.

O diálogo com os autores da teoria curricular possibilitou situar as preocupações curriculares na pesquisa desenvolvida. No caso das permanências em relação à noção de currículo, a pesquisa tem como objeto de investigação o conhecimento, questão geral que 
fundamenta as preocupações do campo, e no caso específico do estudo, o conhecimento histórico escolar.

A partir das reflexões da teoria curricular, buscamos identificar as justificativas para o conhecimento apontado como relevante nos documentos curriculares de História e, consequentemente, a definição de qual conhecimento não o é. Dessa forma, a pesquisa focalizou alguns dos agentes produtores do currículo e o contexto de elaboração, na tentativa de reconhecer os interesses em disputa e de discutir as preocupações ligadas ao papel assumido para a escola e ao tipo de cidadão que se deseja formar.

Após compreender as questões centrais para os estudos curriculares orientados no que ensinar e na finalidade do que se ensina, seguimos os estudos teóricos com objetivo de identificar e localizar os vários níveis e áreas nos quais é produzido, negociado e reproduzido o currículo. Sobre esses níveis, Goodson (2008) sugere o fim da dicotomia entre currículo escrito - nível da elaboração do documento curricular - e currículo prático - nível do desenvolvimento do currículo, nas escolas e salas de aula -, geralmente analisados de forma isolada, e sendo usualmente o segundo mais enfatizado do que o primeiro.

$\mathrm{O}$ autor divide o processo curricular em fase pré-ativa de currículo - que se refere à elaboração do currículo escrito - e fase interativa de currículo - na qual se desenvolve o currículo real. Aponta uma área de articulação curricular na fase pré-ativa do currículo, que antecede e se integra à fase interativa. Nessa perspectiva, o currículo escrito deve ser compreendido através de parâmetros anteriores à prática, no processo de identificação das lutas precedentes em torno da definição pré-ativa de currículo, já que

o currículo escrito nos proporciona um testemunho, uma fonte documental, um mapa do terreno sujeito a modificações; constitui também um dos melhores roteiros oficiais para a estrutura institucionalizada da escolarização (GOODSON, 2008, p. 22).

Para o autor, a compreensão da etapa pré-ativa de um currículo escrito possibilitará a problematização curricular ao "aumentar o nosso entendimento dos interesses e influências atuantes nesse nível” e por permitir "conhecer melhor tanto os valores e objetivos patenteados na escolarização quanto a forma como a definição pré-ativa pode estabelecer parâmetros para ação e negociação interativa no ambiente da sala de aula da própria escola" (GOODSON, 2008, p. 24).

Sacristán (2000) também salienta a necessária quebra da dicotomia entre currículo escrito e realizado, ao compreender o currículo como confluência de diversas práticas, em diferentes contextos. Para ele, o currículo é composto por níveis que integram o processo 
curricular - prescrito, planejado, organizado, em ação e avaliado - que não devem ser hierarquizados (SACRISTÁN e GÓMEZ, 1998, p. 139). Esses níveis, ou dimensões, “atuam convergentemente na definição da prática pedagógica com poder distinto e através de mecanismos peculiares em cada caso" (SACRISTÁN, 2000, p. 101). Dessa forma, o autor entende o currículo em sua dimensão processual, promovendo a sua análise segundo a identificação e integração dos diversos níveis e âmbitos nos quais ele se desenvolve. Os níveis são convergentes e devem ser analisados de forma processual e integral, em contextos de formulação, transformação e desenvolvimento curriculares. Nesse sentido, o currículo "pode ser visto como um objeto que cria em torno de si campos de ação diversos, nos quais múltiplos agentes e forças se expressam em sua configuração, incidindo sobre aspectos distintos" (SACRISTÁN, 2000, p. 101).

Ciente da complexidade do conceito de currículo, a pesquisa aqui apresentada propõe uma análise que incide sobre o contexto de formulação curricular, no qual se concebe o currículo prescrito. Definindo-o como instância na qual se dá a produção do documento curricular, evidencia-se que é nesse lugar que se estabelece um primeiro recorte cultural do que deverá ser ensinado na escola. O contexto de elaboração curricular constitui um âmbito de decisões epistemológicas, políticas e administrativas, externas à escola.

A pesquisa desenvolvida operou no âmbito do currículo no contexto da elaboração e, a partir dos estudos teóricos, compreendemos a necessidade de identificar: primeiro, os movimentos dos agentes/sujeitos históricos nos contextos internos e externos à escola - isto foi essencial para identificar os agentes produtores do currículo, entre eles, sujeitos que atuam nas diversas esferas do Estado, as comunidades acadêmicas e os empresários educacionais; e segundo, os processos de permanências/estabilidades e rupturas operadas na seleção do conhecimento histórico expresso nos documentos curriculares em contexto de formulação.

O aprofundamento dos caminhos escolhidos acima contou com a reflexão sobre o currículo prescrito como expressão da política curricular. Sobre isso, Sacristán (2000, p. 109) chama atenção que

ao estabelecer concretamente os mínimos para todo o sistema educativo ou para algum de seus níveis, [o currículo prescrito] cumpre diferentes funções que é preciso esclarecer para dar a esta fase de decisões seu justo valor e analisar as consequências de expressar as prescrições dessa ou daquela forma. 
Nesse contexto, o autor sugere cinco aspectos que devem ser observados na política curricular e que auxiliam no processo de análise do currículo prescrito como campo de ação - não necessariamente pedagógica, mas com poder de enquadrar a prática de ensino. Um deles, que é discutido nesta tese, diz respeito às "formas de regular ou impor uma determinada distribuição do conhecimento dentro de um sistema educativo" (SACRISTÁN, 2000, p. 110). Mas, em coerência com a perspectiva processual, admite-se que outros aspectos apontados pelo autor, tais como: a estrutura de decisões na regulamentação e no controle do currículo; os aspectos sobre os quais o controle incide; e os mecanismos de controle sobre a prática e as políticas como estratégias de melhoria do ensino, não devem ser ignorados nos estudos curriculares.

Nesta investigação analisamos a BNCC, tomando-a como o currículo prescrito que se reveste de uma intencionalidade voltada ao estabelecimento de um currículo comum e, consequentemente, da pretensão de uma escola também comum em alguma medida. A análise do currículo prescrito, segundo Sacristán (2000), possibilita caracterizar o campo de disputas entre os agentes produtores do currículo. Nesse sentido, considera-se que

na decisão de que cultura se define como mínima e obrigatória está se expressando o tipo de normatização cultural que a escola propõe aos indivíduos, a cultura e o conhecimento considerado valioso, os padrões pelos quais todos serão, de alguma forma, avaliados e medidos, expressando depois para a sociedade o valor que alcançaram nesse processo de normalização cultural (SACRISTÁN, 2000, p. 112).

$\mathrm{Na}$ perspectiva adotada neste estudo, o currículo prescrito é considerado revelador, por expressar o conhecimento que se escolheu num dado momento e numa dada configuração de poder para responder ao que se entende como a função social da escola. Sobre isso, Young (2007, p. 1295) destaca que as questões centrais sobre o currículo devem ser pautadas na diferenciação do conhecimento entre o conhecimento escolar e não escolar:

A ideia de que a escola é primordialmente um agente de transmissão cultural ou de conhecimento nos leva a perguntar "qual conhecimento?" e, em particular, questiona que tipo de conhecimento é responsabilidade da escola transmitir. Sendo aceito que as escolas têm esse papel, fica implícito que os tipos de conhecimento são diferenciados. Em outras palavras, para fins educacionais, alguns tipos de conhecimentos são mais valiosos que outros, e as diferenças formam a base para a diferenciação entre o conhecimento curricular ou escolar e conhecimento não-escolar. Existe algo no conhecimento escolar ou curricular que possibilita a aquisição de alguns tipos de conhecimento. Portanto, minha resposta à pergunta "Para que servem as escolas?" é que elas capacitam ou podem capacitar jovens a adquirir o conhecimento que, para a maioria deles, não pode ser adquirido em casa ou em sua comunidade, e para adultos, em seus locais de trabalho. 
Michael Young $(2007,2011)$ é um defensor do currículo centrado no conhecimento da disciplina. Por esse posicionamento, é facilmente confundido com os defensores das disciplinas na perspectiva dita "tradicional", que consideram o saber disciplinar como inquestionável, naturalizado e descontextualizado. A defesa do saber da disciplina realizada por Young (2007) considera que o conhecimento produzido pela ciência ensinada é capaz de fomentar o questionamento sobre a realidade vivida. O autor se refere ao conhecimento capaz de "fornecer explicações confiáveis ou novas formas de se pensar a respeito do mundo" (YOUNG, 2007, p. 1294). Defende, assim, um currículo engajado e potente, transformador das formas de compreensão da realidade, diferentemente do currículo de acatamento, no qual o conhecimento disciplinar não tem função questionadora da sociedade, mas sim de legitimação do status quo.

Dessa forma, a pergunta "qual a função da escola?" precede a definição do conhecimento a ser ensinado e, para Young, bem como para Goodson, os fatores econômico e político são fortes influenciadores nas reformas curriculares, buscando responder a essas perguntas. Na Inglaterra, por exemplo, em um contexto recente, Young (2007, p. 1290) identifica uma "tentativa de adequar os resultados das escolas ao que é tido como 'as necessidades da economia', numa espécie de vocacionalismo em massa”.

Buscando exemplos dessas influências sobre as definições curriculares no Brasil, encontra-se em Barretto (1998) um panorama das reformas curriculares ocorridas nas décadas de 80 e 90, período marcado pela redemocratização do país. A autora pontua os paradigmas educacionais internacionais, nos quais a educação toma para si responsabilidades nos campos políticos, econômicos e sociais, resultando em preocupações curriculares para a manutenção dos governos democráticos. Isso se expressa de forma especial nos países da América Latina, pela proliferação de discursos que buscam, por meio da escola, a superação das desvantagens na inserção do indivíduo no mercado de trabalho competitivo, o combate à desigualdade social e redução da violência, bem como o respeito às diferenças. Toda essa responsabilização da educação, põe a escola na difícil missão de resolução dos problemas sociais:

A ideia da educação como "toda poderosa" e mola privilegiada da transformação social deixa, contudo, de colocar em evidência o peso relativo da educação, uma vez que fatores de ordem econômica, cultural, política e outros podem ter igual ou maior efetividade do que ela para desencadear as mudanças pretensamente desejadas (BARRETTO, 1998, p. 21).

A responsabilização da escola por questões que estão fora do seu alcance, legitima o constante discurso de crise da educação e as inúmeras reformas curriculares para atender 
aos anseios econômicos e políticos da contemporaneidade. Isto posto, cabe lembrar a reflexão sobre para que servem as escolas, e qual conhecimento deve ser ensinado. Além disso, vale compreender que o argumento da crise educacional e as pretensões das reformas curriculares, em nome de uma educação de qualidade, fazem parte de um campo de disputa e devem ser analisados com suspeição. Todo desejo de mudança deve ser examinado e minimamente ponderado. Como sugere Goodson (2006, p. 26), nem toda mudança tem caráter progressista.

Em momentos difíceis, quando as forças globais estão estimulando a reestratificação e a rediferenciação, a mudança pode ter um lado muito pouco desejável. Com isso, os teóricos e defensores da mudança precisam pelo menos examinar as "estruturas de oportunidade" em que sua mudança irá exercer seu efeito. Pois, se não levarem a cabo essa investigação, poderiam estar promovendo mudanças que têm efeitos bem diferentes que possam estar desejando. A mudança, longe de ser progressista, poderia ter o efeito oposto.

O olhar atento ao caráter das reformas curriculares pode evidenciar as intencionalidades que estão em jogo. A reforma que envolve a BNCC, homologada em 2017 e em processo acelerado de implementação - através da elaboração das propostas curriculares estaduais e municipais, e em articulação com os programas de produção de material didático e de formação de professores -, é definida como urgente e justificada por um contexto de "crise" educacional, diante da qual se propõe a solucionar os problemas que impedem a concretização de uma educação de qualidade, atendendo às exigências ligadas à avaliação e aos interesses do mercado econômico. Diante da crise alegada, quais conhecimentos são eleitos para compor o currículo, e o que tem para oferecer o conhecimento histórico nesse contexto de produção curricular, justificado pelo imediatismo das questões do tempo presente e de ordem econômica?

Para Lee (2016, p. 111), o lugar da história no currículo, nos últimos anos, segue dois caminhos: o primeiro, que atende uma agenda política e econômica ou, quando não, um segundo, que está a serviço de um ideal de nacionalismo e patriotismo. O resultado da primeira direção é a valorização de habilidades genéricas; no segundo caminho, a integração muitas vezes ligeira das experiências cotidianas ao conhecimento escolar. Diante da conclusão de Lee (2016), inquirimos o que haveria de valioso no conhecimento histórico escolar que poderia superar os resultados limitantes dos caminhos apontados?

Anterior a essa preocupação, a pesquisa desenvolvida ocupa-se em identificar quais conhecimentos históricos foram selecionados nos documentos curriculares e quais as permanências e rupturas manifestas no campo da formulação curricular de História nas últimas três décadas. A partir de tais achados, a pesquisa pretende contribuir apontando 
potencialidades e fragilidades para a escolha do conhecimento histórico escolar manifesto nos documentos curriculares. Dessa forma, seguiremos o debate teórico, articulando as questões referentes ao campo do currículo às do conhecimento e, em específico, do conhecimento da disciplina de História.

\subsubsection{Conhecimento histórico}

A História Social do Currículo possibilita compreender as aproximações e distanciamentos entre a ciência de referência e a disciplina escolar, construída em uma perspectiva histórica e em um constante processo de definição, ao considerar que essa articulação é "complexa e não pode ser entendida como um processo mecânico e linear, pelo qual o que se produz enquanto conhecimento acadêmico seja (ou deva ser) necessariamente transmitido e incorporado pela escola" (BITTENCOURT, 2004, p. 49).

O conhecimento histórico presente nos documentos curriculares é cerne da pesquisa desenvolvida, e cabe aqui explicarmos as bases que sustentam tal noção. Longe de tomá-la como um dado pré-definido, o faremos pelos seguintes movimentos: a relação entre o conhecimento acadêmico e a cultura escolar; as especificidades e interfaces entre o conhecimento histórico acadêmico e o conhecimento histórico escolar por meio do campo da Educação Histórica; e por fim, um caminho para a organização curricular centrada na natureza do conhecimento histórico.

O conhecimento histórico acadêmico "se refere genericamente ao processo de construção do conhecimento definido pelos padrões da ciência moderna que têm a universidade como instituição de referência para a sua afirmação" (KNAUSS, 2019, p. 47). Dessa forma, o conhecimento acadêmico, no caso histórico, é produzido pela comunidade acadêmica, definida enquanto produção historiográfica e classificada em diversas correntes teóricas, que ora se opõem ora se complementam. Assim, o conhecimento histórico escolar tem como referência o conhecimento histórico produzido pela historiografia e, por vezes, por mais de uma de suas correntes.

Uma visão reducionista dessa relação classifica o conhecimento escolar como mera reprodução do conhecimento acadêmico, desconsiderando seu espaço e contexto de produção e circulação. Tal perspectiva passou a ser superada pelo movimento de diferenciação dos conhecimentos, ao considerar que o conhecimento acadêmico é transposto para o espaço escolar através do processo didático, mediado pelo docente.

Forquin (1993, p. 14) afirma que toda educação de tipo escolar necessita de uma seleção e transposição dos conteúdos da cultura. A partir dos estudos proponentes da 
transposição didática (VERRET, 1975; CHEVALLARD, 1985) ${ }^{5}$, o autor estabelece a relação intrínseca entre seleção cultural, transmissão e transposição didática, ao afirmar que

a educação escolar não se limita a fazer uma seleção entre os saberes e os materiais culturais disponíveis num dado momento, ela deve também, para torná-los efetivamente transmissíveis, efetivamente assimiláveis às jovens gerações, entregar-se a um imenso trabalho de reorganização, de reestruturação ou de "transposição didática" (1993, p. 16).

Esse processo de deslocamento do conhecimento especializado para os fins a que se dedica a escola pode resultar na ênfase em dicotomias, a partir da valorização e hierarquização entre ditos saberes teóricos e outros saberes de diferentes naturezas, especialmente de ordem prática: aprendemos a teoria na universidade, e a prática, aprendemos na escola. Para Charlot (2000, p. 62) a dicotomia estabelecida entre saberes teóricos e práticos é um erro, pois o que está em jogo é a relação com o conhecimento, "é a relação com esse saber que é 'científica' ou 'prática' e, não esse saber em si mesmo”. Dessa forma, a hierarquização dos conhecimentos por tal diferenciação é infundada.

Superada e abandonada a errônea dicotomia teórico/prático, os críticos da ideia considerada instrumentalista e mecânica da transposição didática chamam atenção para a necessidade da distinção dos conhecimentos através dos pontos de interseções e especificidades. Evidenciando a autonomia do trabalho escolar e as configurações específicas da cultura escolar, Forquin (1993, p. 17) destaca:

Se o imperativo da "transposição didática" impõe a emergência de configurações cognitivas específicas (os saberes e os modos de pensamento tipicamente escolares), estas configurações tendem a escapar de seu estatuto puramente funcional de instrumento pedagógico e de auxiliares das aprendizagens, para se constituir numa espécie de "cultura escolar" sui generis, dotada de sua dinâmica própria e capaz de sair dos limites da escola para imprimir sua marca "didática" e "acadêmica" a toda espécie de outras atividades (que intervêm por exemplo no contexto dos lazeres, dos jogos, do turismo, no campo político ou no campo profissional), sustentando assim com as outras dinâmicas culturais (com as diferentes expressões da cultura "erudita", com as diferentes formas da cultura dita "popular", com os meios de comunicação de massa, com as práticas cognitivas ou as maneiras próprias de alguns grupos) relações complexas e sempre determinadas, de nenhum modo redutíveis, em todo caso, aos processos de simples reflexos ou de "repartição de tarefas".

\footnotetext{
${ }^{5}$ Referência das obras utilizadas por Forquin (1993): CHEVALLARD, Y. La transposition didactique; du savoir savant au savoir enseigné, Grenoble, La Pensée Sauvage, 1985. VERRET, M. Le temps des études, Lille, Atelier de reproduction des thèses, 2 vol, 1975.
} 
Segundo o autor, o que acontece é mais do que a constituição de um reflexo do conhecimento acadêmico na escola; o processo de reelaboração do conhecimento deve atender às especificidades da cultura escolar e garantir a base didática e acadêmica nas atividades desenvolvidas. Partindo dessa ideia, estabelecemos a relação entre currículo e cultura escolar, considerando que o trabalho desenvolvido na escola envolve uma seleção cultural educativa, manifesta nas diversas dimensões curriculares, - no caso da pesquisa desenvolvida, no currículo em fase de formulação, o currículo prescrito.

Em outros termos, Sacristán e Gómez (1998, p. 128) afirmam que "a cultura selecionada e organizada dentro do currículo não é a cultura em si mesma, mas a versão escolarizada em particular". Daí, decorre nossa compreensão de que o conhecimento histórico presente no currículo não é a ciência histórica produzida pela historiografia, tal qual em seus objetivos, mas a cultura histórica em suas bases didáticas e acadêmicas. Essa relação culturaconteúdos curriculares manifesta no "texto, que é o currículo, não responde às intenções de ser reprodutor do que entendemos por cultura fora da escola, mas [...] é uma cultura própria que tem certas finalidades intrinsecamente escolares e que presta, naturalmente, um peculiar serviço à socialização e à reprodução" (SACRISTÁN e GÓMEZ, 1998, p. 128).

Sacristán e Gómez (1998) e Goodson (1997) sinalizam que a formulação do texto curricular e a sua implementação se dão pela intervenção de agentes diversos. A seleção cultural curricular passa pelo crivo de grupos com interesses diversos, em disputas que envolvem a comunidade disciplinar, o Ministério da Educação (que representa o Estado e suas demais esferas administrativas), grupos empresariais, entre outros. Goodson (1997) afirma que é preocupação comum entre os agentes elaboradores do currículo a procura por recursos materiais e simbólicos, construindo, assim, relações diretas com o plano econômico. Com base nisso, o autor estabelece a relação intrínseca entre disciplinas escolares e processo político mais amplo, a partir da divisão dos agentes produtores do currículo em missões disciplinares e missões burocráticas.

O primeiro tipo refere-se ao conhecimento produzido pela comunidade disciplinar. Tais missões são "representadas por indivíduos, grupos, segmentos e facções" e, na escola (ou fora dela), têm o foco nas disciplinas, ou seja, consistem em "promover a disciplina conquistando os grupos legítimos com vista de apoio ideológico e recursos" (GOODSON, 1997, p. 44), assim garantindo a sua manutenção e permanência no currículo.

O segundo tipo, as missões burocráticas, se assentam no aparelho burocrático do Estado, e se relacionam com a base econômica representada pela "cultura empresarial", que desempenha a "administração e definição das categorias institucionais do ensino" 
(GOODSON, 1997, p. 50). A disputa ocorre no campo político, mediante a aliança entre a burocracia estatal (que define e administra as categorias institucionais) e os grupos externos (que fornecem apoio ideológico e recursos ao Estado). Esse alinhamento "cria uma estrutura contextual para a compreensão das missões dos grupos disciplinares" (GOODSON, 1997, p. $52)$.

Esse autor desperta atenção para os interesses diferentes que estão em jogo na escolha do conhecimento disciplinar expresso nos documentos curriculares. Compreendemos, a partir das reflexões apresentadas, que a definição do conhecimento histórico escolar manifesto no documento prescrito parte dos grupos disciplinares, mas está em constante negociação e disputa com os interesses de grupos externos e da burocracia estatal, que não podem ser negligenciados.

No campo de missão disciplinar, abordada por Goodson (1997), inquirimos a comunidade disciplinar de História para identificar qual a justificativa para a inclusão e manutenção da disciplina de História no currículo escolar. Qual conhecimento histórico é considerado valioso e, desta forma, selecionado para ser ensinado? Como se justificam essas escolhas? Quais as especificidades e interfaces estabelecidas entre o conhecimento histórico acadêmico e conhecimento histórico escolar?

Inquirir a comunidade disciplinar de História com base em um referencial teórico supõe, certamente, fazer escolhas. Diante das diferentes abordagens no campo do Ensino de História, escolhemos realizar essa reflexão teórica segundo a perspectiva da Educação Histórica.

A escolha pelo campo da Educação Histórica se deu pelo seu comprometimento com as questões relacionadas à epistemologia e à didática da disciplina. Dessa forma, não buscamos definir o conhecimento histórico escolar, mas compreender de que forma a Educação Histórica, através da epistemologia da História, visa possibilitar que os alunos na escola possam aprender o conhecimento histórico. Para esse fim, o currículo deve promover as escolhas pelos conhecimentos que favorecerão a compreensão da História como uma disciplina, e o entendimento da natureza da investigação histórica (ASHBY, 2003, p.37).

O campo da Educação Histórica construído nos últimos 40 anos, ganhou amplitude e profundidade nas abordagens das pesquisas desenvolvidas a partir de 1990. As investigações produzidas na Inglaterra, Portugal, Canadá, Estados Unidos e Brasil, abordam ideias dos alunos e docentes em relação ao pensamento histórico. Recentemente, as pesquisas avançaram para as questões relacionadas aos espaços museológicos, a preservação dos patrimônios, os livros didáticos e currículo do Ensino de História, conforme é possível 
perceber pelas investigações apresentadas nas Jornadas Internacionais de Educação Histórica $^{6}$. É nesse âmbito que se insere a pesquisa ora desenvolvida, que visa contribuir para o alargamento da pesquisa em Educação Histórica no Brasil, no contexto das questões curriculares, que ainda são incipientes.

A pesquisa optou em ancorar as reflexões teóricas em relação à Educação Histórica a partir das preocupações de Peter Lee, fundador do campo na Inglaterra, durante a crise curricular de 1970. Lee (2001, p. 13), relata que, na época, o componente curricular de História era optativo e os alunos não apresentavam interesse pela disciplina, pois o conteúdo se distanciava das questões do conhecimento histórico e se aproximava de "estórias" fixas de um passado vazio de sentido para eles. Então o Projeto 13-16, coordenado por Denis Shemilt, teve o objetivo de ensinar História a partir da natureza histórica e, no contexto, "era necessário haver algo que as crianças aprendessem progressivamente, que se operassem mudanças de ideias e que elas conseguissem perceber as mudanças” (LEE, 2001, p. 14).

O projeto 13-16 ganhou ampla divulgação e execução nas escolas inglesas e possibilitou a Lee desenvolver o Projeto CHATA (Concepts of History and Teaching Approaches), que investigou as ideias das crianças sobre a narrativa em História. Os resultados dessa pesquisa alicerçam as discussões realizadas pelo autor no campo da compreensão histórica pelos alunos e o desenvolvimento de uma Literacia Histórica.

Para Lee (2008, p. 26), a Literacia Histórica está interligada com o que os alunos precisam saber em História. Consiste em uma ecologia temporal, capaz de proporcionar uma “compreensão disciplinar da história, uma compreensão histórica e o desenvolvimento de uma imagem do passado que permite aos alunos se orientarem no tempo" (LEE, 2016, p. 121). Para o autor, a questão “o que é que os alunos precisam saber?” não está tão clara nos currículos e programas de estudo. E alerta:

[...]Os alunos precisam desesperadamente compreender como o presente é o movimento principal do passado, não um qualquer momento instantâneo cortado pela "mudança" de tudo o que se procede. Os alunos também precisam saber que o conhecimento do passado é possível, que vale a pena avaliar as afirmações que as pessoas fizeram no passado e que embora nós nunca possamos ter uma única história definitiva, algumas respostas a

\footnotetext{
${ }^{6}$ A Jornada Internacional de Educação Histórica realizou sua vigésima edição em 2020, conforme sítio do evento. A lista de eixos temáticos contempla questões educacionais da contemporaneidade tais como: Currículo e Ensino da História; Temas sensíveis na História; Consciência histórica e Humanismo; Formação de Professores: inicial e contínua; Aprender e Ensinar na Era Digital e Concepções e Práticas em Educação Histórica. Os trabalhos apresentados ainda não foram publicados nas atas do evento. Disponível em: http://xxcongresso.mozello.com/
} 
algumas questões acerca do passado serão melhores do que outras (mais válidas e mais "verdadeiras") (LEE, 2008, p. 27).

Para Lee (2008, p. 12), os alunos iniciam o pensamento histórico a partir das ideias tácitas ou do senso comum, conhecimentos que constroem durante sua experiência na escola e fora dela, o que Barca (2006, p. 23) complementa, afirmando que "os conceitos tácitos e os argumentos dos alunos deverão construir o ponto de partida para a construção de aprendizagens".

Abud (2005, p. 27) também sinaliza o ponto de partida para construção do conhecimento histórico, ao afirmar que os alunos constroem processos analógicos de conhecimentos históricos que já conhecem, ou estabelecem "relação entre fatos do passado e do presente e não somente em relação a dois fatos do passado, próximos ou distantes”. Dessa forma, o processo de analogia a partir do conhecimento tácito do aluno é o ponto inicial para a compreensão histórica.

O conhecimento tácito do aluno opera com conceitos de "Verdade e Mudança", provenientes das práticas cotidianas e que não operam com a mesma complexidade conceitual que na disciplina de História. Nesse contexto, Lee (2003, p. 25) propõe uma progressão na compreensão dos conceitos históricos, que são oriundos do conhecimento tácito do aluno e ganham amplitude na compreensão histórica. Para isso, é necessário que o conhecimento histórico opere com a conexão entre os conceitos substantivos (informações factuais do passado) e os conceitos de segunda ordem (referentes ao processo de raciocínio e lógica histórica), alicerçados na compreensão da História como uma disciplina e no entendimento da natureza da investigação histórica.

Os conceitos substantivos da disciplina são "relacionados com o passado histórico" (BARCA, 2000, p. 16) e "se referem a conteúdos da História, como por exemplo o conceito de Indústria" (LEE, 2001, p. 20). Eles são desenvolvidos a partir dos temas do Ensino de História, no caso do exemplo, da Revolução Industrial.

Muitas propostas curriculares de História dão ênfase apenas aos conteúdos da História ou aos temas da História, ao indicar uma lista de conteúdos a serem ensinados e são, assim, classificadas de conteudistas. Lee (2008, p. 11) atenta que a compreensão substantiva e coerente do passado é necessária para construir "uma 'imagem' do passado que lhes permita orientarem-se no tempo". Então, a questão não é negligenciar os conteúdos históricos, mas escolhê-los a partir dos critérios epistemológicos da História, já que aprender um conjunto muito extenso de conhecimentos históricos substantivos não garante conhecer a natureza do conhecimento histórico. 
Uma saída na contramão dos documentos curriculares "conteudistas" é a articulação indissociável entre os conhecimentos substantivos e os conceitos de segunda ordem, os últimos "relacionados com a natureza da História-conhecimento, por ex., interpretação, explicação ou evidência" (BARCA, 2000, p. 16), o que, para Lee (2008, p. 11), é "um conhecimento de como sabemos, desenvolvendo uma explicação e narrativa histórica do passado".

Conforme exposto, a compreensão histórica se faz não apenas pelo conhecimento do conteúdo histórico, mas também pelo conhecimento da forma pela qual sabemos sobre o passado, a partir das suas categorias explicativas, próprias da natureza histórica, pois "mesmo quando os alunos têm um conhecimento de História substantivo e louvável, as suas perspectivas acerca da evidência histórica ou os seus conceitos tácitos de mudança podem tornar a História ininteligível e/ou sem utilidade” (LEE, 2008, p. 11).

As pesquisas desenvolvidas por Lee (2001), Barton (2001), Ashby (2003) e Barca (2004) analisam como os alunos pensam historicamente através da progressão do raciocínio histórico, de ideias simples à mais complexas, ao serem confrontados com a epistemologia da História em situações-problema. Segundo Ashby (2003, p. 51), “os professores podem trabalhar a partir das compreensões existentes (ideias tácitas) e contestar as ideias alternativas que impedem o progresso posterior”. Esse exercício de cognição consiste em diagnosticar o que e como os alunos sabem de História e, assim, elaborar situações problemas através da investigação histórica, para proporcionar o entendimento complexo dos conceitos da natureza histórica (Causa, Mudança, Evidência e Interpretação).

Para essa metodologia da cognição histórica, faz-se necessário o desenvolvimento de competências específicas de interpretação e compreensão do passado. Dessa forma, o campo desenvolve princípios, tipologias e estratégias para a cognição histórica que são operacionalizadas em sala de aula, por meio de didáticas específicas da História, mas que compreendemos que devem ser tratadas no currículo prescrito não só como orientações metodológicas, mas na própria seleção dos conhecimentos históricos que favorecerão as competências da cognição histórica no desenvolvimento do currículo em ação.

Ao investigar as competências da cognição histórica, Ashby (2003) e Barca (2004) evidenciaram a relação entre o conhecimento substantivo e o de segunda ordem, expressa no currículo inglês, implementado em 1999. Nesse sentido, Ashby (2003, p. 38) apresenta as cinco áreas-chave do currículo de História: “1. Compreensão cronológica; 2. Conhecimento e compressão de acontecimentos, povos e mudanças do passado; 3 . Interpretação histórica; 4. Investigação histórica e 5. Organização e comunicação". 
Barca (2004, p. 136) reitera os pontos acima e complementa a explicação das áreas 2 e 4, respectivamente no que se refere ao "conhecimento e compreensão de temas em âmbito de profundidade" e "pesquisa histórica e a interpretação das fontes", e à necessidade de ambos atuarem articulados através do desenvolvimento de conceitos-chave como causa, mudança, evidência e interpretação, por meio dos procedimentos da investigação histórica. Para Ashby (2003), essas exigências curriculares que mobilizam os conceitos históricos a partir da mobilização da História como disciplina têm implicações no ensino e avaliação dos alunos, já que

estes não aprendem apenas a regurgitar factos e pormenores históricos, mas têm de ser capazes de lhes dar significado e de os organizar em relação a outros, como explicações ou narrativas que envolvem mudança, desenvolvimento e continuidade. Também lhes é pedida a compreensão de como as particularidades de História são estabelecidas com base na evidência e de como a evidência é usada para construir narrativas e interpretações do passado (p. 38).

Dessa forma, não apenas o item dois, referente ao conhecimento substantivo, que deve ser objetivo do ensino e da avaliação: "o conhecimento substantivo é claramente um aspecto crucial desta avaliação, mas a sua ressignificação sem sentido não é suficiente" (ASHBY, 2003, p. 42). Ou seja, importa também conhecer os procedimentos da investigação histórica no componente curricular de História. Nesse contexto, o conceito de evidência, associado aos procedimentos da investigação histórica, assume centralidade para a compreensão histórica e a elaboração mais complexa do passado, permitindo que os conceitos tácitos dos alunos (Mudança, Causa, Narrativa) sejam elevados no grau de complexidade e de sentido na abordagem do passado e, assim, justificando a relevância da sua inserção no currículo de História.

Lee (2008) desenha um quadro explicativo de como algumas ideias tácitas dos alunos tornam a História contraintuitiva. O conhecimento do passado torna-se impossível quando é constituído sobre as bases de um conhecimento por familiaridade ou por um passado fixo. $\mathrm{O}$ autor explica que a ideia de um passado fixo é expressa no momento em que os alunos entendem que "as coisas aconteceram de uma só maneira e ninguém pode mudar isso, então só há uma descrição do passado verdadeira" (p. 16).

A segunda explicação de um passado impossível ocorre ao classificar o conhecimento do passado pelo conhecimento de familiaridades: "nós só podemos saber o que vemos" (LEE, 2008, p. 16). Ambas as explicações (passado fixo ou por familiaridade) tornam a história impossível, pois partem da premissa de que se "não estivemos lá, então não 
podemos saber". Desse modo, pensar historicamente é passar da história impossível, para a possível. Para isso, Lee (2008, p. 17) propõe o abandono da noção de fonte histórica como mero relato de um acontecimento, e o movimento de transição do conceito de "testemunho" para o conceito de "evidência histórica". Esse caminho torna-se possível quando as fontes históricas são analisadas a partir dos princípios da natureza histórica, interrogadas, verificadas a respeito da credibilidade em relação ao contexto de produção interna e externa e identificadas quanto à sua natureza, de modo a compreender que "as fontes só podem ser dignadas de válidas, ou não, no contexto do seu uso como evidência” (ASHBY, 2003, p. 50).

A problematização da evidência histórica a partir da investigação possibilitará compreender o passado e as diferentes narrativas históricas, ampliando, assim, a compreensão histórica dos alunos, de uma História impossível para possível, através da progressão do conceito de evidência. A progressão, nesse caso, não é a acumulação do conteúdo histórico, mas o desenvolvimento da narrativa a partir de ideias simples para mais sofisticadas. Lee (2008, p. 15) explica: “as ideias mais sofisticadas tornam a História possível pensando-a como uma atividade cognitiva genuína, enquanto as ideias menos sofisticadas destroem o valor da História".

O autor acima exemplifica a progressão de ideias acerca de como a História é possível da seguinte forma: o aluno compreende que a História está nos livros, então a História é possível. Nós não estávamos lá para saber o que aconteceu, então a História se torna impossível. Podemos nos basear nas evidências, então a História torna-se possível novamente. As evidências podem mentir ou enviesar o fato? A História é impossível novamente. Por fim, quando as narrativas históricas são construídas a partir das evidências e devem ser pensadas a partir da compreensão da natureza histórica, a História passa a ser possível. Dessa forma, a problematização da evidência pelo critério da natureza histórica torna possível a compreensão do saber histórico pela progressão, o que significa

equipar os alunos com ideias mais sofisticadas/poderosas, por exemplo
acerca de como nós podemos conhecer o passado e por que é que as
narrativas históricas dos historiadores diferem. Equipados com esse tipo de
ideias serão mais capazes de operar mais eficientemente com a história
substantiva (LEE, 2008, p. 19).

Segundo Barca (2006, p. 22), a explicação das diversas narrativas históricas, às vezes em versões divergentes, devem superar a explicação do senso comum, na qual "uma versão é melhor porque é a que mais me agrada e/ou todas as versões são iguais em valor, porque todas dependem de um determinado ponto de vista”. A Educação Histórica rompe 
com a explicação do senso comum e proporciona contributos para a educação social atual, na qual:

É preciso saber selecionar entre várias propostas e saber decidir a favor das melhores. Quando jovens e adultos são, cada vez mais, incitados pelos media a optar entre ideias ou entre produtos, a formação de uma opinião fundamental torna-se hoje de extrema relevância. Não para que todos escolham exatamente o mesmo, mas para que o façam com critérios de alguma qualidade e rigor. A educação histórica e social poderá ter um contributo neste campo, se proporcionar aos alunos o exercício gradualmente critico de abordagens de versões diferenciadas. Será esta - entendemos uma das muitas formas possíveis e válidas de ajudar os jovens a apropriarem-se cognitivamente do real (BARCA, 2006, p. 23).

Entende-se que a compreensão da evidência histórica possibilita identificar que "alguns alunos têm ideias mais poderosas que outros" e que "ideias mais poderosas possibilitam ao aluno resolver problemas que os que operam com ideias menos poderosas não conseguem resolver" (ASHBY, 2003, p. 43).

A Educação Histórica, na abordagem aqui explorada, atribui à disciplina de História o desenvolvimento das competências da natureza histórica, diferentes das competências genéricas orientadas pelas exigências do mercado de trabalho e que permeiam os currículos da contemporaneidade. As competências da disciplina promovem a habilidade de pensar historicamente e, com isso, localizar-se no mundo. Barca (2004, p. 134), afirma que ser competente em História significa desenvolver

uma compreensão contextualizada do passado, com base na evidência disponível, e pelo desenvolvimento de uma orientação temporal que se traduza na interiorização de relações entre o passado compreendido, o presente problematizado e o futuro perspectivado.

As competências em História exigem operações a partir da tríade de interpretação de fontes, compreensão contextualizada e comunicação. Destaca-se a progressão em relação à interpretação das fontes, que operam de ações mais simples para operações mais complexas, na seguinte proposta desenvolvida pela autora:

a) Saber ler diferentes fontes históricas, com suportes diversos (fotografia, pinturas, documentos escritos, depoimentos orais, cultura material); b) Saber selecionar fontes para confirmação ou refutação de hipóteses; c) Saber entender o nós (identidade) e os outros (alteridade) em diferentes tempos e espaços; d) Saber levantar novas hipóteses de investigação (BARCA, 2004, p. 134-135). 
As competências acima se alinham com a ideia da natureza transformativa da História, de Lee (2016, p. 130), ao alertar para o fato de que a História possibilita a modificação da nossa visão do presente e do futuro, pela problematização do passado em construção.

Lee (2016, p. 130) destaca que esse processo é progressivo e de longo prazo, não atendendo, assim, às reivindicações instrumentalistas de curto prazo de algumas políticas curriculares, nas quais o lugar da História no currículo passa a ser associado às habilidades generalistas, com a justificativa de promover uma "cidadania" e produzir resultados genéricos. Tais propostas instrumentais não favorecem o exercício do pensamento reflexivo, e se alinham a uma perspectiva de currículo de acatamento, na visão de Young (2011). Neste contexto, os currículos de História distanciam-se do conhecimento histórico disciplinar, esvaziam-se dos conceitos de segunda ordem do pensar histórico e centram-se nos conteúdos substantivos por si só, sem avançar para o pensamento relacional, impossibilitando o desenvolvimento de uma educação escolar que fortaleça a educação histórica e que nela se apoie para cumprir sua função social. 


\subsection{METODOLOGIA}

Neste item, apresentamos os aspectos metodológicos da pesquisa, que dividimos em três tópicos. No primeiro, apontamos o contexto da pesquisa, ao justificar a escolha do tema associado à pergunta central da investigação. Ainda, por meio da pergunta central, expomos e justificamos a escolha pela pesquisa qualitativa. O tópico prossegue com a identificação das fontes e procedimentos utilizados para responder às questões de investigação, por meio da explicação do caminho desenvolvido na produção e análise dos dados. No segundo tópico, que apresenta as fontes, discorremos sobre a coleta dos dados e a escolha dos documentos, justificados pelos objetivos da investigação. Por fim, no terceiro tópico, detalhamos os procedimentos e os instrumentos de análise dos dados.

\subsubsection{O contexto e o tipo da pesquisa}

A pesquisa foi concebida durante o processo de elaboração da BNCC, entre os meses de junho e setembro de 2017. Ao acompanhar as cinco audiências públicas, realizadas pelo Conselho Nacional de Educação (CNE), sobre a terceira versão do texto da BNCC, chamou nossa atenção o posicionamento dos historiadores em relação à versão apresentada. A ANPUH, representada pelos historiadores associados, manifestou-se contrária ao documento curricular e apresentou proposições para alteração da proposta. Perante a identificação do campo de conflito, inquirimos qual o conhecimento selecionado como relevante nos documentos curriculares da disciplina de História?

A pergunta investigativa nos aproximou da pesquisa qualitativa que, segundo Bogdan e Biklen (1994), tem como característica analisar a ação humana contextualizada, não se limitando, no caso de uma pesquisa documental, ao texto produzido, mas implicando a articulação ao contexto de sua produção. Dessa forma, analisamos a documentação a partir da identificação dos sujeitos e/ou instituições produtoras dos materiais, atrelando-os aos lugares sociais que ocupam. A articulação é fundamental para compreensão dos posicionamentos curriculares defendidos pelos propositores da BNCC, bem como os dos seus críticos. A abordagem contextualizada do objeto de estudo também visa evitar incorrer em explicações generalistas pouco relevantes para uma análise crítica.

Outra potencialidade da metodologia qualitativa é a de ser capaz de se afastar do caráter meramente descritivo dos dados. Estes são esmiuçados, interrogados e confrontados com outras fontes. O cruzamento entre dados de tipologias diferentes - por exemplo, nesta investigação, o confronto entre os ofícios encaminhados ao CNE e os vídeos das audiências públicas -, nos permite observar posicionamentos dos sujeitos proponentes do currículo, com 
formas de expressão e percepções diferentes. Gestos e vozes, nos registros em vídeo, possibilitam a interpretação documental com detalhes que escapariam à frieza do documento escrito, ou da mobilização de dados numéricos ou estatísticos. De fato, a análise dos detalhes nos gestos, nas palavras utilizadas, "exige que o mundo seja examinado com a ideia de que nada é trivial” (BOGDAN; BIKLEN, 1994, p. 49). Considerou-se, assim, que na perspectiva da construção social do currículo - entendido como campo de disputas e conflitos pela eleição do conhecimento que deve compor os documentos curriculares -, a análise descritiva e processual - características da pesquisa qualitativa -, viabilizam o alcance do inquérito da investigação.

A partir da questão central, assumimos a importância de (1) identificar as disputas em torno do conhecimento a ser selecionado para o Ensino de História durante o processo de elaboração da BNCC, bem como (2) reconhecer como elas se relacionam ao debate sobre esse tema em contextos anteriores à Base e, por fim, (3) reconhecer e discutir as permanências e mudanças nas escolhas curriculares no período em análise.

Por meio da análise documental dos ofícios e falas encaminhados e/ou produzidos pelo MEC, CNE, ANPUH e ANPEd buscamos atender ao objetivo 1, citado acima, reconhecendo as perspectivas dos profissionais da Educação e dos historiadores em relação aos conhecimentos que deverão ser abordados na escola, no contexto de produção da BNCC. Pela análise bibliográfica das produções acadêmicas sobre currículo e Ensino de História, publicadas no período de 2000 a 2017, buscamos atender ao objetivo 2, evidenciando o que era apontado como conhecimentos históricos relevantes no debate teórico desenvolvido em etapa anterior à BNCC, bem como as justificativas para essa seleção ou as críticas a ela. Em relação ao objetivo 3, a análise do Parecer CNE/CP n ${ }^{\circ}$ 15/2017 17 e da versão final da BNCC, no trecho que se refere ao Ensino Fundamental - anos finais, permitem relacionar as escolhas assumidas nestes textos com os posicionamentos manifestados nas audiências e nos documentos encaminhados ao CNE.

No caminho desenvolvido para a análise e triangulação dos dados, buscamos compreender as disputas em torno do campo curricular de História, com vistas a identificar as vozes silenciadas e as expressas na versão final da BNCC. A triangulação dos dados, realizamos a partir da comparação entre as análises de experiências curriculares anteriores à Base com os posicionamentos manifestados nas audiências e nos documentos encaminhados ao $\mathrm{CNE}$, bem como com as posições apresentadas no texto da Base.

As questões investigativas guiaram o levantamento de informações pertinentes, a produção e a análise dos dados, bem como a sua triangulação, de modo que, ao identificar as 
posições em disputa sobre o Ensino de História no processo de elaboração da BNCC, foi possível refletir sobre as raízes desse debate em período anterior a este documento.

\subsubsection{Os documentos}

Com base na análise das fontes documentais, a pesquisa buscou compreender qual o conhecimento selecionado como relevante nos documentos curriculares da disciplina de História, bem como as justificativas para essas escolhas e as posições divergentes. Dessa forma, os documentos foram selecionados e analisados com os seguintes objetivos: caracterizar o debate sobre o conhecimento histórico presente nos currículos escolares anteriores à homologação da BNCC; identificar as disputas em torno do componente curricular de História durante o seu processo de elaboração; e, por fim, reconhecer e discutir o conhecimento considerado relevante para o Ensino de História que foi expresso efetivamente na versão final do Base.

Para alcançar o primeiro objetivo, analisamos o levantamento da produção acadêmica sobre o currículo de História publicada em etapa anterior à BNCC (2000-2017). A identificação dos debates sobre o conhecimento histórico curricular nesse período é relevante, pois permitiu identificar mudanças e continuidades no debate teórico da área do Ensino de História, com possibilidade de reconhecer alterações no jogo de forças entre as diversas perspectivas curriculares para o ensino da disciplina.

Diante da consolidada produção acadêmica sobre currículo e Ensino de História, produzida no período de 2000 a 2017, decidimos focalizar apenas as produções que analisaram os documentos curriculares de História produzidos em período anterior à Base. $\mathrm{O}$ inventário do conhecimento produzido sobre currículo e Ensino de História em momento anterior à BNCC foi realizado através de levantamento que usou os descritores: "currículo" e "Ensino de História" e "Ensino Fundamental”, nos seguintes catálogos: Biblioteca Digital de Teses e Dissertações (BDTD), Banco de Dados Bibliográficos da USP (Dedalus) e Sistema Integrado de Bibliotecas da USP (SIBi).

A busca foi realizada nos sítios indicados e levou às seguintes produções: Sistema Integrado de Bibliotecas da USP (SIBi), com dois artigos (GONZALEZ, 2012; SILVA e SIQUELI, 2016); Biblioteca Digital de Teses e Dissertações (BDTD), com uma dissertação (MARIA, 2013); Banco de Dados Bibliográficos da USP (Dedalus), com três teses e uma dissertação (ROCHA, 2001a e 2001b; CARVALHO FILHO, 2015; GUIMARÃES, 2007).

Após a coleta e leitura do material, decidiu-se analisar as três teses e as duas dissertações, devido à profundidade da discussão em relação ao conhecimento histórico 
curricular nesses trabalhos e, também, pela quantidade dos documentos curriculares analisados pelos pesquisadores. Segue o quadro com as produções escolhidas.

\begin{tabular}{|c|c|c|c|c|}
\hline \multicolumn{5}{|c|}{ Quadro 4 - Produção acadêmica sobre currículo e Ensino de História } \\
\hline $\begin{array}{l}\text { Tipo } \\
\text { produção }\end{array}$ & Título & Autor & Universidade & Ano \\
\hline $\begin{array}{ll}\text { Tese } & \text { de } \\
\text { Doutorado } & \end{array}$ & $\begin{array}{l}\text { Identidades e Ensino de } \\
\text { História: um estudo em } \\
\text { escolas do Rio Grande } \\
\text { do Norte. }\end{array}$ & ROCHA & $\begin{array}{lr}\text { Faculdade } & \text { de } \\
\text { Educação } & \text { da } \\
\text { Universidade } & \text { de } \\
\text { São Paulo - FEUSP }\end{array}$ & $2001 \mathrm{a}$ \\
\hline $\begin{array}{ll}\text { Tese } & \text { de } \\
\text { Doutorado } & \end{array}$ & $\begin{array}{l}\text { Currículos de história } \\
\text { do Rio de Janeiro, } \\
\text { cotidiano escolar e } \\
\text { ensino: recuperando } \\
\text { 'elos perdidos'. }\end{array}$ & ROCHA & $\begin{array}{lr}\text { Faculdade } & \text { de } \\
\text { Educação } & \text { da } \\
\text { Universidade } & \text { de } \\
\text { São Paulo - FEUSP }\end{array}$ & $2001 b$ \\
\hline $\begin{array}{l}\text { Dissertação de } \\
\text { Mestrado }\end{array}$ & $\begin{array}{l}\text { O lugar da experiência } \\
\text { nos currículos de } \\
\text { história (1975-1998). }\end{array}$ & GUIMARÃES & $\begin{array}{lr}\text { Faculdade } & \text { de } \\
\text { Educação } & \text { da } \\
\text { Universidade } & \text { de } \\
\text { São Paulo - FEUSP }\end{array}$ & 2007 \\
\hline $\begin{array}{l}\text { Dissertação de } \\
\text { Mestrado }\end{array}$ & $\begin{array}{l}\text { O currículo e o Ensino } \\
\text { de História nos anos } \\
\text { finais do } \quad \text { ensino } \\
\text { fundamental. }\end{array}$ & MARIA & $\begin{array}{ll}\text { Faculdade } & \text { de } \\
\text { Educação } & \text { da } \\
\text { Universidade } & \\
\text { Federal do } & \text { Rio } \\
\text { Grande do Sul } & \end{array}$ & 2013 \\
\hline $\begin{array}{ll}\text { Tese } & \text { de } \\
\text { Doutorado } & \end{array}$ & $\begin{array}{l}\text { Currículo e Ensino de } \\
\text { História em uma escola } \\
\text { da rede municipal de } \\
\text { São Paulo: entre } \\
\text { prescrições e práticas. }\end{array}$ & $\begin{array}{l}\text { CARVALHO } \\
\text { FILHO }\end{array}$ & $\begin{array}{lr}\text { Faculdade } & \text { de } \\
\text { Educação } & \text { da } \\
\text { Universidade } & \text { de } \\
\text { São Paulo - FEUSP }\end{array}$ & 2015 \\
\hline
\end{tabular}

As produções acadêmicas selecionadas compõem um inventário das reformas curriculares do Ensino de História, produzidas no período de redemocratização, que contempla quatro estados - São Paulo, Rio de Janeiro, Rio Grande do Sul e Rio Grande do Norte -, em abordagens curriculares municipais, estaduais e federais, e fornece um parâmetro para a discussão em torno do conhecimento histórico selecionado para o currículo em momento anterior à Base.

Ao tratar do conhecimento histórico curricular, os autores apontam mudanças atribuídas aos novos objetivos do Ensino de História, associados às correntes historiográficas, à ampliação da noção de evidência histórica e às relações com os conceitos fundantes da disciplina. As permanências são elencadas em relação às propostas curriculares da década de 1970, com destaque para organização do conteúdo de ensino em "eras" históricas, períodos linear e cronológico. A análise desse material foi desenvolvida no item 2.1 desta tese, que versa sobre a seleção do conhecimento histórico curricular no período anterior à BNCC. 
Em relação ao segundo objetivo - identificar as disputas em torno do componente curricular de História durante o processo de elaboração da BNCC - o reconhecimento das fontes e a coleta de informações iniciaram-se pela identificação dos sujeitos que participaram do processo de elaboração do documento.

Para entender o caminho desenvolvido na pesquisa, faz-se necessário, primeiramente, compreender o processo em desenvolvimento no contexto histórico de elaboração da BNCC, que se inicia no ano de 2014, marco estabelecido pela publicação da Portaria do Conselho Nacional de Educação CNE/CP n. 11/2014, que elege uma Comissão Bicameral para

acompanhar e contribuir com o Ministério da Educação na elaboração de documento acerca dos direitos e objetivos de aprendizagem e desenvolvimento, tendo em vista, principalmente, as Estratégias 2.1 e 2.2 da Meta 2 e as Estratégias 3.2 e 3.3 da Meta 3, previstas no Plano Nacional de Educação aprovado pela Lei $N^{\circ} 13.005$, de 25 de junho de 2014 (BRASIL, 2014b).

As Metas 2 e 3 do Plano Nacional de Educação (PNE) (2014-2024) propõem a criação de uma base nacional curricular para o Ensino Fundamental e Médio, com o intuito de definir e implementar direitos e objetivos de aprendizagem e desenvolvimento para a formação básica comum dos alunos da educação básica (BRASIL, 2014a).

Sobre isso, vale destacar que a busca pela construção de um currículo comum não é recente na legislação educacional brasileira. Encontra-se, por exemplo, documentada na Lei n. 5.629/71, que fixa Diretrizes e Bases para o ensino de $1^{\circ}$ e $2^{\circ}$ graus e dá outras providências, com a criação do núcleo comum obrigatório em âmbito nacional.

Essa busca por definições curriculares comuns foi reforçada a partir das políticas educacionais desenvolvidas após a Constituição de 1988. Segundo Cury (2002), as mudanças educacionais brasileiras, no período posterior à Carta Magna, são caracterizadas pela noção de "educação básica" que, pela primeira vez, reúne os três segmentos, a Educação Infantil, o Ensino Fundamental e o Ensino Médio, definindo o acesso a eles como dever do Estado. Assim, tornou-se "um conceito mais do que inovador para um país que, por séculos, negou de modo elitista e seletivo, a seus cidadãos o direito ao conhecimento pela ação sistemática da organização escolar" (CURY, 2002, p. 170).

Essa ideia ganha força a partir da década de 1990, com a ampliação progressiva do acesso de todos à educação e a busca pela garantia de uma formação comum. A criação de uma base nacional comum e a fixação de conteúdos mínimos para o Ensino Fundamental é assegurada pela Constituição Brasileira de 1988, no Art. 210. Em seguida, a LDB nº 9.394, de 
12/12/1996, no Art. 26, determina que os currículos de ensino devem ter uma base nacional comum.

Ao longo do tempo decorrido para a elaboração da LDB nº 9.394/96, o papel do CNE foi reforçado pela Lei $\mathrm{n}^{\circ}$ 9.131/95, que lhe atribuiu centralidade na deliberação sobre as diretrizes curriculares para todas as modalidades de ensino do país. Porém, o Ministério da Educação (MEC) se antecipou ao CNE e elaborou, de forma acelerada, os Parâmetros Nacionais Curriculares (PCNs). Para Cury (2002, p. 190), essa antecipação, no governo de Fernando Henrique Cardoso, explica-se pelas

muitas "transições" em processo, as ausências e vacâncias, a expectativa de uma nova lei de diretrizes e bases, a existência de dois projetos de diretrizes e bases, a vontade de implementar programas em início de governo [que] determinaram no MEC a superposição de papéis que eram dele e de outros tantos que apenas provisoriamente estavam nele. A resultante foi a elaboração dos PCNs como se fossem a tradução do Art. 210 da Constituição Federal.

Dessa forma, foram criados e coexistiram no país dois documentos de orientação curricular: os PCNs, elaborados pelo MEC e homologados pelo CNE no final da década de 1990, e as Diretrizes Curriculares Nacionais (DCN), produzidas pelo CNE. Ambos os documentos tinham como objetivo o estabelecimento de orientações curriculares, porém o caráter do primeiro seria não normativo. O segundo, obrigatório e de caráter mais amplo, estabeleceu que "a base nacional comum na Educação Básica se constitui de conhecimentos, saberes e valores produzidos culturalmente" e expressos nas políticas e programas educacionais (BRASIL, 2010).

Outra investida no sentido de definir uma base comum para os currículos é apresentada no ano de 2015, através da Portaria do MEC n 592 , que institui a Comissão de Especialistas para a elaboração de uma base nacional comum. A Comissão deveria ser composta por 116 membros, professores pesquisadores das universidades, professores da educação básica, especialistas vinculados às secretarias de educação e profissionais da área indicados pelos Conselho Nacional de Secretários de Educação (CONSED) e União Nacional dos Dirigentes Municipais de Educação (UNDIME) (BRASIL, 2015).

A breve menção às etapas da construção da BNCC não é suficiente para o entendimento do complexo processo de construção do documento, o que exige a contextualização do cenário político e econômico, principalmente após a sucessão presidencial, com a cassação do mandato da presidenta Dilma Rousseff, em maio de 2016. Nesse difícil caminho, pela primeira vez na história do CNE, contou-se com a exoneração dos 
conselheiros eleitos democraticamente, pelo Decreto de 10 de maio de 2016 ${ }^{7}$. Ainda, a exoneração da equipe responsável pela primeira versão da BNCC e a constante substituição dos conselheiros da Comissão Bicameral, não devem ser negligenciadas na linha do tempo da sua elaboração.

O Decreto de 27 de junho de 2016 nomeou os novos membros do CNE e, em seguida, foi aprovada a Portaria CNE/CP no 15/2016, que estabeleceu o novo objetivo para a Comissão Bicameral, que consistia no "acompanhamento dos debates sobre a BNCC e a emissão de parecer conclusivo acerca da proposta a ser recebida pelo CNE”.

Segundo o discurso do governo à época, divulgado no sítio eletrônico ${ }^{8}$, a elaboração da primeira versão desse documento mobilizou diversos profissionais da educação, entidades educacionais e representantes de toda a sociedade. Ressaltamos que, entre os últimos, constam agentes financeiros ligados ao capital privado.

Para o MEC, a realização de fóruns, consultas públicas, seminários e outras atividades garantiram democratização do processo de elaboração da $\mathrm{BNCC}$, que cumpriu o seguinte cronograma: a primeira versão, disponibilizada pela Comissão em setembro de 2015, tornou-se acessível para consulta pública e envio de comentários em sítio eletrônico até março de 2016; a segunda versão, disponibilizada em maio de 2016, foi levada ao debate nos seminários estaduais, entre os meses de junho e agosto de 2016; por fim, em abril de 2017, o MEC entrega a terceira versão para o CNE, que realizou cinco audiências públicas sobre o texto da BNCC, entre os meses de junho e setembro de 2017. É importante ressaltar que a terceira versão da Base foi encaminhada para aprovação sem as questões referentes ao Ensino Médio, sendo este segmento tratado à parte, tendo seu processo finalizado em 2018.

Após um curto espaço de tempo, no qual foram realizadas as audiências públicas, o documento seguiu para aprovação pelo Conselho Pleno do CNE, em outubro de 2017, e foi encaminhado para homologação pelo MEC em dezembro.

\footnotetext{
${ }^{7}$ Decreto sem número, publicado no DOU n ${ }^{\circ}$ 89, quarta-feira, 11 de maio de 2016, Seção 2, página 1.

${ }^{8}$ No site do MEC é possível obter informações sobre o processo de elaboração da Base Nacional Comum Curricular e ter acesso aos seguintes documentos: regimento para realização das audiências públicas, calendário das Audiências Públicas, contribuições, minuta de Parecer e Projeto de Resolução que trata da BNCC 7/12/2017, Anexo - Texto BNCC, Parecer CNE/CP n 15/2017, aprovado em 15 de dezembro de 2017 - Base Nacional Comum Curricular (BNCC), anexo - Texto BNCC - Versão aprovada em 15 de dezembro de 2017, gravação da Sessão do Conselho Pleno do dia 15 de dezembro de 2017 e Resolução CNE/CP n ${ }^{\circ}$, de 22 de dezembro de 2017 - Institui e orienta a implantação da Base Nacional Comum Curricular, a ser respeitada obrigatoriamente ao longo das etapas e respectivas modalidades no âmbito da Educação Básica. Disponível em: http://portal.mec.gov.br/conselho-nacional-de-educacao/base-nacional-comum-curricular-bncc. Acesso em: 09 de abril de 2018.
} 
Ao analisar o contexto histórico do processo de elaboração da BNCC, identificamos a intensa participação de agentes ligados às instituições governamentais e não governamentais. Para reunir os documentos produzidos nesse processo, a busca pela documentação levou aos acervos on-line, nos sítios das instituições pesquisadas.

Identificamos dois tipos de acervos documentais. O primeiro, produzido e com acesso disponibilizado pelos órgãos governamentais relacionados às políticas educacionais brasileiras: MEC e CNE. O segundo acervo da documentação pertence às associações científicas que se manifestaram sobre o processo de elaboração do documento. Deste, escolhemos a ANPEd e a ANPUH. Esclarecemos que a divisão em instituições governamentais e não governamentais teve como finalidade identificar o espaço de atuação das instituições e dos sujeitos envolvidos no processo de elaboração, discussão e legitimação da BNCC.

A primeira associação científica não governamental escolhida, a ANPEd, trata das questões da educação de forma geral e contribui para um melhor entendimento sobre as questões curriculares, daí a importância de focalizar o debate sobre o Ensino de História em seu âmbito. A segunda, a ANPUH, discute o processo de elaboração curricular do componente disciplinar de História. O posicionamento da ANPUH é considerado relevante, pois se trata da maior associação de profissionais de História no Brasil, com mais de seis mil filiados distribuídos nas seções estaduais em todo território brasileiro.

No caso do grupo de instituições governamentais, a documentação é disponibilizada no sítio eletrônico do $\mathrm{MEC}^{9}$. Nesse portal, localizamos dois caminhos para o acesso à documentação sobre a BNCC. O primeiro está no próprio sítio do MEC e consiste na versão final do documento. O segundo, consiste nos links que permitem acessar o sítio de órgãos vinculados ao MEC no processo em discussão, em especial um link para o sítio do CNE.

Também no sítio do MEC há acesso a outro sítio que reúne materiais sobre a $\mathrm{BNCC}^{10}$. Nele se disponibiliza o material de apoio elaborado pelo MEC, em parceria com o CONSED e a UNDIME, com objetivo de apoiar e orientar as secretarias de educação e escolas na realização do "Dia D para estudo e discussão da BNCC", realizado no dia 6 de março de 2018.

\footnotetext{
${ }^{9}$ Disponível em: http://portal.mec.gov.br. Acesso em: 20 de março de 2018.

${ }^{10}$ Disponível em: http://basenacionalcomum.mec.gov.br. Acesso em 20 de março de 2018.
} 
Na aba do CNE, disponível no sítio do MEC, o que chama atenção são dois links denominados "BNCC". O primeiro trata do processo de elaboração da BNCC, entre a segunda e a terceira versão. O segundo, destina-se à BNCC do Ensino Médio. A organização das informações sobre a BNCC em abas distintas, denuncia a forma pela qual as questões do Ensino Médio são tratadas independentemente do processo geral de concepção da BNCC, embora a LDB 9394/96 já estabeleça que o ensino básico reúne os três segmentos: Educação Infantil, Ensino Fundamental e Ensino Médio, como mencionado anteriormente. A pesquisa focaliza o conteúdo da primeira dessas abas, já que trata do processo final de elaboração da Base para o Ensino Fundamental, com destaque para os debates desenvolvidos nas audiências públicas, as contribuições enviadas ao CNE e o processo de homologação do documento.

O conjunto de fontes da pesquisa reúne, portanto:

1. Regimento das audiências públicas;

2. Calendário das Audiências Públicas;

3. Contribuições encaminhadas ao $\mathrm{CNE}^{11}$;

4. Minuta de Parecer e Projeto de Resolução que tratam da BNCC - 7/12/2017, Anexo - Texto BNCC;

5. Parecer CNE/CP n ${ }^{\circ}$ 15/2017, aprovado em 15 de dezembro de 2017 - Base Nacional Comum Curricular (BNCC), Anexo - Texto BNCC - versão aprovada em 15 de dezembro de 2017;

6. Gravação da Sessão do Conselho Pleno do dia 15 de dezembro de 2017 e Resolução CNE/CP n 2, de 22 de dezembro de 2017 - Institui e orienta a implantação da BNCC, a ser respeitada obrigatoriamente ao longo das etapas e respectivas modalidades no âmbito da Educação Básica.

Foram catalogados 235 documentos escritos, encaminhados ao CNE com contribuições à proposta de texto da BNCC. Na maioria são cartas, ofícios e e-mails que tratam de diversos temas relativos ao currículo. Na análise da documentação foram escolhidos nove documentos, selecionados por abordarem assuntos relacionados ao conhecimento histórico a ser ensinado nas escolas. Esses documentos foram produzidos por professores, historiadores, representantes de associações, entre outros, que além de apreciarem questões relacionadas ao componente curricular de História, também contribuíram para compreensão

\footnotetext{
11 Disponível em: http://portal.mec.gov.br/component/content/article?id=57031. Acesso em 20 de março de 2018.
} 
das características gerais do currículo proposto, pelas menções às competências, habilidades, educação integral e outros temas. Quadro 5 - Relação dos documentos encaminhados ao CNE que tratam do componente
curricular de História

\begin{tabular}{|c|c|c|}
\hline Documento encaminhado ao CNE & $\begin{array}{l}\text { Responsável } \\
\text { produção e envio }\end{array}$ & Ano \\
\hline $\begin{array}{l}\text { Ofício } 220 \text { - Rio de Janeiro, } 15 \text { de janeiro } \\
\text { de } 2016\end{array}$ & ANPEd & 2016 \\
\hline $\begin{array}{l}\text { Ofício } 211 \text { ANPEd } \mathrm{n}^{\circ} \text { 030/2017 Rio de } \\
\text { janeiro, } 11 \text { de setembro de } 2017\end{array}$ & ANPEd & 2017 \\
\hline $\begin{array}{l}059 \text { Ofício - Parecer da ANPUH-SC sobre } \\
\text { a terceira versão da Base Nacional Comum } \\
\text { Curricular de História. }\end{array}$ & ANPUH-SC & 2017 \\
\hline $\begin{array}{l}070 \text { Ofício - ANPUH-SP na Audiência } \\
\text { sobre a Base Nacional Comum Curricular. } \\
\text { Conselho Nacional de Educação - } \\
\text { Comissão da Base Nacional Comum } \\
\text { Curricular. Audiência pública - Região } \\
\text { Sudeste. }\end{array}$ & ANPUH-SP & 2017 \\
\hline $\begin{array}{l}049 \text { Ofício - Proposta por Ricardo Moreira. } \\
\text { Título: Moral e Cívica e OSPB na BNCC } \\
\text { para mudar e libertar o Brasil! Audiência } \\
\text { pública do MEC - Base Nacional Comum } \\
\text { Curricular. }\end{array}$ & Ricardo Moreira & 2017 \\
\hline $\begin{array}{l}129 \text { Ofício - Brasília, } 11 \text { de setembro de } \\
2017\end{array}$ & José Pacheco & 2017 \\
\hline $\begin{array}{l}069 \text { Ofício - Síntese das leituras } \\
\text { críticas/recomendações dos especialistas }\end{array}$ & $\begin{array}{l}\text { Movimento Todos Pela } \\
\text { Base }\end{array}$ & 2017 \\
\hline $\begin{array}{l}\text { 131 Ofício - O Desenvolvimento Integral } \\
\text { na Base Nacional Comum Curricular - } \\
\text { Recomendações para Subsidiar Parecer do } \\
\text { CNE - Conselho Nacional de Educação. } \\
\text { Movimento pela Base. Com contribuições } \\
\text { de: Centro de Referências em Educação } \\
\text { Integral Instituto Inspirare; Instituto Ayrton } \\
\text { Senna; CIEB - Centro de Inovação para a } \\
\text { Educação Brasileira; Sociedade Brasileira } \\
\text { de Computação - SBC em Setembro de } \\
2017 \text {. }\end{array}$ & $\begin{array}{l}\text { Movimento Todos Pela } \\
\text { Base }\end{array}$ & 2017 \\
\hline $\begin{array}{l}222 \text { Ofício Alessio Costa Lima -Limoeiro } \\
\text { do Norte-Ceará. Seminário Base Nacional } \\
\text { Comum Curricular em debate: desafios, } \\
\text { perspectivas e expectativas, realizado nos } \\
\text { dias } 20 \text { e } 21 \text { de janeiro de } 2016 \text {, em } \\
\text { Brasília/ DF. }\end{array}$ & UNDIME & 2017 \\
\hline
\end{tabular}


Os nove documentos relacionados no Quadro 5 apresentam análises da BNCC de forma geral e posicionam-se de maneira favorável ou contrária a ela. Dentre eles, os dois produzidos pela ANPUH/SC e SP são contrários ao documento aprovado e aprofundam as questões curriculares em torno do Ensino de História ${ }^{12}$. Sete deles, apesar de não tratarem exclusivamente do componente curricular de História, a ele fazem referência.

Durante as cinco audiências públicas realizadas pelo CNE, foram registradas 283 manifestações orais dos participantes. O material em formato de vídeo foi analisado e as falas selecionadas na perspectiva de identificar os posicionamentos referentes ao conhecimento histórico dito como relevante para compor o currículo escolar. Adicionalmente, foram contempladas as falas que tratam de questões curriculares de relevância para o entendimento da BNCC, uma vez que não podemos compreender um componente curricular isoladamente, sem considerar as necessárias articulações com as concepções de educação e currículo presentes no documento.

Quadro 6 - Relação das falas realizadas nas Audiências Públicas que contemplam o componente
curricular de História
\begin{tabular}{|l|l|}
\hline Audiências Públicas-CNE & $\begin{array}{l}\text { Falas direcionadas ao componente curricular de } \\
\text { História }\end{array}$ \\
\hline $1^{\mathrm{a}}$. Audiência Pública - Manaus & Fórum de Educação Escolar Indígena \\
\hline $2^{\mathrm{a}}$. Audiência Pública - Recife & ANPUH/PE \\
\hline $3^{\mathrm{a}}$. Audiência Pública- Florianópolis & ANPUH/SC \\
\hline $4^{\mathrm{a}}$. Audiência Pública - São Paulo & ANPUH/SP e Ação Educativa \\
\hline $5^{\mathrm{a}}$. Audiência Pública - Brasília & ANPUH BRASIL \\
\hline
\end{tabular}

No quadro acima, identificamos a participação da ANPUH em quatro das cinco audiências realizadas pelo CNE. Partimos para o segundo movimento de busca por fontes, realizado nos sítios eletrônicos das associações científicas, ANPUH e ANPEd.

Na busca no site da ANPUH Brasil foram localizados 50 resultados que tratam da BNCC. Dentre esses, constam, por exemplo:

1. Propostas de eventos para discussão do currículo;

2. Relatos da participação nas audiências públicas;

3. Posicionamento da Diretoria em relação à BNCC;

4. Posicionamento da ANPUH no CNE;

5. Notas sobre as versões da BNCC.

\footnotetext{
${ }^{12}$ Ambos os documentos estão disponíveis nos Anexos.
} 
A documentação coletada data do período que vai de dezembro de 2015 a maio de 2018, contemplando o recorte da pesquisa. Após a coleta das fontes nos sítios do MEC, CNE e ANPUH, realizamos o cruzamento das fontes referentes à participação da ANPUH no processo de elaboração e discussão da Base, apresentadas no quadro abaixo:

Quadro 7 - Relação das falas realizadas nas audiências públicas pela ANPUH e localização da documentação

\begin{tabular}{|l|l|l|}
\hline $\begin{array}{l}\text { Audiências Públicas- } \\
\text { CNE }\end{array}$ & $\begin{array}{l}\text { Falas direcionadas ao componente } \\
\text { curricular de História }\end{array}$ & $\begin{array}{l}\text { Documento e acervo } \\
\text { disponível }\end{array}$ \\
\hline $\begin{array}{l}2^{\mathrm{a}} \text {. Audiência Pública }- \\
\text { Recife }\end{array}$ & $\begin{array}{l}\text { ANPUH/PE (duas falas - manhã e } \\
\text { tarde) }\end{array}$ & Vídeo/CNE \\
\hline $\begin{array}{l}3^{\mathrm{a}} \text {. Audiência Pública- } \\
\text { Florianópolis }\end{array}$ & $\begin{array}{l}\text { ANPUH/SC - Professor do Ensino } \\
\text { Fundamental e Médio do Colégio de } \\
\text { Aplicação da UFSC }\end{array}$ & $\begin{array}{l}\text { Vídeo / CNE } \\
\text { Documento escrito / CNE } \\
\text { Documento escrito/ ANPUH }\end{array}$ \\
\hline $\begin{array}{l}3^{\mathrm{a}} \text {. Audiência Pública- } \\
\text { Florianópolis }\end{array}$ & ANPUH/SC & $\begin{array}{l}\text { Vídeo/CNE } \\
\text { Documento escrito/ ANPUH. }\end{array}$ \\
\hline $\begin{array}{l}4^{\mathrm{a}} \text {. Audiência Pública - } \\
\text { São Paulo }\end{array}$ & ANPUH/SP & $\begin{array}{l}\text { Vídeo/CNE } \\
\text { Documento escrito / CNE } \\
\text { Documento escrito/ ANPUH }\end{array}$ \\
\hline $\begin{array}{l}5^{\mathrm{a}} \text {. Audiência Pública - } \\
\text { Brasília }\end{array}$ & ANPUH BRASIL & $\begin{array}{l}\text { Vídeo/CNE } \\
\text { Documento escrito/ ANPUH. }\end{array}$ \\
\hline
\end{tabular}

O quadro acima mostra a importância do cruzamento da documentação produzida e disponibilizada em diferentes acervos, com finalidade de identificar o maior número de fontes sobre o processo de participação da ANPUH no processo de discussão da Base.

Percebemos que as participações das regionais da ANPUH nas audiências públicas foram registradas e disponibilizadas de formas diferentes pelas entidades. Das cinco audiências realizadas pelo CNE, como já dito, a ANPUH participou de quatro, e todas foram registradas e disponibilizadas em vídeo pelo CNE. Porém, apenas duas falas - uma em São Paulo e outra em Florianópolis - foram encaminhadas ao CNE como contribuição em formato de texto e disponibilizadas nos sítios das duas instituições.

Ressaltamos que, na audiência de Florianópolis, ocorreram duas manifestações da ANPUH e apenas uma foi localizada em formato de ofício no sítio do CNE; a outra, só foi possível encontrar no sítio da $\mathrm{ANPUH}^{13}$, tal qual a carta lida na audiência pública de

13 Audiência da BNCC em Florianópolis. Fala da professora Nucia Oliveira pela Seção Santa Catarina da Associação Nacional de História. Disponível em: https://anpuh.org.br/index.php/2015-01-20-00-0155/noticias2/noticias-destaque/item/4690-audiencia-da-bncc-em-florianopolis. Acesso em: 23 de junho de 2017. 
Brasília $^{14}$. Já o posicionamento da ANPUH na audiência de Pernambuco foi encontrado apenas em formato de vídeo, como mostra o quadro anterior.

Compreendemos que a discussão curricular sobre o conhecimento histórico a ser ensinado nas escolas deve estar atrelado às noções de escola, educação e currículo. Dessa forma, a consideração dos posicionamentos dos profissionais do campo da Educação é necessária. A ANPEd mostrou-se atuante no processo de discussão crítica da BNCC. Na busca realizada no sítio da entidade foram localizados 74 resultados em torno da temática. $\mathrm{Na}$ sequência, cruzaremos as informações levantadas nessa documentação com as disponibilizadas pelo CNE.

A produção de outras instituições não governamentais também é objeto de análise, principalmente após o mapeamento das vozes nas audiências e nos encaminhamentos ao CNE. Dentre algumas, destacamos a Associação Brasileira de Currículo (ABdC), não possuidora de sítio eletrônico que disponibilize e sistematize a documentação produzida pela associação, mas que encaminhou seu posicionamento ao CNE no contexto das Audiências Públicas. Nessas ocasiões, a $\mathrm{ABdC}$ foi representada por sua presidenta, Professora Inês Barbosa de Oliveira (UERJ/UNESA), sua secretária-geral, Rita de Cássia Frangella (UERJ) e pela associada Elizabeth Macedo (UERJ), presidente da International Association for Advancement of Curriculum Studies (IAACS).

Numa análise preliminar desse documento, identificamos que a $\mathrm{ABdC}$ se posiciona a favor da flexibilização do currículo, mostrando-se fortemente contrária ao movimento de unificação curricular. Além disso, a associação afirma discordar "da construção de um documento pautado em objetivos de aprendizagem, sob qualquer formato".

Percebe-se que as três instituições citadas acima - ANPUH, ANPEd e ABdC -, têm em comum um forte posicionamento contrário ao processo de elaboração e aprovação da BNCC. A análise documental aprofundará essa questão, já que compreendemos que o processo de coleta dos dados nos fornece indícios de disputas e posicionamentos que não devem ser negligenciados.

No processo de coleta e organização dos dados, confirmamos que o currículo se constrói num campo de disputas, como já sinalizado com base no referencial teórico apresentado. No interior dessas disputas, localizamos a quarta instituição não governamental

\footnotetext{
${ }^{14}$ Audiência Pública e a 3a. versão da BNCC. GT de Ensino de História e Educação pela Associação Nacional de História/ANPUH. Disponível em: https://anpuh.org.br/index.php/2015-01-20-00-01-55/noticias2/noticiasdestaque/item/4343-audiencia-publica-e-a-3-versao-da-bncc-o-lugar-da-anpuh-no-debate.
} 
que participa do processo de elaboração da BNCC, com um posicionamento divergente das demais apresentadas. Referimo-nos ao Movimento Todos Pela Base Nacional Comum ${ }^{15}$.

Esse grupo apresenta-se como "um grupo não governamental de profissionais da educação que, desde 2013, atua para facilitar a construção de uma Base de qualidade". O sítio focaliza o processo de construção e implementação da BNCC e propõe-se a oferecer esclarecimentos acerca de possíveis dúvidas sobre o documento, além de reunir informações e construir interpretações sobre ele. Também oferece um Guia para Implementação da Base, produzido pelo CONSED e UNDIME (material em pdf) ${ }^{16}$. Na aba "Guia de Professores" há um link para os sítios da revista Nova Escola, voltada aos professores ${ }^{17}$, da Fundação Leman $^{18}$, com um guia para os professores (material em pdf), e da instituição Benchmarks Internacional $^{19}$, com material destinado aos gestores.

O sítio eletrônico do Movimento Todos pela Base Nacional Comum reúne um conjunto importante de documentos que permitem identificar e situar os sujeitos envolvidos no processo de elaboração e implementação da BNCC, principalmente as empresas privadas do ramo educacional que atuam como parceiras do governo federal. A análise desses materiais foi articulada com a análise da documentação do MEC, do CNE e das demais instituições não governamentais anteriormente indicadas.

Por fim, o último objetivo consiste na identificação do conhecimento considerado relevante para o Ensino de História, expresso na versão final da BNCC. Tem como documentos principais o Parecer CNE/CP n ${ }^{\circ}$ 15/2017 e a versão final da BNCC, no trecho que se refere ao Ensino Fundamental - anos finais (BRASIL, 2017a). O documento encontrase disponível no sítio eletrônico do MEC.

A terceira e última versão da BNCC para o Ensino Fundamental foi homologada em dezembro de 2017 e é composta pelos seguintes elementos: Introdução; A Estrutura da Base; A Etapa da Educação Infantil; e A Etapa do Ensino Fundamental. Ressaltamos que o elemento A Etapa do Ensino Médio foi incorporado ao documento no ano seguinte.

A introdução do documento apresenta a Base Nacional Comum Curricular e as dez competências gerais a serem desenvolvidas na educação básica. Em seguida, trata dos

\footnotetext{
${ }^{15}$ Disponível em: http://movimentopelabase.org.br. Acesso em 20 de março de 2018.

${ }^{16}$ Disponível em: https://implementacaobncc.com.br/wpcontent/uploads/2018/06/guia_de implementacao_da_bncc_2018.pdf. Acesso em 16 de junho de 2018.

${ }^{17}$ Disponível em: https://novaescola.org.br/base. Acesso em 04 de março de 2018.

${ }^{18}$ Disponível em: https://novaescola.org.br/base. Acesso em 04 de abril de 2018.

${ }^{19}$ Disponível em: http://movimentopelabase.org.br/benchmarks-internacionais. Acesso em 16 de junho de 2018.
} 
marcos legais que embasam o documento, dos fundamentos pedagógicos, delineia o pacto interfederativo e discute a implementação da BNCC. A análise dos elementos da introdução é necessária para a compreensão do componente curricular de História, no contexto pedagógico proposto. Dessa forma, o elemento descrito acima é analisado e articulado às preocupações com os aspectos do conhecimento histórico curricular. A etapa do Ensino Fundamental é apresentada em cinco páginas e igualmente faz-se necessária sua análise para a compreensão da disciplina de História no currículo.

O Ensino Fundamental é composto por cinco áreas de conhecimento: Linguagens, Matemática, Ciências da Natureza, Ciências Humanas e Ensino Religioso. O objeto da pesquisa elege o componente curricular de História para o Ensino Fundamental - anos finais, do $6^{\circ}$ ao $9^{\circ}$ ano, destinado aos alunos de onze a quatorze anos de idade. $\mathrm{O}$ componente curricular compõe, juntamente com a disciplina de Geografia, a área de Ciências Humanas, compartilhando sete competências específicas das Ciências Humanas para o Ensino Fundamental - anos finais.

Após a apresentação da Área das Ciências Humanas, inicia-se o componente de História, com a apresentação das setes competências de História para o Ensino Fundamental (BRASIL, 2017a, p. 400). No componente curricular de História no Ensino Fundamental anos finais, localizamos os itens: Unidades Temáticas; Objetos de Conhecimentos; e Habilidades. Esses são organizados em quadros definidos para cada ano de ensino.

Para todos os anos são quatro unidades temáticas. Nos $6^{\circ}$ e $7^{\circ}$ anos são, em média, dois a três objetos de conhecimento para cada unidade temática, dos quais derivam, respectivamente, 19 e 17 habilidades. Nos $8^{\circ}$ e $9^{\circ}$ anos percebemos um número maior de objetos de conhecimento para cada unidade temática, em média quatro, e um significativo aumento no número de habilidades, respectivamente 27 e 36.

Até aqui, coube apenas uma apresentação descritiva do documento, analisado adiante com base nas informações levantadas por meio do instrumento de pesquisa e confrontadas com as falas expressas no processo de elaboração da BNCC.

\subsubsection{Procedimentos e instrumentos}

Na busca por cumprir com todos os objetivos propostos na pesquisa, adotamos procedimentos metodológicos qualitativos aplicados às fontes anteriormente apresentadas. A 
fim de dar clareza sobre o caminho metodológico, partimos da pergunta de pesquisa ${ }^{20}$ e definimos as questões investigativas indicadas a seguir.

Para o primeiro objetivo - analisar o debate sobre o conhecimento histórico presente nos currículos escolares anteriores à $\mathrm{BNCC}-$, utilizamos, em pesquisa bibliográfica, a produção acadêmica sobre currículo e Ensino de História, produzida no período de 2000 a 2017, tendo como questão de investigação: quais as posições ressaltadas na produção acadêmica sobre os conhecimentos históricos assumidos como relevantes nos currículos de História, nos PCNs e em documentos nele embasados?

Para o segundo objetivo - identificar as disputas em torno do conhecimento para o Ensino de História, durante o processo de elaboração da BNCC - desenvolveu-se a análise documental voltada aos textos encaminhados e/ou produzidos pelo MEC, CNE, ANPUH e ANPEd. Neste caso, a questão de investigação que guiou o trabalho foi: quais as perspectivas dos profissionais da Educação e dos historiadores em relação aos conhecimentos históricos que deveriam ser abordados na escola no processo de produção da BNCC?

Por fim, para o terceiro objetivo - identificar o conhecimento considerado relevante para o Ensino de História na versão final da BNCC - também optou-se pela análise documental, que recaiu sobre as fontes do Parecer CNE/CP no 15/2017 e a versão final da BNCC, no trecho que se refere ao Ensino Fundamental - anos finais. A partir da seguinte questão de investigação, foi possível a orientação da leitura, e a identificação e discussão das permanências e mudanças nas escolhas curriculares operadas no período em análise: quais conhecimentos históricos foram definidos como essenciais no documento e quais vozes foram ouvidas e silenciadas na sua produção?

Para a organização da documentação coletada, seguimos a afirmação de Bardin (2016, p. 125), ao indicar que ela cumpre três etapas: "a escolha dos documentos a serem submetidos à análise, à formulação das hipóteses e dos objetivos e à elaboração de indicadores que fundamentem a interpretação final". Dessa forma, evidenciamos o que se objetiva na leitura de cada uma dessas fontes, estabelecendo a relação entre a documentação selecionada e os objetivos assumidos para a análise.

$\mathrm{Na}$ produção acadêmica sobre currículo e Ensino de História, produzida no período de 2000 a 2017, buscamos identificar rupturas e continuidades no processo de seleção do conhecimento histórico para compor o currículo escolar. Nos documentos encaminhados

20 A pergunta da pesquisa pretende compreender qual o conhecimento selecionado como relevante nos documentos curriculares da disciplina de História, bem como as justificativas para essas escolhas e as posições divergentes. 
e/ou produzidos pelo MEC, CNE, ANPUH, ANPEd esperamos identificar as propostas para o Ensino de História e comparar com o que se propunha antes da BNCC, promovendo, assim, a triangulação com o resultado obtido no objetivo anterior e com os dados resultantes da leitura do Parecer CNE/CP no 15/2017 e da versão final da BNCC, no trecho que se refere ao Ensino Fundamental - anos finais. Almejamos relacionar as posições defendidas nesses textos com os posicionamentos manifestados nas audiências e nos documentos encaminhados ao CNE, buscando compreender as disputas em torno do campo curricular de História, de modo a identificar as vozes silenciadas e as expressas na BNCC.

Uma vez selecionados os documentos, seguiu-se para a produção de roteiros de análise documental. Constatando que o conhecimento histórico curricular é o cerne de todos os objetivos e que explica a composição do acervo documental, o intuito foi identificar o conhecimento histórico escolar do Ensino Fundamental - anos finais, definido como legítimo no contexto anterior à Base, no processo de elaboração da BNCC e na versão final do documento, bem como as diferentes posições sobre essas seleções curriculares. Para isso, foi preciso criar um roteiro capaz de permitir o reconhecimento desse conhecimento histórico escolar em todos os documentos, bem como das diferentes apreciações sobre ele.

O roteiro é dividido em duas partes. A primeira, identifica e analisa a tipologia da fonte, objetivando compreender o documento para além da lógica discursiva. A segunda, aborda aspectos do conhecimento escolar da disciplina de História. Diante desse contexto, inquirimos os seguintes pontos: a justificativa para a permanência da disciplina de História no currículo escolar; a identificação da fundamentação teórica, no campo das correntes historiográficas; a identificação dos conceitos estruturantes da disciplina de História (Evidência, Mudança, Narrativa); a organização do conhecimento em relação às noções de tempo/espaço; a escolha dos temas e conteúdos historiográficos; a utilização dos processos metodológicos da investigação histórica; e, a depender, aspectos curriculares nos campos avaliativos e das aprendizagens. É importante destacar que os itens elencados são articulados entre si, porém não necessariamente contemplados em todos os documentos analisados.

Para além da identificação do conhecimento da disciplina de História manifesto nos documentos curriculares, fez-se necessário criar um segundo roteiro para análise dos documentos encaminhados e/ou produzidos pelo MEC, CNE, ANPUH e ANPEd, a fim de levantar informações sobre os seguintes aspectos: a) os sujeitos produtores dos documentos; b) o lugar social ocupado por eles; c) a proposta e/ou crítica curricular em relação ao componente de História. A ideia foi complementar o primeiro roteiro, potencializando a 
discussão sobre permanências ou rupturas em relação ao conhecimento curricular definido no contexto anterior à elaboração da BNCC. 


\section{APRESENTAÇÃO E DISCUSSÃO DOS DADOS}

Neste capítulo apresentamos os achados da pesquisa no que se refere ao conhecimento histórico curricular presente nos documentos anteriores à $\mathrm{BNCC}$, no processo de elaboração do componente de História da Base e na versão final do documento, homologado em 2017.

No tópico 2.1 apresentamos as produções acadêmicas sobre Currículo e Ensino de História. Em seguida, realizamos a análise bibliográfica da produção acadêmica e, para isto, utilizamos o roteiro de análise com objetivo de identificar as críticas aos aspectos do conhecimento histórico, expressos nos documentos curriculares anteriores à BNCC. Buscamos, com isso, responder quais os conhecimentos assumidos como relevantes e quais diferentes posições sobre essa escolha estavam em cena.

No tópico 2.2 realizamos a análise documental dos ofícios encaminhados ao CNE, por ocasião da discussão das versões da BNCC. Inicialmente, identificamos as instituições e entidades que se manifestaram em relação ao componente curricular de História. Em seguida, por meio da análise dos documentos, identificamos as críticas e proposições destinadas ao documento curricular da disciplina em questão. Por fím, comparamos os resultados com o que se propunha nos documentos curriculares anteriores à BNCC - segundo os debates reconhecidos na produção acadêmica. Neste tópico inquirimos sobre quais as perspectivas dos profissionais da Educação e dos historiadores em relação aos conhecimentos históricos que deverão ser abordados na escola. O roteiro de análise objetivou identificar os aspectos do conhecimento histórico e promover a triangulação dos dados apresentados no tópico anterior.

No tópico 2.3 realizamos a análise documental do Parecer CNE/CP n 15/2017 e a versão final da BNCC, no trecho que se refere ao Ensino Fundamental - anos finais. Inquirimos sobre quais os conhecimentos históricos que foram definidos como essenciais nos documentos e, também, quais vozes foram ouvidas e silenciadas no documento prescrito. Inicialmente, analisamos as escolhas curriculares realizadas pelo CNE que justificaram a aprovação do documento final. Em seguida, identificamos as concepções de currículo, conhecimento e competências manifestadas no documento curricular. Avançamos com a análise dos aspectos do conhecimento histórico escolar referente ao componente de História na BNCC. Finalmente, no item 2.4, realizamos a triangulação dos dados, a partir da comparação entre as análises de experiências curriculares anteriores à Base, os posicionamentos manifestados nas audiências e nos documentos encaminhados ao CNE e as posições apresentadas no texto da Base. 


\subsection{A DEFINIÇÃO DO CONHECIMENTO HISTÓRICO NOS CURRÍCULOS ANTERIORES À BNCC}

A BNCC de História (2017a) compõe a reforma curricular mais recente e encontra-se em processo de implementação nas ações de formação docente, na elaboração dos currículos locais e na produção do material didático. Para compreendê-la, enquanto processo socialmente construído, fez-se necessário reconhecer as discussões sobre os aspectos do conhecimento histórico curricular, expressos em documentos curriculares anteriores à BNCC de História.

O intuito foi reconhecer os conhecimentos históricos assumidos como relevantes nos currículos da disciplina de História anteriores à BNCC, em especial nos PCNs, bem como as diferentes posições sobre essas escolhas que estavam em cena. Ao considerar que os PCNs são tomados como documentos curriculares relevantes na maioria das produções analisadas, tornou-se imprescindível uma breve apresentação do contexto de construção deste referido documento.

Os PCNs foram produzidos a partir da reflexão sobre os currículos elaborados nas décadas de 80 e 90, logo após o período de redemocratização do país. As reformas curriculares, municipais e estaduais, produzidas na década de 80, surgem no contexto de ruptura "marcada pelo discurso que dava ênfase à necessidade de recuperar a relevância social dos conteúdos escolares veiculados na escola, contrapondo-se às orientações tecnicistas que prevaleceram na década anterior" (BARRETTO, 1998, p. 08).

Nesse contexto, das propostas curriculares produzidas em diferentes estados e municípios, a Constituição Brasileira de 1988, no Art. 210, declara a necessidade de fixar “conteúdos mínimos para o Ensino Fundamental, de maneira a assegurar formação básica comum e respeito aos valores culturais e artísticos, nacionais e regionais" (BRASIL, 1988).

Concernia ao Governo Federal elaborar um documento para servir de parâmetro para realização das novas propostas curriculares. Em 1995, o Ministério da Educação e do Desporto solicita à Fundação Carlos Chagas uma análise dos currículos existentes, para subsidiar a elaboração dos PCNs para o Ensino Fundamental. A equipe analisou as propostas curriculares de 21 estados da federação, do Distrito Federal e dos municípios do Rio de Janeiro, Belo Horizonte e São Paulo, elaboradas entre os anos de 1985 e 1995. O trabalho deu origem ao documento denominado "As Propostas Curriculares Oficiais" (BARRETTO, 1998, p. 02).

A equipe de História, coordenada pela professora Circe Bittencourt, da Universidade de São Paulo, analisou 23 propostas curriculares de História, inquirindo-as com 
as seguintes questões: "Por que ensinar História?" e "O que e como ensinar?" Segundo a autora, a justificativa para o Ensino de História era associada à necessidade da formação para a cidadania em contexto da redemocratização. Os conteúdos históricos são definidos, em sua predominância, pelo tempo linear cronológico e a alternância entre os acontecimentos históricos europeus e de ordem da História local; por fim, identificava-se a metodologia como parte da prescrição curricular, associando-a ao método investigativo da História (BITTENCOURT, 2018, p. 158-160).

O instrumento elaborado nesta pesquisa, para analisar a produção acadêmica sobre as reformas curriculares anteriores à BNCC, contempla as questões inquiridas por Bittencourt (1998) - "Por que ensinar História?" e "O que e como ensinar?" - Porém, percebemos a necessidade de aprofundar aspectos do conhecimento histórico escolar para compreender as escolhas realizadas. Dessa forma, interessa, além de compreender a justificativa, entender o conteúdo e o método do Ensino de História apresentados nas propostas curriculares, associando tais questões à fundamentação teórica do campo historiográfico, à utilização dos conceitos estruturantes e à organização do conteúdo em relação às noções de tempo e espaço.

Partir desse cenário anterior à BNCC teve a intenção de contribuir para a identificação de rupturas e continuidades no processo de seleção do conhecimento histórico, que compõe os documentos que orientam o currículo escolar. Para tal fim, inventariamos a produção acadêmica sobre Currículo e Ensino de História, produzida no período de 2000 a 2017, atentos para as percepções das diferentes posições, defesas de temáticas e críticas das abordagens curriculares do Ensino de História.

O subitem está dividido em duas partes. Na primeira, apresentamos as produções acadêmicas, conjuntamente aos documentos curriculares tratados por elas. E na segunda parte, analisamos os aspectos do conhecimento histórico escolar anterior à BNCC, por meio do roteiro de análise.

\subsubsection{Apresentação das produções acadêmicas e dos documentos curriculares analisados}

Selecionamos para análise cinco pesquisas, três teses e duas dissertações ${ }^{21}$, escolhidas devido à profundidade da discussão em relação ao conhecimento histórico curricular e, adicionalmente, pela amplitude das fontes analisadas pelos pesquisadores.

\footnotetext{
${ }^{21}$ As produções acadêmicas selecionadas sobre Currículo e Ensino de História, foram produzidas no período de 2017 a 2020 e apresentadas no item Metodologia, Quadro 04.
} 
As pesquisas selecionadas analisaram os currículos prescritos e os currículos em ação, com objetivo de perceber o alcance dos primeiros na prática docente em sala de aula. Destacou-se, nesses textos, aspectos que remetem ao estudo dos documentos curriculares prescritos para a disciplina de História nas séries finais do Ensino Fundamental, produzidos durante o período pós-regime militar. Os dez documentos curriculares, analisados pelas cinco pesquisas, foram produzidos nas esferas municipais, estaduais e federal, nas décadas de 80 e 90, nos estados do Rio de Janeiro, São Paulo, Rio Grande do Norte e Rio Grande do Sul, conforme o quadro abaixo:

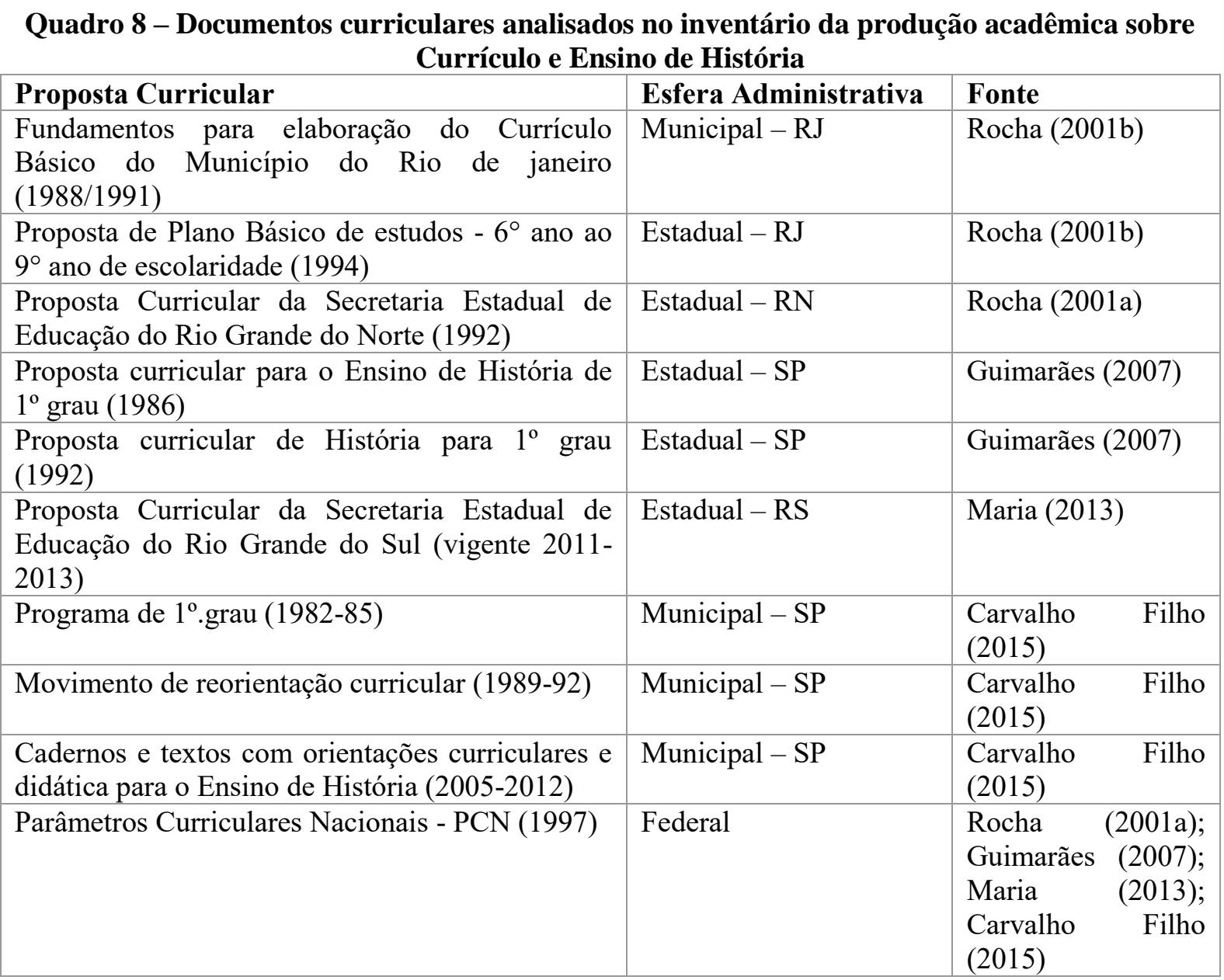

A primeira pesquisa analisada ${ }^{22}$, produzida por Rocha (2001b), discute as reformas curriculares ocorridas no Rio de Janeiro, na esfera municipal, durante as décadas 80 e 90 e as reformas curriculares estaduais, do segundo ciclo do Fundamental, em 1994. Na esfera municipal, o pesquisador analisou o processo de reformulação curricular, iniciado em

22 As pesquisas foram analisadas por ordem cronológica de produção: Rocha (2001b); Rocha (2001a); Guimarães (2007); Maria (2013) e Carvalho Filho (2015). 
1983 e finalizado em 1991, identificou permanências e mudanças nas propostas curriculares e denominou o conjunto das propostas como "Fundamentos para elaboração do Currículo Básico do Município do Rio de Janeiro (1988/1991)". Na esfera estadual, o autor identificou a influência das reformas curriculares municipais no documento estadual "Proposta de Plano Básico de estudos - $6^{\circ}$ ano ao $9^{\circ}$ ano de escolaridade (1994)" e sinalizou as divergências políticas entre as esferas municipais e estaduais do governo, que influenciaram no contexto de elaboração e implementação dos currículos escolares. O estudo contextualiza a produção dos documentos curriculares atrelados às políticas de governo e adota a tríade concepções de currículo, historiografia e teoria da aprendizagem para analisar os documentos curriculares do componente de História, a partir das seguintes questões: organização temática, concepções de História, construção de conceitos e influência da psicologia genética.

A segunda pesquisa, produzida por Rocha (2001a), analisa as clivagens entre o que é proposto no currículo formal, elaborado pelo estado, e o que é executado no currículo real, desenvolvido nas escolas do Rio Grande do Norte. No campo do currículo prescrito, o autor discute as principais características das propostas oficiais para o Ensino de História na proposta da Secretaria Estadual de Educação do Rio Grande do Norte, de 1992, e nos PCNs (BRASIL, 1997).

O Currículo Estadual do Rio Grande do Norte foi produzido pela professora Jecí Bulhões. O documento foi influenciado pela proposta curricular do estado de São Paulo, de 1986, e a versão preliminar, de $1992^{23}$, sinalizava, em certa medida, a circularidade de ideias, já que a autora teve acesso ao documento paulista, o qual inspirou a adoção da organização curricular por Eixos Temáticos (ROCHA, 2001a, p. 153).

O PCN de História também incorporou ideias de outras propostas curriculares já existentes, por exemplo, as do estado de São Paulo, adotando "o trabalho por Eixo Temático e a crítica à linearidade, progresso e evolução" (ROCHA, 2001a, p. 183). Apresentou, também, inovações: a concepção de identidade, enriquecida pelo estudo da diversidade; a articulação do conhecimento histórico aos estudos educacionais, ao orientar a aprendizagem por meio de atitude e comportamento; a promoção da autonomia docente na seleção dos conteúdos; o detalhamento do processo avaliativo; e, por fim, os encaminhamentos metodológicos a partir da ampliação do conceito de documento histórico.

\footnotetext{
23 Os dois documentos referenciados, Proposta Curricular para o Ensino de História de $1^{\text {o }}$ grau, de 1986, e da Proposta Curricular de História para o $1^{\circ}$ grau, de 1992, são analisados na pesquisa de Guimarães (2007).
} 
A terceira pesquisa, produzida por Guimarães (2007), analisa os três últimos currículos paulistas de História, produzidos em períodos anteriores aos PCNs. Em acordo com o recorte temporal estabelecido nesta pesquisa, deu-se atenção à análise desenvolvida pelo autor da "Proposta Curricular para o Ensino de História de $1^{\circ}$ grau", de 1986, e da "Proposta Curricular de História" para o $1^{\text {o }}$ grau, de 1992, além do PCN de História, de 1997. O autor identifica as tensões envolvidas na definição do lugar da escola, do conteúdo histórico e da experiência discente, e afirma que as reformas curriculares estavam diretamente relacionadas ao acesso à escola por novos alunos, principalmente oriundos das camadas populares (GUIMARÃES, 2007, p. 116).

A quarta pesquisa selecionada, produzida por Maria (2013), analisa o currículo e o Ensino de História na realidade educacional brasileira, tomando como objeto de estudo as turmas de sétima e oitava séries do Ensino Fundamental de uma escola pública pertencente à rede estadual de ensino do Rio Grande do Sul, na periferia da cidade de São Leopoldo. O objeto da pesquisa é o currículo em ação, mas a autora apresenta aspectos dos PCNs e características do currículo prescrito do estado, vigente nos anos de 2011 a 2013.

A pesquisadora apresenta a estrutura do PCN História e, em seguida, analisa o documento a partir de três aspectos: o primeiro diz respeito à separação das disciplinas História e Geografia nos anos iniciais do Ensino Fundamental; o segundo, ao caráter formativo da História na "constituição da identidade, da cidadania e do (re)conhecimento do outro, do respeito à pluralidade cultural e ao fortalecimento da democracia" (2013, p. 49); o último aspecto refere-se à organização dos conteúdos por Eixos Temáticos, considerada pela autora como expressão de uma "ruptura com a tradicional estrutura curricular organizada cronologicamente através dos grandes fatos" (MARIA, 2013, p. 49).

A autora identifica até que ponto os aspectos citados acima são percebidos no Currículo Estadual de São Leopoldo. Por exemplo, ao analisar o planejamento realizado pela unidade escolar, a autora destaca que o terceiro aspecto descrito acima, que trata da organização do conteúdo por Eixos Temáticos, não é adotado no currículo da unidade escolar, que segue na manutenção da lista de conteúdos no modelo quadripartite, já que: "O currículo de História para o E.F. está dividido em quatro grandes períodos Históricos: no $6^{\circ}$ ano os estudantes aprendem a Pré-História e a História Antiga; na $6^{\mathrm{a}}$ série, História Medieval e Moderna; na $7^{\mathrm{a}}$ e $8^{\mathrm{a}}$ séries, a História Contemporânea"(p. 68).

Por fim, a quinta produção, de Carvalho Filho (2015), analisa os trabalhos acadêmicos e as propostas curriculares elaboradas pela rede municipal de ensino de São Paulo, no período 1982-2012. São três os documentos focalizados: "Programa de $1^{\circ} \mathrm{Grau}$ 
(1982-85)", o "Movimento de Reorientação Curricular (1989-92)" e os cadernos e textos com orientações curriculares e didáticas para o Ensino de História elaborados pela gestão Pinotti/Schneider (2005-2012).

Carvalho Filho (2015, p. 76), em consonância com Rocha (2001a), destaca a influência dos PCNs nos documentos curriculares municipais, ao afirmar que: "alguns pressupostos teórico-metodológicos do documento nacional, particularmente no que se refere à História escolar foram incorporados à proposta curricular da rede municipal, as 'Orientações Curriculares"'. Segundo o autor, os currículos da década de 90 têm a preocupação com: "competências e habilidades na resolução de problemas, que guardam resquícios de concepções emprestadas das teorias de administração empresarial" (CARVALHO FILHO, 2015, p. 92).

Ressaltamos que as reformas curriculares realizadas na década de 80 e 90 surgem no contexto de conflito político entre as esferas governamentais: federal, estadual e municipal, como também entre as transições governamentais do mesmo nível. Nesse sentido, Guimarães (2007, p. 70) identifica o descompasso entre as esferas federal e estadual, e também nas sucessões internas (estaduais), ao afirmar que:

a explicação das mudanças curriculares pelas alterações de projeto político também é buscada, não só na década de 1970 do Regime Militar, mas também na passagem dos anos 1980 aos anos 1990. Todavia, sob um outro nível: estadual.

O movimento crescente de elaboração de propostas curriculares, produzidas nas esferas estaduais e municipais, é atribuído ao contexto de redemocratização política do país, ocorrida na década de 80, o qual resultou em eleições democráticas para os governos dos estados, gerando, assim, autonomia e oposição em relação ao governo Federal, de caráter militar. Nesse sentido, encaminhou-se um movimento de descentralização das políticas educacionais e de elaboração dos documentos curriculares municipais e estaduais, conforme expresso no quadro 08 .

As descontinuidades nas políticas de elaboração e implementação dos documentos curriculares também é percebida por Rocha (2001b, p. 70). No município do Rio de Janeiro, entre os anos de 1988 a 1991, o documento curricular produzido em uma gestão municipal era retomado e reformulado na gestão seguinte, e uma vez finalizado e publicado, não avançava para a implementação, pois a gestão findava e, assim, começava um novo ciclo. Rocha (2001b, p. 70) identifica, na sequência dos documentos produzidos e em diferentes gestões 
municipais $^{24}$, ideias que permaneceram entre as gestões, como também alterações significativas, principalmente em relação ao componente de História, analisadas no próximo item.

As cinco pesquisas apresentadas compõem um inventário das reformas curriculares produzidas no início do período democrático e podemos concluir, dessa primeira análise, que os estudos curriculares utilizados nesta pesquisa têm preocupação central em compreender a articulação entre os currículos prescritos e os currículos em ação, embasados pelas concepções curriculares de Ivor Goodson (1997) e Sacristán (2000), que reafirmam a importância e especificidade de cada dimensão do currículo e a necessidade de estudá-lo na sua perspectiva de processo; identificam conflitos no processo de elaboração do documento curricular nas esferas governamentais em seus três níveis - municipal, estadual e federal; associam as transições governamentais como elementos motivadores das reformas curriculares, não apenas na mudança do regime militar para o regime democrático, mas também durante o processo de redemocratização - nas políticas de governo que orientam as reformas educacionais, em caminhos de permanências e rupturas de acordo com os interesses políticos do governo vigente; e, por fim, identificamos a presença acentuada de referências aos PCNs nas pesquisas analisadas, seja como fruto de análises curriculares produzidas nas décadas de 80 e 90, ou como documento de referência para a produção de novas propostas curriculares em estados e municípios.

Cumprida a apresentação das produções acadêmicas sobre Currículo e Ensino de História, assim como os documentos curriculares tratados por estas, seguimos com a análise das produções, no que versa sobre conhecimento histórico escolar apresentado nos dez documentos curriculares antecedentes à BNCC.

\subsubsection{Aspectos do conhecimento histórico escolar expressos em documentos anteriores à BNCC}

A produção acadêmica, referente aos estudos do Currículo do Ensino de História para os anos finais do Ensino Fundamental produzidos entre os anos de 2000 a 2017,

\footnotetext{
24 O pesquisador analisa o processo de reformulação curricular do município do Rio de Janeiro entre os anos de 1988 a 1991. O texto Fundamentos para Elaboração do Currículo Básico do Município do Rio de Janeiro é composto pela compilação dos documentos a seguir: Grupo tarefa de Estudos Sociais - por uma nova História... propostas de Mudança (SME/RJ, s.d); História - 5 . a $8^{\mathrm{a}}$. séries. Livro azul (SME/RJ, 1988); Conhecer História fazendo História (D.O.M/ RJ, 15 jun.1988); Fundamentos para elaboração do currículo básico das escolas públicas do Munícipio (SME/RJ, 1991); Sugestões Metodológicas: $2^{\circ}$ segmento do $1^{\circ}$ grau - História (SME/RJ, 1992) e Componente de História da Multieducação (SME/RJ, s.d).
} 
possibilitou analisar o conhecimento histórico escolar selecionado nos documentos curriculares anteriores à BNCC.

As produções acadêmicas abordam o currículo de História em perspectivas diferentes, porém todas promovem, em certa medida, reflexões sobre o conhecimento histórico escolar. Nesse quadro multiperspectivado, orientamos a investigação sobre o conhecimento histórico curricular anterior à $\mathrm{BNCC}$, a partir dos seguintes aspectos: a justificativa para o retorno e permanência da disciplina de História no currículo escolar ${ }^{25}$; a identificação da fundamentação teórica, no campo das correntes historiográficas; a identificação dos conceitos estruturantes da disciplina de História (Evidência, Mudança, Narrativa); a escolha dos temas e conteúdos historiográficos; a organização do conhecimento em relação às noções de tempo/espaço; a utilização dos processos metodológicos da investigação histórica e, a depender, aspectos curriculares nos campos avaliativos e das aprendizagens.

A compreensão do conhecimento histórico curricular permite identificar o sentido atribuído à disciplina de História. Por isso, nesta pesquisa buscamos identificar a justificativa para o retorno e permanência da disciplina no currículo escolar, em documentos produzidos em período anterior ao da vigência da BNCC.

Nos documentos curriculares do Rio de Janeiro, analisados por Rocha (2001b), o retorno e a permanência da disciplina de História no currículo escolar são justificados por um viés pragmático, uma vez que o conhecimento histórico do passado, associado à realidade do aluno, tornaria possível compreender a realidade e transformá-la. Segundo o autor, a legitimação do Ensino de História pelo atributo da transformação da realidade era

presente, com maior ou menor insistência nos currículos propostos e, como justificativa para a sua serventia, embutida em tradicionais definições de História, dependendo da metodologia utilizada na configuração dos 'elos associativos', produzia, certamente, características singulares ao currículo realmente trabalhado (ROCHA, 2001b, p. 16).

\footnotetext{
25 Ao escolher analisar a justificativa para o retorno e permanência da disciplina de História no currículo escolar, consideramos o contexto apontado por Silva e Fonseca (2010), ao afirmarem que "Os Parâmetros Curriculares Nacionais (PCNs) [...]. Em primeiro lugar, [...] oficializaram, em âmbito nacional, a separação das disciplinas 'História e Geografia' nos anos iniciais do, após anos de lutas e críticas à sua fusão, predominante nos currículos escolares durante e após o governo da Ditadura Civil-Militar (é importante ressaltar que a fusão é anterior a 1964). Essa mudança curricular já havia sido realizada em alguns estados da Federação, como Minas Gerais e São Paulo, no movimento de reforma curricular da década de 1980. A estrutura do Ensino Fundamental, definida pelos PCNs, em 1997, pôs fim aos Estudos Sociais como componente curricular, fosse como área ou como disciplina" (SILVA e FONSECA, 2010, p. 17-18).
} 
O caráter singular evidenciado pelo autor indica a dificuldade em entender que tipo de transformação da realidade o conteúdo de História poderia proporcionar, ao ser associada ao cotidiano dos alunos por via das metodologias do ensino desta disciplina. $\mathrm{O}$ autor chama atenção para as diferentes abordagens do perfil do aluno nos currículos estaduais e municipais, ainda que ambas as esferas apresentassem ideias de transformação social pela Educação, embora atendessem finalidades políticas antagônicas. Os currículos estaduais foram elaborados a partir das políticas de cunho neoliberal e priorizavam a formação do indivíduo para o mercado de trabalho e, sob perspectiva diferente, os currículos municipais promoviam a formação do aluno para uma cidadania crítica. Esse campo de convergências e divergências, sobre a função da escola e o caráter amplo e impreciso da ideia da Educação para a transformação da realidade, conduziam os currículos escolares do Rio de Janeiro (ROCHA, 2001b, p. 70).

Para Rocha (2001a, p. 155), no período da ditadura militar, o Ensino de História perdeu a função de reflexão/crítica. Recuperada e desenvolvida com o processo de redemocratização da política brasileira e presente nas propostas curriculares do Rio Grande do Norte (1992) e nos PCNs (1997), buscou promover uma nova função para a disciplina de História "na medida em que ambas as propostas curriculares estão preocupadas em trabalhar com conteúdos que estimulem o aluno a perceber as diversidades - e não as homogeneidades - que constituem a História” (ROCHA, 2001a, p. 150).

Sob o novo prisma das questões identitárias, rompe-se com as justificativas produzidas nos documentos curriculares anteriores, as quais remetiam às origens do Ensino de História ao estudo do passado para constituição de uma identidade nacional única e homogênea. Nesse novo contexto, "a preocupação não é mais a de criar uma identidade nacional homogênea, mas detectar as diversidades conflitantes que caracterizam a nossa formação" (ROCHA, 2001a, p. 156). A questão das identidades sociais não só legitima a permanência da disciplina no currículo, como orienta as escolhas curriculares.

Para Rocha (2001a, p. 164), o documento "Currículo Estadual do Rio Grande do Norte" não trata especificamente das questões de identidades, mas os conteúdos e métodos sugeridos estimulam o aluno a estabelecer relações de identidade. Por exemplo, quando propõe a articulação entre a história nacional e a história universal, na perspectiva das diferenças culturais, e em diálogo com o cotidiano do aluno para a formação das identidades múltiplas.

$\mathrm{O}$ autor destaca que o documento do PCN de História reconhece que "o sentido das identidades no Ensino de História está relacionado ao respeito às pluralidades culturais, 
étnicas, políticas, sociais e outras" (ROCHA, 2001a, p. 175). Sob o mesmo ponto de vista, Maria (2013) também ressalta as questões de identidades como lugar de atuação do Ensino de História no PCN, quando afirma que este documento curricular pontua "o caráter formativo da História na constituição da identidade, da cidadania e do (re)conhecimento do outro, do respeito à pluralidade cultural e ao fortalecimento da democracia" (MARIA, 2013, p. 49). Pontua, ainda, que a presença da disciplina de História no documento curricular do PCN está fundamentada na contribuição do estudo da História para a formação dos estudantes (MARIA, 2013, p. 53).

No PCN de História, os objetivos do ensino orientam a função do conteúdo historiográfico, que deverá:

contribuir para a formação intelectual e cultural dos estudantes; favorecer o conhecimento de diversas sociedades historicamente constituídas por meio de estudos que considerem múltiplas temporalidades e proporcionar a compreensão de que histórias individuais e coletivas se integram e fazem parte da História (ROCHA, 2001a, p.179).

Percebemos que os objetivos assumidos para o Ensino de História, de favorecer a formação dos estudantes amparando-se nas questões identitárias em contexto de diversidade e pluralidade, não só legitimam a permanência do componente de História no currículo, bem como orientam a organização e escolha do conteúdo histórico, ao propor o diálogo entre a História do Brasil e as dos demais povos e culturas do mundo, ao estabelecer a relação das experiências individuais e coletivas na construção do processo histórico e, por fim, ao considerar a complexidade das temporalidades históricas.

Em continuidade com o movimento de retorno e permanência da disciplina de História no currículo escolar, ocorrida na década de 80, Guimarães (2007, p. 68) sinaliza para uma crise de legitimidade do Ensino de História:

Não é apenas uma forma de saber histórico escolar que é questionada: essa visão é pensada apenas posteriormente. É a própria disciplina, o próprio currículo: numa palavra, a própria existência do Ensino de História na escola é colocada em suspenso e problematizada.

Para o autor, o que está em jogo não se restringe às mudanças em relação ao conhecimento da disciplina de História, já sinalizadas nos documentos curriculares do Rio de Janeiro, Rio Grande do Norte e nos PCNs. A crise de legitimidade apontada por Guimarães 
(2007, p. 68) é ancorada em duas preocupações: a primeira refere-se à nova função do ensino - contextualizada pelo quadro de transformações ocorridas no cenário político e social da redemocratização, que amplia o acesso do público ao sistema escolar, conjuntamente transformam os objetivos do ensino e consequentemente o currículo. E a segunda, ao papel do conhecimento no currículo, representada pela disputa entre a socialização do conhecimento acadêmico e a produção de um conhecimento escolar.

A estratégia para legitimar a permanência da disciplina de História no currículo estadual paulista, nos anos de 1986 e 1992, segundo Guimarães (2007, p. 68), foi “a associação do discurso curricular ao discurso produzido pela academia". A proposta Curricular de 1986 anunciava a nova função da escola e consequentemente do Ensino de História, "a função socializadora da escola é substituída por uma tarefa de produção de conhecimento pelos próprios alunos" (GUIMARÃES, 2007, p. 76). Essa posição foi revertida na proposta curricular de 1992, ao retornar a perspectiva socializadora da escola e ao se atribuir um papel importante aos debates e tendências historiográficas para dar sentido à experiência docente (p. 105). Para o autor, o impasse referente à função da escola em relação ao conhecimento no currículo - socializadora ou produtora do conhecimento - ganha amplitude na proposta dos PCNs ao reconhecer que o saber acadêmico está presente e imbricado no currículo escolar (GUIMARÃES, 2007, p. 107), e que a escola possui um papel socializante do conhecimento acadêmico, mas não se restringe a esse fim, já que reconhece que os saberes produzidos nas escolas são complexos e diversos, pois partem das realidades específicas.

Os documentos curriculares municipais paulistas, das gestões de Guiomar Namo de Mello (1982-85) e Paulo Freire/Mario Sergio Cortella (1989-92), também relacionam o retorno e a permanência da disciplina de História ao contexto de transformação social da época e às transformações no público escolar. Ambos os documentos assumem um "discurso comum do compromisso de garantir ao maior número de crianças e jovens dos setores majoritários da sociedade, a melhor escolarização possível" (CARVALHO FILHO, 2015, p. 53). Amparado nesta assertiva, o Ensino de História é justificado no currículo por conta do compromisso com a formação político-social do aluno. A primeira gestão legitima a disciplina de História no currículo pela função social da escola na "ampliação do conceito cidadania da esfera política formal para outros domínios da vida social" (p. 53). Para a segunda gestão, a "História tem papel central para que o aluno se reconhecesse como construtor da História e como cidadão pleno" (CARVALHO FILHO, 2015, p. 64). 
Por outro lado, os cadernos e textos com orientações curriculares e didáticas para o Ensino de História, elaborados pela gestão Pinotti/Schneider (2005-2012), frente à Secretaria Municipal de Educação de São Paulo, expressam a compreensão de que há um “discurso com ênfase em uma suposta perda da qualidade da educação pública, e consequente perda de competitividade do capital humano, frente às exigências do mercado globalizado" (CARVALHO FILHO, 2015, p. 66). Nesta abordagem, o Ensino de História deixa de ter a centralidade para a formação do indivíduo cidadão em contexto local, deslocando-se a importância a ele atribuída para a esfera da formação do indivíduo em contexto global, alinhando-se às exigências do capital econômico.

O deslocamento de foco da formação da cidadania no âmbito local para o global é percebido por Barretto (1998, p. 12) ao afirmar que a função da escola, assumida nas décadas de 80 e 90, era formar para a cidadania. Mas, em contextos diferentes, a pauta da formação para cidadania ganha contornos específicos. Na década de 80 , a relação entre escola e cidadania se estabelece pelo direito da população à educação, fator que proporcionaria a igualdade entre os cidadãos. Assim, as noções de cidadania e democracia são associadas aos objetivos da educação escolar, no recorte do processo de redemocratização da política brasileira. Na década de 90, a pauta da educação passa a contemplar os interesses: econômicos, estimulados pela competitividade externa; políticos, com objetivo de preservar o sistema democrático; e, por fim, sociais. Quanto a esses, Barretto (1998) afirma que "o discurso de igualdade é substituído pelo discurso da diferença. Se antes o democrático era buscar a igualdade, agora o democrático é respeitar as diferenças" (p. 18).

$\mathrm{Na}$ análise das justificativas para o retorno e permanência da disciplina de História nos currículos escolares percebemos: primeiro, a permanência da preocupação em formar o aluno para a cidadania; segundo, a ampliação do conceito de cidadania para além das preocupações políticas; e, por fim, um deslocamento da formação da cidadania do espaço local para o global. A formação da identidade dos estudantes é o cerne da disciplina de História, seja na perspectiva do cidadão pertencente a um Estado - nas propostas da década de 1980 e parte da década de 1990 - ou na formação de identidades múltiplas em contexto global - expressa nos documentos produzidos no final da década de 1990.

Seguindo a análise da produção acadêmica, identificamos, nas propostas curriculares de História, a fundamentação teórica no campo das correntes historiográficas. E, em que medida, essas definições se alinham com as justificativas da permanência da disciplina no currículo escolar? 
Rocha (2001b) afirma que as primeiras reformas curriculares, iniciadas nas décadas de 80 e 90, tinham como objetivo o restabelecimento no currículo do Ensino de História e Geografia, ocupado pela disciplina de Estudos Sociais, mas que não se tratava apenas do retorno da disciplina de História. Questões mais complexas estavam em jogo, e uma delas era a mudança da corrente historiográfica dita Tradicional, de base positivista, para diferentes tendências teóricas historiográficas. A corrente historiográfica do Materialismo Histórico, de orientação marxista, era a mais perceptível na documentação curricular produzida no Rio de Janeiro, nas décadas de 80 e 90. Para o autor, a escolha por esta corrente permitiu continuar os estudos dos conteúdos historiográficos em recortes macro e micro espaciais, evitando uma possível fragmentação do conteúdo histórico, já que

o recurso ao marxismo deveu-se, ao que parece, dentre outros motivos, à necessidade de se produzir uma comunicação, ao mesmo tempo, ampla e abreviada, com as listagens e quadros temáticos, que parecem nos diferentes textos curriculares. O marxismo é, ainda, o único instrumento disponível para se produzir uma visão sintética do processo histórico (ROCHA, 2001b, p.57). ${ }^{26}$

Apesar da predominância nos documentos curriculares alicerçar-se no Materialismo Histórico, o autor aponta que outras correntes historiográficas, tal como a Nova História, aparecem timidamente nas propostas metodológicas do currículo direcionadas aos docentes (ROCHA, 2001b, p. 49). Ele sinaliza, ainda, a circularidade das questões historiográficas para além do documento curricular ao afirmar que "os currículos escritos e da sala da aula refletem, de algum modo, os 'progressos', provenientes de diferentes tendências teóricas, alcançadas pela produção historiográfica, nas últimas décadas” (ROCHA, 2001b, p. 07).

O currículo do Rio Grande do Norte (1992), de acordo com Rocha (2001a), reúne diferentes visões da História atribuídas às diferentes correntes historiográficas. Ao contrário das escolhas dos documentos reformulados do Rio de Janeiro, não há predominância de uma determinada linha teórica. Rocha (2001a) atribui à corrente historiográfica da Nova História a ampliação do conceito de documento histórico nas propostas curriculares potiguares, em oposição ao paradigma da História Positivista dita tradicional.

No campo da Nova História, Rocha (2001a) destaca a influência da tríade: novos problemas, objetos e abordagens, que se baseia na perspectiva do historiador Peter Burke

\footnotetext{
${ }^{26}$ A citação é a fala do pesquisador que além de analisar a documentação, também participou da elaboração de dois dos seis documentos curriculares em questão.
} 
(1992, p. 10). Este autor define a Nova História pela negação ao paradigma historiográfico dito tradicional e propõe "definir a nova história em termos do que ela não é, daquilo a que se opõem seus estudiosos”. Na lógica da oposição, podemos associar que as reformas curriculares baseadas no campo historiográfico da Nova História se opõem ao Ensino de História dito tradicional, ancorado em bases positivistas.

Porém, Rocha (2001a) alerta que a amplitude dos temas, sujeitos e abordagens da Nova História possibilita uma constante fragmentação do conhecimento historiográfico e, consequentemente, isto se expressa no ensino da disciplina. Essa é uma preocupação também evidenciada no processo de elaboração dos documentos curriculares do Rio de Janeiro, que legitimam a escolha teórica pelo Materialismo Histórico.

Apesar das diferentes escolhas teóricas, Rocha (2001a e b) reconhece que as mudanças curriculares ocorridas respectivamente no Rio de Janeiro e no Rio Grande do Norte, nas décadas de 80 e 90, foram inovadoras no campo teórico e metodológico do Ensino de História. Atribui, ainda, as mudanças curriculares às questões da produção historiográfica. No caso do primeiro, às questões marxistas, já no segundo, ao campo do Neomarxismo e da Nova História.

Guimarães (2007, p. 65) destaca a retomada da História como disciplina no currículo paulista de 1986, amparada na renovação do Ensino de História pelo estabelecimento de um novo diálogo com o conhecimento historiográfico. Afirma que: "um dos recursos utilizados pela Proposta de 1986, por exemplo, para legitimar o saber histórico escolar, e que não deixou de ser adotado desde então, foi a associação do discurso curricular ao discurso produzido pela academia" (GUIMARÃES, 2007, p. 68).

O documento curricular de 1986 contém anexos com proposta de debate historiográfico: "questões referentes ao ofício do historiador e à historiografia tem destaque no documento para o Ensino de História" (GUIMARÃES, 2007, p. 80). O autor sinaliza, ainda, a "possibilidade do debate de concepções historiográficas diversas" (p. 81), a resultar em "uma outra perspectiva de ensino, de pesquisa e de produção de conhecimento" (GUIMARÃES, 2007, p. 85). Em suas palavras:

A Proposta de 86, por exemplo, teria sofrido influência das discussões e dos debates que a História Social inglesa estava realizando nos últimos anos. Fundamentando-se principalmente no historiador E. P. Thompson, o documento curricular teria incorporado a cara noção de experiência e o tema do trabalho numa perspectiva pedagógica. Naquele momento, o historiador inglês estava já divulgando seus trabalhos que, ao mesmo tempo em que faziam a crítica do entendimento estruturalista althusseriano do marxismo, também mostravam a necessidade de compreender a relação da formação de 
uma classe social com suas experiências sociais (GUIMARÃES, 2007, p. 97).

$\mathrm{O}$ autor também percebe as vozes dos dois campos historiográficos no PCN História: "além de incorporar as discussões travadas pela Historiografia Social inglesa, também teria sofrido influência da Nova História francesa" (GUIMARÃES, 2007, p. 97).

Carvalho Filho (2015), em consonância com as afirmações de Rocha (2001a e b), destaca que os documentos curriculares municipais, em especial o documento paulista Movimento de Reorientação Curricular (1989-92), insere aspectos dos campos historiográficos para romper com a dita História tradicional. Ele reconhece:

a incorporação de tendências historiográficas cujo ponto comum era estabelecer a ruptura com a denominada "História tradicional ou positivista", em que bastava ater-se à ordem cronológica - do passado longínquo para o passado recente - e à memorização da sucessão de civilizações e nomes de reis ou "figuras notáveis" para realizar a aprendizagem (CARVALHO FILHO, 2015, p. 62).

$\mathrm{O}$ autor ainda acrescenta que o movimento foi no sentido de

integrar as teorias psicogenéticas à historiografia, particularmente às relacionadas à Nova História Social ou à terceira geração dos "Annalles", de modo a fundamentar a inserção da História de vida do aluno e da História local no processo de construção da narrativa histórica (2015, p. 61).

Já os cadernos e textos com orientações curriculares e didáticas para o Ensino de História elaborados pela gestão Pinotti/Schneider (2005-2012), no município de São Paulo, apresentam as concepções de currículo e de História e orientam construtos sobre ensinoaprendizagem que buscam subsidiar a construção do currículo e a seleção dos conteúdos históricos. $\mathrm{O}$ autor identifica que as pessoas que elaboraram as propostas paulistas foram as mesmas que formularam o PCN e, desse modo, essa aproximação entre os documentos curriculares de História é justificada. A esse respeito, diz o autor:

desde o início do processo de discussão e elaboração das propostas formuladas pelos grupos de referência, os trabalhos foram coordenados pela historiadora Antonia Terra de Calazans Fernandes, da Universidade de São Paulo, que também assumiu a responsabilidade pela elaboração final do "Referencial". A mesma Antonia Terra, em parceria com a historiadora Circe Maria Fernandes Bittencourt, coordenaram a elaboração das "Orientações Curriculares - História (CARVALHO FILHO, 2015, p. 87). 
De certo, a influência das correntes historiográficas da História Social inglesa e da Escola dos "Annales" - representada pela terceira geração da Nova História - , promove a ruptura com alguns paradigmas da História dita positivista e põe em cena sujeitos históricos trabalhadores, mulheres, crianças, pobres - e suas experiências, que até então eram silenciadas pelo Ensino de História dito tradicional, possibilitando, assim, ampliar e aprofundar as discussões sobre as identidades individuais e coletivas para além da noção homogeneizadora de identidade nacional.

Ao analisar a fundamentação teórica dos documentos curriculares de História no período anterior à BNCC, percebemos consensos na "ênfase em algumas noções e conceitos vinculados à produção historiográfica mais recente" (CARVALHO FILHO, 2015, p. 92). A partir de indícios de uma certa hegemonia de determinadas concepções de História nos documentos curriculares, buscou-se identificar conceitos estruturantes da disciplina de História atrelados às noções de Evidência, Mudança e Narrativa, para, assim, estabelecer a relação direta entre a fundamentação teórica do campo historiográfico e seus conceitos estruturais.

Rocha (2001b, p. 49) identifica que as noções de tempo e mudança são as mais recorrentes nos documentos curriculares do Rio de Janeiro, produzidos nas décadas de 80 e 90. A noção de tempo, associada à articulação entre o passado e o presente, é justificada pela ideia de dar sentido ao Ensino de História, a partir de um exemplo "concreto" da realidade associado ao conhecimento histórico do passado. O diálogo entre o passado e o presente é realizado através da problematização dos conceitos associados às preocupações historiográficas marxistas, entre eles as questões referentes ao Trabalho, Cultura e Sociedade.

Dessa forma, os conceitos estruturantes da corrente historiográfica do Materialismo Histórico, predominantes nos documentos curriculares do Rio de Janeiro, assumem dupla função: promover o diálogo entre as temporalidades passado e presente e organizar os conteúdos históricos, de modo que, “ao final da $8^{\mathrm{a}}$. série, o aluno deveria, por exemplo, sobre a sua noção de cotidiano de trabalho, ter construído uma outra, mais sofisticada, fruto de uma reflexão sobre as formas de trabalho nos diferentes tempos e espaços" (ROCHA, 2001b, p. 52).

O autor chama atenção para o fato de que o documento Proposta de Plano Básico de estudos $6^{\circ}$ ano ao $9^{\circ}$ ano de escolaridade (1994), produzido pela esfera estadual e com forte influência dos documentos municipais, mantém a utilização dos conceitos "Trabalho, Sociedade e Cultura", mas com a finalidade de organizar cronologicamente e espacialmente os conteúdos (ROCHA, 2001b, p. 45). Segundo ele, inova ao problematizar a relação 
passado/presente para além da construção histórica dos conceitos historiográficos (Trabalho, Cultura e Sociedade), inserindo duas novas preocupações: a primeira, uma peculiar ênfase aos objetivos e, a segunda, a reflexão da noção de transformação histórica, sinalizando assim aproximações com outras correntes historiográficas (ROCHA, 2001b, p. 76).

Rocha (2001, p. 149) alerta que com o processo de democratização da sociedade brasileira, no final dos anos 1970 e na década de 1980, as ideias da História Social passaram a ser incorporadas definitivamente no Ensino de História, provocando grandes modificações nos currículos propostos para a disciplina. Mudanças foram verificadas pela abordagem dada aos conceitos atrelados aos modos de produção, discutidos pelo viés neomarxista. O autor identifica no documento curricular do Rio Grande do Norte os conceitos de Classe Social, Trabalho e Alienação, para além da perspectiva do Materialismo Histórico. Nesse sentido, Peter Burke (1992, p. 35) lembra que trabalhos como os de Edward Thompson, historiador da História Social inglesa

foram muito bem sucedidos ao revelar as inadequações das explicações materialistas e deterministas tradicionais do comportamento individual e coletivo de curto prazo, e na demonstração de que tanto na vida cotidiana, quanto nos momentos de crise, o que conta é a cultura.

Thompson (1998, p. 17) chama a atenção para o risco do uso do termo Cultura na perspectiva consensual ou na mera descrição de significados, atitudes e valores. Para o autor, o conceito de Cultura é complexo e não deve ser levado a distrações: “o próprio termo cultura, com sua invocação confortável de um consenso, pode distrair nossa atenção das contradições sociais e culturais, das fraturas e oposições existentes dentro do conjunto”. Dessa forma, na concepção thompsoniana, a noção de Trabalho ressalta o seu caráter de construção sociocultural, a partir das experiências dos sujeitos históricos "sob formas historicamente específicas das relações sociais" (THOMPSON, 1998, p. 22).

Com base na orientação da História Social inglesa, o documento curricular do Rio Grande do Norte elege nove conceitos essenciais para alcançar os objetivos do Ensino de História - História; Homem; Relações Sociais; Ação do homem; Ato histórico; Visão de totalidade; Cotidiano; Conhecimento e Elucidação da realidade (ROCHA, 2001a, p. 156). Em relação às escolhas conceituais do documento curricular e a respeito da finalidade de promover o diálogo das preocupações do cotidiano do aluno com o passado histórico, o documento promove e aprofunda as noções de tempo, diferença/semelhança, 
permanências/mudanças, relações sociais e grupos sociais, para que o aluno seja capaz de localizar-se nas diversas temporalidades (ROCHA, 2001a, p. 159).

Segundo Rocha (2001a, p. 175) as principais noções desenvolvidas no documento curricular do PCN de História são diferenças, semelhanças, transformações e permanências. Segundo o autor, tais noções são essenciais para compreender a diversidade, já que "a partir da compreensão desses conceitos o aluno poderá identificar e distinguir o 'eu' do 'nós' no tempo; práticas distintas e as relações sociais em um mesmo espaço ou em tempos diferentes" (p. 175). Dessa forma, percebemos a coerência no documento entre os objetivos do Ensino de História e os conceitos estruturantes da disciplina. Além de proporcionar inovações teóricasmetodológicas, já que os conceitos acima consideram a noção de tempo em diferentes níveis e ritmos de durações temporais (ROCHA, 2001a, p.178) e contrapõem-se a visão de evento histórico limitado às ações dos governantes, ditos heróis pela História Tradicional de viés positiva: "os PCN enfatizam as relações de complementaridade, continuidade, descontinuidade, circularidade, contradição e tensão com outros fatos de uma época e de outras épocas" (ROCHA, 2001a, p. 177).

Em relação à noção de experiência, Guimarães (2007) afirma que ela é inserida no documento de 86 , na perspectiva de contraponto ao documento de 75 , ao incluir a experiência popular dos alunos no contexto escolar. Indica ainda que a noção permanece nos documentos curriculares de 92 e 98, mas em abordagens diferentes. No documento de 92, tem como objetivo atribuir significado à realidade do aluno (p. 104). O autor critica a noção de experiência apresentada no documento curricular, ao afirmar que a experiência do aluno, anterior à escola, não é considerada (p. 104) e que o não uso dessas experiências anteriores compromete o entendimento dos mesmos a respeito das noções temporais de anterioridade, simultaneidade e posterioridade (GUIMARÃES, 2007, p. 105). Assim, o autor considera que, com essa escolha, o documento promove a ideia de que a escola constrói uma visão melhor da realidade do que o próprio aluno (p. 105), representando assim uma "colonização da experiência discente" (GUIMARÃES, 2007, p. 105).

No PCN de História, a noção de experiência rompe com a ideia do documento de 92 e retoma as preocupações da proposta de 86, ao atribuir ao Ensino de História o papel de transformar o indivíduo a partir do modo que ele compreende o mundo (GUIMARÃES, 2007, p. 113). Neste documento, a ação transformativa se dá em torno do conceito de cidadania, amparada na aproximação entre o discurso acadêmico e o discurso do currículo escolar, que possibilita "multiplicar os espaços de aquisição de informações por parte dos alunos para além do escolar" (p. 111). Para o autor, os PCNs rompem com o posicionamento do documento de 
96 em relação à experiência discente, pois promovem a "internalização de uma perspectiva que dê novos sentidos às suas próprias vivências e recolocam o aluno em novas medidas e noções temporais, espaciais e sociais" (GUIMARÃES, 2007, p. 113).

Carvalho Filho (2015), além de identificar os conceitos considerados relevantes nos documentos que analisa, chama atenção para o possível enfraquecimento conceitual mediante o processo de integração das disciplinas escolares. $O$ autor identifica $o$ aparecimento dos conceitos de identidade e cidadania como meios para a legitimação da disciplina no currículo, nas propostas de 1982-85. Mas alerta que os conceitos aparecem na:

Integração curricular entre Geografia e História por meio da adoção de um tema comum [que] trazia o risco de diluição dos conhecimentos disciplinares com a consequente perda de aprofundamento dos conceitos e métodos próprios de cada uma dessas disciplinas. Prevendo que essa situação pudesse ocorrer, o "Programa" propôs a adoção de "eixos de análise", baseados nos conceitos de "trabalho" e "cultura", que seriam uma espécie de roteiro prévio para o professor fazer a abordagem dos conteúdos específicos da disciplina junto aos seus alunos (CARVALHO FILHO, 2015, p. 55).

O autor continua o alerta para o processo de integração entre as disciplinas, que favorece o esvaziamento dos conceitos disciplinares e fundantes das ciências ensinadas. Aponta que o Movimento de Reorientação Curricular (1989-92) promove a integração das disciplinas e ressalta que a

flexibilidade proporcionada por esse arranjo, se por um lado facilita o intercâmbio interdisciplinar na configuração do ensino, por outro dificulta a demarcação do campo epistemológico de cada uma das disciplinas, bem como torna mais difícil identificar a especificidade dos conceitos e noções pertinentes a elas (CARVALHO FILHO, 2015, p. 62).

Ainda no campo dos conceitos fundantes, adentramos as noções de tempo e espaço, que são essenciais para a compreensão da própria concepção da disciplina de História, além de definir a organização do conhecimento no documento curricular e a escolha dos temas e conteúdos historiográficos.

Segundo Rocha (2001b) os documentos curriculares do Rio de Janeiro, produzidos nas décadas de 80 e 90, embasados pela perspectiva historiográfica do Materialismo Histórico, orientaram as decisões curriculares do componente de História, entre estas, a escolha e organização dos conteúdos históricos. Para Rocha (2001b, p. 37) "a relação entre seleção de conteúdo e o significado que eles possam ter para os alunos" foi a preocupação recorrente nos documentos curriculares do Rio de Janeiro, em especial no texto 
curricular produzido em $1991^{27}$. O que se pretendia era a busca por conteúdos considerados significativos, que dialogassem diretamente ou indiretamente com as questões problemas do tempo presente vivenciado pelos alunos e, assim, produzissem um entendimento do seu lugar social em relação à vida e à cultura.

$\mathrm{O}$ autor também identificou mudanças em relação à definição de conceitos, conteúdos e objetivos, porém todas amparadas nas orientações marxistas. Nos documentos produzidos na década de 80, o autor destaca a organização dos conteúdos por temas. Chama atenção para a $5^{\text {a }}$ série, na qual a "organização dos conteúdos é temática, mas assenta-se numa estrutura conceitual” (ROCHA, 2001b, p. 39). Dessa forma, os conceitos do Materialismo Histórico (Trabalho, Cultura e Sociedade) seriam pré-condição para o aluno prosseguir os estudos dos conteúdos temáticos da História, associados aos casos concretos oriundos do cotidiano (ROCHA, 2001b, p. 40).

Já nos documentos curriculares produzidos na década de 90, identificamos mudanças na organização do conteúdo em torno de Eixos Conceituais. Os conceitos-chave que eram discutidos apenas na $5^{\mathrm{a}}$ série, passam a ser discutidos em todas as séries e assumem a função de organizar cronologicamente e espacialmente os conteúdos. Os conceitos centrais são retomados em todas as séries, porém a $5^{\mathrm{a}}$ série ainda é considerada o ano introdutório para as questões conceituais de explicação historiográfica (ROCHA, 2001b, p. 44-45).

Ainda na década de 90, o conhecimento histórico curricular passa a ser organizado nas séries por Eixo Conceitual (ROCHA, 2001b, p. 48). Segundo o autor: “os conceitos de Trabalho, Sociedade, Cultura e a noção de tempo histórico passam, [...], a funcionar como eixos norteadores dos conteúdos selecionados para as diferentes épocas/espaços; no Brasil, na América e no mundo" (p. 52). O Eixo Conceitual de Trabalho (coletivo, escravo, servil e assalariado) passa a organizar o conteúdo em diferentes espaços e temporalidades (p. 57). Na trajetória das reformas curriculares, o campo conceitual aderiu a uma perspectiva interdisciplinar a partir de núcleos conceituais de Identidade, Tempo, Espaço e Transformação, mantendo conceitos de inspiração marxista, ao propor princípios educativos a partir das preocupações com: Meio Ambiente, Trabalho, Cultura e Linguagens.

Rocha (2001a, p. 153), ao analisar o currículo do Rio Grande do Norte, identifica que para o ensino do primeiro grau (atual Ensino Fundamental) há uma ruptura com a ideia de lista de conteúdos e que a organização passa a ser por Eixos Temáticos, tal como na proposta

\footnotetext{
27 Ubiratan Rocha (2001b, p. 37) enfatiza que a manutenção do trecho sobre o conteúdo histórico significativo para o aluno foi percebida em três documentos curriculares: SME/RJ s.d; SME/RJ, 1987; SME/RJ, 1991.
} 
elaborada pela Secretaria de Educação do Estado de São Paulo (1986), que serviu de referência para a autora do documento. A escolha metodológica para organizar o currículo em eixos temáticos ocorreu

como forma de trabalhar com diferentes visões dos vários grupos sociais, estabelecendo uma relação de ir-e-vir entre presente e passado; possibilitar que o aluno ultrapasse a dimensão meramente individual do cotidiano e avance numa perspectiva tanto coletiva, quanto individual; e, finalmente, possibilitar também a articulação entre a qualidade do ensino nas escolas públicas e a luta mais geral dos trabalhadores em educação por uma sociedade mais crítica (ROCHA, 2001a, p. 156).

A opção metodológica pela organização dos conteúdos em Eixos Temáticos é a expressão do duplo recurso de organizar o conteúdo histórico em evolução linear e cronológica do tempo e em quatro períodos - História Antiga, História Medieval, História Moderna e História Contemporânea -, tradicional temporalidade histórica quadripartite.

Para o autor, o PCN significou um processo inovador do Ensino de História ao organizar os conteúdos em torno de Eixos Temáticos. Isso exigiu um debate sobre as noções de tempo histórico, questionando as concepções de linearidade, progresso, decadência e evolução presentes nos currículos anteriores (ROCHA, 2001a, p. 173). O documento considera os conceitos e os conteúdos historiográficos importantes, mas chama atenção para a complexidade do conteúdo a ser ensinado, ao lembrar que "o conteúdo a ser ensinado deve contemplar procedimentos e atitudes a serem desenvolvidos pelos alunos, não se restringindo apenas ao estudo de conhecimentos e conceituações históricas” (ROCHA, 2001a, p. 179).

Além disso, o PCN ressalta a importância de compreender as noções de identidade e cidadania, construídas historicamente, através das temporalidades. Para isso, fazem-se necessárias escolhas pedagógicas que destaquem as noções de diferenças, semelhanças, transformações e permanências (ROCHA, 2001a, p. 175). Dessa forma, o PCN de História explora a noção de tempo histórico a partir de diferentes níveis e ritmos de duração, permeadas pelas percepções das mudanças e/ou permanências das experiências humanas (ROCHA, 2001a, p. 178).

Rocha (2001a, p. 28) aprofunda a discussão ao afirmar que duas redefinições para o Ensino de História afetaram as propostas curriculares. A primeira, o reconhecimento da especificidade do saber escolar, resultando na adoção de um método de ensino específico. A segunda, a impossibilidade do domínio de toda a História da humanidade, resultando na superação da uniformização dos conteúdos. Assim, para esse autor, citando o PCN, justifica- 
se a importância e necessidade da seleção dos conteúdos mediante a impossibilidade "de estudar a História de todos os tempos e sociedades". Para o autor,

longe das certezas, que fornecem o confronto, a história se constitui enquanto disciplina, a partir dos conflitos. São conflitos entre as correntes historiográficas; são conflitos entre as teorias curriculares; são conflitos gerados na implementação das políticas educacionais (ROCHA, 2001a, p. 28).

No documento curricular do Rio Grande do Norte, os temas são anuais para o segundo ciclo do Ensino Fundamental e enfatiza-se a História do Brasil e de outros países da América por meio da diversidade cultural dos povos latino-americanos (p. 160-161). O conteúdo histórico escolhido como relevante confere centralidade à História do Brasil, em diálogo com a História de outros povos. Segundo o autor, o documento inova ao romper com a ideia de identidade homogênea e propõe o estudo das relações entre identidades através do estudo das diferenças culturais a partir do local como referência e identificação das diferentes relações entre a História Nacional e a História Universal em espaços e tempos distintos (ROCHA, 2001a, p. 164). Ainda assim, o autor constrói a crítica ao documento, quando afirma que "mesmo tentando ultrapassar a prescrição de conteúdo, faz indicações muito precisas de temas" (ROCHA, 2001a, p. 160-161), embora reconheça que a opção por Eixos Temáticos é um avanço metodológico.

Já no PCN de História, Rocha (2001a) verifica um abandono do estudo de todo o conteúdo histórico acumulado pela humanidade, em nome dos estudos comparativos de tempos e espaços. O autor afirma que o documento tem como objetivo "buscar os seus elementos de identidades a partir da relação de diferença com outros sujeitos, outros espaços e outros tempos" (p. 167), segundo as "diferenças entre o seu local de vivência e outros espaços mais amplos" e buscando "diferenciar-se com outros tempos e espaços" (ROCHA, 2001a, p. 171).

De acordo com o autor, o PCN de História confere aos professores autonomia na escolha dos conteúdos historiográficos e os alerta em relação às seguintes questões: a impossibilidade de ensinar todo conhecimento histórico em todas as temporalidades; a possibilidade da integração entre a História do Brasil e a História Geral; a necessidade dos estudos históricos partirem do olhar dos povos da América; a importância da relação entre os conteúdos da História local e regional; e, por fim, a opção da organização do conteúdo por Eixos Temáticos (ROCHA, 2001a, p. 173). Para o autor, a opção por organizar o conteúdo em Eixos Temáticos está associada diretamente às funções assumidas para o conteúdo de 
História, que são: formar intelectual e culturalmente os estudantes; conhecer as diversas sociedades historicamente construídas (múltiplas temporalidades); e compreender as histórias individuais e coletivas que se integram e fazem parte da História.

Guimarães (2007) aborda a organização do conhecimento em relação às noções de tempo e espaço, mas não aprofunda suas reflexões. Se detém a discutir os temas e conteúdos historiográficos em termos da obrigatoriedade, ou não, de sua escolha pelos docentes.

Em relação à proposta curricular paulista de 1986, o autor destaca a ausência da lista de conteúdos, rompendo assim com a estrutura curricular anterior. O documento articula com cautela os termos, conteúdos e temas, ao propor o estudo de momentos históricos. Ademais, sugere a abordagem de "temas clássicos" da historiografia, tais como a Primeira Guerra Mundial, a Depressão de 1929 e o Surgimento dos blocos capitalistas e socialistas, entre outros. Para o autor, isso se faz na intenção de evitar um tom prescritivo dos conteúdos históricos, uma vez que "o sentido daquelas expressões indica muito mais delimitações temáticas de campos de trabalho, no interior dos quais os professores exerceriam sua tarefa com os alunos na disciplina de História” (GUIMARÃES, 2007, p. 82).

Já o documento de 1992, retoma a lista de conteúdos, abandonada no documento curricular anterior, porém são estabelecidos de forma flexível e sem o caráter prescritivo. Para o autor, o conteúdo histórico escolar expõe os laços estreitos entre a universidade e a escola, ao seguir "uma visão de conteúdo pedagógico como difusão de um saber acumulado pela produção do saber histórico acadêmico" (GUIMARÃES, 2007, p. 103). Nesta direção, "são sugeridos conteúdos que podem ser relacionados aos temas acadêmicos clássicos - 'A conquista europeia na América', 'Organização econômica das colônias americanas, 'A questão da cidadania na sociedade brasileira"” (p. 102).

Nos PCNs, as listas de conteúdos, objetivos e atividades são propostas de modos independentes e "da mesma forma que estão destacadas uma da outra, as antigas três colunas podem ser remanejadas em rede" (GUIMARÃES, 2007, p. 110). Os objetivos poderiam ser desenvolvidos em qualquer conteúdo e atividade, conferindo ao docente a liberdade de escolha do conteúdo histórico. O autor chama atenção para a maior quantidade de conteúdos em relação aos objetivos, mas afirma que não significa tratar-se de uma característica conteudista do documento curricular. A quantidade de conteúdos ministrados não importa nesta abordagem, já que estes assumem a função de alcançar os objetivos do ensino, que no caso do componente de História é pensar historicamente. E, para o desenvolvimento das habilidades do pensar historicamente, "podem ser usados temas da História do Brasil, da América ou de qualquer outra parte e período" (GUIMARÃES, 2007, p. 111). 
Conteúdo, objetivo e atividade aparecem de forma autônoma, mas "se os conteúdos históricos podem ser escolhidos, o mesmo não acontece quanto aos objetivos, que devem ser todos eles conquistados" (p. 115). Em relação ao conteúdo e à função da produção do conhecimento, o autor destaca que "a escola continua sendo socializadora, porém não mais do conhecimento produzido pela academia, mas sim de suas ferramentas e seus procedimentos de pesquisa" (GUIMARÃES, 2007, p. 115). Dessa forma, o conteúdo histórico no documento do PCN tem atributos para desenvolver o pensamento histórico e propiciar ao docente a liberdade de escolha e organização do conteúdo, na perspectiva deste autor.

Maria (2013, p. 49), ao analisar os PCNs, reforça a importância da organização dos conteúdos por Eixos Temáticos como "ruptura com a tradicional estrutura curricular organizada cronologicamente através dos grandes fatos". Destaca o conceito de Experiência, tal como o faz Guimarães (2007), e afirma que esse documento foi construído "a partir de uma ótica na qual a história local e do cotidiano são os eixos teóricos que devem ser tomados como referência para trabalhar a experiência dos estudantes" (MARIA, 2013, p. 90).

Entretanto, ao referenciar o Currículo Estadual, identifica que o conteúdo histórico é organizado "em quatro grandes períodos Históricos: no $6^{\circ}$ ano os estudantes aprendem a Pré-História e a História Antiga; na 6 ${ }^{\text {a }}$ série, História Medieval e Moderna; na $7^{\mathrm{a}}$ e $8^{\mathrm{a}}$ séries, a História Contemporânea" (p. 68). Para a autora, a permanência da organização do conteúdo curricular nas quatro áreas da História - Antiga, Medieval, Moderna e Contemporânea -, reafirma a predominância do modelo quadripartite francês e um descompasso em relação às inovações de organização do conteúdo histórico por Eixos Temáticos.

Para Carvalho Filho (2015, p. 23), as propostas curriculares baseadas em Eixos Temáticos são permeadas por "crescente processo de escolarização de temas e problemas originados na historiografia e em teorias de base cognitivista genericamente denominadas construtivistas ou sócio-construtivistas". Elas assumem, segundo esse autor, como objetivo central, a "inclusão no currículo de temas e conteúdos associados a comportamentos, valores e formas identitárias".

As concepções de tempo e espaço são constantes nos documentos curriculares analisados pelos autores, mas em cada temporalidade a noção apresenta peculiaridades. No documento curricular Programa de $1^{\circ}$ Grau (1982-85), Carvalho Filho (2015, p. 57), afirma que 
se por um lado propiciava inovações na metodologia de ensino - por exemplo, possibilitava abordar simultaneamente a noção tempo-espaço, e articular as histórias locais, regionais e nacionais a dimensões históricas mais amplas, por outro lado, apresentava o risco do "retorno" às narrativas totalizantes e da desconsideração da importância das dinâmicas internas específicas a cada sociedade ou comunidade na produção da realidade.

De acordo com o posicionamento do autor, o potencial dos conceitos ou de generalização do processo dependeria da postura metodológica adotada pelo docente. Já no documento do Movimento de Reorientação Curricular (1989-92), os conteúdos são dispostos em eixos ordenadores da narrativa histórica, que organizam o ensino da disciplina a partir da noção de temporalidades, da memória histórica e das fontes históricas. O autor identifica que os eixos temáticos em torno dos quais se organizavam os conteúdos "eram articulados em função dos objetivos postos para o ensino, orientados pela concepção de ensino-aprendizagem que norteava o Movimento de Reorientação Curricular" (CARVALHO FILHO, 2015, p. 65). Ele descreve, ainda, a metodologia adotada pelo programa, que considerava que:

o ponto de partida e de chegada da investigação histórica pelo aluno e pelo professor seria o tema, em torno do qual haveria a construção dos conceitos estruturantes das disciplinas e que lhe são específicos enquanto campo disciplinar: temporalidades, fonte histórica, fato histórico, agregados a outros como cotidiano e dialogicidade (CARVALHO FILHO, 2015, p. 66).

No terceiro documento analisado por Carvalho Filho (2015), os cadernos e textos com orientações curriculares e didáticas para o Ensino de História, elaborados pela gestão Pinotti/Schneider (2005-2012), percebe-se: mudança na configuração do conhecimento histórico pela articulação entre o presente e o passado; ampliação do conceito de fonte histórica e uso pedagógico dos conceitos de história; e ênfase às competências relacionadas à leitura e escrita (p. 89). Ao mesmo tempo, promove-se o diálogo do tempo presente vivido pelo aluno com a temporalidade do passado através das fontes históricas, justificado pela intertextualidade e a multiplicidade de vozes presentes no texto (p. 91). Dessa forma, o autor conclui que a aprendizagem histórica consiste em análise, interpretação e compreensão dos textos e ressalta a importância da metodologia para utilização das fontes históricas (CARVALHO FILHO, 2015, p. 92).

Ainda sobre os cadernos e textos citados acima, pode-se afirmar que apresentam conteúdos e assumem uma abordagem interdisciplinar:

O trabalho com eixos temáticos pressupõe a ruptura com a percepção de tempo baseado no quadripartismo histórico, linear e progressivo, identificado com a narrativa cronológica que explica o passado como uma sucessão de acontecimentos submetidos a uma relação de causa e efeito. As 
Orientações curriculares sugerem problematizar essa noção de tempo por meio da introdução da idéia de duração ao se trabalhar o conhecimento histórico com os alunos. Discutir com o aluno as mudanças e permanências na vida coletiva ou os diferentes ritmos do tempo na vida cotidiana, apresentar exemplos de sociedades que utilizam (ou utilizaram) diferentes formas de organização temporal, permite a ele relacionar essas formas aos contextos sociais que as produziram (CARVALHO FILHO, 2015, p. 92).

Seguindo a metodologia de comparação entre os documentos curriculares adotadas por Carvalho Filho (2015), o "Programa de $1^{\text {o }}$ Grau (1982-85) mantém o conteúdo do ensino na perspectiva dita tradicional". O autor destaca que:

a disciplina manteve a sua configuração tradicional: estruturação da narrativa em uma perspectiva evolucionista (ideia de progresso como atributo exclusivo da civilização ocidental- cristã); Divisão cronológica da História da humanidade em etapas - antiguidade, medieval, moderna e contemporânea - correspondentes ao crescente predomínio político, econômico e tecnológico da civilização ocidental-cristã sobre outras civilizações e povos; a História da América, único conteúdo novo introduzido no programa da disciplina, aparecia como um desdobramento da expansão marítima européia (perspectiva eurocêntrica) (p. 54).

Essa estrutura foi rompida, segundo o autor, no documento do Movimento de Reorientação Curricular (1989-92), que adota o "tema gerador" como eixo organizador do processo ensino-aprendizagem numa perspectiva interdisciplinar, ao afirmar que: "a interdisciplinaridade possibilitaria ao aluno e aos professores abordarem o tema gerador a partir de problematizações comuns às diversas disciplinas" (CARVALHO FILHO, 2015, p. 59). O autor ressalta a coexistência do currículo disciplinar com a abordagem através do tema gerador, também percebida nos PCNs, "por meio da organização do conhecimento histórico em eixos temáticos, pela criação dos temas transversais e pelo diálogo interdisciplinar com as demais disciplinas do currículo" (p. 89).

Apesar dos PCNs terem sido uma forte referência na elaboração dos currículos municipais e estaduais, estes não incorporaram a organização do conhecimento histórico por Eixos Temáticos, na visão desse autor. Predomina a estruturação da organização do conteúdo histórico de ordem temporal - cronológica, evolucionista e linear - e quadripartite.

A depender da concepção de currículo adotada nos documentos curriculares, algumas propostas incorporam as questões do conhecimento histórico a ser ensinado aos aspectos metodológicos, avaliativos e de aprendizagem da disciplina escolar.

Ao analisar os documentos curriculares do Rio de Janeiro, Rocha (2001b, p. 71) identifica semelhanças entre eles no que concerne à opção pelo Materialismo Histórico e pelo Construtivismo - inicialmente, nos documentos produzidos na década de 80, a psicologia 
genética construtivista, de orientação de Piaget, e mais adiante, na década de 90, uma progressiva adesão às propostas de Vygotsky. Este último, desenvolve um modelo dialético de pensamento, ao propor a percepção das diferenças e semelhanças como método de construção dos conceitos sociais. Dessa forma, alguns pressupostos da psicologia genética se aproximaram das preocupações do componente curricular de História, no entendimento de que o conhecimento histórico se organiza em torno de determinados conceitos-chave construídos historicamente e manifestados nas propostas curriculares (ROCHA, 2001b, p. 60).

Em certa medida, a psicologia genética influenciou a organização dos conteúdos históricos. A teoria da progressão do conhecimento de Piaget é percebida na organização curricular de História do Rio de Janeiro, em razão de postular-se que, na $5^{\mathrm{a}}$ série, os alunos deveriam ser introduzidos aos conteúdos/conceitos introdutórios da disciplina como précondição para continuar os estudos. O problema da pré-condição para prosseguimento dos estudos históricos foi questionado com base na teoria de Vygotsky. As críticas foram incorporadas, ao compreender que os conceitos científicos da disciplina de História estabelecem relação com os conceitos do cotidiano do aluno (senso comum), na produção de conceitos mais complexos no decorrer de todos os anos de ensino, e não apenas no ano inicial do Ensino Fundamental II. Sendo assim, os documentos curriculares da década de 90 expandem a construção histórica dos conceitos, atrelados às experiências dos discentes no decorrer de todos os anos de ensino.

A aposta na relação entre o conhecimento da disciplina escolar e o que vem das experiências dos alunos é explicada na proposta curricular do Rio Grande do Norte (ROCHA, 2001a) pelas escolhas metodológicas da disciplina, que organizam o estudo do cotidiano e a relação entre o particular e o geral, para a construção do conhecimento dos alunos. A proposta curricular sugere que o Ensino de História deverá "procurar a partir do particular da vida cotidiana do aluno as características universais" e estabelecer a "inter-relação entre o presente e o conhecimento já produzido"; a última, só será possível "na investigação de problemáticas que levem o aluno a construir o seu próprio conhecimento" (ROCHA, 2001a, p.158).

Neste contexto, o aspecto metodológico justifica-se no documento pela "preocupação da Proposta em querer que o aluno produza seu conhecimento histórico a partir das suas experiências vividas no cotidiano, usando como método para essa produção a investigação de problemáticas" (p. 159). A aprendizagem é realizada a partir da investigação de problemáticas, o que, no campo da História, se dá pelo seguinte movimento: desenvolvimento de estudos a partir das experiências vividas pelo aluno no seu cotidiano e articuladas ao trabalho com conceitos estruturantes da disciplina (ROCHA, 2001a, p. 164). A 
proposta curricular que objetiva a construção do conhecimento pelos próprios alunos, incorpora as preocupações da Nova História no que se refere à ampliação dos objetos, fontes e problemas do campo historiográfico (p. 157). Essa ampliação insere o aluno como sujeito histórico, em contextos de problemas históricos diversos e fontes para além dos documentos escritos (ROCHA, 2001a, p.160).

Na análise dos PCNs, a referência à aprendizagem é destacada, pela adoção dos novos objetivos, para a valorização da ação do aluno no processo de aprendizagem. Esse caminho se sustenta nos objetivos já apresentados em outros documentos curriculares, expressos em termos tais como identificar, descrever, caracterizar, ordenar, e que passaram também a acionar outras ações, como as de comparar, analisar e relacionar. Para além da ampliação dos objetivos, há a incorporação dos métodos da pesquisa histórica aos métodos de ensino, através do

uso de diferentes fontes de investigação na disciplina, com o intuito de fazer aflorar discursos variados sobre um mesmo tema. Esses procedimentos de ensino valorizam a capacidade interpretativa do aluno e enfatizam o seu saber vivenciado no cotidiano (ROCHA, 2001a, p. 174).

O documento considera as fontes históricas como ferramentas metodológicas para a execução dos objetivos e conteúdos propostos (ROCHA, 2001a, p.182) e, assim, sugere quatro alternativas metodológicas para o estudo da História, que são: o uso do material didático e pesquisas; o trabalho com documentos; a visita a exposições, museus e sítios arqueológicos; e o estudo do meio (p. 182). Segundo a análise do autor, o uso dos documentos históricos é justificado por proporcionar ao aluno a possibilidade de "interpretar informações inerentes ao saber histórico" (p. 183) e, assim, construir suas próprias observações, elaborar questionamentos e produzir sínteses históricas (p. 183). Dessa forma, o uso dos documentos está para além de alcançar os objetivos identitários da disciplina de História, mas também visa a promoção de um pensar histórico a partir das questões investigativas.

Ainda na análise curricular dos PCNs, Rocha (2001a, p. 181-183) destaca que o documento curricular sugere critérios e modos de avaliação e propõe encaminhamentos didáticos, reconhecendo o estudo do meio como uma metodologia de pesquisa e de organização de novos conhecimentos.

Guimarães (2007, p. 86), ao analisar os documentos curriculares paulistas, destaca que a proposta de 1986 enfatiza a participação do aluno no processo de aprendizagem, relacionando-a ao processo de produção de conhecimento, afirmando que o "aluno que 
participa do processo de ensino-aprendizagem, participa da produção do conhecimento. Com ponto de partida a realidade vivida do aluno". O autor identifica contradições epistemológicas nas posturas teóricas adotadas nos currículos da década de 90, que articulam no documento a teoria crítica do currículo ao Construtivismo, em relação à postura do professor. Na primeira, a aprendizagem é centrada na ação docente e, na segunda, ocorreria o deslocamento da ação docente, pois a centralidade da ação estaria no aluno.

Em relação aos aspectos metodológicos, Carvalho Filho (2015, p. 64) destaca a tímida inovação metodológica presente no documento de 1986, em forma de orientações para os docentes em relação a procedimentos teórico-metodológicos. A inovação metodológica de fato, para o autor, é apresentada no documento do Movimento de Reorientação Curricular (1989-92), a partir da ênfase na utilização dos procedimentos da pesquisa historiográfica para a ação em sala de aula. O professor assume o papel de orientador dos alunos para a utilização das fontes históricas e, assim, na produção do conhecimento histórico escolar, através do texto com narrativa histórica. $\mathrm{O}$ autor explica que a metodologia tinha como objetivo:

a apropriação do conhecimento histórico [que] se completava por meio do trabalho com as fontes históricas, matéria prima para a investigação do tema e dos conteúdos. Propunha-se, como principal estratégia, o trabalho com fontes que fizessem referência à História local e ao cotidiano: depoimentos dos moradores, objetos, fotos, cartas, artigos de jornais (locais e não locais), estabelecendo um diálogo com esses documentos, e rompendo com a ideia da força e da preponderância de documentos "oficiais" (ou escritos) (CARVALHO FILHO, 2015, p. 67).

Concluímos que os aspectos metodológicos para o Ensino de História, presentes nos documentos curriculares analisados, guardam correspondência com as preocupações das correntes historiográficas da História Social Inglesa e da Nova História, principalmente no que concerne à problematização da evidência para a produção da narrativa histórica.

A análise da produção curricular do Ensino de História, nos anos de 80 e 90, compreendeu os diversos aspectos do conhecimento histórico escolar. Percebemos, nos documentos curriculares analisados pelos autores, continuidades e transformações em relação ao conhecimento histórico considerado relevante para compor o currículo escolar. Identificamos que as reformas curriculares surgiram no contexto de dois movimentos historiográficos. O primeiro emerge da crítica à historiografia tradicional e o segundo resulta da incorporação dos novos campos historiográficos, entre eles as teorias marxistas, neomarxistas e a Nova História. Em relação às noções de tempo e espaço na organização e escolha do conteúdo histórico, identificamos o não abandono da História balizada pelo tempo 
linear, cronológico e tripartite, apesar da organização de algumas propostas curriculares por Eixos Temáticos ou Eixos Conceituais.

As transformações curriculares foram percebidas nas seguintes frentes: o estabelecimento da história-problema, a partir da problematização dos acontecimentos; a ênfase nas questões de atuação do sujeito histórico, a incluir ações de grupos sociais que não eram objetos da investigação histórica e, consequentemente, a ampliação e complexidade da formação das questões de identidade. Por fim, destaca-se a introdução de novas linguagens associadas ao rigor metodológico da investigação histórica. 


\subsection{O CONHECIMENTO HISTÓRICO NO PROCESSO DE ELABORAÇÃO DA BNCC}

A Base Nacional Comum Curricular, homologada em 2017, compõe a reforma curricular mais recente em andamento no Brasil. O documento foi fruto de um processo de elaboração, no qual versões foram produzidas, analisadas, modificadas, descartadas e retomadas; comissões de elaboração foram alteradas - membros saíram, outros ingressaram e, assim, a cada versão, novos posicionamentos educacionais e políticos eram incorporados.

Não traçamos a trajetória detalhada desse movimento, de permanências e transformações, diante das três versões preliminares e da última versão homologada ${ }^{28}$. Aqui, nos interessou identificar em que medida as críticas, sugestões e contribuições enviadas ao Conselho Nacional de Educação (CNE) foram incorporadas, ou não, no texto da última versão, e até que ponto esses posicionamentos se distanciaram ou aproximaram das propostas curriculares anteriores à BNCC. Para isso, seguimos os questionamentos que orientam a análise documental a partir da identificação dos sujeitos produtores dos documentos, do lugar social ocupado por eles e das propostas e críticas curriculares encaminhadas ao CNE sobre o componente de História.

\subsubsection{Os sujeitos proponentes dos documentos e o lugar social ocupado por eles}

O processo final de elaboração da BNCC é analisado através dos documentos encaminhados ao CNE. A documentação selecionada trata do componente curricular de História e foi produzida por representantes de entidades civis, profissionais e de pesquisa, tais como União Nacional dos Dirigentes Municipais de Educação (UNDIME), Movimento pela Base, Associação Nacional de História (ANPUH) e Associação Nacional de Pós-Graduação e Pesquisa em Educação (ANPEd), e também por representantes individuais, como os professores José Pacheco e Ricardo Moreira, conforme quadro abaixo:

\footnotetext{
${ }^{28}$ Pesquisas que tratam do processo de elaboração da BNCC a partir da análise comparativa entre as versões: Heleno (2017), disponível em: http://tede2.uefs.br:8080/handle/tede/600; Marins (2016), disponível em: http://www.teses.usp.br/teses/disponiveis/48/48134/tde-31082016-150412/; Rodrigues (2004), disponível em: http://www.scielo.br/pdf/his/v23n1-2/a04v2312.pdf.
} 
Quadro 09 - Relação dos documentos encaminhados ao CNE e as abordagens do componente curricular de História

\begin{tabular}{|c|c|c|}
\hline $\begin{array}{lll}\text { Identificação do } & \text { documento } \\
\text { encaminhado ao } & \text { CNE } & \end{array}$ & $\begin{array}{l}\text { Responsável } \\
\text { produção e envio }\end{array}$ & Abordagem \\
\hline $\begin{array}{l}211 \text { Ofício ANPEd no 030/2017 Rio } \\
\text { de Janeiro, } 11 \text { de setembro de } 2017\end{array}$ & ANPEd & $\begin{array}{l}\text { Análise Geral da Base. } \\
\text { Exposição de motivos } \\
\text { contrários à BNCC. } \\
\text { Articulação com Associações } \\
\text { de História. }\end{array}$ \\
\hline $\begin{array}{l}220 \text { Ofício- Rio de Janeiro, } 15 \text { de } \\
\text { janeiro de } 2016\end{array}$ & ANPEd & $\begin{array}{l}\text { Análise Geral da Base. } \\
\text { Exposição de motivos } \\
\text { contrários à BNCC. } \\
\text { Referência ao componente } \\
\text { curricular de História. }\end{array}$ \\
\hline $\begin{array}{l}059 \text { Ofício - Parecer da ANPUH-SC } \\
\text { sobre a terceira versão da Base } \\
\text { Nacional Comum Curricular de } \\
\text { História. } 11 \text { de agosto de } 2017 .\end{array}$ & ANPUH-SC & $\begin{array}{l}\text { Análise da Base. Exposição } \\
\text { de motivos contrários à } \\
\text { BNCC. } \\
\text { Enfase ao componente } \\
\text { curricular de História. }\end{array}$ \\
\hline $\begin{array}{l}070 \text { Ofício - ANPUH-SP na } \\
\text { audiência sobre a Base Nacional } \\
\text { Comum Curricular. Conselho } \\
\text { Nacional de Educação - Comissão da } \\
\text { Base Nacional Comum Curricular. } \\
\text { Audiência pública - Região Sudeste. } \\
25 \text { de agosto de } 2017 \text {. }\end{array}$ & ANPUH-SP & $\begin{array}{l}\text { Análise da Base. Exposição } \\
\text { de motivos contrários à } \\
\text { BNCC. } \\
\text { Enfase ao componente } \\
\text { curricular de História. }\end{array}$ \\
\hline $\begin{array}{l}049 \text { Ofício - Proposta por Ricardo } \\
\text { Moreira. Título: Moral e Cívica e } \\
\text { OSPB na BNCC para mudar e } \\
\text { libertar o Brasil! Audiência pública } \\
\text { do MEC - Base Nacional Comum } \\
\text { Curricular. }\end{array}$ & Ricardo Moreira & $\begin{array}{l}\text { Exposição de motivos } \\
\text { contrários à BNCC. } \\
\text { Referência ao componente } \\
\text { curricular de História. }\end{array}$ \\
\hline $\begin{array}{l}129 \text { Ofício - Brasília, } 11 \text { de setembro } \\
\text { de } 2017\end{array}$ & José Pacheco & $\begin{array}{l}\text { Análise Geral da Base. } \\
\text { Exposição de motivos } \\
\text { contrários à BNCC. } \\
\text { Referência ao componente } \\
\text { curricular de História. }\end{array}$ \\
\hline $\begin{array}{l}069 \text { Ofício - Síntese das leituras } \\
\text { críticas/recomendações } \\
\text { especialistas }\end{array}$ & Movimento Pela Base & $\begin{array}{l}\text { Análise Geral da Base. } \\
\text { Exposição de motivos } \\
\text { favoráveis à BNCC, porém } \\
\text { com críticas } \\
\text { recomendações. } \\
\text { Referência ao componente } \\
\text { curricular de História. }\end{array}$ \\
\hline $\begin{array}{l}131 \text { Ofício - O Desenvolvimento } \\
\text { Integral na Base Nacional Comum } \\
\text { Curricular - Recomendações para } \\
\text { Subsidiar Parecer do CNE - } \\
\text { Conselho Nacional de Educação. } \\
\text { Movimento pela Base. Com } \\
\text { contribuições de: Centro de }\end{array}$ & Movimento Pela Base & $\begin{array}{l}\text { Análise Geral da Base. } \\
\text { Exposição de motivos } \\
\text { favoráveis à BNCC, porém } \\
\text { com críticas } \\
\text { recomendações. } \\
\text { Referência ao componente } \\
\text { curricular de História. }\end{array}$ \\
\hline
\end{tabular}




\begin{tabular}{|c|c|c|}
\hline $\begin{array}{l}\text { Referências em Educação Integral; } \\
\text { Instituto Inspirare; Instituto Ayrton } \\
\text { Senna; CIEB - Centro de Inovação } \\
\text { para a Educação Brasileira; } \\
\text { Sociedade Brasileira de Computação } \\
\text { - SBC, em setembro de } 2017 \text {. }\end{array}$ & & \\
\hline $\begin{array}{l}222 \text { Ofício Presidente da UNDIME } \\
\text { Alessio Costa Lima - Tabuleiro do } \\
\text { Norte-Ceará. Seminário Base } \\
\text { Nacional Comum Curricular em } \\
\text { debate: desafios, perspectivas e } \\
\text { expectativas, realizado nos dias } 20 \text { e } \\
21 \text { de janeiro de } 2016 \text {, em Brasília/ } \\
\text { DF. }\end{array}$ & UNDIME & 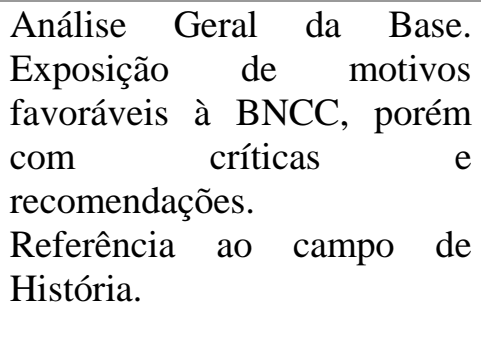 \\
\hline
\end{tabular}

A ANPEd encaminhou dois ofícios ao CNE. O primeiro em janeiro de 2016, no qual faz uma análise geral da primeira/segunda versão da Base e se manifesta contrária ao documento. $\mathrm{O}$ segundo ofício, referente à terceira versão, mantém o posicionamento contrário ao documento. Em ambos ofícios, o componente de História, em certa medida, é contemplado. Fundada em 1978, a associação é a maior e mais antiga na área da educação, com ampla atuação nas cinco regiões do país. No contexto de elaboração da BNCC, o destaque é para o Grupo de Trabalho (GT) de Currículo, atuante desde 1986, e que se fez presente nas discussões do processo de elaboração do documento curricular.

A segunda entidade, ANPUH, fundada em 1961, é a maior associação dos profissionais de História no Brasil, possuindo seções estaduais em todos os estados do território brasileiro e Distrito Federal. A entidade ocupa os espaços de decisões relacionadas ao ofício do historiador nos Conselhos Municipais e Estaduais de Patrimônio Histórico, em Comissões de Educação, etc. Acreditamos que sua atuação em relação às questões curriculares é relevante, principalmente a que expressam historiadores que integram o Grupo de Trabalho Ensino de História e Educação e os que enviaram dois ofícios produzidos pela ANPUH (seções São Paulo e Santa Catarina).

Os documentos encaminhados ao CNE, de números 059 e 070, correspondem, respectivamente, à participação das seções estaduais da ANPUH/Santa Catarina - audiência pública realizada no dia 11 de agosto de 2017, em Florianópolis -, e da ANPUH/São Paulo audiência pública da região Sudeste, realizada no dia 25 de agosto de 2017. Ambos os documentos tratam do componente curricular de História e, em concordância com a ANPEd, se manifestam contrários à BNCC. Na documentação disponibilizada pelo CNE não foram identificadas as manifestações das demais seções da ANPUH nas outras três audiências 
públicas realizadas nas cidades de Manaus, Recife e Brasília. Entretanto, na análise dos vídeos das cinco audiências públicas realizadas pelo $\mathrm{CNE}$, conforme o quadro seis ${ }^{29}$, verificamos a participação das outras regionais da entidade.

No quadro seis, chama a atenção a ausência da ANPUH na primeira audiência pública, realizada em Manaus. A única fala registrada que faz referência específica ao componente curricular de História é a do professor indígena Rosemir Medeiros, integrante do Fórum de Educação Escolar Indígena. O lugar social ocupado pelo docente é o de um profissional que reivindica a construção identitária indígena, temática que permeou fortemente toda essa audiência pública.

A UNDIME, denominada de associação sem fins lucrativos, fundada em 1986, tem como objetivo mobilizar os gestores municipais para a pauta educacional. Possui como parceiros: Itaú Social, Instituto Natura, Fundação Lemann, Fundação Victor Civita, Todos pela Educação, entre outros. A UNDIME enviou ofício ao CNE, assinado por Alessio Costa Lima, que além de representar a entidade no cargo de presidente, também é conselheiro do CNE.

Identificamos, assim, a ligação direta entre UNDIME e CNE e, consequentemente, destas entidades com as instituições privadas já citadas. Evidencia-se, assim, um movimento em bloco com objetivos semelhantes e em trabalho conjunto para elaboração e aprovação da BNCC. No documento, o conselheiro do CNE e presidente da UNDIME, analisa a BNCC em aspectos gerais, expõe motivos favoráveis para aprovação do documento, entretanto sinaliza críticas e recomendações. Faz referência ao campo curricular de História, o que justifica a escolha do documento para análise nesta pesquisa.

Na lógica semelhante, o Movimento Pela Base também faz uma breve análise do documento, mostra-se favorável à proposta curricular, tece críticas e sugestões e referencia o componente de História. A afinação do posicionamento entre as duas instituições - UNDIME e Movimento Pela Base - se explica, pois ambas possuem os mesmos parceiros institucionais, acima listados. Acrescenta-se que o Movimento pela Base nasce de um grupo mais antigo, denominado Movimento Todos Pela Educação, ao qual a UNDIME pertence ${ }^{30}$.

Os últimos dois ofícios apresentados ao CNE foram elaborados por representantes individuais. O primeiro ofício, produzido em setembro de 2017 pelo professor José Pacheco,

\footnotetext{
29 Verificar Quadro 6 - Relação das falas realizadas nas audiências Públicas que contemplam o componente curricular de História, localizado na página 59.

30 Os parceiros da UNDIME foram localizados no sítio da entidade. Disponível em: https://undime.org.br/institucional/parceiros.
} 
da Universidade do Porto-Portugal - que atua em cooperação acadêmica com pesquisadores brasileiros; o segundo por Ricardo Moreira, que não se identifica profissionalmente e também não consta como associado à instituição científica ou como parceiro de entidades sem fins lucrativos. Ambos os profissionais fazem referência ao componente de História e elaboram críticas à BNCC, entretanto, por justificativas e caminhos diferentes, que serão apresentadas no próximo item.

\subsubsection{Propostas para o componente curricular de História da BNCC}

Iniciamos o tópico pela análise dos documentos enviados ao CNE que não foram produzidos por historiadores e suas entidades representativas. Analisamos dois ofícios enviados pela ANPEd ao CNE. O primeiro documento, produzido em janeiro de 2016, conta com a colaboração de outras entidades - Associação Brasileira de Currículo (ABdC), Centro de Estudos Educação e Sociedade (CEDES) e Associação Nacional de Política e Administração da Educação (ANPAE) -; e o segundo documento, elaborado em setembro de 2017, relata a posição da ANPEd sobre a BNCC. Ambos os documentos tecem críticas e propõem contribuições ao documento curricular.

O primeiro documento, elaborado coletivamente, expõe nove motivos "que colocam em evidência que os conceitos de currículo, avaliação, direitos do estudante à aprendizagem e de trabalho do professor em que se fundamenta a BNCC não garantem a valorização e o direito à diversidade" (ANPEd, 2016, p. 02). Dos nove motivos, analisamos o tópico que faz referência aos conteúdos disciplinares do currículo. Segundo o coletivo de entidades, os conteúdos abordados no documento limitam-se às expectativas das comunidades disciplinares e não consideram os saberes da escola e de fora dela. A associação assim se posiciona:

a construção de um documento pautado em objetivos de aprendizagem estabelecidos hierarquicamente por equipes de especialistas nas diferentes áreas, seja sob a forma de manual ou de conjuntos de protocolos, que não tenha como ponto de partida o chão da escola (seria melhor dizer das escolas), não representa o entendimento das comunidades de educadores organizadas nas nossas associações (ANPEd, 2016, p. 05).

Defende ainda que as discussões em relação aos conceitos de currículo, avaliação e direitos de aprendizagem deveriam anteceder qualquer escolha de conteúdo disciplinar. Segundo o coletivo, as discussões curriculares atropelaram as decisões conceituais gerais do campo do currículo e desarticularam as escolhas dos conteúdos das áreas de conhecimento e das realidades escolares. Contesta, assim, a metodologia e a forma de elaboração do 
documento. Ressalta que as entidades não negam a importância da participação dos especialistas das áreas do conhecimento na elaboração da $\mathrm{BNCC}$, porém alertam que a trajetória e a metodologia de elaboração negligenciaram discussões necessárias no campo do currículo.

No segundo ofício, as propostas da ANPEd resultaram das reflexões realizadas em reunião dos 23 GTs que compõem a entidade, com destaque para os que tiveram suas contribuições referenciadas no ofício: GT 02 - História da Educação; GT 07 - Educação Infantil; GT 12 - Currículo e GT 22 - Educação Ambiental. Os posicionamentos dos GTs contemplaram

três níveis de preocupação com a reforma curricular materializada numa base curricular nacional: 1) a própria ideia da necessidade de um currículo comum; 2) a metodologia utilizada para essa construção; 3) os fundamentos conceituais, metodológicos e teóricos explicitados pela terceira versão, que está em debate (ANPEd, 2017, p. 16).

Discutiremos as proposições conceituais, metodológicas e teóricas do ofício, que, em certa medida, dialogam com o componente de História. O documento produzido pela ANPEd alerta que a terceira versão:

Mantém uma lógica conteudinal assinalando assuntos que sequer contemplam os debates atuais nos diferentes campos disciplinares, e retira os conceitos de gênero e de orientação sexual, explicitando a opção por um currículo que se pretende "neutro" e, nesse sentido, articulado com a onda conservadora presente no país (ANPEd, 2017, p. 20).

As duas observações registradas pela entidade se conectam às preocupações no âmbito do componente de História. A primeira observação alerta para o retorno da perspectiva conteudista. A segunda, ressalta a retirada dos conceitos de Gênero e Orientação Sexual que, consequentemente, omite o protagonismo de sujeitos históricos, cujas lutas e resistências encontrariam espaço para serem contempladas na abordagem dos conceitos suprimidos.

O documento encaminhado pela UNDIME, em 2016, é estruturado em duas partes, "uma de considerações gerais quanto à estrutura e ao conteúdo do documento preliminar e outra de contribuições pontuais (inserções, exclusões, alterações de redação) ao texto como um todo" (UNDIME, 2016, p. 02). Em relação às considerações gerais, a entidade toma uma direção diferente da ANPEd, por não propor questionamentos de cunho teórico-epistemológico-metodológicos, mas, sim, no âmbito da implementação da BNCC, por meio da elaboração de instrumentos explicativos sobre a organização e a leitura do documento e sugestão de ações para formação de professores no contexto das propostas da Base. 
As contribuições pontuais versaram sobre as áreas e componentes curriculares Educação Especial, Educação Infantil, Língua Portuguesa, Arte, Educação Física, Matemática, Ciências da Natureza, Ciências Humanas (História, Geografia, Ensino Religioso) - e reúnem as reflexões realizadas pelo Conselho Nacional de Representantes da UNDIME e as secretarias executivas que analisaram o documento da BNCC, a partir das seguintes questões:

1. O que está adequado e deve ser mantido? Justifique; 2. O que falta ou deve ser alterado? Justifique; 3. O que pode ser retirado (excluído) do documento? Justifique; 4 . O que pode ser incluído no documento? Justifique; e 5. Considerações gerais (UNDIME, 2016, p. 04).

Destacamos as questões referentes ao componente de História que, segundo os autores, recomendam:

que se mantenha o rompimento com o eurocentrismo, a partir da história do Brasil, do local para o universal. Em toda área é importante valorizar a história do Brasil, com ênfase especial ao fortalecimento do estudo da história e cultura afro-brasileira (Lei $\mathrm{n}^{\circ} 10.639$, de 9 de janeiro de 2003) e da história e cultura indígenas (Lei 11.645, de 10 de março de 2008) em cumprimento das respectivas Leis e das Diretrizes Curriculares Nacionais (UNDIME, 2016, p. 17).

Prosseguem a análise do documento com ampliações em relação às questões investigativas da disciplina, as noções de tempo e espaço e, por fim, à inclusão dos movimentos sociais no estudo dos processos históricos.

A ampliação das questões relacionadas aos procedimentos da pesquisa em História é sugerida para o sexto ano do Ensino Fundamental. O texto solicita que a questão da investigação histórica ultrapasse a metodologia do uso das fontes, para compreensão da complexidade do processo, através da investigação da ciência ensinada, e sugere "conhecer o conceito de história enquanto ciência e sua importância para o processo de construção do sujeito histórico, no meio ao qual está inserido "(UNDIME, 2016, p. 17). O texto também orienta não apenas o uso, mas a preservação dos documentos históricos. Por fim, completa a articulação entre a investigação histórica e os estudos da diversidade dos sujeitos sociais, ao sugerir a inclusão da ação de "identificar o papel dos movimentos sociais, sociedade civil organizada, outros grupos políticos no processo de redemocratização" (UNDIME, 2016, p. $18)$.

No decorrer do documento, em anos diferentes, os autores também solicitam a ampliação da noção de sujeito histórico ao incluírem as categorias: família, trabalho e 
sociedade. Sugerem a articulação necessária entre as noções de tempo e espaço, ao indicarem, por três vezes, o acréscimo da noção de espaço atrelado ao estudo das diferentes dimensões do tempo. Dessa forma, reforça a necessidade do estudo de múltiplas temporalidades e ampliação do recorte espaço-temporal para o século XXI, abrangendo, assim, as questões do tempo presente (UNDIME, 2016, p. 17-20).

Identificamos no documento da UNDIME preocupações pontuais em relação ao componente de História; pelo aprofundamento das questões da disciplina, acredita-se que o ofício contou com especialistas da área, porém eles não foram identificados na documentação.

O documento produzido pelo Movimento pela Base, segue a mesma linha do ofício encaminhado pela UNDIME. Ambas as entidades não criticam a estrutura geral da BNCC, afirmam a necessidade e finalidade do documento e encaminham sugestões pontuais.

Os documentos do Movimento pela Base, produzidos em setembro de 2017, contam com as contribuições do Centro de Referências em Educação Integral, Instituto Inspirare, Instituto Ayrton Senna, Centro de Inovação para a Educação Brasileira (CIEB) e Sociedade Brasileira de Computação (SBC).

Os documentos centram a atenção no tema do Desenvolvimento Integral na Base Nacional Comum Curricular, elogiam a terceira versão por orientar-se através de uma concepção de educação integral e por definir dez Competências Gerais (Movimento pela Base, 2017a e 2017b). Porém, criticam e sugerem que as Competências Específicas dialoguem diretamente com as Competências Gerais e Habilidades propostas. Os documentos não questionam o teor das Competências Gerais, mas a ausência de uma articulação com os demais itens do texto e recomenda "priorizar as Habilidades que tenham relação direta e assegurem o desenvolvimento das Competências Gerais e das Competências Específicas" (Movimento pela Base, 2017b, p. 02).

Nessa lógica, o documento sugere mudanças nos componentes curriculares da BNCC, indicando para o de História:

Inserir Habilidades capazes de conectar momentos históricos passados com o contexto atual, para que os estudantes possam fazer correlações e utilizar esse legado para o aprendizado sobre o presente;

Equilibrar a quantidade de Habilidades relacionadas às Competências, Conhecimento e Pensamento Crítico, especialmente no $8^{\circ}$ e $9^{\circ}$ anos;

Ampliar as Habilidades relacionadas ao Autoconhecimento (usar história para compreender, expressar e lidar com emoções), Empatia (fomento à relação e colaboração com o outro), Responsabilidade (discussão de temas e desenvolvimento de projetos de intervenção social); 
Buscar maior integração com o Componente Curricular Geografia (Movimento pela Base, 2017b, p. 31).

Ao analisar os encaminhamentos do Movimento Pela Base para o componente curricular de História, percebemos o desejo de alinhar o componente às Competências Gerais e esvaziar as especificidades da ciência ensinada. No primeiro item, o documento trata de momentos históricos, não de processos históricos. Associa-se, assim, a uma visão fragmentada do passado que, segundo os autores, deve se conectar ao contexto atual. Tal assertiva, simplifica a operação espaço e tempo, e nega a complexidade das temporalidades presente, passado e futuro. Também atribui um viés utilitarista ao papel da História, ao cobrar a produção de um legado. A ideia de legado remonta à História exemplar, na qual é escolhido o que deve ser lembrado e transmitido para uma sociedade, em uma perspectiva positivada. Excluem-se, assim, processos históricos considerados não relevantes para uma determinada época e temporalidade.

O segundo tópico, solicita o equilíbrio referente às competências, conhecimento e pensamento crítico. O equilíbrio em questão passa pelo caminho da redução da criticidade, em favorecimento das dimensões física, social e emocional, com o fortalecimento das habilidades de autogestão, autoconhecimento, empatia e responsabilidade. Essa redução no componente de História, coloca em jogo as concepções teóricas da ciência ensinada, que têm como princípio teórico- metodológico a problematização dos processos, dos sujeitos e das fontes históricas, que resultam no ensino crítico dos contextos construídos historicamente.

O não compromisso com a criticidade é reforçado no terceiro ponto, ao deixar claro quais habilidades deverão ganhar espaço. O abandono da criticidade é o ponto de alinhamento para a formação de um cidadão que deve se adequar à sociedade e não questionála, a partir do controle das emoções, da adequação social e da empatia frente às transformações econômicas.

Por fim, a última orientação sugere uma maior integração ao componente curricular de Geografia. Não há direcionamento de como essa articulação deve ser realizada. Porém, as orientações sobre o equilíbrio das habilidades de criticidade e ampliação das habilidades relacionadas à Autogestão, ao Autoconhecimento, à Empatia e à Responsabilidade também são recomendações sugeridas ao componente de Geografia. Caracteriza-se, assim, uma chamada pelo esvaziamento da criticidade no ensino das Ciências Humanas. 
Embora o alinhamento político entre UNDIME (2017) e Movimento pela Base (2017a e 2017b) resulte no parecer favorável à BNCC, percebemos que as entidades dão encaminhamentos distintos em relação às sugestões para os componentes curriculares. No caso da disciplina de História, a UNDIME parece contar com a análise de especialistas da área, ao expressar preocupações em relação aos métodos investigativos da disciplina, das noções estruturantes de tempo e espaço e, por fim, das garantias de inclusão no processo histórico dos movimentos sociais. Já no documento produzido pelo Movimento pela Base, identificamos o esvaziamento dos aspectos do conhecimento histórico, principalmente ao sugerir a redução das habilidades ligadas ao desenvolvimento da criticidade, ao ignorar a complexidade da temporalidade histórica e ao associar a função histórica à transmissão de um legado e ao controle de emoções e condutas "desajustadas" frente às condições vigentes na sociedade.

Após a análise dos encaminhamentos institucionais ao CNE - pela ANPEd, UNDIME e Movimento pela Base -, tratamos de dois posicionamentos individuais que constam nos arquivos do MEC. O primeiro enviado por José Pacheco, docente da Universidade do Porto - Portugal, que encaminhou um texto de quinze laudas ao CNE, denominado: texto-contribuição para debate da BNCC. O autor relata a experiência na elaboração curricular portuguesa e afirma que a "BNCC brasileira se constitui em quase uma réplica da base curricular portuguesa de há vinte anos". O pesquisador aponta que o Brasil poderia evitar o erro cometido por Portugal, de aprovar o documento em forma de lei. Para sustentar essa ideia, sinaliza equívocos encontrados nos documentos da terceira versão, referentes à autonomia escolar, ao modelo de progressão entre as séries, entre outros. Entretanto, identificamos referência ao componente curricular de História. Segundo o autor, os componentes curriculares estão alocados no documento da BNCC sem interações entre si.

Poderia interpelar a BNCC quanto à segmentação da Arte, ou ao isolamento da educação Física, ao ensino das danças, ou das línguas, da História, ou da Geografia, mas perguntaria apenas: que conhecimento de ciências da educação possuem os autores da base curricular? (PACHECO, 2017, p. 10).

Para o autor, a compreensão de certas escolhas curriculares, no caso do isolamento das disciplinas, deve ser antecedida pela preocupação sobre os sujeitos elaboradores do documento. Pacheco afirma que determinadas seleções refletem o desconhecimento dos elaboradores e implementadores da BNCC sobre as ciências da educação. Entre esses, o autor cita os representantes da UNDIME, entidade que possui objetivos de "Promover a ética, a cultura de paz, a cidadania, os direitos humanos, a 
democracia e outros valores universais; Defender a educação básica de qualidade como direito público"31.

Para Pacheco, promover a cidadania através de uma educação básica de qualidade é complexo e exige aprofundamento teórico nas questões das ciências da educação. Indaga o autor:

É possível conciliar a ideia de uma educação para a (e na) cidadania com a divisão dos alunos por turmas e com uma segmentação dos ciclos em anos de escolaridade? Será possível conciliar a ideia de uma educação para a (e na) cidadania com a utilização de manuais didáticos iguais para todos os alunos? Será possível conciliar o respeito pelo aluno-cidadão com a elaboração pelos professores dos chamados "planejamentos de aula", com aulas dirigidas a um hipotético "aluno médio" sem atender a diferentes "ritmos" ou estilos de inteligência? Será possível conciliar a ideia de uma educação para a (e na) cidadania com uma gestão rígida de tempos e espaços educativos, sem resquícios de reconhecimento da existência de imprevisibilidade em espaços e tempos de exercício de uma liberdadesolidariedade responsável? Será possível conciliar a ideia de uma educação para a (e na) cidadania com o trabalho do professor isolado física e psicologicamente na sua sala de aula, sujeito a uma racionalidade que preside à manutenção de um tipo de organização da escola que limita ou impede o desenvolvimento de culturas de cooperação? Será possível que os professores eduquem para a (e na) cidadania, sem referência a projetos suportados numa efetiva autonomia pedagógica? E, quando nos confrontamos com o insucesso dos nossos alunos, não será preciso ultrapassar a atribuição de culpas ao "sistema", não será também necessário interpelar arquétipos que enformam a cultura pessoal e profissional dos professores?

As provocações realizadas por Pacheco (2017, p. 12) põem em jogo a complexidade educacional necessária para alcançar a formação cidadã plena. A cidadania nas diversas esferas - social, cultural, política, econômica - requer ações de reconfiguração, não apenas curricular, mas de vários campos da Educação. A noção de cidadania é relevante para o componente curricular de História, seja pelo retorno e manutenção da disciplina no currículo - após a sua inclusão, juntamente com Geografia, na disciplina de Estudos Sociais -, ou como meio de atribuir sentido ao conhecimento histórico escolar. Dessa forma, a discussão do conceito de cidadania não poderia ser desassociada do debate entre currículo e conhecimento histórico, já que outras contribuições encaminhadas ao CNE irão alicerçar-se em aparatos identitários.

Por fim, o segundo encaminhamento individual, a carta produzida por Ricardo Moreira, intitulada "Moral e Cívica e OSPB na BNCC para mudar e libertar o Brasil!", revela

\footnotetext{
${ }^{31}$ Os objetivos da entidade encontram-se disponíveis em https://undime.org.br/noticia/objetivos.
} 
em seu enunciado o desejo pelo retorno das disciplinas de Moral e Cívica e Organização Social e Política do Brasil (OSPB), que compunham o currículo escolar em períodos anteriores ao investigado nesta pesquisa. $\mathrm{O}$ autor justifica que o retorno das disciplinas, a primeira ministrada às crianças e a segunda aos adolescentes, objetiva formar

cidadãos conhecedores dos seus direitos e deveres perante a sociedade para fazer este Brasil finalmente ter Progresso, bem como, [levá-los a] desenvolverem a consciência para amar e defender de verdade o seu País do crime político organizado que vende suas riquezas minerais a preço de banana, saqueia os cofres públicos e faz do povo escravos da alta carga tributária e dos altos juros bancários que sufocam e nos tornam uma Nação de Terceiro Mundo (MOREIRA, s.d)

O autor destaca o desejo da formação da cidadania alicerçada no discurso de nacionalismo e patriotismo político. Retoma os princípios educacionais difundidos nas décadas de 60-70, ao transcrever o Artigo $2^{\circ}$, do Decreto Lei $\mathrm{n}^{\circ} .869$, de 12 de setembro de $1969^{32}$, que dispõe sobre a inclusão da Educação Moral e Cívica como disciplina obrigatória nas escolas de todos os graus e modalidades dos sistemas de ensino no país. O Artigo $2^{\circ}$ estabelece a finalidade do ensino e o autor, ao transcrever trechos do documento, sinaliza em vermelho frases relacionadas à construção de uma identidade nacionalista, tais como as seguintes expressões: valores da nacionalidade, fortalecimento da unidade nacional, patriotismo, obediência à Lei e formação da consciência cívica do aluno.

O documento não faz referência à retirada da disciplina de História do documento curricular, entretanto, o Parecer $n^{\circ}$ 853/71, que instituiu a Doutrina do Núcleo Comum e estabeleceu as matérias Comunicação e Expressão, Estudos Sociais e Ciências, afetou diretamente as disciplinas de História e Geografia, ao retirá-las do currículo escolar e substituí-las pela disciplina de Estudos Sociais.

Prosseguimos as análises dos ofícios encaminhados ao CNE com o bloco de documentos produzidos pelos historiadores. O ofício produzido pela ANPUH-SC versa sobre a terceira versão da Base Nacional Comum Curricular de História. O documento, com três laudas, realiza uma breve análise das três versões da Base, no que se refere ao currículo para o Ensino de História. Ademais, aponta mudanças entre as versões e a permanência de problemas que devem ser discutidos ${ }^{33}$.

32 O Decreto Lei $\mathrm{n}^{\mathrm{o}}$. 869, de 12 de setembro de 1969 foi revogado em 1993, pelo Decreto Lei n. 8.663. Disponível em: http://www.planalto.gov.br/ccivil_03/decreto-lei/1965-1988/del0869.htm

$33 \mathrm{O}$ processo de elaboração do documento ocorreu entre os anos de 2015 a 2017, refiro-me à parte do Ensino Fundamental - anos finais, objeto da pesquisa, e contou com a produção das três versões. Há estudos que problematizam o processo de elaboração das duas primeiras versões. Dessa forma, priorizamos as contribuições 
O documento apresentado pela ANPUH-SC, sobre a terceira versão, trata da escolha e organização do conhecimento histórico no currículo. Identifica a presença dos conteúdos historiográficos relacionados à História africana, afro-brasileira, indígena e às questões de gênero, porém os conteúdos históricos carecem de aprofundamento e ampliação nas abordagens históricas. Segundo o ofício, a terceira versão da Base apresenta a percepção de "tempo" linear e progressivo, marcada pela forte permanência da História quadripartite, eurocêntrica e cronológica ${ }^{34}$. Em relação às noções de tempo e espaço na organização do conteúdo histórico, o documento aponta a ausência das discussões do conhecimento histórico produzido no tempo presente e da relação do passado com outras temporalidades, não atribuindo sentido espacial e temporal para o Ensino de História. O texto não apresenta defesa de nenhum aspecto da BNCC.

Fica evidente o posicionamento político da entidade, contrário ao governo atual, especialmente na afirmação de que o documento da Terceira versão reflete os problemas relacionados ao projeto político do governo de Michel Temer.

O documento também realiza uma análise geral da BNCC e afirma ter ressalvas em relação ao estabelecimento de "competências", critica o processo de construção da Base denominando-o de não democrático, por recusar as considerações colocadas pela entidade -, e posiciona-se de forma contrária à sua aprovação num movimento desassociado do Ensino Médio. Por fim, conclui que "não somos contrários à existência de uma base, mas sim desta base" (ANPUH-SC, 2017a, p. 02).

Em sintonia com o discurso de crítica à BNCC, a ANPUH-SP posiciona-se, na audiência pública da Região Sudeste, através do documento de $\mathrm{n}^{\circ} 70$. Este, tal como o anterior, possui três laudas e tenta adequar-se ao tempo regimental de três minutos para exposição, conferido à entidade durante a audiência pública. O texto faz uma análise geral da Base e critica: o processo de elaboração, o papel do CNE e a forma de incorporação das contribuições para as versões anteriores do texto e as ações empreendidas para a sua

para a Terceira, para que possamos analisar até que ponto essas contribuições foram acatadas ou silenciadas na versão final.

${ }^{34}$ A avaliação realizada pela entidade, conclui que a primeira versão da base retira do documento o conteúdo histórico referente à História Antiga e à História Medieval, na tentativa de produção de um currículo não eurocentrista. Entretanto, a exclusão da História Antiga e Medieval reforça o eurocentrismo, ao suprimir a história da África anterior ao século XVI, atrelando, assim, a história africana exclusivamente ao protagonismo europeu. O parecer aponta as críticas à retirada desse conteúdo, principalmente as proferidas pelos historiadores africanistas. Ainda assim, o documento revela posicionamento favorável à primeira versão que organizava os conteúdos por abordagens temáticas, apesar dos problemas sinalizados. O componente curricular de História da segunda versão apresenta os conteúdos da História Africana e Indígena através de "temas integradores". Sinaliza a retomada do eurocentrismo, ao adotar o enfoque cronológico e a permanência da chamada "grande narrativa". O documento não apresenta defesa à terceira versão. 
implementação, antes mesmo da aprovação do documento, questionando, assim, o caráter democrático das audiências públicas e a intenção do CNE de não incorporar as suas contribuições na versão final do documento.

O Parecer critica o governo, que nega que a Base seja o currículo, mas avança em diferentes formas de controle do trabalho das escolas e dos professores, bem como a centralidade assumida para a questão da aprendizagem, voltada a atender ao processo de avaliação externa:

a dinâmica que rege a organização progressiva e detalhada em descritores sequenciados apresenta um 'rumo claro': o preparo de estudantes preponderantemente com vistas à aferição de desempenho, em especial aquelas destinadas a avaliações externas (como as provas SARESP, PISA etc.) (ANPUH-SP, 2017a, p. 02).

Em relação ao componente curricular de História, a ANPUH-SP reafirma o compromisso em contribuir com a discussão sobre a BNCC, a partir da concepção do Ensino de História que garanta autonomia ao docente na escolha dos conteúdos e nos procedimentos de ensino, com vistas a fomentar a aprendizagem. A organização dos conteúdos históricos é criticada pela recusa da segunda versão da Base, por considerar que ela mantém uma abordagem eurocêntrica da História. Também critica o estudo da História do Brasil a partir da lógica explicativa do sistema capitalista. Argumenta que o Ensino de História, a partir das abordagens citadas, negará "o entendimento mais amplo da história da sociedade brasileira inserida nas sociedades americanas em sua diversidade cultural, social e econômica" (ANPUH-SP, 2017a, p. 03). O recorte temporal também é alvo de críticas, já que tal delimitação aborda os conteúdos históricos até a década de 1980, impossibilitando assim os estudos do tempo presente e a reflexão sobre o processo político brasileiro na atualidade.

A análise comparativa dos dois documentos produzidos pela ANPUH, representada por suas duas seções estaduais, permite reconhecer a defesa de que o conhecimento do componente curricular de História na BNCC rompa com a abordagem eurocêntrica, adote abordagens temporais para além do tempo cronológico e linear, e que, por fim, seja ampliado o recorte temporal em sua seleção, contemplando as questões da história do tempo presente.

A ANPUH critica as versões preliminares da BNCC, mas não indica claramente as mudanças ou as escolhas curriculares que devem ser realizadas. Notoriamente, no documento da ANPUH-São Paulo (2017a), a análise enfatiza as permanências curriculares 
identificadas entre a primeira e segunda versão, denunciando assim, que as considerações realizadas anteriormente não foram inseridas na terceira versão.

Em diálogo com as propostas curriculares encaminhadas ao $\mathrm{CNE}$, analisamos os vídeos das cinco audiências públicas realizadas pelo CNE, nos pontos que se contempla a discussão sobre a disciplina de História.

Em relação ao componente curricular de História, o Fórum de Educação Indígena (2017) versa exclusivamente sobre a escolha do conteúdo histórico, principalmente os relacionados às questões indígenas tratadas na terceira versão da BNCC. A crítica refere-se à abordagem homogeneizadora das populações indígenas- de modo a negar a diversidade cultural representada pelas diferentes etnias- e à abordagem histórica centrada apenas na temporalidade do passado, negligenciando, assim, a atuação contemporânea indígena na História do tempo presente.

A fala do fórum focaliza especificamente as questões indígenas, o que se explica pelo local social a que pertence. As questões colocadas pela entidade são retomadas pela ANPUH de forma mais ampla nas audiências que se seguiram.

Na segunda audiência, realizada em Pernambuco, a ANPUH-PE (2017) critica o que se apresenta no componente curricular na terceira versão da Base, pelas seguintes questões: eurocentrismo - ênfase à história ocidental, negligenciando as experiências das populações indígenas, africanas e latino-americanas; adoção do processo histórico cronológico - negligência em relação à complexidade temporal da história e restrição ao estudo do passado pelo passado, negando a história do tempo presente; e, por fím, desconsideração das inovações do campo da historiografia - não reconhecimento das diferentes temporalidades e espacialidades no contexto das diferenças sociais e culturais e colaboração com as teses das três raças, do homem cordial e do mito da democracia.

Além das críticas, propõe-se que: sejam integrados na BNCC os conceitos estruturantes da disciplina de História, tais como Historiografia, Fonte, Memória, Duração, Narrativa e Multicausalidade; seja cumprido o que estabelecem a lei $n^{\circ} 10.639 / 2003$ e sua correlata lei $\mathrm{n}^{\mathrm{o}}$ 11.645/2008, que obrigam o Ensino de História e Cultura Afro-Brasileira e Indígena; e sejam afirmados os pressupostos metodológicos da escrita da História para compreensão do saber escolar, como produção científica e social.

Diferentemente das falas apresentadas nas audiências de São Paulo (2017b) e Santa Catarina (2017b), identificamos no vídeo da $2^{\text {a }}$ audiência pública, realizada em Recife, sugestões a fim de selecionar os conhecimentos para o componente curricular de História. Para além das críticas, a fala indica a retirada dos problemas que permanecem, mas também 
sugere acréscimos à proposta da BNCC, tais como: a identificação da fundamentação teórica, no campo das correntes historiográficas; a identificação dos conceitos estruturantes da disciplina de História; a escolha dos temas e conteúdos historiográficos; a organização do conhecimento em relação às noções de tempo/espaço; e a utilização dos processos metodológicos da investigação histórica.

Nesse mesmo caminho, a fala do representante da ANPUH Brasil (2017b), membro do Grupo de Trabalho - Ensino de História e Educação, na quinta e última audiência pública realizada em Brasília, reitera a fala da ANPUH-PE, apontando críticas à terceira versão e sugerindo que:

A BNCC deve apresentar uma proposta para o Ensino de História que contribua para o aprofundamento dos conceitos estruturantes do componente curricular, tais como história, fonte, historiografia, memória, acontecimento, sequência, duração, sucessão, periodização, fato, processo, simultaneidade, ritmos de tempo, medidas de tempo, sujeito histórico, historicidade, identidade, semelhança, diferença, contradição, permanência, mudança, evidência, causalidade, multicausalidade, ficção, narrativa.

- Que, em respeito ao cumprimento dos dispositivos legais e à garantia de uma educação democrática e que respeite as diferenças, sejam garantidos a implantação do Ensino de História da África, da história e cultura afrobrasileira e dos povos indígenas, considerando conteúdos, procedimentos e atitudes.

- Que os acontecimentos contemporâneos e aqueles do passado sejam transformados em problemas históricos a serem estudados e investigados (ANPUH, 2017a, p. 03).

A comparação das falas apresentadas nas audiências de Pernambuco e Brasília mostra a sintonia no tom das sugestões para a BNCC e o avanço, para além das críticas, nos apontamentos apresentados nas falas, assim como nos dois documentos encaminhados ao CNE. Compreendemos o pouco detalhamento do que se propõe nos documentos apresentados, pois foram produzidos para exposição em um tempo regulamentar de três minutos, conforme estabelecido pelo CNE.

No processo de elaboração da BNCC - manifestado pelos documentos encaminhados ao CNE, expresso no documento preliminar da terceira versão e nas falas apresentadas nas audiências públicas - não há a identificação de uma fundamentação teórica no campo das correntes historiográficas. Ao contrário do que se faz nos documentos curriculares produzidos nas décadas de 80 e 90, que propunham a ruptura com o paradigma 
dito tradicional, ao adotar os princípios historiográficos de viés marxista, neomarxista e da Nova História. Identificamos, assim, uma lacuna teórica no campo historiográfico.

A ausência do referencial teórico, na discussão da terceira versão de elaboração curricular, também influencia a ausência dos conceitos estruturantes da disciplina de História (Evidência, Mudança, Narrativa). A omissão é sinalizada e reclamada pelos historiadores, os quais propõem que na versão final do documento o compromisso teórico e conceitual estruturante da disciplina seja expresso no currículo da disciplina de História.

Chama atenção a proposta do Movimento pela Base (2017b), ao sugerir a redução de habilidades de criticidade, referir-se ao conhecimento histórico como legado e simplificar a noção temporal. Tal perspectiva não tem ressonância com abordagens historiográficas adotadas nas reformas curriculares realizadas no período democrático. A combinação de ausência de referencial teórico e negação dos princípios do conhecimento histórico sinaliza um caminho de esvaziamento da História no campo da ciência ensinada.

Em relação à escolha dos temas e conteúdos historiográficos, percebemos a permanência do modelo quadripartite francês - História Antiga, Moderna e Contemporânea atribuindo, assim, o caráter eurocêntrico ao componente curricular, bem como a evidência da não adesão à organização dos conteúdos por temas ou conceitos, tal como proposta pelo PCN e pelos documentos curriculares de São Paulo e do Rio de Janeiro, produzidas na década de 90.

A organização do conhecimento em relação às noções de tempo/espaço parece ser a problemática permanente nas discussões a respeito da reforma curricular do componente de História. Comum nas propostas analisadas anteriormente e no processo de elaboração da BNCC de História, a perspectiva linear, cronológica e evolutiva da História permanece. Entretanto, no processo final de elaboração da BNCC, as questões do tempo presente e da relação necessária do presente com o passado, são ausentes no texto preliminar da terceira versão. As ausências temporais que impossibilitam a localização temporal e espacial do aluno no tempo presente e, por conseguinte, o estabelecimento de relação com qualquer conteúdo histórico do passado, destituem-no das condições para a construção de sentido histórico.

A não utilização dos processos metodológicos da investigação histórica no componente curricular é a queixa recorrente dos historiadores no debate em torno do processo de elaboração da BNCC. Percebemos que propostas curriculares anteriores, nas esferas municipais e estaduais, assim como o PCN de História, recorriam aos procedimentos investigativos da História com objetivos diversos, tais como a construção de um 
conhecimento escolar a partir da ciência ensinada ou como recurso metodológico para a utilização das fontes históricas em sala de aula.

As preocupações em torno do conceito de cidadania aparecem em abordagens diferentes nos documentos produzidos por José Pacheco (2017) e Ricardo Moreira (s.d). O primeiro, com a proposta de cidadania ampla e construída a partir da complexidade escolar. O segundo, em um contexto de retomada das disciplinas Moral e Cívica e OSPB, e seus princípios de cidadania atrelada ao estado nacional, patriótico e homogêneo. A última proposta segue na contramão das discussões realizadas pelos historiadores na atualidade, principalmente no movimento de retorno e legitimação da disciplina de História nos currículos elaborados nas décadas de 80 e 90, para os quais as questões de identidade nacional foram reconfiguradas, a partir das experiências individuais do cotidiano e da diversidade cultural em um mundo global. Pacheco, por sua vez, amplia a ideia de construção da cidadania a partir da ciência da Educação, em um movimento complexo dos agentes escolares, no contexto da escola.

Compreendemos que a análise dos documentos encaminhados ao CNE e as falas registradas nas audiências públicas, referentes ao componente curricular de História, expressaram as propostas e sugestões para o conhecimento histórico no processo final de elaboração da BNCC. Dessa forma, no próximo item, verificaremos, em que medida, as proposições para a versão final rompem ou dão continuidade com os aspectos do conhecimento histórico presente nas reformas curriculares de História anteriores à BNCC. 


\subsection{A BNCC E $\quad$ O COMPONENTE DE HISTÓRIA PARA O ENSINO FUNDAMENTAL - ANOS FINAIS}

No presente tópico analisamos a documentação que trata da versão final da BNCC. Entre os documentos constam o Parecer CNE/CP n n $^{\circ}$ 15/2017, aprovado em 15 de dezembro de 2017 - Base Nacional Comum Curricular (BNCC) e a Resolução CNE/CP nº 2, de 22 de dezembro de 2017 - que institui e orienta a implantação da Base Nacional Comum Curricular.

Inquirimos a documentação a respeito das posições em disputa no processo de concepção da BNCC, as escolhas expressas na versão final deste documento, e por fim, em que medida as escolhas do conhecimento histórico presentes na BNCC rompem ou prosseguem com as propostas e encaminhamentos curriculares para disciplina de História anteriores à sua homologação. Inicialmente, analisamos as escolhas curriculares realizadas pelo CNE que justificam a aprovação do documento final. Em seguida, identificamos as concepções de currículo, conhecimento e competências manifestadas no documento curricular. Avançamos com a análise dos aspectos do conhecimento histórico escolar referente ao componente de História e, por fim, relacionamos as posições defendidas na versão final da BNCC História para o Ensino Fundamental - anos finais com os posicionamentos manifestados nas audiências públicas e nos documentos encaminhados ao CNE. Dessa forma, buscamos contribuir para a compreensão das disputas em torno do campo curricular de História, de modo a identificar as vozes silenciadas e as expressas na versão final da BNCC.

\subsubsection{As escolhas curriculares do CNE: justificativas, impasses e aprovação da BNCC}

O CNE destacou-se pelo protagonismo no processo de elaboração final da BNCC. Realizou, entre junho e setembro de 2017, cinco audiências públicas e recebeu encaminhamentos escritos de apoio, críticas e proposições para a elaboração da versão final da BNCC. Segundo o Conselho, as propostas "foram atentamente analisadas no âmbito do CNE", o que resultou na elaboração de uma planilha com os temas abordados, encaminhada ao MEC, em agosto de 2017, juntamente com as "contribuições obtidas nas audiências públicas, bem como suas análises e as contribuições do Conselho"35.

\footnotetext{
${ }^{35}$ A documentação mencionada no parecer não foi disponibilizada nos arquivos digitais do CNE e MEC. Os documentos são: planilha que compõe o anexo $1 \mathrm{com}$ a sistematização dos resultados das contribuições das audiências e os encaminhamentos recebidos pelo CNE.
} 
O CNE encaminhou ao MEC o Parecer CNE/CP no 15/2017, aprovado em 15 de dezembro de 2017, sobre a Base Nacional Comum Curricular. O documento traça um histórico, com base na legislação educacional, a respeito das menções à elaboração de uma base comum curricular nos textos legais; apresenta a trajetória de elaboração das versões anteriores e justifica as escolhas para compor o documento final.

O Parecer aponta as escolhas curriculares através da justificativa dos saberes que devem ser adquiridos pelos estudantes, sendo eles: conhecimento, habilidades, atitudes e valores (BRASIL, 2017d, p. 25-26). O documento justifica a aquisição do conhecimento disciplinar no campo da cognição, fatos, procedimentos e conceitos, porém, não explica as especificações e articulações dos campos disciplinares escolhidos. Reforça que o currículo não deve contemplar apenas os conhecimentos das disciplinas, julgando essa possibilidade como uma escolha errada, sugere a aquisição de habilidades das práticas cognitivas e socioemocionais, desenvolvimento de atitudes no campo da motivação e disposições pessoais e, por fim, a incorporação dos valores éticos e democráticos. O conjunto de habilidades adquiridas, atitudes desenvolvidas e valores incorporados, segundo o documento, desenvolve a capacidade dos alunos para lidar com as emoções e encontrar soluções para problemas da vida. Para esse fim, estabelece dez competências gerais comuns, as quais analisaremos no próximo tópico (BRASIL, 2017a, p. 26).

O Parecer finaliza com o processo de votação da proposta encaminhada pelo MEC, no qual consta menção às "alterações decorrentes das contribuições recebidas durante os debates desenvolvidos, especialmente nas audiências públicas nacionais e as alterações indicadas pelos conselheiros membros do CNE” (BRASIL, 2017d, p. 31). Das contribuições sugeridas e produzidas pelos debates na Comissão Bicameral do CNE, destacamos a inclusão de temáticas voltadas às populações indígenas, quilombolas e afro-brasileiras e as questões voltadas para a área de computação e tecnologias digitais (BRASIL, 2017d, p. 35).

Sobre os posicionamentos dos conselheiros, podemos concluir que não foram unânimes em relação à aprovação final do texto da BNCC. As conselheiras Aurina Oliveira Santana, Malvina Tania Tuttman e Márcia Angela da Silva Aguiar pediram vistas do processo e votaram contra a aprovação da Base Nacional Comum Curricular nos termos do Parecer, das Resoluções e dos Anexos apresentados pelos conselheiros relatores. A conselheira Tuttman afirma que "os documentos são incompletos e apresentam importantes limitações" (BRASIL, 2017d, p. 43). A conselheira Aurina Oliveira destaca a ausência do Ensino Médio que deveria integrar a BNCC e endossa a conselheira Márcia Angela, que justifica ser contrária ao Parecer porque 
rompe com o princípio conceitual de Educação Básica ao excluir a etapa do Ensino Médio e minimizar a modalidade EJA, e a especificidade da educação no campo; desrespeita o princípio do pluralismo proposto pela Lei de Diretrizes e Bases da Educação Nacional (LDB); fere o princípio de valorização das experiências extraescolares; afronta o princípio da gestão democrática das escolas públicas; atenta contra a organicidade da Educação Básica necessária à existência de um Sistema Nacional de Educação (SNE). [...] o Conselho Nacional de Educação, ao aprovar o Anexo (documento - $3^{\text {a }}$ versão da BNCC) apresentado pelo Ministério da Educação, com lacunas e incompletudes, abdica do seu papel como órgão de Estado; fragiliza a formação integral dos estudantes, além de ferir a autonomia dos profissionais da Educação (BRASIL, 2017d, p. 43).

As alegações das conselheiras não impediram a aprovação do Parecer e da Base Nacional Comum Curricular.

Os conselheiros Alessio Lima, Antônio Cesar Callegari e Gilberto Garcia manifestaram votos favoráveis à aprovação do documento, porém a fala de Callegari presidente da comissão - aponta o campo de conflito nas escolhas curriculares da BNCC. O conselheiro declara que mesmo votando a favor da BNCC, possui reservas quanto ao documento; ele elenca a não inclusão do Ensino Médio na proposta votada e a exclusão das questões de gênero e orientação sexual. Além disso, afirma que "o MEC e a maioria dos membros do CNE acabaram cedendo às pressões das milícias fundamentalistas e ultraconservadoras que se posicionaram contra a existência dessas questões na BNCC" (BRASIL, 2017d, p. 45). Callegari identifica forças externas ao campo educacional, ouvidas e incorporadas em detrimento das emendas por ele enviadas, nas quais solicitava a incorporação das questões de gênero e orientação sexual aos textos, o que não foi acatado. $\mathrm{O}$ conselheiro também encaminhou propostas para o componente de História que não foram atendidas e apontou: "a não aceitação de minhas propostas de sugestões de revisão da proposta de História nos anos finais do Ensino Fundamental, que considero uma concepção meramente factual, linear, cronológica, descontextualizada e alienante” (BRASIL, 2017d, p. 45).

No processo de elaboração do documento da BNCC, segundo Callegari, foi possível negociar inclusões e, dessa forma, elenca as proposições feitas por ele e incorporadas ao documento final, tais como:

a restauração da concepção de educação infantil presente na versão 2 da BNCC, conforme exigiam os principais movimentos brasileiros pela educação infantil; a prevalência dos direitos de aprendizagem e desenvolvimento sobre o conceito de competências (que é uma concepção mais utilitária do conhecimento); a caracterização do documento do MEC como documento técnico complementar, portanto autoral como deve ser, que se vincula à norma na medida em que respeita os termos, conceitos e dispositivos estabelecidos pelo CNE; a explicitação, no parecer, projeto de 
resolução e em todas as partes e componentes do documento técnico da BNCC, que a organização dos objetivos e habilidades nele indicada não deve ser tomada como modelo obrigatório, garantindo-se, assim, a autonomia das escolas e seus professores e sua condição de construir os seus currículos a partir de uma leitura crítica e criativa da Base; a aprovação de todas as emendas relacionadas à inclusão da temática latino-americana por mim apresentadas, antes praticamente ausente da proposta do MEC; do mesmo modo, apoiei outras tantas propostas que foram aprovadas, como a inclusão das orientações sobre educação escolar indígena e quilombola, as referências às novas tecnologias e a reformulação total da proposta de língua portuguesa (BRASIL, 2017d, p. 55).

Percebemos reivindicações e proposições em comum entre as manifestadas por Callegari e pelas conselheiras Aurina Oliveira, Malvina Tuttman e Márcia Angela Aguiar, mas, para elas, os problemas apresentados inviabilizavam a aprovação. Já para Callegari, os problemas do documento seriam corrigidos no "chão da escola e na consciência dos professores” (p. 45). Identificamos que o lugar de fala do conselheiro, na função de presidente da comissão, exige mediar conflitos e, por conseguinte, minimizar o poder normativo e obrigatório alcançado pelo documento e manifestado atualmente no desenvolvimento de políticas educacionais, tais como as que tratam da produção dos currículos locais, da elaboração do material didático e da formação docente.

Retomaremos a fala de Callegari a respeito das proposições para o componente de História, por ele classificada como "factual, linear, cronológica, descontextualizada e alienante", no tópico 3.3.3. Também verificaremos em que medida a questão da inclusão da temática latino-americana, aprovada por emendas apresentadas por ele, foram incorporadas ao componente curricular de História.

\subsubsection{Currículo, Conhecimento e Competências socioemocionais}

A BNCC não é currículo. A definição pela negativa é realizada pelos elaboradores do Parecer encaminhado ao MEC e justificada ao alegar que o documento não abrange as várias dimensões curriculares, entre elas

a da formação dos professores para a gestão da sala de aula e das demais lideranças para a gestão curricular; a de gestão da cultura e do clima que devem presidir os ambientes de aprendizagem; a do tempo e do espaço das aprendizagens (BRASIL, 2017a, p. 26).

Para os elaboradores, a BNCC não é currículo pois não contempla todas as esferas que um currículo, na concepção deles, deveria abranger. Diferentemente, compreendemos que a BNCC compõe uma das dimensões do processo curricular: o currículo prescrito. Este é 
produzido em contextos específicos, por sujeitos com interesses e valores distintos, numa confluência de práticas que resulta em um processo de "configuração, implantação, concretização e expressão de determinadas práticas pedagógicas e em sua própria avaliação, como resultado das diversas intervenções que nele se operam" (SACRISTÁN, 2000, p. 101). Assim, a dimensão do currículo prescrito tem importante papel na definição das condições simbólicas e materiais sob as quais se desenvolverá o processo curricular. Ou seja, nessa perspectiva, currículo não é só o que acontece nas escolas.

Para os autores da BNCC, a definição do documento limita-se ao seu objetivo, o de definir

o conjunto de aprendizagens essenciais que todos os estudantes devem desenvolver ao longo das etapas e modalidades da Educação Básica, constituídas, [...], por conhecimentos, habilidades, atitudes e valores, expressáveis em competências para resolver demandas complexas da vida cotidiana, do mundo do trabalho e do pleno exercício da cidadania (BRASIL, 2017d, p. 26)

Independente da teoria curricular de referência, o que caracteriza o campo do currículo é a discussão acerca do conhecimento a ser ensinado. Todavia, o conhecimento expresso na BNCC é exposto na definição realizada pelo $\mathrm{CNE}$, ao compor um conjunto de aprendizagens essenciais. A ideia de aprendizagem essencial é reforçada pelo MEC, em seu sítio eletrônico:

A Base Nacional Comum Curricular é um documento normativo que define o conjunto de aprendizagens essenciais que todos os alunos devem desenvolver ao longo das etapas e modalidades da Educação Básica. Seu principal objetivo é ser a balizadora da qualidade da educação no País por meio do estabelecimento de um patamar de aprendizagem e desenvolvimento a que todos os alunos têm direito! (BRASIL, 2017c)

O governo define a BNCC como um documento normativo que estabelece o essencial para os alunos aprenderem na escola. Não nega o caráter de currículo, mas também não o assume enquanto tal, e afirma:

a Base deverá nortear a formulação dos currículos dos sistemas e das redes escolares de todo o Brasil, indicando as competências e habilidades que se espera que todos os estudantes desenvolvam ao longo da escolaridade (BRASIL, 2017c).

Assim, compreendemos a BNCC como parte de uma reforma curricular que encontra-se em processo de implementação através da elaboração dos currículos locais, 
produção do material didático e políticas de avaliação e de formação de professores ${ }^{36}$. Sendo assim, ela segue o caminho normativo e "norteador" - do que dita a direção - e determina o que é essencial em várias dimensões e espaços diversos, seja dentro ou fora da escola. Com isso, contraria o que foi dito pelo CNE, quando Callegari refere-se à autonomia docente no "chão da escola" como garantia da possibilidade de contornar os problemas da BNCC. Embora o que aconteça no "chão da escola" tenha importância central no desenvolvimento do currículo, não se pode ignorar a força que as prescrições têm para promover ou desestimular determinados debates e/ou formas de abordagens nas diferentes redes e instituições escolares.

A Comissão Bicameral do CNE, em dezembro de 2017, encaminhou ao MEC o Parecer sobre a BNCC, no qual justifica as escolhas realizadas para o documento curricular. O documento justifica a necessidade de criar a BNCC, amparada pela legislação educacional, demonstrando ser um projeto de longo prazo e que, no ano corrente, estava em vias de conclusão.

As mudanças e substituições de certas "expressões", segundo o documento, são justificadas pelas mudanças ocorridas na legislação ao longo dos últimos anos e incorporadas à BNCC. Justifica-se a equivalência das expressões "direitos e objetivos de aprendizagem" e “competências e habilidades", introduzida na LDB pela Lei $n^{\circ}$. 13.415/2017. No documento da BNCC, o desenvolvimento de competências e habilidades - recorrente no documento dos PCNs (1997) - dá lugar à ideia de "aprendizagens essenciais", como sinônimo de "direitos e objetivos de aprendizagem". Como já se expressa na definição da BNCC, as aprendizagens essenciais versam sobre "conhecimentos, habilidades, atitudes e valores" (BRASIL, 2017d, p. 24).

Entre as mudanças conceituais apontadas pelos elaboradores está a de "formação comum", tratada na LDB, nos arts. 26 e 27. Segundo o documento, os artigos da lei atribuem para uma perspectiva generalista em relação à seleção dos conteúdos curriculares, ao tratar de “diretrizes para a formação comum que não são associadas a conhecimentos disciplinares, mas às dimensões das atitudes e valores e cultura" (BRASIL, 2017d, p. 25). Dessa forma, os elaboradores do documento denunciam uma nova perspectiva associada aos conhecimentos

\footnotetext{
${ }^{36} \mathrm{O}$ processo de implementação da BNCC já se mostra obrigatório a partir das novas diretrizes de formação dos professores, conforme a documentação: Parecer do Conselho Nacional de Educação (CNE) n ${ }^{\circ} 22 / 2019$, que tem como objetivo central a revisão e atualização da Resolução $\mathrm{CNE} / \mathrm{CP} \mathrm{n}^{\circ} 2$, de $1^{\circ}$ de julho de 2015 , que define as Diretrizes Curriculares Nacionais para a formação inicial em nível superior (cursos de licenciatura, cursos de formação pedagógica para graduados e cursos de segunda licenciatura) e que resultou na aprovação da Resolução CNE/CP No 2, de 20 de dezembro de 2019 que define as Diretrizes Curriculares Nacionais para a Formação Inicial de Professores para a Educação Básica e institui a Base Nacional Comum para a Formação Inicial de Professores da Educação Básica (BNC-Formação).
} 
disciplinares:

A primeira categoria do art. 26 da LDB, acima referida, de conteúdos disciplinares, congrega os conhecimentos científicos sobre a natureza das coisas e dos seres humanos, ou seja, conhecimentos factuais, conceituais, procedimentais e metacognitivos, desenvolvidos pelas ciências da natureza e pelas ciências humanas. Estes conhecimentos são adquiridos principalmente em atividades de ensino organizadas com a intenção explícita de possibilitar sua aquisição pelos estudantes (BRASIL, 2017d, p. 25).

$\mathrm{Na}$ perspectiva exposta, o conhecimento da disciplina deve ser abordado nas dimensões dos fatos, conceitos, procedimentos e da metacognição.

Verificamos, no próximo item, de que modo essas questões são abordadas no componente curricular de História. Da mesma maneira, verifica-se ao conhecimento histórico a associação das dimensões das atitudes, valores e cultura, conforme orienta o Parecer do CNE/CP (BRASIL, 2017d, p. 25):

A segunda categoria, referida no art. 27 da LDB, envolve as atitudes, motivações e disposições pessoais que afetam a forma de realização de tarefas, tomada de decisão e escolha de uma maneira de agir. As atitudes são desenvolvidas na interação entre pessoas, ou seja, nas oportunidades geradas pelo convívio social. Também envolvem os valores, que são os saberes necessários para o exercício da cidadania: o respeito aos outros, a introjeção dos valores éticos democráticos e a capacidade de participação. Inclui-se, ainda, o respeito aos valores religiosos, inclusive o respeito àqueles que não professam religiões. No campo dos valores deve-se enfatizar a importância da desconstrução de preconceitos e de discriminações, e enfatizar, também, a tolerância e, acima dela, a aceitação e o reconhecimento do diferente, posicionamentos necessários para se desenvolver a capacidade de solucionar conflitos pelo diálogo e o reconhecimento do outro como igual e diferente.

Diante do exposto, percebemos o deslocamento das preocupações, partindo do conhecimento produzido pela ciência ensinada para a ênfase nas relações sociais do conhecimento.

Destacamos a perspectiva utilitarista do conhecimento curricular, posto em evidência quando se atribui aos conhecimentos, habilidades, atitudes e valores - traduzidos em competências - o objetivo de "resolver demandas complexas da vida cotidiana, do mundo, do trabalho e do pleno exercício da cidadania" (BRASIL, 2017d, p. 26). Para esse fim, são definidas 10 competências gerais, presentes no Parecer homologado pelo CNE/CP (BRASIL, 2017d, p. 26-27) e na introdução ${ }^{37}$ da versão final da BNCC (BRASIL, 2017a, p. 09-10). O

\footnotetext{
${ }^{37}$ A introdução da BNCC (2017a) possui cinco itens: 1. Aprendizagens essenciais; 2. Competências gerais da educação básica; 3. Marcos legais que embasam a BNCC; 4. Os fundamentos pedagógicos da BNCC e 5. O
} 
conhecimento é abordado na primeira competência, que envolve:

valorizar e utilizar os conhecimentos historicamente construídos sobre o mundo físico, social, cultural e digital para entender e explicar a realidade, continuar aprendendo e colaborar para a construção de uma sociedade justa, democrática e inclusiva (BRASIL, 2017b, p. 09).

Na competência acima, o conhecimento construído historicamente está posto e finalizado, cabe ao aluno valorizá-lo e utilizá-lo para entender e explicar a realidade. Não há preocupação com a construção social do conhecimento, mas com a relação entre conhecimento e sociedade. As relações sociais do conhecimento são amparadas em conhecer e explicar a realidade, não em questioná-la, diante dos problemas, contradições e desigualdades sociais, mesmo diante de um quadro que favorece o desenvolvimento de postura acrítica, o aluno é convocado a construir uma sociedade justa, democrática e inclusiva. Essa tríade só poderá ser compreendida e alcançada por completo através do entendimento histórico-crítico dos conflitos sociais que nos permeiam. A competência não sugere transformações sociais, mas a ideia de continuidade e colaboração na construção de um modelo de sociedade não colocado em questão.

As linguagens são destaque da quarta competência geral, não como recurso para a construção de conhecimentos, mas para expressar e partilhar informações, experiências, ideias e sentimentos. As experiências não são abordadas em contextos da diferença e divergência, não se identificam conflitos e tensões, mas sim uma tendência de naturalização, homogeneização e padronização das experiências sociais, ao se afirmar a importância de:

Utilizar diferentes linguagens - verbal (oral ou visual-motora, como Libras, e escrita), corporal, visual, sonora e digital, bem como conhecimentos das linguagens artística, matemática e científica para se expressar e partilhar informações, experiências, ideias e sentimentos, em diferentes contextos, e produzir sentidos que levem ao entendimento mútuo (BRASIL, 2017b, p. 09).

A construção do conhecimento aparece unicamente associada à compreensão, utilização e criação das Tecnologias Digitais de Informação e Comunicação (TDICs), e não quando se refere à investigação e à curiosidade intelectual, conforme veremos adiante na competência dois. As TDICs têm um papel relevante no documento, conforme se verifica na competência cinco:

pacto interfederativo e a implementação da BNCC. O estudo dos elementos introdutórios do documento faz-se necessário para compreender o componente no contexto geral da proposta curricular. 
Compreender, utilizar e criar tecnologias digitais de informação e comunicação, de forma crítica, significativa, reflexiva e ética nas diversas práticas sociais (incluindo as escolares) para se comunicar, acessar e disseminar informações, produzir conhecimentos, resolver problemas e exercer protagonismo e autoria na vida pessoal e coletiva (BRASIL, 2017b, p. 09).

A produção do conhecimento, a criticidade, a resolução dos problemas e o protagonismo dos alunos são frutos atribuídos às TDICs, não aos conhecimentos das disciplinas ensinadas nas escolas. A postura de criticidade também é sinalizada na segunda competência, não na ideia de compreensão do mundo e com base em novas formas de pensar sobre ele, mas em função de criar soluções a partir do conhecimento construído historicamente e disponível. Diz a segunda competência:

Exercitar a curiosidade intelectual e recorrer à abordagem própria das ciências, incluindo a investigação, a reflexão, a análise crítica, a imaginação e a criatividade, para investigar causas, elaborar e testar hipóteses, formular e resolver problemas e criar soluções (inclusive tecnológicas) com base nos conhecimentos das diferentes áreas (BRASIL, 2017b, p. 09).

A competência em si, isolada das demais, induz a caracterizar a proposta curricular como crítica, uma vez que indica a utilização da investigação da ciência e da curiosidade intelectual como caminho necessário para a construção de um conhecimento crítico da cultura escolar. Porém, as demais competências enfatizam as ações de reconhecer e valorizar o que já está posto, aparentemente em caráter inquestionável.

Diz a terceira competência: "valorizar e fruir as diversas manifestações artísticas e culturais, das locais às mundiais, e também, participando de práticas diversificadas da produção artístico-cultural" (BRASIL, 2017b, p. 09). Para as questões culturais, mesmo restritas à dimensão das manifestações artísticas, como apresenta o documento, a valorização e o reconhecimento são limitantes.

As ações de valorizar e reconhecer aparecem em outras duas competências e estão de alguma forma associadas às questões das diversidades (individuais e coletivas, dos saberes, das identidades). As diversidades são tratadas de forma generalista e naturalizada, não se trata das questões de gênero e etnias culturais, mas sugere-se a existência de conflitos que devem ser solucionados de forma harmoniosa. Seguem as competências seis e nove, respectivamente:

Valorizar a diversidade de saberes e vivências culturais e apropriar-se de conhecimentos e experiências que lhe possibilitem entender as relações próprias do mundo do trabalho e fazer escolhas alinhadas ao exercício da cidadania e ao seu projeto de vida, com liberdade, autonomia, consciência crítica e responsabilidade (BRASIL, 2017b, p. 09). 
Exercitar a empatia, o diálogo, a resolução de conflitos de forma harmônica e a cooperação, fazendo-se respeitar, bem como promover o respeito ao outro e aos direitos humanos, com acolhimento e valorização da diversidade de indivíduos e de grupos sociais, seus saberes, identidades, culturas e potencialidades, sem preconceitos de qualquer natureza (BRASIL, 2017b, p. $10)$.

De acordo com o documento, os saberes e vivências culturais da diversidade estão a serviço da compreensão do mundo do trabalho e das escolhas alinhadas ao exercício da cidadania - no caso, da intervenção no mundo. A abordagem das questões da diversidade no documento da BNCC também encontra correspondência com as exposições dos conselheiros no parecer homologado. Na documentação produzida pelos conselheiros, a diversidade é abordada no item "O desafio de uma Educação Básica de qualidade com equidade: uma leitura a partir dos dados oficiais" (BRASIL, 2017d, p. 11), que identifica os problemas sociais estruturantes que o projeto educacional deve enfrentar, e exemplifica usando a problemática das desigualdades raciais. Aponta, ainda, a valorização da diversidade como forma de inclusão social e igualdade nos resultados educacionais.

O projeto educacional brasileiro deve ter como princípios orientadores o enfrentamento de problemas crônicos estruturantes da sociedade brasileira, a exemplo das desigualdades raciais naturalizadas ao longo da história do país. É preciso valorizar a diversidade de nossas matrizes culturais e étnicas indígenas e afro-brasileiras na rotina das escolas, contribuindo para a inclusão social de todos os brasileiros, em especial dessas populações historicamente excluídas. Também é necessário buscar a igualdade nos resultados educacionais entre os diferentes grupos sociais, assegurando a aquisição de aprendizados pelos estudantes em níveis compatíveis com as necessidades contemporâneas de participação plena na sociedade local e global, considerando os laços com os países da América Latina e Caribe.

Para que isso ocorra, há que se buscar a essência da diversidade, ultrapassando o aspecto meramente formal, respeitando e valorizando o patrimônio humano que são as línguas indígenas do território nacional, suas culturas e epistemologias. Do mesmo modo, os saberes quilombolas e os elementos culturais afro-brasileiros e das demais populações que habitam o Brasil. Ao lado das matrizes epistêmicas eurocêntricas, é preciso respeitar, valorizar e incorporar os saberes indígenas e quilombolas a fim de que se tornem realidade outras possibilidades de interculturalidade $\mathrm{e}$ transdisciplinaridade na escola brasileira.

Um projeto de nação só pode prosperar com a inclusão de todos os segmentos populacionais na busca por uma sociedade fraterna que oferece as condições básicas para que todos possam desenvolver as suas potencialidades. Nesse sentido, a educação cumpre papel essencial (BRASIL, 2017d, p. 11).

Diante do exposto pelo CNE, o estudo das diversidades tem uma dupla função: resolver problemas estruturais do país - como a desigualdade racial - e promover a igualdade 
nos resultados educacionais. Após a leitura do trecho sobre diversidade e os problemas a resolver, temos mais inquietações do que considerações a fazer. É função da escola e responsabilidade do aluno, isoladamente, a resolução de problemas sociais tão complexos? É possível que o acesso ao conhecimento escolar, através dos estudos sobre a diversidade, pelo caminho da interculturalidade e transdisciplinaridade, leve à igualdade racial e à equidade educacional? Em que medida e como o componente curricular de História é posto nesse diálogo?

Antecipo aqui as preocupações referentes ao componente de História, uma vez que a LDB de 1996 - versão atualizada em 2017 - nos artigos 26 e 26-A (BRASIL, 2017b, p. 20-21) incorpora a obrigatoriedade do ensino da história e cultura afro-brasileira e indígena ${ }^{38}$, ao determinar:

Art. 26. $\S 4^{\circ} \mathrm{O}$ ensino da História do Brasil levará em conta as contribuições das diferentes culturas e etnias para a formação do povo brasileiro, especialmente das matrizes indígena, africana e europeia.

Art. 26-A. Nos estabelecimentos de Ensino Fundamental e de ensino médio, públicos e privados, torna-se obrigatório o estudo da história e cultura afrobrasileira e indígena.

As questões da diversidade e o estudo das culturas africanas, afro-brasileiras e indígenas (apresentadas nas competências gerais) são retomadas na análise dos aspectos do conhecimento histórico curricular, associadas à função estabelecida para a escola e à formação esperada para o aluno.

Ao dar continuidade à análise do que é essencial para a BNCC, expresso nas dez competências gerais, identificamos a predominância das competências socioemocionais nos itens sete, oito, nove e dez. Na competência oito, o aluno é posto no lugar de cuidar de si, principalmente das suas emoções: "Conhecer-se, apreciar-se e cuidar de sua saúde física e emocional, compreendendo-se na diversidade humana e reconhecendo suas emoções e as dos outros, com autocrítica e capacidade para lidar com elas" (2017a, p. 10). O aprendiz deve pôr suas emoções em análise, para assim compreendê-las, apreciá-las, reconhecê-las e criticá-las. Sugere-se, assim, que as emoções se expressam em comportamentos desejáveis ou não. Por isso, a empatia e a resiliência são os destaques das competências nove e dez:

\footnotetext{
${ }^{38}$ Lei $\mathrm{N}^{\circ} 10.639$, de 9 de janeiro de 2003. Altera a Lei no 9.394, de 20 de dezembro de 1996, que estabelece as diretrizes e bases da educação nacional, para incluir no currículo oficial da Rede de Ensino a obrigatoriedade da temática "História e Cultura Afro-Brasileira", e dá outras providências.
} 
Exercitar a empatia, o diálogo, a resolução de conflitos de forma harmônica e a cooperação, fazendo-se respeitar, bem como promover o respeito ao outro e aos direitos humanos, com acolhimento e valorização da diversidade de indivíduos e de grupos sociais, seus saberes, identidades, culturas e potencialidades, sem preconceitos de qualquer natureza (BRASIL, 2017a, p. $10)$.

Agir pessoal e coletivamente com autonomia, responsabilidade, flexibilidade, resiliência e determinação, tomando decisões com base em princípios éticos, democráticos, inclusivos, sustentáveis e solidários (BRASIL, 2017a, p. 10).

A ideia de valorização permeia o campo do positivo e do negativo, dificultando a compreensão da diferença, já que se ancora na superficialidade e no ato estereotipado. A ação de compreender supera a adjetivação, ao implicar o conhecimento do outro no contexto social e cultural.

A resiliência no contexto da compreensão dos processos históricos se aproxima da ideia de disposição em compreender as pessoas do passado no contexto da diversidade, compreendendo-as como "seres humanos com direito ao mesmo respeito que exigimos para nós" (LEE, 2003, p. 21). Entretanto, a competência da resiliência se distancia das questões da diversidade e interculturalidade, ao sugerir o controle das emoções e do comportamento diante de uma situação de conflito ou mudança. Segundo o Instituto Ayrton Senna (IAS) - um dos apoiadores da BNCC -, "resiliência emocional é a capacidade de enfrentar as dificuldades da vida, aprender com elas e ganhar mais força para vencê-las. Isso é muito importante quando precisamos regular emoções desagradáveis” (IAS, 2020, p. 07). Na definição realizada pelo IAS, publicada em material pedagógico de ampla divulgação, é evidente a ideia de controle das emoções e a sua classificação em aceitáveis ou não.

Freitas (2014) alerta para o interesse dos empresários do capital econômico nas questões educacionais, principalmente as que pautam a formação dos estudantes. $\mathrm{O}$ autor denomina os membros desse grupo de reformadores empresariais da educação, que objetivam "resolver a contradição entre a necessidade de padronizar e liberar um pouco mais de acesso ao conhecimento sem com isso perder o controle político e ideológico da escola" (FREITAS, 2014, p. 1089). Esse controle é percebido em várias instâncias de sua atuação, seja ao assumirem a direção do processo educativo - através da forte participação na elaboração da BNCC, dos materiais de implementação e das políticas de formação docente - ou, como bem vimos, no fomento às ações voltadas ao desenvolvimento do controle emocional e comportamental dos alunos, com vistas ao mundo do trabalho. 
O mundo do trabalho ganha tons de inovação curricular ao incorporar as competências socioemocionais, que focam na ação do indivíduo (aprendiz) e objetivam o desenvolvimento da produtividade com princípios utilitaristas e práticos. A resiliência imprime uma marca utilitarista ao propor a adaptação do indivíduo às demandas sociais, independentemente do contexto social em que ele se encontra. Também se responsabiliza o aprendiz, que mediante a informação disponível, deve ter autonomia e discernimento na tomada de decisões, como expressa a competência sete:

Argumentar com base em fatos, dados e informações confiáveis, para formular, negociar e defender ideias, pontos de vista e decisões comuns que respeitem e promovam os direitos humanos, a consciência socioambiental e o consumo responsável em âmbito local, regional, com posicionamento ético em relação ao cuidado consigo mesmo, com os outros e com o planeta (BRASIL, 2017a, p. 09).

Nesta competência fica evidente que o protagonismo do aluno também é construído a partir da sua responsabilização pela aprendizagem e pela resolução de problemas sociais. O protagonismo do indivíduo é estruturado e permeado pelas competências socioemocionais. Para deixar mais evidente essa relação e a possibilidade de executá-la no "chão da escola", o Instituto Ayrton Senna produziu e publicou um estudo ${ }^{39}$, no qual apresenta a relação entre as macrocompetências e as 10 competências gerais da BNCC.

O que percebemos, com a análise das competências socioemocionais no documento da BNCC, é a responsabilização da escola pela resolução de múltiplas demandas sociais e a formação do aluno para o mercado de trabalho, regido pelo capital econômico. Freitas (2014, p. 1089) identifica as preocupações do capital no contexto educacional contemporâneo:

Como liberar um pouco mais de conhecimento para as camadas populares sem abrir mão do controle ideológico da escola, sem correr o risco de eventualmente abrir espaço para as teorias pedagógicas mais progressistas, comprometidas com as transformações da escola para além da versão tecnicista e escolanovista? Como, em um quadro de escassez de mão de obra

\footnotetext{
${ }^{39}$ Ideias para o desenvolvimento de competências socioemocionais: resiliência emocional. Segundo o estudo, as cinco macrocompetências tratam da abertura ao novo, amabilidade, autogestão, resiliência emocional e engajamento com os outros. Essa matriz se desdobra em 17 competências socioemocionais: autogestão: determinação, organização, foco, persistência e responsabilidade; engajamento com os outros: iniciativa social, assertividade e entusiasmos; amabilidade: empatia, respeito e confiança; resiliência emocional: tolerância ao estresse, autoconfiança e tolerância à frustração; e, por fỉm: abertura ao novo: curiosidade para aprender, imaginação criativa e interesse artístico. Publicado em 2020 e disponível em:

https://institutoayrtonsenna.org.br/content/dam/institutoayrtonsenna/documentos/instituto-ayrton-sennamacrocompetencia-resiliencia-emocional.pdf?utm_source=site\&utm_medium=hub-1507. Acesso em: 20 de fevereiro de 2021.
} 
barata, incorporar cada vez mais as camadas populares na escola básica, submetendo-as à preparação para o mercado de trabalho?

A escolha frente ao impasse reconhecido por Freitas, decerto, foi o deslocamento da centralidade do conhecimento disciplinar para as competências socioemocionais e do ensino para a aprendizagem.

O primeiro, da centralidade do conhecimento disciplinar para as competências, acontece quando o papel da escola se afasta da ideia de promover o acesso dos alunos a "explicações confiáveis sobre o mundo", criando assim novas formas de pensar e ir além das experiências mais imediatas (YOUNG, 2007, p. 1294). No lugar disso, ganham centralidade as preocupações com as competências socioemocionais - expressas nas habilidades, atitudes e valores afirmados na BNCC. Nessa perspectiva, a ênfase não recai sobre a formação intelectual dos aprendizes - conforme defende Young -, mas na resolução das "demandas complexas da vida cotidiana, do mundo do trabalho e do pleno exercício da cidadania" (BRASIL, 2017a, p. 13).

Em relação às reformas curriculares que objetivam resolver problemas sociais, Young (2011, p. 611-612) alerta para o perigo dessa escolha: "quanto mais nos focamos na possibilidade de um currículo reformado resolver problemas sociais e econômicos, tanto menos é provável que esses problemas sejam tratados em suas origens, que não se encontram na escola”. Somada a essa impossibilidade da escola em resolver os problema sociais, já que suas origens não se encontram nela, Laval (2019, 2019, p. 45) aponta as contradições nos princípios educacionais da escola de modelo neoliberal, ao afirmar que:

não conseguimos ver como a escola sozinha poderia resolver a 'degradação do ambiente social', isto é, as desigualdades, a insegurança social, a crescente anomia, a delinquência, etc. Não conseguimos ver, sobretudo, como uma escola com o mesmo motor da sociedade de mercado poderia impedir o efeito de dissolução causado pelo curso atual do neoliberalismo.

A contradição se estabelece no conflito de objetivos da escola neoliberal, que ora visa formar assalariados adaptáveis às constantes transformações e instabilidades econômicas, ora convoca os aprendizes a resolver os problemas do cotidiano, causados pelo próprio contexto neoliberal, ignorando suas idiossincrasias.

O segundo deslocamento promovido pela lógica neoliberal - do ensino para a aprendizagem - é ressaltado por Young (2016, p. 28), ao afirmar que a noção de educação foi tomada pela noção de aprendizagem no campo de políticas e linguagens curriculares. $\mathrm{O}$ autor alerta sobre o caráter sedutor dessa paulatina substituição: "a aprendizagem é considerada aberta, boa, progressiva de oportunidades para novos aprendizados". Esse deslocamento se 
explicita quando a proposta curricular prioriza o aluno e as experiências vividas no seu imediato, mas não avança para além disso, assumindo um viés utilitarista e prático, voltado a adequar o aprendiz ao mercado de trabalho sem questionar o que se aprende e para que, mas objetivando que o aluno esteja sempre disposto a aprender e emocionalmente preparado para resolver ou/e se adequar aos problemas econômicos e sociais.

A abordagem da tríade currículo, conhecimento e competências socioemocionais pretendeu favorecer a compreensão das escolhas teóricas que fundamentam o documento da BNCC. No próximo item, focalizamos o componente curricular de História, na seleção do conhecimento histórico e em diálogo com as escolhas curriculares até aqui apresentadas.

\subsubsection{Aspectos do conhecimento histórico na BNCC do Ensino Fundamental - anos finais}

A BNCC (2017a) apresenta o Ensino Fundamental, obrigatório, organizado em nove anos e dividido em dois blocos: Ensino Fundamental - anos iniciais; e Ensino Fundamental - anos finais. Os componentes curriculares estão agrupados em áreas de conhecimento e o componente de História compõe, juntamente com o de Geografia, a área de Ciências Humanas.

A organização curricular da BNCC é justificada por visar garantir o desenvolvimento de competências gerais, da área de estudo e dos componentes curriculares. A articulação desse conjunto de competências explica a permanência da área do conhecimento (Ciências Humanas) e do componente disciplinar (História) no currículo, bem como as escolhas teórico-metodológicas, conceituais e, por fim, os demais aspectos do conhecimento apresentados na versão final da BNCC.

Sabendo que os componentes de História e Geografia compartilham sete competências específicas da área de Ciências Humanas, optamos em analisar as competências específicas do componente de História, também em número de sete, conjuntamente com as competências da área. Ambos os conjuntos contemplam categorias, noções, habilidades e objetivos semelhantes, por exemplo, as noções de tempo e espaço de que tratamos anteriormente. Quando oportuno, relacionamos as competências da área das Ciências Humanas e do componente de História com as Competências Gerais, apontando aproximações e distanciamentos.

A justificativa para a permanência da área de Ciências Humanas no currículo, e por conseguinte da disciplina de História, está em sintonia com as competências gerais da BNCC. O texto de apresentação da área de Ciências Humanas estabelece como objetivo de 
ensino a formação do aluno para "melhor compreensão do mundo, não só favorecendo o desenvolvimento autônomo de cada indivíduo, como também os tornar aptos a uma intervenção mais responsável no mundo em que vivem” (BRASIL, 2017a, p. 352). A tríade compreensão do mundo, autonomia do indivíduo e intervenção no cotidiano é detalhada ao longo do texto.

Em relação à compreensão do mundo, o documento destaca a importância da formação ética e a consolidação de um sentido de responsabilidade amparado nos direitos humanos, no respeito ao meio ambiente e à coletividade. A formação para a cidadania, marca da concepção da escola republicana, não é abandonada, mas alocada para o contexto atual do neoliberalismo, uma vez que age em nome dos valores e ações sociais específicas. Isso pode ser associado ao que aponta Laval (2019, p. 19), ao afirmar que o neoliberalismo "utiliza em geral vias técnicas e se apresenta com frequência com as melhores intenções éticas".

Assim, o documento da BNCC ressalta valores sociais, tais como solidariedade, participação e protagonismo, voltados ao bem comum e às questões referentes à preocupação com as desigualdades sociais. Essa preocupação é sinalizada uma vez nos textos da área de Ciências Humanas e no componente curricular de História. Outros termos, como "contradições" políticas, econômicas e sociais (BRASIL, 2007a, p. 396) e "tensões" - sociais, culturais, políticas e econômicas (BRASIL, 2007a, p. 398) -, são expressões que se aproximam de uma sociedade contemporânea, marcada pelas desigualdades que, porém, são tratadas de forma isolada e naturalizada.

No campo da autonomia do indivíduo, o texto das Ciências Humanas destaca o papel dos conhecimentos específicos da área e seu conjunto de objetos de conhecimento no desenvolvimento de habilidades para pensar diferentes culturas e sociedades, em contextos históricos e geográficos diferentes. As competências socioemocionais são indicadas no ensino das Ciências Humanas ao se promover "explorações sociocognitivas, afetivas e lúdicas capazes de potencializar sentidos e experiências com saberes sobre as pessoas, o mundo social e natureza" (BRASIL, 2007a, p. 352).

O texto ainda sugere que tais sentidos e experiências devam contribuir para adensar os conhecimentos, de modo que o aluno seja capaz de participar do mundo social e refletir sobre questões sociais, éticas e políticas. Não há indícios do desejo de transformação social, nem uma discussão sobre as causas e problemas associados às desigualdades sociais. No campo restrito da reflexão, o texto informa que a área de ensino das Ciências Humanas contribuirá para formação de uma autonomia intelectual, a partir de "bases para uma atuação crítica e orientada por valores democráticos" (BRASIL, 2007a, p. 352). 
A reflexão a partir das experiências humanas também é indicada na articulação das categorias dos conhecimentos disciplinares, quando se afirma que:

Cabe, ainda, às Ciências Humanas cultivar a formação de alunos intelectualmente autônomos, com capacidade de articular categorias de pensamento histórico e geográfico em face do seu próprio tempo, percebendo as experiências humanas e refletindo sobre elas, com base na diversidade de pontos de vista (BRASIL, 2007a, p. 352).

De acordo com a transcrição documental, as categorias históricas (tempo, espaço, contexto, entre outras) devem promover a percepção e a reflexão sobre as experiências humanas. Já o desenvolvimento das habilidades para o uso das diferentes linguagens (oral, escrita, cartográfica, estética, técnica) possibilitará “o diálogo, a comunicação e a socialização dos indivíduos, condição necessária tanto para a resolução de conflitos quanto para um convívio equilibrado entre diferentes povos e culturas". Conclui-se que "o desafio é grande, exigindo capacidade para responder de maneira crítica, propositiva e ética aos conflitos impostos pela história" (BRASIL, 2017a, p. 354).

Percebemos que o conhecimento disciplinar da área das Ciências Humanas, com seus conceitos estruturantes, não foi abandonado, mas mobilizado para fomentar o desenvolvimento de habilidades sociais (Diálogo, Comunicação e Socialização), consideradas necessárias à resolução de conflitos - escolha curricular já apontada como contraditória e não factível.

Nas competências da área das Ciências Humanas, o protagonismo do aluno é destaque nas competências dois, três e seis. Na competência dois, afirma-se que o aluno, a partir dos conhecimentos da área, é formado para "intervir em situação do cotidiano e se posicionar diante de problemas do mundo contemporâneo" (BRASIL, 2017a, p. 355). Na terceira competência, o aluno deve identificar, comparar e explicar a intervenção dos sujeitos na natureza e na sociedade, chegando a "propor ideias e ações que contribuam para a transformação espacial, social e cultural, de modo a participar efetivamente das dinâmicas da vida social" (BRASIL, 2017a, p. 355). Por fim, a sexta competência destaca o "protagonismo voltado para o bem comum e a construção de uma sociedade justa, democrática e inclusiva" (BRASIL, 2017a, p. 355). As competências da área enfatizam o protagonismo e o posicionamento do aluno para intervir na sociedade.

No componente de História, o objetivo da disciplina visa a formação do aluno para se posicionar e intervir no mundo contemporâneo. Entretanto, não há menção à resolução de demandas complexas da vida cotidiana - indicada no texto geral da BNCC - e nem à 
resolução de conflitos, conforme sinaliza o texto da área das Ciências Humanas. De acordo com a primeira competência específica do componente, cabe ao Ensino de História:

Compreender acontecimentos históricos, relações de poder e processos e mecanismo de transformação e manutenção das estruturas sociais, políticas, econômicas e culturais ao longo do tempo e em diferentes espaços para analisar, posicionar-se e intervir no mundo contemporâneo (BRASIL, 2007a, p. 400).

No texto da BNCC História, não se especifica para qual finalidade se volta a intervenção. A relevância da disciplina é reiterada pela menção ao seu papel na formação dos alunos: "a História como um saber necessário para a formação das crianças e jovens na escola" (BRASIL, 2017a, p. 395), a partir das questões do tempo presente. Destaca-se, também, a sua função de "estimular a autonomia de pensamento e a capacidade de reconhecer que os indivíduos agem de acordo com a época e o lugar nos quais vivem, de forma a preservar ou transformar seus hábitos e condutas" (BRASIL, 2017a, p. 398) Conclui-se que o contato com "uma grande diversidade de sujeitos e histórias estimula o pensamento crítico, a autonomia e a formação para a cidadania" (BRASIL, 2017a, p. 398). Assim, a formação para a cidadania não é referida como objetivo do Ensino de História, que funciona como um estímulo à percepção da diversidade e ao desenvolvimento do pensamento crítico.

No documento do componente curricular de História, a autonomia do aprendiz é alicerçada na epistemologia da ciência ensinada, argumentada a partir das seguintes questões:

a natureza compartilhada do sujeito e do objeto do conhecimento, o conceito de tempo histórico em seus diferentes ritmos e durações, a concepção de documento como suporte das relações sociais, as várias linguagens por meio das quais o ser humano se apropria do mundo. Enfim, percepções capazes de responder aos desafios da prática historiadora presente dentro e fora da sala de aula (BRASIL, 2017a, p. 398).

Dessa forma, espera-se que o conhecimento histórico, em sua prática historiadora:

seja tratado como uma forma de pensar, entre várias; uma forma de indagar sobre as coisas do passado e do presente, de construir explicações, desvendar significados, compor e decompor interpretações, em movimento contínuo ao longo do tempo e do espaço. Enfim, trata-se de transformar a história em ferramenta a serviço de um discernimento maior sobre as experiências humanas e as sociedades em que se vive (BRASIL, 2017a, p. 399).

O conhecimento histórico cumpre o papel de ferramenta para discernir as experiências humanas. A generalidade do termo e a ausência da problematização promovem o risco de adjetivá-las e classificá-las em experiências melhores ou piores, e supõe escolher 
quais as experiências válidas de serem lembradas ou, no caso, estudadas, a partir do critério de diferenciação e separação adotado.

Diante do exposto, percebemos que não há na BNCC um abandono do conhecimento histórico, mas um deslocamento, no qual o conhecimento histórico escolar é posicionado em função do desenvolvimento das competências socioemocionais. Embora esse movimento fique mais explícito na área de Ciências Humanas do que no componente de História. Poderia se dizer que o campo acaba tendo a força para manter uma visão mais crítica do Ensino de História, mesmo em um documento que se dirige mais às competências socioemocionais. Uma vez que o ensino das Ciências Humanas, com ênfase para História, deve, acima de tudo, contribuir para desenvolver habilidades sociais - como estimular a formação ética e o sentido de responsabilidade, para, assim, valorizar os direitos humanos, respeito ao ambiente e à própria coletividade, além de fortalecer os valores sociais, tais como solidariedade, participação e protagonismo - e, em um plano secundário, preocupar-se com as desigualdades sociais.

Em segundo plano, portanto, surge a preocupação com a formação intelectual dos alunos, a partir da articulação das categorias de pensamento histórico e geográfico (BRASIL, 2017a, p. 352). Esse reposicionamento de prioridades do conhecimento da disciplina para as competências socioemocionais, permeia a definição dos objetivos do Ensino de História e sua presença no currículo escolar. A seguir, verificamos em que medida os demais aspectos do conhecimento histórico atendem ao deslocamento identificado.

As correntes historiográficas escolhidas na documentação curricular não necessariamente limitam as escolhas teóricas e metodológicas, mas, em certa medida, legitimam as escolhas e usos das noções e conceitos do componente. O próprio texto da BNCC História menciona a necessidade do conhecimento de referências teóricas para compreender a complexa relação das noções temporais entre passado/presente e também, “trazer inteligibilidade aos objetos históricos selecionados” (BRASIL, 2017a, p. 395).

Para isso, a proposta curricular da BNCC História não recorre a uma determinada corrente historiográfica. $\mathrm{O}$ texto discute as noções de relação tempo/espaço e documentos históricos a partir dos estudos do historiador Ulpiano Bezerra de Menezes (1998), que enfatiza a necessidade de uso de critérios e procedimentos para análise dos objetos e defende que

o historiador não faz o documento falar: é o historiador quem fala e a explicação de seus critérios e procedimentos é fundamental para definir o 
alcance de sua fala. Toda operação com documentos, portanto, é de natureza retórica (MENEZES, 1998 apud BRASIL, 2017a, p. 395)

A escolha teórica, transcrita acima e publicada integralmente no texto da BNCC História, compreende que a relação tempo/espaço e as relações sociais que a produzem são alcançadas pelo processo de análise do uso do objeto ou das questões a serem estudadas. Dessa forma, o objeto torna-se o conceito estruturante da disciplina de História na BNCC.

O tratamento do objeto como potencial de evidência histórica é resultante dos estudos da cultura material, que objetivam superar a visão tradicional positivista, na qual os objetos não eram considerados fontes históricas. A abordagem curricular da BNCC História considera a multiplicidade das tipologias das evidências históricas, ao considerar essencial e relevante a análise dos documentos escritos, iconográficos, materiais e imateriais.

A perspectiva dita progressista e multiperspectivada do uso do objeto tem origem no campo da arte, ao considerar que toda análise do objeto é válida e amparada em um exercício de retórica. O relativismo no campo da interpretação dos objetos de arte se expande para outras áreas, no caso em questão, para a disciplina de História. Entretanto, ao se tratar da análise de evidências históricas, necessita-se de fundamentação teórica e rigor, indo além de um exercício linguístico, com propósito de, ao superar a retórica, se encaminhar para a concepção do real.

A BNCC História sugere um exercício de inquérito/indagação ao objeto, desenvolvido pelos procedimentos de identificação, comparação, contextualização, interpretação e análise, que funcionam como suporte metodológico para o uso de objetos em sala de aula, para, assim, produzir um conhecimento histórico escolar:

A utilização de objetos materiais pode auxiliar o professor e os alunos a colocar em questão o significado das coisas do mundo, estimulando a produção do conhecimento histórico em âmbito escolar. Por meio dessa prática, docentes e discentes poderão desempenhar o papel de agentes do processo de ensino e aprendizagem, assumindo, ambos, uma "atitude historiadora" diante dos conteúdos propostos, no âmbito de um processo adequado ao Ensino Fundamental (BRASIL, 2017a, p. 396).

Na concepção assumida na BNCC, a atitude historiadora encaminha a indagação através da identificação do objeto a ser estudado, da sua comparação com outros objetos de temporalidades e espacialidades diferentes, da sua contextualização em um evento, da sua interpretação para estimular hipóteses, argumentos e comprovações e, por fim, por um resultado final. O processo de indagação ao objeto, no sentido de transformá-lo em fonte histórica, é detalhado através da explicação de como o docente poderá atuar em sala de aula. 
O docente é incumbido, através dos procedimentos de análise de objetos, de desenvolver a atitude histórica junto ao aluno. As explicações históricas, em sala de aula, geralmente reproduzem a explicação dos manuais didáticos. Para produzi-las é necessário rigor teórico e metodológico, em processos mais complexos que os procedimentos expressos na BNCC História.

A interpretação dos documentos e a crítica às fontes não é uma atitude historiadora, mas historiográfica, pois produz um conhecimento histórico. Dessa forma, os procedimentos para a análise das evidências históricas carecem de aprofundamento no campo da problematização dos documentos. Conforme as escolhas curriculares anteriores à BNCC, a análise das evidências históricas deve ir além do inquérito documental por ele mesmo; sugerese como essencial a articulação e a problematização das evidências com conceitos estruturantes das disciplinas: Tempo e Narrativa. Dessa forma, os alunos terão condições de construir interpretações mais complexas e de exercitar a argumentação, como fundamentos para a explicação histórica, para além da retórica.

No decorrer do texto da BNCC, os procedimentos para utilização das evidências históricas são associados aos três conceitos estruturantes do componente curricular de História: Temporalidade, Espacialidade e Diversidade. Porém os conceitos estruturantes não são problematizados em sua complexidade na perspectiva teórica, de modo a serem capazes de promover o desenvolvimento de uma atitude historiográfica, mas sim regidos pelo conceito substantivo de Estado, e com vistas a atender os objetivos práticos e utilitaristas definidos pela proposta curricular. A Área de Ciências Humanas na BNCC justifica a relevância do conceito substantivo ao afirmar que:

As noções de temporalidade, espacialidade e diversidade são abordadas em uma perspectiva mais complexa, que deve levar em conta a perspectiva dos direitos humanos. Essa é uma questão complexa, que envolve a compreensão do conceito de Estado e dos mecanismos institucionais dos quais as diferentes sociedades dispõem para fazer justiça e criar um novo campo republicano de direitos. Portanto, o desafio não está apenas no campo da produção e reprodução de uma memória histórica, mas nos questionamentos com vistas a uma posição ética dos indivíduos em relação ao passado e ao presente. Vários temas decorrem dessa reflexão, tais como a interculturalidade e a valorização das diferenças, em meio a um intenso movimento das populações e dos direitos civis (BRASIL, 2017a, p. 354).

A escolha pelo conceito substantivo não pode ser desvinculada da escolha e organização dos temas e conteúdos em uma perspectiva política e econômica, fundamentada pela abordagem da noção de Estado. Estado é o único conceito substantivo apresentado na área das Ciências Humanas, demarcando, assim, a ausência de outros conceitos substantivos 
relevantes para a compreensão das questões da interculturalidade. A ênfase no conceito em questão denuncia uma forte tendência a um retorno da história de viés político do Estado, uma vez que este conceito substantivo é associado apenas ao contexto republicano de direitos. Fala-se de direitos nos âmbitos constitucionais e humanos, tomando as ideias de respeito e valorização. Vale pensar que, em um contexto específico, é possível que se considere relevante discutir diversidade e diferenças para além do Estado, na perspectiva da construção histórica.

Precede a continuidade dos aspectos do conhecimento histórico a apresentação estrutural dos temas, conteúdos e habilidades expressas no componente curricular de História na BNCC e distribuídas em três colunas, denominadas, respectivamente: Unidades Temáticas; Objetos de Conhecimento; e Habilidades. Tais colunas deverão ser articuladas a partir dos três procedimentos da disciplina de História, que consistem nos seguintes passos: primeiro, identificar os eventos considerados importantes na história do Ocidente, incluindo os continentes africano, europeu e americano, ordenando tais acontecimentos de forma cronológica e localizando-os no espaço geográfico; segundo, desenvolver condições necessárias para que os estudantes selecionem, compreendam e reflitam sobre os significados da produção, circulação e utilização de documentos materiais e imateriais; e, por fim, interpretar diferentes versões de um mesmo fenômeno (BRASIL, 2017a, p. 414).

As unidades temáticas apresentam os temas históricos em ordem cronológica linear e quadripartite, ao dotar a divisão histórica em períodos da Antiguidade Clássica, Medieval, Moderna e Contemporânea, distribuídos linearmente pelos quatro anos finais do Ensino Fundamental, conforme orienta o primeiro procedimento.

O sexto ano, a modelo de currículos anteriores, discute os procedimentos da disciplina de História e adentra os temas relacionados aos conteúdos históricos das primeiras sociedades e da antiguidade clássica, e "avança ao período medieval na Europa e às formas de organização social e cultural em partes da África” (BRASIL, 2017a, p. 415).

A presença dos temas obrigatórios, no que definem as leis 10.639/2003 e 11.645/2008, sobre o ensino da História da África e das culturas afro-brasileira e indígena, são tratados no currículo de História ao longo dos quatro anos. Segundo a BNCC História, a temática "ganha realce não apenas em razão do tema da escravidão, mas especialmente, por se levar em conta a história e os saberes produzidos por essas populações ao longo de sua duração" (BRASIL, 2017a, p. 415). Entretanto, a abordagem é pontual e tem como perspectiva a explicação eurocêntrica de organização do conteúdo e abordagem do conhecimento histórico, ao interpretar as formas de organização social pela lógica capitalista 
europeia, uma vez que os objetos de conhecimento das temáticas africanas e indígenas são abordadas pelo marco temporal do antes e depois da chegada dos europeus em seus territórios. Conforme verificado no objeto do conhecimento do sétimo ano, que propõe o item "Saberes dos povos africanos e pré-colombianos expressos na cultura material e imaterial" (BRASIL, 2007a, p. 421), orienta-se o estudo dos saberes da cultura a partir do marco temporal e referencial da cultura europeia, ao estabelecer a Habilidade EF07HI: "Identificar aspectos e processos específicos das sociedades africanas e americanas antes da chegada dos europeus, com destaque para as formas e o desenvolvimento de saberes e técnicas" (BRASIL, 2007a, p. 421). Destacamos que a habilidade refere-se apenas ao que foi construído como conhecimento anterior à chegada dos europeus, já que no contexto histórico posterior a este fato, o que é posto como relevante no documento curricular é o conhecimento da cultura europeia.

A escolha pelo conceito substantivo Estado, além de exemplificar os procedimentos de utilização das fontes em sala de aula pelo docente, também ganha destaque ao justificar as escolhas do conteúdo histórico manifestado nos objetos de conhecimento. Percebemos a predileção pela História de abordagem política e econômica, ao tratar dos conteúdos, a exemplo da "conquista da América e as formas de organização política dos indígenas e europeus (BRASIL, 2017a, p. 420)", no $7^{\circ}$ ano. A predileção, resultado do campo das escolhas, não invalida a opção feita, mas sinaliza o abandono de abordagens por vezes utilizadas em documentos curriculares anteriores, por exemplo, a História Social.

A escolha realizada resulta na simplificação e no silenciamento de noções tais como diversidade e gênero, que são essenciais para compreender o conjunto de objetos de conhecimento, que, segundo a BNCC, tem como objetivo "aprimorar capacidade de os alunos pensarem diferentes culturas e sociedades, em seus tempos históricos, territórios e paisagens (compreendendo melhor o Brasil, sua diversidade e território)" (BRASIL, 2017a, p. 352).

A simplificação da noção está no teor do conhecimento sobre o passado, que está disponível na temporalidade histórica para apreensão do aprendiz. Nega-se, assim, a abordagem da construção histórica das relações sociais em contextos não apenas políticos, mas culturais e socioeconômicos.

Deter-se na análise das evidências históricas, sem amparo dos conceitos estruturantes da disciplina e sem contextualizar as diferentes dimensões sociais, além da simplificação de noções relevantes, poderá acarretar esquecimentos ou silenciamentos. A noção de gênero, discutida nos estudos da História Nova e aprofundada em correntes teóricas, tais como a História Cultural e em seus desdobramentos, é silenciada e negligenciada no currículo de História. Callegari já alertava sobre a pressão externa sofrida pelos elaboradores 
do currículo, no sentido da proibição do assunto. Historiadores, nas audiências públicas, também exigiam a discussão dos temas que contemplam a diversidade de gênero. Porém, a versão final do documento colabora com o silenciamento, para não falar de omissão. O que mais se aproxima da abordagem de gênero são temáticas atreladas à ação da mulher, em dois momentos: no $6^{\circ}$ ano - objeto de conhecimento: o papel da mulher na Grécia, Roma, e no período medieval, e reforçada na Habilidade EF06HI19: descrever e analisar os diferentes papéis sociais das mulheres no mundo antigo e nas sociedades medievais (p. 418-419); e no $9^{\circ}$ ano - objeto de conhecimento: anarquismo e protagonismo feminino, sem especificar a Habilidade (p. 426-427).

A naturalização do conhecimento histórico, ou seu baixo potencial problematizador, já mencionado na discussão, também é atribuído aos objetivos dos procedimentos de investigação das Ciências Humanas (História e Geografia), que orientam o uso das linguagens e que objetivam "desenvolver a capacidade de observação de diferentes indivíduos, situações e objetos que trazem à tona dinâmicas sociais em razão de sua própria natureza (tecnológica, morfológica, funcional)” (BRASIL, 2017a, p. 353).

A observação precede o agir na BNCC, e, desenvolvida através das habilidades para o uso das linguagens (oral, escrita, cartográfica, estética e técnica), favorece

o diálogo, a comunicação e a socialização dos indivíduos, condição necessária tanto para a resolução de conflitos quanto para um convívio equilibrado entre diferentes povos e culturas. O desafio é grande, exigindo capacidade para responder de maneira crítica, propositiva e ética aos conflitos impostos pela história (BRASIL, 2017a, p. 354).

Sobre a competência de "comunicação", a partir da identificação e observação de diferentes linguagens e fontes, identificamos o caráter limitante da competência ao não possibilitar a "resolução das questões do cotidiano", não possibilitar os estudos da interculturalidade, etc. Para o desenvolvimento do espírito crítico é necessário ter acesso a diferentes perspectivas e concepções, num movimento para além da observação do texto e da linguagem; é necessário o movimento complexo da análise, que requer destaque para o conhecimento do componente curricular.

No contexto, a metodologia de investigação histórica não está a serviço da formação intelectual para a constituição de uma cidadania crítica. O Ensino de História no Ensino Fundamental - anos finais, pretende capacitar o aprendiz para interpretar o mundo, compreender os processos e fenômenos sociais, políticos e culturais - por mais que a ênfase seja os processos políticos -, de modo que o aluno seja capaz de "atuar de forma ética, 
responsável e autônoma diante de fenômenos sociais e naturais” (BRASIL, 2017b, p. 354). Respondendo, assim, às expectativas do modelo de escola neoliberal, deslocando a centralidade do conhecimento disciplinar para o desenvolvimento de competências socioemocionais. Dessa forma, não há um abandono do conhecimento histórico, mas uma mudança de objetivos do ensino e, por consequência, a adequação teórico-metodológica para alcançar os novos objetivos educacionais.

Esses novos objetivos educacionais deverão ser alcançados através do processo de ensino e aprendizagem, que no texto da BNCC História do Ensino Fundamental - anos finais, é desenvolvido por três procedimentos:

Pela identificação dos eventos considerados importantes na história do Ocidente (África, Europa e América, especialmente o Brasil), ordenando-os de forma cronológica e localizando-os no espaço geográfico;

Pelo desenvolvimento das condições necessárias para que os alunos selecionem, compreendam e reflitam sobre os significados da produção, circulação e utilização de documentos (materiais e imateriais), elaborando críticas sobre formas já consolidadas de registro e de memória, por meio de uma ou várias linguagens;

Pelo reconhecimento e pela interpretação de diferentes versões de um mesmo fenômeno, reconhecendo as hipóteses e avaliando argumentos apresentados com vistas ao desenvolvimento de habilidades necessárias para elaboração de proposições próprias (BRASIL, 2017a, p. 414).

Os três procedimentos compõem um instrumento que objetiva articular a tríade: unidades temáticas, objetos de conhecimento e habilidades. O texto da Base justifica e exemplifica o passo a passo dos procedimentos em quatro laudas, de forma didática, para que os professores possam executá-los em sala de aula e os utilizem como parâmetro avaliativo. No decorrer da explicação dos procedimentos, o texto adverte:

O Ensino de História se justifica na relação do presente com o passado, valorizando o tempo vivido pelo estudante e seu protagonismo, para que ele possa participar ativamente da construção de uma sociedade justa, democrática e inclusiva (BRASIL, 2017a, p. 414).

Dessa forma, os procedimentos transcritos acima assumem dupla função, além de proporcionar a articulação dos elementos curriculares - unidades temáticas, objetos de conhecimento e habilidades - também legitimam a permanência da disciplina de História no currículo, nos remetendo ao primeiro aspecto do conhecimento histórico escolar, analisado nesta pesquisa. 


\subsection{TRIANGULAÇÃO DOS DADOS}

Neste item realizamos a triangulação dos dados a partir das mesmas perguntas: qual o conhecimento selecionado como relevante nos documentos curriculares da disciplina de História? Como essa escolha se relaciona com as realizadas em período anterior e com as que valorizam os sujeitos envolvidos com a pesquisa sobre o Ensino de História e com a produção de documentos curriculares? Para isso, definimos os itens que compõem os aspectos do conhecimento histórico curricular, objetivando, dessa forma, responder à pergunta da pesquisa em três contextos documentais diferentes: anterior à BNCC; no processo final de elaboração da BNCC História; e na versão final da Base. Os dados obtidos através da análise das fontes e apresentados nos itens anteriores, possibilitaram a realização da triangulação pelo método comparativo. Dessa forma, a comparação realizou-se a partir dos aspectos do conhecimento histórico e de que forma cada aspecto foi abordado nas propostas curriculares e nos outros documentos analisados.

Identificar o conhecimento histórico escolar é também compreender a legitimação do componente curricular de História nos currículos escolares. Sendo assim, a pergunta "O que ensinar?" atrela-se à outra: por que e para que ensinar? A partir desses questionamentos, identificamos nos documentos curriculares anteriores à BNCC, nas propostas encaminhadas ao CNE e na versão final da BNCC História, as motivações para o retorno e/ou permanência do componente no currículo escolar.

No primeiro contexto da pesquisa, o estudo da História se justifica nos currículos municipais e estaduais, com a finalidade de transformação da realidade do aluno. Entretanto, a formação do aluno para transformação é apresentada em duas perspectivas diferentes: na primeira, a transformação ocorreria através da formação do aluno para o mercado de trabalho, amparada na perspectiva neoliberal; na segunda, a transformação destinaria-se a formar o aluno para o exercício da cidadania crítica e participativa.

O PCN de História ressalta que as questões de identidade têm centralidade no ensino da disciplina, e justifica a sua relevância afirmando que contribui para a compreensão da diversidade nesse campo. A questão das identidades sociais em contexto da diversidade não só legitima a permanência da disciplina no currículo, como orienta as escolhas curriculares do documento. Dessa forma, os documentos curriculares que escolheram como justificativa a formação para cidadania crítica no contexto da diversidade, se aproximam das preocupações assumidas no PCN de História. Entretanto, nem todos os documentos curriculares seguiram de perto as orientações dos PCNs, já que alguns documentos curriculares apresentaram finalidades para a formação do indivíduo em contexto global, 
alinhando-se às exigências do capital econômico neoliberal. Isso explica-se pelo caráter de referencial assumido pelos PCNs, ou seja, não obrigatório como orientação para a produção de propostas curriculares por estados e municípios.

As propostas curriculares encaminhadas ao CNE também destacam a importância da disciplina de História para a formação do aluno, no entanto, os objetivos dessa formação diferem. Os ofícios encaminhados ao CNE enfatizam a necessidade da formação para a cidadania. Um dos proponentes destaca a importância da formação da cidadania alicerçada no discurso de nacionalismo e patriotismo político, noção combatida e ampliada pelas propostas curriculares anteriores à BNCC. Entretanto, um segundo proponente se aproxima das questões de cidadania e diversidade, identificadas nos documentos curriculares da década de 90, ao reconhecer a complexidade educacional necessária para alcançar a formação cidadã plena e ao compreendê-la para além das questões curriculares, incluindo, assim, as esferas sociais, econômicas e políticas.

O Movimento pela Base também sustenta a justificativa para o Ensino de História na busca pela formação do aluno para uma cidadania, mas desenvolve essa ideia em torno das competências socioemocionais. Nessa direção, o objetivo do Ensino de História difere das propostas curriculares anteriores da BNCC e das encaminhadas ao $\mathrm{CNE}$, ao priorizar as habilidades sociais e reduzir a contribuição que a História pode trazer para a formação do pensamento crítico e relacional.

Na versão final da BNCC, o objetivo do Ensino de História é a formação do aluno para compreender o mundo, desenvolver a sua autonomia e a aptidão para nele intervir. Nesse contexto, cabe ao ensino a formação do aprendiz para intervir na sociedade e, para isso, segundo o documento, faz-se necessário o desenvolvimento de habilidades sociais através das competências socioemocionais, destacando, assim, a predileção pela posição assumida diante do CNE pelos representantes do Movimento pela Base.

Apesar da centralidade atribuída à formação socioemocional, o documento da BNCC atribui às Ciências Humanas a formação de uma autonomia intelectual do aluno, para a atuação crítica e a partir de valores democráticos. A relevância da disciplina de História é justificada pela menção ao seu papel na formação dos alunos, a partir das questões do tempo presente. Também se destaca a função atribuída ao componente frente ao desenvolvimento da autonomia de pensamento e o reconhecimento da ação dos indivíduos nos contextos em que vivem, objetivando preservar ou transformar os hábitos e condutas dos aprendizes.

O Ensino de História, na BNCC, assume o objetivo de estimular a percepção da diversidade e o desenvolvimento do pensamento crítico, porém a noção de cidadania não é 
discutida no texto. Conforme o documento, a cidadania é resultado do contato do aluno com a diversidade. Esse aspecto difere das noções apresentadas nos documentos curriculares anteriores à BNCC, em especial o PCN de História, nos quais a formação para cidadania resulta da compreensão da diversidade e dos aprofundamentos das noções identitárias, não o inverso.

Os documentos curriculares anteriores à BNCC fundamentam-se teoricamente no campo das correntes historiográficas. Os que foram analisados nesta pesquisa, nas esferas municipal e estadual, rompem com a corrente historiográfica dita tradicional de base positivista, e adotam diferentes tendências teóricas da historiografia. A corrente historiográfica do Materialismo Histórico, de orientação marxista, era a mais perceptível na documentação curricular produzida no Rio de Janeiro, nas décadas de 80 e 90. Já nas propostas curriculares potiguares, existia a predominância da corrente historiográfica da Nova História, em oposição ao paradigma da História Positivista, dita tradicional. No PCN de História percebem-se as vozes de dois campos historiográficos - discussões realizadas pela Historiografia Social inglesa e influência da Nova História francesa. Além disso, a adoção de mais de uma corrente historiográfica também é percebida nos documentos curriculares paulistas.

Nas propostas encaminhadas ao CNE acerca da BNCC História, apenas a manifestação da ANPUH - PE refere-se à fundamentação teórica no campo das correntes historiográficas. Nela, criticam-se as versões preliminares da Base, ao afirmar que o documento desconsidera as inovações do campo da historiografia, não reconhece as diferentes temporalidades e espacialidades no contexto das diferenças sociais e culturais, e, ainda, que os posicionamentos teóricos adotados colaboram com teorias historiográficas ditas desconexas com o contexto democrático atual, entre elas as teses das três raças e do homem cordial, e o mito da democracia racial.

O texto da BNCC História reconhece a necessidade do conhecimento de referências teóricas para compreender a complexa relação entre as noções temporais de passado/presente e atribuir inteligibilidade aos objetos históricos selecionados e, até certa medida, parece corroborar com a crítica realizada pela ANPUH - PE. Entretanto, a proposta curricular da BNCC História não afirma vinculação a uma determinada corrente historiográfica. O texto discute as noções de tempo/espaço e documentos históricos a partir dos estudos do historiador Ulpiano Bezerra de Menezes (1998), que enfatiza a necessidade do uso de critérios e procedimentos para análise dos objetos históricos. 
Em relação às escolhas teóricas, identificamos a diversidade das correntes historiográficas abordadas nos documentos curriculares anteriores à BNCC e, apesar do PCN de História não ter força de lei - podendo até mesmo ser ignorado -, o documento foi utilizado como referência na elaboração dos documentos curriculares municipais e estaduais. Estes poderiam adotar as referências teóricas sugeridas pelo PCN de História, como, de fato, alguns documentos curriculares adotaram, a partir de várias leituras do PCN.

Entretanto, no contexto da BNCC, o documento curricular é obrigatório e consiste em um primeiro referencial para elaboração das propostas curriculares municipais e estaduais, impactando diretamente na definição do que ensinar. Dessa forma, a ausência de referenciais teóricos mais complexos, a definição dos objetivos do ensino com base na preocupação central com o desenvolvimento de competências socioemocionais, a formação do aluno para atender as necessidades do mercado de trabalho neoliberal e os demais elementos que abordaremos a seguir, não serão opções para compor os documentos curriculares estaduais e municipais, e sim, seleções já realizadas na Base. Esse é o caminho a seguir se estados e municípios estiverem preocupados com a forma como seu trabalho será avaliado. Essa situação se agrava na medida em que as sugestões dos profissionais da área não são acolhidas, conforme verificamos no decorrer deste relatório, como por exemplo, na seleção de conceitos estruturantes da disciplina.

Importa, nesta análise, ressaltar que a seleção de conceitos estruturantes da disciplina de História está associada às escolhas das correntes historiográficas presentes nos documentos curriculares. As noções de tempo e mudança são as mais recorrentes nos documentos curriculares do Rio de Janeiro, anteriores à BNCC. Em um contexto em que era forte a presença do Materialismo Histórico, valorizava-se nas propostas que seus principais conceitos - ligados ao Trabalho, à Cultura e à Sociedade - fossem articulados à realidade concreta do aluno e relacionados ao passado. No documento curricular do Rio Grande do Norte, são destacados os conceitos de Classe Social, Trabalho e Alienação, para além da perspectiva do Materialismo Histórico. As principais noções desenvolvidas no documento curricular do PCN de História são diferenças, semelhanças, transformações e permanências. Segundo o documento curricular, tais noções são essenciais para compreender a diversidade, já que o aluno poderá identificar e distinguir o 'eu' do 'nós', no tempo e nas práticas cotidianas e nas relações sociais em temporalidades e espacialidades iguais e diferentes. No PCN de História, os conceitos estruturantes são definidos para além da compreensão das correntes historiográficas adotadas, mas são relevantes para compreender e explicar a 
construção dos conceitos de Diversidade, Identidade e Cidadania - tríade essencial para os objetivos para o Ensino de História, assumidos no documento curricular.

As propostas encaminhadas ao CNE tratam dos conceitos estruturantes da disciplina de História. A UNDIME propõe a ampliação da noção de sujeito histórico e a inclusão das categorias de família, trabalho e sociedade. Sugere a articulação necessária entre as noções de tempo e espaço, enfatiza a necessidade do estudo de múltiplas temporalidades e da ampliação do recorte espaço-temporal para o século XXI, reforçando, em certa medida, as preocupações conceituais do contexto anterior.

Na mesma perspectiva de ampliação e complexidade dos conceitos estruturantes, segue a sugestão da ANPUH - PE, ao propor que sejam integrados na BNCC os conceitos estruturantes da disciplina de História, tais como Historiografia, Fonte, Memória, Duração, Narrativa e Multicausalidade. Posicionamento semelhante é reforçado pela ANPUH, na audiência em Brasília, ao defender o aprofundamento dos conceitos estruturantes do componente curricular, tais como Acontecimento, Sequência, Duração, Sucessão, Periodização, Fato, Processo, Simultaneidade, Ritmos de Tempo, Medidas de Tempo, Sujeito Histórico, Historicidade, Identidade, Semelhança, Diferença, Contradição, Permanência, Mudança, Evidência, Causalidade, Multicausalidade, Ficção e Narrativa,

$\mathrm{Na}$ versão final da BNCC, o conhecimento disciplinar da área das Ciências Humanas é alicerçado pelos conceitos estruturantes de Tempo, Espaço e Contexto. São conceitos mobilizados para fomentar o desenvolvimento de habilidades sociais (Diálogo, Comunicação e Socialização), consideradas necessárias para a formação do aluno. No texto da BNCC História, a relação tempo/espaço e as relações sociais que a produzem é alcançada pelo processo de análise do uso do objeto ou das questões a serem estudadas. Dessa forma, o objeto torna-se o conceito estruturante da disciplina de História e não se contempla a complexidade dos conceitos estruturantes sugeridos nas audiências públicas de elaboração da BNCC História; também se opera um distanciamento da complexidade conceitual abordada nos documentos curriculares anteriores à BNCC, já que tais documentos propunham a construção dos conceitos a partir do rigor da investigação histórica, associada às correntes historiográficas.

Prosseguindo com a triangulação dos dados, verificamos que nos documentos curriculares anteriores à BNCC, as noções de tempo e espaço são consideradas essenciais para a compreensão da própria concepção do componente de História, além de definirem a organização do conhecimento e a escolha dos temas e conteúdos historiográficos. 
Os documentos curriculares do Rio de Janeiro, produzidos na década de 90, embasaram-se na perspectiva historiográfica do Materialismo Histórico, que orientou as decisões curriculares do componente de História, entre estas, a escolha e organização dos conteúdos históricos. Os conceitos do Materialismo Histórico (Trabalho, Cultura e Sociedade) seriam pré-condição para o aluno prosseguir os estudos dos conteúdos temáticos de História, associados aos casos concretos oriundos do cotidiano. O currículo do Rio Grande do Norte identifica que, para o ensino do primeiro grau (atual Ensino Fundamental), foi adotada a opção metodológica pela organização dos conteúdos em Eixos Temáticos, porém, permanece o recurso de organizar o conteúdo histórico em evolução linear e cronológica do tempo e em quatro períodos - História Antiga, História Medieval, História Moderna e História Contemporânea -, tradicional temporalidade histórica quadripartite.

O PCN de História representou um processo inovador de prescrição para o Ensino de História, ao organizar os conteúdos em torno de Eixos Temáticos. Isso exigiu um debate sobre as noções de tempo histórico, questionando as concepções de linearidade, progresso, decadência e evolução presentes nos currículos anteriores, pois, diferentemente do currículo potiguar, o PCN de História, ao adotar esse modo de organização, rompe, de fato, com a perspectiva de evolução linear e cronológica.

Apesar do PCN de História ter sido uma forte referência na elaboração dos currículos municipais e estaduais, estes não incorporaram a organização do conhecimento histórico por Eixos Temáticos. Diante da autonomia na elaboração dos currículos escolares em relação ao PCN de História, predominou a estruturação organizacional do conteúdo histórico de ordem temporal - cronológica, evolucionista e linear - e quadripartite.

Em relação às noções de tempo e espaço na escolha e organização do conhecimento histórico no currículo, a ANPUH - SC critica a permanência do "tempo" linear e progressivo, marcada pela forte permanência da História quadripartite, eurocêntrica e cronológica. Identifica a presença dos conteúdos historiográficos relacionados à História africana, afro-brasileira, indígena e às questões de gênero, porém salienta que os conteúdos históricos carecem de aprofundamento e ampliação nas abordagens. A ANPUH - SP avança na discussão, corroborando com a ANPUH - SC, ao apontar a ausência das discussões sobre o conhecimento histórico produzido no tempo presente e da relação do passado com outras temporalidades, não se atribuindo, assim, sentido espacial e temporal para o Ensino de História. Sugere que a BNCC rompa com a abordagem eurocêntrica, adote abordagens temporais para além do tempo cronológico e linear e que, por fim, em sua seleção, seja ampliado o recorte temporal, contemplando as questões da história do tempo presente. 
Em relação à escolha do conteúdo histórico, a temática indígena foi tratada nas duas primeiras audiências públicas. Na primeira, sugeriu-se que a versão final da BNCC superasse a abordagem homogeneizadora das populações indígenas identificada na versão preliminar. Segundo o proponente, o documento nega a diversidade cultural representada pelas diferentes etnias e a abordagem histórica centrada apenas na temporalidade do passado negligencia a atuação contemporânea indígena na História do tempo presente.

$\mathrm{Na}$ segunda audiência, retoma-se a problemática do eurocentrismo - ênfase à história ocidental, negligenciando as experiências das populações indígenas, africanas e latino-americanas; a adoção do processo histórico cronológico - com sua negligência em relação à complexidade temporal da história e restrição ao estudo do passado pelo passado, negando a história do tempo presente. Propõe-se, em seu lugar, que seja cumprido o que estabelecem a lei $n^{\circ} 10.639 / 2003$ e sua correlata lei $n^{\circ} 11.645 / 2008$, que determinam a obrigatoriedade do Ensino de História e Cultura Africana, Afro-Brasileira e Indígena.

Por fim, no Parecer final produzido pelo CNE, o conselheiro Callegari afirma que encaminhou propostas para o componente de História que não foram atendidas. Em tom de desabafo, aponta os problemas da concepção histórica factual, linear, cronológica e descontextualizada e declara ser contra a exclusão das questões de gênero, afirmando que o MEC e a maioria dos membros do CNE cederam às pressões externas dos que se posicionaram contra a abordagem dessas questões na BNCC.

O documento final da Base afirma a presença dos temas obrigatórios, no que definem as leis 10.639/2003 e 11.645/2008 sobre o Ensino de História da África e das culturas afro-brasileira e indígena, que é tratado de forma pontual e eurocêntrica no currículo de História ao longo dos quatro anos. Como previsto pelo conselheiro Callegari, a noção de gênero não é abordada no currículo de História. As escolhas realizadas na BNCC contrariam os historiadores, que nas audiências públicas exigiam a discussão e aprofundamento dos temas que contemplam a diversidade e a pluralidade cultural, bem como a abordagem das questões de gênero.

Percebemos o impasse no desenvolvimento e aprofundamento em relação aos temas pertinentes à diversidade nos documentos curriculares. Esse impasse já era percebido desde a década de 80 e 90 (GALIAN, 2014). Assim, embora os PCNs avançassem com a introdução dos aspectos alusivos às relações étnico-raciais e de orientação sexual, as propostas curriculares de estados e municípios avançaram de forma tímida nesse sentido. Não se reconhece "uma abordagem crítica desses aspectos nos documentos que orientam o trabalho da escola, para além das simples afirmações teóricas, avançando nas indicações de 
formas de tratamento dessas temáticas" (GALIAN, 2014, p. 652). Na BNCC, optou-se por manter essas questões no campo da retórica, da afirmação genérica de princípios, pois o documento reconhece a exigência da lei em relação aos temas, mas a proposta apresentada chega a ser evasiva - ao tratar das questões étnico-raciais sem amplitude e aprofundamento e omissa - ao negligenciar as questões complexas de gênero. Em um contexto comparativo, a escolha apresentada pela BNCC tende a agravar o silêncio nas propostas curriculares estaduais e municipais acerca dos temas ligados às diversidades, pois trata-se de um referencial obrigatório para elaboração dos currículos escolares.

No documento da BNCC História, as unidades temáticas apresentam objetos do conhecimento histórico em ordem cronológica linear e quadripartite ao adotar a divisão histórica em períodos da Antiguidade Clássica, Medieval, Moderna e Contemporânea, distribuídos linearmente pelos quatro anos finais do Ensino Fundamental.

A ordem de abordagem dos períodos não é vista como uma problemática para a BNCC História, parece ser apenas uma escolha metodológica de organização de conteúdos, sem que se discutam as implicações disso para o estabelecimento de relações com o conhecimento histórico, contrariando, assim, as contribuições enviadas para o processo de elaboração da Base - os quais atribuem importância, não apenas ao modelo de organização do conteúdo, como também ao próprio conteúdo historiográfico. Na contramão das proposições encaminhadas ao CNE, a BNCC História sustenta a ideia de que é possível formar o aluno seguindo o desenvolvimento das competências específicas do componente, em articulação com as competências gerais da BNCC e com as competências específicas da área de Ciências Humanas, minimizando, assim, a relevância da discussão sobre a importância do conteúdo historiográfico.

Diante da situação, a BNCC História afirma que o modelo de agrupamento dos temas sugerido não precisa ser obrigatório, indicando a possibilidade de outras formas de organização do conteúdo. Entretanto, o documento da Base é prescritivo: a orientação expressa contradiz a obrigatoriedade curricular traduzida em forma de lei e não de referência, a exemplo do PCN.

A depender da concepção de currículo adotada nos documentos curriculares, são incorporadas de formas distintas as questões do conhecimento histórico a ser ensinado, os aspectos metodológicos, avaliativos e de aprendizagem da disciplina escolar.

Os aspectos metodológicos para o Ensino de História presentes nos documentos curriculares anteriores à BNCC, guardam correspondência com as preocupações das correntes 
historiográficas da História Social Inglesa e da Nova História, principalmente no que concerne à problematização da evidência para a produção da narrativa histórica.

Nas propostas encaminhadas durante o processo de elaboração da BNCC, não há uma escolha específica por uma abordagem teórica, mas os proponentes salientam a necessidade do rigor das teorias para o compromisso com os métodos da investigação histórica. A UNDIME manifesta preocupações em relação aos métodos investigativos da disciplina, solicitando, por exemplo, que a questão da investigação histórica ultrapasse a metodologia do uso das fontes, para compreensão da complexidade do processo, através da investigação da ciência ensinada.

$\mathrm{O}$ rigor dos métodos de investigação é colocado em pauta pela ANPUH - PE, cujo representante propõe que sejam afirmados os pressupostos metodológicos da escrita da História, para promover a compreensão do saber escolar como produção científica e social, e que os acontecimentos das diversas temporalidades sejam transformados em problemas históricos a serem estudados e investigados.

Na versão final da BNCC História, a concepção assumida para a investigação histórica é denominada de atitude historiadora. A atitude consiste em indagações ao objeto histórico, através da identificação do objeto a ser estudado, da sua comparação com outros objetos de temporalidades e espacialidades diferentes, da sua contextualização em um evento, da sua interpretação para estimular hipóteses, argumentos e comprovações e, por fim, de um resultado final. O processo de indagação ao objeto, no sentido de transformá-lo em documento histórico, é detalhado através de explicação de como o docente poderá agir em sala de aula. A atitude historiadora resulta na construção das explicações históricas em um resultado final, no âmbito das melhores ou piores explicações históricas. Enfatizamos que para produzir as condições para que a atitude histórica seja desenvolvida junto aos estudantes, é necessário rigor teórico e metodológico, uma vez que isso envolve processos mais complexos que os procedimentos expressos na BNCC História.

Verificamos que os aspectos metodológicos da investigação histórica são discutidos nos três contextos da pesquisa, apesar de serem identificados pontos de convergência e divergência no seu tratamento. Nos dois primeiros contextos, salienta-se a necessidade do uso da investigação histórica a partir do rigor teórico-metodológico das fontes, com objetivo de proporcionar o entendimento complexo dos conceitos da natureza histórica (Causa, Mudança, Evidência e Interpretação). No terceiro contexto, apresentado no texto final da BNCC História, define-se um caminho para a investigação histórica, através do roteiro de análise do objeto. Ignora-se, assim, a complexidade do processo de investigação histórica 
expressa nos documentos curriculares anteriores e, também, não se acolhem as sugestões encaminhadas ao CNE em relação ao rigor teórico-metodológico da disciplina de História.

Os aspectos avaliativos e de aprendizagem da disciplina escolar são abordados no primeiro contexto da pesquisa. Os documentos curriculares produzidos anteriormente à BNCC, em especial o PCN História, discutem a relação entre o conhecimento histórico e os processos de avaliação e aprendizagem. O PCN História contempla aspectos da aprendizagem e da avaliação do conhecimento histórico. A referência à aprendizagem é destacada pela adoção dos novos objetivos, para a valorização da ação do aluno no processo de aprendizagem. Esse caminho se sustenta nos objetivos já apresentados em outros documentos curriculares, tais como identificar, descrever, caracterizar, ordenar, etc. No campo avaliativo, o documento sugere critérios e modos de avaliação e propõe encaminhamentos didáticos, reconhecendo o estudo do meio como uma interessante metodologia de pesquisa e de organização de novos conhecimentos.

No segundo contexto da pesquisa, a relação entre o conhecimento histórico e os processos de avaliação e aprendizagem não é contemplada nos comentários encaminhados ao CNE. Não é possível encontrar justificativa para a ausência dessa discussão na documentação analisada, porém acreditamos que o curto tempo para debate nas audiências públicas e as várias questões contempladas nos demais aspectos do conhecimento histórico tenham colocado as questões de avaliação e aprendizagem à margem do debate.

No texto da BNCC História, diz-se que no processo de ensino e aprendizagem objetiva-se articular a tríade curricular: unidades temáticas, objetivos de conhecimento e habilidades. Para isso, estabelecem-se três procedimentos que consistem em: identificar os eventos considerados importantes; analisar os documentos históricos; e interpretar diferentes versões de um mesmo acontecimento. Acredita-se, assim, que a consecução desses procedimentos garanta o cumprimento dos objetivos do ensino do componente curricular. Neste contexto, os procedimentos a serem executados pelos docentes em sala de aula servem, ao mesmo tempo, de instrumento para a avaliação da aprendizagem. Os procedimentos expressos na BNCC História diferenciam-se dos aspectos metodológicos e avaliativos valorizados no PCN de História, já que o último se ampara no rigor teórico-metodológico das teorias historiográficas, e sugere caminhos metodológicos mais complexos e que podem ser realizados, ou não, a depender das escolhas curriculares das redes e dos professores. A BNCC História define, explica e exemplifica como realizar os procedimentos, e dita o passo a passo a ser seguido para alcançar os objetivos de aprendizagem, reforçando, assim, a essência obrigatória assumida para o documento curricular. 
A análise da produção curricular do Ensino de História nos três contextos da pesquisa - nos documentos curriculares anteriores à $\mathrm{BNCC}$, nos encaminhamentos ao $\mathrm{CNE} \mathrm{e}$ na versão final da BNCC -, buscou compreender os diversos aspectos do conhecimento histórico escolar presentes no debate sobre a seleção curricular para o componente de História. Percebemos, na triangulação dos dados, indicações de processos de continuidades e rupturas em relação à essa definição do conhecimento histórico, considerado relevante para compor o currículo escolar, o que retomamos e aprofundamos nas considerações finais. 


\section{CONSIDERAÇÕES FINAIS}

Toda pesquisa inicia-se com uma pergunta provocativa. Ela é o que nos move em busca da construção do objeto e se desdobra em um caminho de tantas outras perguntas a se investigar, em torno do mesmo objeto. Portanto, aqui estamos, por ora, para findar a pesquisa e demonstrar que as inquietações iniciais foram contempladas durante o processo investigativo, pois conseguimos identificar: as posições ressaltadas na produção acadêmica sobre os conhecimentos históricos assumidos como relevantes nos currículos de História, nos PCNs e em documentos nele embasados; as perspectivas dos profissionais da Educação e dos historiadores em relação aos conhecimentos históricos que deveriam ser abordados na escola, no processo de produção da BNCC; e, por fim, os conhecimentos históricos que foram definidos como essenciais no documento da $\mathrm{BNCC}$, conferindo destaque às vozes que foram ouvidas e silenciadas na sua produção.

Identificamos o conhecimento histórico presente na BNCC História do Ensino Fundamental - anos finais, através da abordagem da História Social do currículo. Esse movimento contemplou a identificação do conhecimento curricular de história, selecionado e organizado em documentos curriculares produzidos antes da BNCC, e a análise das sugestões e encaminhamentos sobre o componente de História enviados ao CNE. Por meio desse caminho, buscamos lançar luz às disputas no campo curricular de História, de modo a identificar a relação entre as permanências e rupturas curriculares e as vozes silenciadas e expressas na versão final da BNCC.

O primeiro foco de atenção para a identificação de permanências e rupturas entre os três contextos analisados, trata da preocupação com a fundamentação teórica no campo das correntes historiográficas, expressa nos documentos curriculares. Embora a preocupação em embasar o conhecimento histórico em referenciais teóricos perpasse os três contextos da pesquisa, constituindo uma permanência em algum grau, a escolha e a especificação das correntes são as variantes do processo e o ponto de ruptura entre as propostas curriculares.

Identificamos que as propostas curriculares produzidas antes da BNCC, tendo o PCN como um referencial não obrigatório para os estados e municípios, fundamentaram-se em dois movimentos historiográficos. O primeiro emerge da crítica à historiografia tradicional dita positivista, e o segundo resulta da incorporação dos novos campos historiográficos, entre eles as teorias marxistas, neomarxistas e a Nova História. Nesse sentido, as escolhas teóricas foram explicitadas nos documentos curriculares e refletidas diretamente em outros aspectos, a exemplificar, no rigor atribuído à investigação histórica para a compreensão dos conceitos 
estruturantes da disciplina. Nesse contexto, reconheceu-se uma tendência a se contemplar com mais ênfase os conceitos de Trabalho, Sociedade e Cultura.

Já no contexto de elaboração da BNCC - acessado pela análise dos documentos encaminhados ao CNE, expresso no documento preliminar da $3^{\text {a }}$ versão e nas falas apresentadas nas audiências públicas - não se identificou a predileção por uma fundamentação teórica no campo das correntes historiográficas. Os proponentes, ao criticar a versão preliminar da Base, apontavam a importância do rigor teórico e a necessidade de acompanhar as inovações historiográficas, sugerindo que a versão final da BNCC História expressasse o compromisso teórico e conceitual estruturante da disciplina.

Em sintonia com isso, a versão final da BNCC declara a importância do conhecimento de referenciais teóricos, entretanto, não faz alusão às inovações do campo historiográfico, conforme sugerido nos materiais encaminhados ao CNE, mas opta por priorizar três conceitos estruturantes: Objeto, Tempo e Contexto. Assim, ampara-se nos estudos da cultura material, em particular pela pesquisa do professor Ulpiano B. de Menezes. Essa escolha curricular parece limitante ao não aderir às sugestões dos historiadores, que solicitaram que o documento final acolhesse e aprofundasse o processo de investigação histórica e, consequentemente, a construção histórica dos conceitos estruturantes de diferentes correntes teóricas, tais como: História, Fonte, Historiografia, Memória, Acontecimento, Sequência, Duração, Sucessão, Periodização, Fato, Processo, Simultaneidade, Ritmos de Tempo, Medidas de Tempo, Sujeito Histórico, Historicidade, Identidade, Semelhança, Diferença, Contradição, Permanência, Mudança, Evidência, Causalidade, Multicausalidade, Ficção, Narrativa.

A opção pelo conceito estruturante objeto, eleito pela BNCC História, sinaliza a importância dada ao processo de transformação do objeto em documento histórico. O método para esse processo se apoia exclusivamente no inquérito ao objeto, utilizando-se de um aspecto do processo metodológico da investigação histórica - a pergunta investigativa. $\mathrm{O}$ aspecto metodológico da investigação histórica também permeia as preocupações curriculares nos três contextos da pesquisa, constituindo o segundo ponto de permanência reconhecido na análise desenvolvida nesta pesquisa e, em certa medida, de ruptura, já que os métodos de investigação histórica nos contextos diferentes apresentam especificidades em seu grau de simplificação ou aprofundamento, constituindo mudanças dentro da permanência.

As propostas curriculares anteriores à BNCC, seja nas esferas municipais ou estaduais, e também no nível federal, no PCN de História, recorriam aos procedimentos investigativos da História com objetivos diversos, tais como proporcionar o entendimento 
complexo dos conceitos da natureza histórica (Temporalidades, Fonte Histórica, Fato Histórico, agregados a outros como cotidiano e dialogicidade), construir um conhecimento escolar a partir da ciência ensinada ou mesmo como meio para a utilização das fontes históricas em sala de aula. Porém, nesse período a investigação histórica tendia a ser amparada pelo rigor das teorias historiográficas e a objetivar a compreensão dos conceitos estruturantes da disciplina de História.

Em um contexto de comparação, a metodologia valorizada e prescrita na BNCC é limitante, ao centrar apenas na análise do objeto por ele mesmo, não favorecendo a compreensão e construção dos conceitos de natureza histórica. A escolha metodológica investigativa já era criticada mesmo antes da publicação da versão final do documento, quando a UNDIME e a ANPUH encaminharam sugestões de aprofundamentos das questões investigativas da disciplina de História, propondo que a questão da investigação histórica ultrapassasse a metodologia do uso das fontes e promovesse a compreensão da complexidade do processo histórico. Entretanto, verificamos que as proposições não foram acolhidas nessa versão final.

O terceiro foco de permanência e ruptura considerado na análise refere-se à organização dos conteúdos históricos em relação aos recortes temporais e espaciais como eixos para a escolha e a organização do conteúdo histórico. Identificamos no primeiro contexto da pesquisa, o não abandono da História balizada pelo tempo linear, cronológico e quadripartite, apesar de se identificar a organização de algumas propostas curriculares por Eixos Temáticos ou Eixos Conceituais - vale recordar que nesse período o documento federal, PCN, não tinha caráter obrigatório, podendo ou não ser tomado como referência para esses documentos e em diferentes graus de afiliação, em propostas curriculares estaduais e municipais.

Os historiadores representantes da ANPUH que participaram das audiências públicas quando da elaboração da BNCC, manifestaram o descontentamento pela permanência do modelo de organização do currículo de História. O desejo de ruptura era unívoco entre os especialistas, que sugeriram, ainda, o rompimento com a abordagem eurocêntrica, a utilização de abordagens temporais para além do tempo cronológico e linear e, por fim, a ampliação do recorte temporal, contemplando as questões da história do tempo presente.

Callegari, conselheiro do CNE, também pontuou insatisfação pela escolha da organização do conhecimento histórico na BNCC História, caracterizando-a como factual, linear, cronológica, descontextualizada e alienante. Entretanto, em direção oposta, a UNDIME 
defendeu a organização curricular proposta pela BNCC e argumentou que o estudo de temas da História do Brasil, por si só, promoveria o rompimento com a perspectiva eurocentrista. Porém, para os historiadores representantes da ANPUH, o simples fato de tratar de temas da História do Brasil e da História africana, afro-brasileira e indígena não garante uma abordagem não eurocentrista da temática.

Para os profissionais da área, reunidos na ANPUH, as temáticas citadas acima são contempladas no documento da BNCC de forma pontual e homogeneizada, já que não há a integração entre as temáticas no decorrer do processo histórico, nem a identificação e abordagem de especificidades de diferentes etnias.

Nas audiências públicas realizadas em Manaus e Pernambuco, os historiadores solicitaram alterações; contudo as proposições para o rompimento com a organização e aprofundamento dos conteúdos não foram aceitas, a julgar pelo que compõe a versão final da BNCC. No mesmo contexto, e na contramão da proposta dos historiadores, o Movimento pela Base sugeriu a redução das habilidades ligadas ao desenvolvimento da criticidade e propôs a simplificação da noção temporal.

A versão final da BNCC História expressa a organização linear, cronológica e quadripartite, contrariando a sugestão dos historiadores e aborda as temáticas ligadas às culturas africanas, afro-brasileiras e indígenas na lógica homogeneizadora, sem favorecer o desenvolvimento da criticidade, que demandaria o aprofundamento de estudos e análises, reafirmando as sugestões encaminhadas pelo Movimento pela Base.

Ainda no âmbito das questões relacionadas aos temas e conteúdos históricos, foram várias as manifestações sobre a inclusão das questões de gênero. Pedidos da ANPEd, da ANPUH (suas várias seções) e do conselheiro Callegari também não foram atendidos. A UNDIME também se manifestou sobre a inclusão de temas ligados aos movimentos sociais e à ampliação das noções de sujeito - inclui-se aí a questão de gênero. Entretanto, como já sinalizado por Callegari, forças externas ao CNE impediram a inclusão dessa temática.

A negação da inclusão das temáticas de gênero e o não aprofundamento das questões ligadas às culturas africanas, afro-brasileiras e indígenas, reforçam a desvalorização e o esvaziamento das discussões sobre identidade e diversidade na BNCC História. Isso marca o quarto foco de análise de permanências e rupturas entre os contextos considerados na pesquisa, já que as discussões citadas acima, ao inverso do que restou na versão final da BNCC, tinham alcançado algum avanço - ainda de forma tímida - nos documentos curriculares da década de 90 , sob as orientações do PCN para o tratamento da pluralidade 
cultural em temas transversais, amparando-se nas inovações historiográficas e no que dispõem as leis $10.603 / 2003$ e $11.465 / 2008$.

O quinto foco de análise de permanência e ruptura incide sobre a definição dos objetivos para o Ensino de História no Ensino Fundamental, essencialmente nas diferentes contribuições esperadas do componente para a formação do aluno. Nos documentos curriculares anteriores à BNCC, a formação do aluno para a cidadania era a questão central que justificava o Ensino de História nos currículos escolares.

Nas contribuições para elaboração da versão final da BNCC, despontaram tanto as menções ao conceito de cidadania atrelado à formação do aluno e entendido a partir da complexidade e amplitude de sua definição, quanto, no outro extremo, a retomada da noção de formação cidadã, amparado em modelos das décadas de 70.

O Movimento pela Base também sugeriu a formação do aluno para uma certa versão de cidadania, fortemente ligada ao desenvolvimento de suas competências socioemocionais. Essa posição demandava que a BNCC ampliasse as habilidades relacionadas ao autoconhecimento e lançasse mão da História para promover a compreensão, expressão e controle das emoções. Isso se daria pela negligência, em certa medida, da importância da compreensão dos conceitos de natureza histórica e pela ênfase no desenvolvimento das habilidades socioemocionais, tais como Empatia e Responsabilidade. A sugestão, portanto, era de que o Ensino de História, através da centralidade assumida para as habilidades citadas, fomentasse a relação e a colaboração entre os alunos e a discussão de temas que sustentassem o desenvolvimento de projetos de intervenção social.

Decerto, na versão final da BNCC História, permaneceu o objetivo de formar o aluno para uma específica versão da cidadania, no contexto das exigências do neoliberalismo, aparentemente bastante ligada à posição assumida pelo Movimento pela Base. Coerentemente com essa escolha, o conceito de cidadania não foi ampliado e considerado em sua complexidade, nem restrito às questões nacionalistas de cunho patriótico.

Para a BNCC, a formação do aprendiz está associada ao desenvolvimento de habilidades sociais e, para esse fim, definem-se competências socioemocionais necessárias para os alunos, o que incorpora, mais uma vez, a posição afirmada pelo Movimento pela Base. Percebemos que nas propostas curriculares anteriores à BNCC, havia uma sinalização para a formação do aluno para atender as exigências da economia neoliberal, mas não se falava em habilidades de comportamento social. Isso, se não pode ser considerado uma ruptura, certamente constitui um aprofundamento de preocupações já presentes no cenário educacional brasileiro, desde antes da reforma à qual se vincula a BNCC. 
O contexto atual do neoliberalismo projeta a escola para formar assalariados adaptáveis às constantes transformações e instabilidades econômicas, que exigem que os sujeitos sejam capazes de resolver os problemas do cotidiano, em grande parte frutos desse mesmo contexto, e de se adaptarem obedientemente ao que lhes for demandado. Não cabe nessa perspectiva a ideia de aprofundamento de um repertório cultural para a compreensão e a participação críticas no mundo. Alcançar esse nível de adaptabilidade e resiliência supõe que o aprendiz desenvolva o controle das suas emoções, para agir de forma alinhada aos interesses de cunho neoliberal. Dessa forma, a BNCC, no que tange ao componente de História, opera um movimento no sentido de atender aos interesses do mercado econômico, quando reduz a expectativa de desenvolvimento do pensamento relacional dos estudantes e limita a relação com o conhecimento às necessidades mais imediatas do cotidiano. Não se está afirmando que esse processo é instaurado pela BNCC; no contexto anterior à BNCC, ele já se expressava em diferentes graus. Todavia, no atual cenário, evidencia-se a crescente força dos setores empresariais para intervir diretamente nas políticas educacionais, a partir da ação de seus apoiadores, especialmente representados pelo Movimento Pela Base.

As contribuições encaminhadas pelos historiadores representantes da ANPUH, pelos profissionais que elaboraram as proposições junto à UNDIME, pela ANPEd e pelos demais sujeitos cujas falas foram destacadas nesta pesquisa não foram acolhidas. Consequentemente, essas não estão expressas na versão final da BNCC, por não se alinharem com as questões de cunho político-econômico e, por vezes, por ferir os interesses de grupos conservadores, igualmente fortalecidos no atual cenário político brasileiro. Entretanto, compreendemos que, se o processo de elaboração do documento é afirmado como democrático, o primeiro passo seria ouvir as diferentes vozes - o que o MEC insiste que foi feito; mas isto não basta; como segundo passo seria preciso debater e realizar escolhas, realmente considerando todos os olhares sobre o tema. Para o MEC, porém, o primeiro passo parece ser considerado suficiente para declarar que o processo foi democrático.

As únicas propostas referentes ao componente curricular de História que foram encaminhadas ao CNE e atendidas no texto final da base, foram as realizadas pelo Movimento pela Base. Referimo-nos às seguintes propostas: redução da criticidade histórica, acréscimo de competências socioemocionais e abordagem de temas históricos na perspectiva homogeneizadora.

As vozes silenciadas são as vozes que criticaram a BNCC e o conhecimento histórico escolar nela selecionado. Vozes que sugeriram aprofundamentos, ampliações e inclusões de temas, métodos e abordagens necessárias para a cognição histórica mais 
complexa e problematizadora não foram expressas na versão final do documento, embora estivessem em sintonia com os campos da História e do Ensino de História.

Ao silenciar essas posições, o MEC alinha-se a determinados interesses econômicos e políticos que estão em jogo. A partir desse posicionamento, identificamos os deslocamentos do conhecimento da disciplina de História no currículo escolar: o primeiro, dá ênfase ao conhecimento disciplinar para as competências socioemocionais - expressas nas habilidades, atitudes e valores afirmados na BNCC; o segundo, do processo de ensino para o de aprendizagem - um viés utilitarista e prático, voltado a adequar o aprendiz ao mercado de trabalho, sem questionar o que se aprende e para que, mas objetivando que o aluno esteja sempre disposto a aprender e emocionalmente preparado para resolver ou/e se adequar aos problemas econômicos e sociais. O campo desse deslocamento é árido e marcado pelos conflitos por ocasião da elaboração da BNCC, manifestados nas audiências públicas e nos documentos escritos e encaminhados ao CNE.

Dessa forma, concluímos que as vozes silenciadas divergem das escolhas curriculares e dos movimentos de deslocamento antes referidos, alinhados ao contexto político-econômico. As vozes efetivamente ouvidas, coerentes com esses deslocamentos, são legitimadas e alinhadas aos posicionamentos de entidades internacionais do capital neoliberal. Sendo assim, os deslocamentos são resultado de embates no campo mais amplo de conflitos em torno das questões curriculares, no que se refere ao conhecimento escolhido para ser ensinado na escola.

A pesquisa apresentou limitações referentes às perguntas que não foram apontadas no texto, mas que surgiram com o desenvolvimento do trabalho e que, devido a não localização de documentos, não pudemos responder. Por exemplo, a identificação dos sujeitos responsáveis pelas escolhas apresentadas na versão final da BNCC História e os lugares sociais ocupados por estes.

As discussões sobre gênero nas propostas curriculares também apresentaram limitações, ao não contemplar as discussões propostas pelos Movimentos Escola Sem Partido (MESP), fundado em 2004, e o Educação Democrática, um desdobramento do "Professores contra o Escola sem Partido", fundado em 2015. Não foi possível compreender o alcance desse debate na elaboração da BNCC História, pois não há registro documental enviado ao CNE, nem participação das entidades citadas nas audiências públicas. Dessa forma, a ausência se justifica pelo recorte documental adotado na pesquisa.

Para além das limitações, a pesquisa contribui para ampliar os elementos que embasam as reflexões sobre o Conhecimento Histórico Escolar nos debates da História Social 
do Currículo, uma vez que analisamos a seleção do conhecimento histórico curricular como um processo de construção histórico-social, que se desenvolve nas ações dos sujeitos em seus contextos, frente a influências múltiplas, portadoras de diferentes potenciais para se fazer valer.

A pesquisa contribui também com uma forma de analisar o conhecimento histórico escolar, conferindo atenção a aspectos diversos na leitura de fontes distintas, como a justificativa para a presença do componente no currículo escolar; a fundamentação teórica escolhida para os documentos no campo das correntes historiográficas; os conceitos estruturantes da disciplina; a organização do conhecimento; os temas e conteúdos historiográficos; e os processos metodológicos da investigação histórica.

A pesquisa, além disso, identificou e situou o conhecimento histórico escolar em contextos de deslocamentos - da centralidade do conhecimento disciplinar para as competências socioemocionais, e do ensino para a aprendizagem -, proporcionado, assim, elementos para a leitura crítica da versão final da BNCC História, que permitem discutir possíveis avanços e limitações do documento curricular - já que as propostas curriculares, compreendidas como uma dimensão do currículo em processo, não o definem na totalidade e nunca podem ser tomadas como um cânone fixo e inquestionável.

Dessa forma, a pesquisa que agora se encerra, tem potencial para contribuir com estudos futuros, relacionados ao processo de elaboração dos currículos escolares em nível federal, estadual e/ou municipal, apontando um caminho possível para o debate sobre o conhecimento histórico escolar selecionado nos documentos curriculares em diferentes contextos e temporalidades. 


\section{REFERÊNCIAS}

ABUD, K. M. Processos de construção do saber histórico escolar. Revista História \& Ensino, 11, p. 25- 34, 2005. Disponível em:

http://www.uel.br/revistas/uel/index.php/histensino/article/view/11834. Acesso em: 05 de setembro de 2019.

ALMEIDA NETO, A. S. de e CIAMPI, H. A história a ser ensinada em São Paulo. Educação em Revista; 31(1), 195-221, 2015. Disponível em: http://www.scielo.br/pdf/edur/v31n1/01024698-edur-31-01-00195.pdf. Acesso em: 19 de janeiro de 2018.

ANPEd. Ofício 220 - 15 de janeiro de 2016, Rio de Janeiro, 2016. Disponível em: http://portal.mec.gov.br/component/content/article?id=57031. Acesso em: $04 \mathrm{de}$ abril de 2018.

ANPEd. Ofício 211 - 11 de setembro de 2017, Rio de Janeiro, 2017. Disponível em: http://portal.mec.gov.br/component/content/article?id=57031. Acesso em: 04 de abril de 2018.

ANPUH/BRASIL. Audiência Pública e a $3 a$. versão da BNCC: o lugar da ANPUH no debate. GT de Ensino de História e Educação pela Associação Nacional de História/ANPUH, 18 de setembro de 2017a. Disponível em: https://anpuh.org.br/index.php/2015-01-20-00-0155/noticias 2/noticias-destaque/item/4343-audiencia-publica-e-a-3-versao-da-bncc-o-lugar-daanpuh-no-debate. Acesso em: 17 de abril de 2018.

ANPUH/BRASIL. Falas direcionadas ao componente curricular de História. $5^{\text {a }}$. Audiência Pública- CNE em Brasília (vídeo), 2017b. Disponível em: http://portal.mec.gov.br/component/content/article?id=57031. Acesso em: $17 \mathrm{de}$ abril de 2018.

ANPUH/PE. Falas direcionadas ao componente curricular de História. $2^{\mathrm{a}}$. Audiência Pública- CNE em Recife (vídeo), 2017. Disponível em:

http://portal.mec.gov.br/component/content/article?id=57031. Acesso em: $17 \mathrm{de}$ abril de 2018.

ANPUH/SC. 059 Ofício - Parecer da ANPUH-SC sobre a terceira versão da Base Nacional Comum Curricular de História. $3^{\mathrm{a}}$. Audiência Pública- CNE em Florianópolis, 2017a. Disponível em: http://portal.mec.gov.br/component/content/article?id=57031. Acesso em: 17 de abril de 2018.

ANPUH/SC. Falas direcionadas ao componente curricular de História. $3^{\mathrm{a}}$. Audiência Pública- CNE em Florianópolis (vídeo), 2017b. Disponível em:

http://portal.mec.gov.br/component/content/article?id=57031. Acesso em: $17 \mathrm{de}$ abril de 2018.

ANPUH/SP. 070 Ofício - ANPUH-SP na audiência sobre a Base Nacional Comum Curricular: Conselho Nacional de Educação. 4ª . Audiência Pública em São Paulo, 2017a. Disponível em: http://portal.mec.gov.br/component/content/article?id=57031. Acesso em: 17 de abril de 2018. 
ANPUH/SP. Falas direcionadas ao componente curricular de História. $4^{\mathrm{a}}$. Audiência Pública em São Paulo (vídeo), 2017b. Disponível em:

http://portal.mec.gov.br/component/content/article?id=57031. Acesso em: $17 \mathrm{de}$ abril de 2018.

ASHBY, R. Conceito de Evidência Histórica: exigências curriculares e concepções dos alunos. In: BARCA, I. (org). Educação Histórica e Museus. Braga: CEEP, Universidade do Minho, p. 37 - 58, 2003.

BARDIN, L. Análise de conteúdo. São Paulo: Edições 70, 2016.

BARCA, I. O Pensamento Histórico dos Jovens. Ideias dos adolescentes acerca da provisoriedade da explicação histórica. Braga: CEEP. Universidade do Minho, 2000.

BARCA, I. Aula Oficina: do Projeto à Avaliação. In: BARCA, I. (org). Para uma Educação Histórica de Qualidade. Braga: CEEP, Universidade do Minho, p. 131 - 144, 2004.

BARCA, I. Em torno da epistemologia da História. In: BARCA, I.; GAGO, M. (orgs). Questões de Epistemologia e Investigação em Ensino de História. Braga: CEEP, Universidade do Minho, p. 17 - 28, 2006.

BARRETTO, E. S. S. Tendências recentes do currículo do Ensino Fundamental no Brasil. In: BARRETTO, E. S. S (Org.). Os currículos do Ensino Fundamental para as escolas brasileiras. Campinas, São Paulo: Autores Associados, p. 5-40, 1998.

BARTON, K. Ideias das crianças acerca da mudança através dos tempos: Resultados de investigação nos Estados Unidos e na Irlanda do Norte. In: BARCA, I. (org). Perspectivas em Educação Histórica. Braga: CEEP, Universidade do Minho, p. 13 - 28, 2001.

BITTENCOURT, C. M. As propostas curriculares de história: continuidades e transformações. In: BARRETTO, E. S. S (Org.). Os currículos do Ensino Fundamental para as escolas brasileiras. Campinas, São Paulo: Autores Associados, p. 127-160, 1998.

BITTENCOURT, C. M. Ensino de História: fundamentos e métodos. São Paulo, SP: Cortez, 2004.

BRASIL. Lei n. 5.629/71, que Fixa Diretrizes e Bases para o ensino de $1^{\circ}$ e $2^{\circ}$ graus. Disponível em: http://www.planalto.gov.br/ccivil_03/leis/15692.htm. Acesso em: 05 de maio de 2018.

BRASIL. Constituição da República Federativa do Brasil de 1988. Brasília, DF: Senado Federal: Centro Gráfico. Disponível em: https://www2.senado.leg.br/bdsf/bitstream/handle/id/518231/CF88_Livro_EC91_2016.pdf. Acesso em: 05 de maio de 2018. 
BRASIL. Lei 9.394, de 20 de dezembro de 1996. Estabelece as Diretrizes e Bases da Educação Nacional. Congresso. Brasília, DF. Disponível em: http://www2.camara.leg.br/legin/fed/lei/1996/lei-9394-20-dezembro-1996-362578publicacaooriginal-1-pl.html. Acesso em: 03 de junho de 2018.

BRASIL. Ministério da Educação. Parâmetros curriculares nacionais: introdução aos parâmetros curriculares nacionais 1997. Brasília, DF: MEC/SEF. Disponível em: http://portal.mec.gov.br/seb/arquivos/pdf/introducao.pdf. Acesso em: 03 de junho de 2018.

BRASIL. Conselho Nacional de Educação. Parecer CNE/CES nº 492/2001, aprovado em 3 de abril de 2001 - Aprova as Diretrizes Curriculares Nacionais dos cursos de Arquivologia, Biblioteconomia, Ciências Sociais - Antropologia, Ciência Política e Sociologia, Comunicação Social, Filosofia, Geografia, História, Letras, Museologia e Serviço Social. Disponível em: http://portal.mec.gov.br/escola-de-gestores-da-educacao-basica/323secretarias-112877938/orgaos-vinculados-82187207/12991-diretrizes-curriculares-cursos-degraduacao. Acesso em: 05 de maio de 2018.

BRASIL. Conselho Nacional de Educação. Parecer CNE/CES nº 1.363/2001, aprovado em 12 de dezembro de 2001 - Retifica o Parecer CNE/CES n. ${ }^{\circ}$ 492, de 3 de abril de 2001, que aprova as Diretrizes Curriculares Nacionais dos cursos de Arquivologia, Biblioteconomia, Ciências Sociais - Antropologia, Ciência Política e Sociologia, Comunicação Social, Filosofia, Geografia, História, Letras, Museologia e Serviço Social. Disponível em: http://portal.mec.gov.br/escola-de-gestores-da-educacao-basica/323-secretarias112877938/orgaos-vinculados-82187207/12991-diretrizes-curriculares-cursos-de-graduacao. Acesso em: 05 de maio de 2018.

BRASIL. Conselho Nacional de Educação. Resolução CNE/CES nº 13, de 13 de março de 2002 - Estabelece as Diretrizes Curriculares para os cursos de História. Disponível em: http://portal.mec.gov.br/escola-de-gestores-da-educacao-basica/323-secretarias112877938/orgaos-vinculados-82187207/12991-diretrizes-curriculares-cursos-de-graduacao. Acesso em: 05 de maio de 2018.

BRASIL. Lei ${ }^{\circ} 10.639$, de 9 de janeiro de 2003. Altera a Lei no 9.394, de 20 de dezembro de 1996, que estabelece as diretrizes e bases da educação nacional, para incluir no currículo oficial da Rede de Ensino a obrigatoriedade da temática "História e Cultura Afro-Brasileira", e dá outras providências. Disponível em:

http://www.planalto.gov.br/ccivil_03/leis/2003/110.639.htm. Acesso em: 27 de março de 2018.

BRASIL. Lei n ${ }^{\circ} 11.645$, de 10 de março de 2008. Altera a Lei no 9.394, de 20 de dezembro de 1996, modificada pela Lei no 10.639, de 9 de janeiro de 2003, que estabelece as diretrizes e bases da educação nacional, para incluir no currículo oficial da rede de ensino a obrigatoriedade da temática "História e Cultura Afro-Brasileira e Indígena". Disponível em: http://www.planalto.gov.br/ccivil_03/_ato2007-2010/2008/lei/111645.htm. Acesso em: 27 de março de 2018. 
BRASIL. Resolução no 4, de 13 de julho de 2010. Define Diretrizes Curriculares Nacionais Gerais para a Educação Básica. Disponível em:

http://portal.mec.gov.br/dmdocuments/rceb004_10.pdf. Acesso em: 03 de junho de 2018.

BRASIL. Lei 13.005, de 25 de junho de 2014. Aprova o Plano Nacional de Educação - PNE. Congresso. Brasília, DF. Disponível em: http://www.planalto.gov.br/ccivil_03/_ato20112014/2014/lei/113005.htm. Acesso em: 03 de junho de 2018.

BRASIL. Portaria n ${ }^{\circ}$ 592, de 17 de junho de 2015. Institui Comissão de Especialistas para a Elaboração de Proposta da Base Nacional Comum Curricular. Disponível em http://portal.mec.gov.br/index.php?option=com docman\&view=download\&alias=21361 port-592-bnc-21-set-2015-pdf\&Itemid=30192. Acesso em: 02 de fevereiro de 2018.

BRASIL. Ministério da Educação. Base Nacional Comum Curricular. 2017a. Brasília, DF. Disponível em: http://basenacionalcomum.mec.gov.br/wpcontent/uploads/2018/06/BNCC_EI_EF_110518_versaofinal_site.pdf. Acesso em: 02 de fevereiro de 2018.

BRASIL. Lei ${ }^{\circ} 13.415$, de 16 de fevereiro de 2017. Altera as Leis nos 9.394, de 20 de dezembro de 1996, que estabelece as diretrizes e bases da educação nacional. Congresso. Brasília, DF. Disponível em: http://www.planalto.gov.br/ccivil_03/_ato20152018/2017/lei/113415.htm. Acesso em: 03 de junho de 2018.

BRASIL, Ministério da Educação. O que é a Base Nacional Comum Curricular? 2017c. Disponível em: http://basenacionalcomum.mec.gov.br/\#/site/base/o-que. Acesso em: 02 de fevereiro de 2018.

BRASIL. Parecer CNE no 15/2017, de 15 de dezembro de 2017. Base Nacional Comum Curricular. Brasília, DF. p. 01-46. Disponível em:

http://portal.mec.gov.br/index.php?option=com_docman\&view=download\&alias=78631pcp015-17-pdf\&category_slug=dezembro-2017. Acesso em: 23 de junho de 2018.

BRASIL. Resolução CNE/CP n ${ }^{\circ}$ 2, de 22 de dezembro de 2017. Institui e orienta a implantação da Base Nacional Comum Curricular, a ser respeitada obrigatoriamente ao longo das etapas e respectivas modalidades no âmbito da Educação Básica. Disponível em: http://portal.mec.gov.br/conselho-nacional-de-educacao/base-nacional-comum-curricularbncc. Acesso em: 23 de junho de 2018.

BOGDAN, R. e BIKLEN, S. Investigação qualitativa em educação. Uma introdução à teoria e aos métodos. Porto, Portugal: Porto Editora, 1994.

BORRIES, B. von. Competência do pensamento histórico, domínio de um panorama histórico ou conhecimento do cânone histórico? Educar em Revista; (60), 171-196, 2016. Recuperado de http://www.scielo.br/pdf/er/n60/1984-0411-er-60-00171.pdf. Acesso em: 27 de maio de 2018.

BURKE, Peter. A escrita da História, novas perspectivas. São Paulo. Editora da Universidade Estadual Paulista, 1992. 
CARVALHO FILHO, R. P. de. Currículo e Ensino de História em uma escola da rede Municipal de São Paulo: entre prescrições e práticas. (Tese de doutorado, Faculdade de Educação, Universidade de São Paulo), 2015. Disponível em:http://www.teses.usp.br/teses/disponiveis/48/48134/tde-27102015-091800/pt-br.php. Acesso em: 19 de janeiro de 2018.

CAVALCANTE, I. M. P. Arquiteturas temporais: a prática historiográfica do patrimônio cultural. (Dissertação de Mestrado em História, Universidade de Brasília), 2016. Disponível em:

http://repositorio.unb.br/bitstream/10482/23327/1/2016_IvanaMedeirosPachecoCavalcante.pd f. Acesso em: 19 de janeiro de 2018.

CHARLOT, B. Da relação com o saber. Elementos para uma teoria. Porto Alegre. Artmed Editora, 2000.

CHAGAS, W. F. História e Cultura Afro-Brasileira e Africana na Educação Básica da Paraíba. Educação e Realidade, 42(1), 79-98, 2017. Disponível em:

http://www.scielo.br/pdf/edreal/v42n1/2175-6236-edreal-42-01-00079.pdf. Acesso em: 19 de janeiro de 2018.

CIAMPI, H., Godoy, A. P., Almeida Neto, A. S. de. \& Silva, I. P. da. (2009). O currículo bandeirante: a Proposta Curricular de História no estado de São Paulo. Revista Brasileira de História, 29(58), 361-382. Disponível em:

http://www.scielo.br/pdf/rbh/v29n58/a06v2958.pdf. Acesso em: 19 de janeiro de 2018.

CURY, C. R. J. (2002). A Educação Básica no Brasil. Educação e Sociedade, 23(80), 168200. Disponível em: http://www.scielo.br/pdf/es/v23n80/12929.pdf. Acesso em: 06 de julho de 2020.

DIAS, M. M. S. (2001). O Ensino de História como objeto de pesquisa. Saeculum - Revista de História, 6(7), 97-104. Disponível em:

https://periodicos.ufpb.br/ojs2/index.php/srh/article/view/11267/6382. Acesso em: 14 de novembro de 2018.

FERNANDES, J. R. O. Ensino de História e diversidade cultural: desafios e possibilidades. Cadernos CEDES, 25(67), 378-388, 2005. Disponível em:

http://www.scielo.br/pdf/ccedes/v25n67/a09v2567.pdf. Acesso em: 19 de janeiro de 2018.

FREITAS, L. C. de. Os reformadores empresariais da educação e a disputa pelo controle do processo pedagógico na escola. Educ. Soc., 35(129), 1085-1114, 2014. Disponível em: https://www.scielo.br/pdf/es/v35n129/0101-7330-es-35-129-01085.pdf. Acesso em: 10 de fevereiro de 2021.

FÓRUM DE EDUCAÇÃO INDÍGENA. Falas direcionadas ao componente curricular de História. 1a . Audiência Pública- CNE em Manaus (vídeo), 2017. Disponível em:

http://portal.mec.gov.br/component/content/article?id=57031. Acesso em: $17 \mathrm{de}$ abril de 2018. 
FORQUIN, J. C. Escola e Cultura. As bases sociais e epistemológica do conhecimento escolar. Porto Alegre. Artes Médicas Editora, 1993.

GALIAN, C. V. A. Os PCN e a elaboração de propostas curriculares no Brasil. Cadernos de Pesquisa, São Paulo, 44 (153), p. 648-669, 2014. Disponível em:

https://www.scielo.br/scielo.php?pid=S0100-15742014000300009\&script=sci_arttext. Acesso em: 20 de maio de 2021.

GILAVERTE, A. P. Quem São Os Povos Indígenas Para Os Estudantes? Reflexões sobre O Currículo Básico Comum Do Estado De Minas Gerais. (Dissertação de mestrado, Universidade Federal de São Carlos), 2014. Disponível em:

https://repositorio.ufscar.br/bitstream/handle/ufscar/2741/6428.pdf? sequence=1\&isAllowed= y. Acesso em: 19 de janeiro de 2018.

GONZALEZ, K. P. A nova proposta curricular do Estado de São Paulo: inovações ou continuidades no Ensino de História? Interfaces da Educação, 2 (6), p. 29-36, 2012.

GOODSON, I. F. A construção social do currículo. Lisboa, Universidade de Lisboa: Educa, 1997.

GOODSON, I. F. As políticas de currículo e de escolarização: abordagens históricas. Petrópolis, RJ: Vozes, 2006.

GOODSON, I. F. Currículo: teoria e história. Petrópolis, RJ: Vozes, 2008.

GUIMARÃES, E. A. O lugar da experiência nos currículos de História (1975-1998). (Dissertação de mestrado, Faculdade de Educação, Universidade de São Paulo), 2007. Recuperado de http://www.teses.usp.br/teses/disponiveis/48/48134/tde-19042007-155633/ptbr.php. Acesso em: 19 de janeiro de 2018.

HELENO, C. R. Contribuição à crítica da Base Nacional Comum Curricular - a máscara do conformismo na educação do Banco Mundial. (Dissertação de mestrado Acadêmico em Educação, Universidade Estadual de Feira de Santana), 2017. Disponível em: http://tede2.uefs.br:8080/handle/tede/600. Acesso em: 19 de janeiro de 2018.

HOBSBAWN, E. Sobre história. São Paulo: Companhia das Letras, 1998.

INSTITUTO AYRTON SENNA. Ideias para o desenvolvimento de competências socioemocionais: resiliência emocional, 2020. Disponível em: https://institutoayrtonsenna.org.br/content/dam/institutoayrtonsenna/documentos/institutoayrton-senna-macrocompetencia-resilienciaemocional.pdf?utm_source=site\&utm_medium=hub-1507. Acesso em: 03 de maio de 2020 .

KNAUSS, P. Conhecimento histórico escolar. In: FERREIRA, M. M; OLIVEIRA, M.D. (coord). Dicionário de Ensino de História. Rio de Janeiro: FGV Editora, 2019.

LAVAL, C. A escola não é uma empresa: o neoliberalismo em ataque ao ensino público. São Paulo: Boitempo, 2019. 
LEE, P. Progressão da compreensão dos alunos em História. In: BARCA, I. (org). Perspectivas em Educação Histórica. Braga: CEEP, Universidade do Minho, p. 13 - 28, 2001.

LEE, P. "Nós fabricamos carros e eles tinham que andar a pé": compreensão da vida no passado. In: BARCA, I. (org). Educação Histórica e Museus. Braga: CEEP, Universidade do Minho, p. 19 - 36, 2003.

LEE, P. Educação Histórica, consciência Histórica e Literacia Histórica. In: BARCA, I. (org). Estudos de Consciência Histórica na Europa, América, Ásia e África. Braga: CEEP, Universidade do Minho, p. 11 - 32, 2008.

LEE, P. Literacia histórica e história transformativa. Educar em Revista, (60), 107-146, 2016. Disponível em: https://revistas.ufpr.br/educar/article/view/45979/28511. Acesso em: 19 de janeiro de 2018

MARIA, A. N. O currículo e o Ensino de História nos anos finais do Ensino Fundamental. Dissertação de Mestrado. Porto Alegre: Faculdade de Educação, 2013.

MARINS, C. F. Currículo De História No Ensino Médio E Avaliação De Egressos: A Relação Entre Os Documentos Orientadores Da Disciplina E Os Exames Oficiais (ENEM E Vestibulares) - 2009-2013. (Tese de doutorada, Faculdade de educação, Universidade de São Paulo), 2016. Disponível em: http://www.teses.usp.br/teses/disponiveis/48/48134/tde31082016-150412/. Acesso em: 25 de janeiro de 2018.

MARTINS, K. S.B. da S. Identidades amazônicas, saberes e currículo das escolas de Ensino Fundamental em Parintins-AM. (Tese de doutorado em Educação, Universidade Federal do Amazonas), 2016. Disponível em: http://tede.ufam.edu.br/handle/tede/5336. 25 de janeiro de 2018.

MATTOZZI, I. Currículo de História e educação para o patrimônio. Educação em Revista, (47), 135-155, 2008. Disponível em: http://www.scielo.br/pdf/edur/n47/09.pdf. 25 de janeiro de 2018.

MOREIRA, R. 049 Ofício - Moral e Cívica e OSPB na BNCC para mudar e libertar o Brasil! Audiência pública do MEC - Base Nacional Comum Curricular, s.d. Disponível em: http://portal.mec.gov.br/component/content/article?id=57031. Acesso em: 04 de abril de 2018.

MOVIMENTO TODOS PELA BASE. 069 Ofício - Síntese das leituras críticas/recomendações dos especialistas, 2017a. Disponível em: http://portal.mec.gov.br/component/content/article?id=57031. Acesso em: 04 de abril de 2018.

MOVIMENTO TODOS PELA BASE. 131 Ofício - O Desenvolvimento Integral na Base Nacional Comum Curricular: recomendações para Subsidiar Parecer do CNE - Conselho Nacional de Educação. Movimento pela Base. Com contribuições de: Centro de Referências em Educação Integral Instituto Inspirare; Instituto Ayrton Senna; CIEB - Centro de Inovação 
para a Educação Brasileira; Sociedade Brasileira de Computação - SBC em setembro de 2017, 2017b. Disponível em: http://portal.mec.gov.br/component/content/article?id=57031. Acesso em: 04 de abril de 2018.

NAKAD, F. A. e SKAAF, G. J. P. Desafios para a implementação da Base Nacional Comum Curricular. (Dissertação de Mestrado Profissional em Gestão e Políticas Públicas, Fundação Getúlio Vargas), 2017. Disponível em: http://hdl.handle.net/10438/19945. Acesso em: 21 de janeiro de 2018

OZÓRIO, A. M. O ensino da geografia e sua especificidade na base nacional comum curricular brasileira: uma cartografia das ausências. (Tese de doutorado em Educação, Programa de Estudos Pós-Graduados em Educação, Pontifícia Universidade Católica de São Paulo), 2018. Disponível em: https://tede2.pucsp.br/handle/handle/20934. Acesso em: 19 de janeiro de 2018

PACHECO, J. 129 Ofício - 11 de setembro de 2017, Brasília, 2017. Disponível em: http://portal.mec.gov.br/component/content/article?id=57031. Acesso em: 04 de abril de 2018.

PACHECO, J. Estudos Curriculares. Para a compreensão crítica da educação. Porto: Porto Editora, 2005.

PONCIANO, D. D. História E Cultura Afro-Brasileiras No Currículo de História do $6^{\circ}$ Ao $9^{o}$ Anos, da Rede Oficial do Estado de São Paulo. (Dissertação de mestrado, Universidade do Oeste Paulista), 2011. Disponível em: http://bdtd.unoeste.br:8080/tede/handle/tede/71. Acesso em: 19 de janeiro de 2018.

ROCHA, N. F. E. Base nacional comum curricular e micropolítica: analisando os fios condutores. (Dissertação de mestrado em Educação, Universidade Federal da Paraíba), 2016. Disponível em: http://tede.biblioteca.ufpb.br:8080/handle/tede/8786. Acesso em: 19 de janeiro de 2018.

ROCHA, R. Identidades e Ensino de História: um estudo em escolas do Rio Grande do Norte. Tese de Doutorado. São Paulo: FEUSP, 2001a.

ROCHA, U. Currículos de história do Rio de Janeiro, cotidiano escolar e ensino: recuperando 'elos perdidos'. Tese de Doutorado. São Paulo: FEUSP, 2001 b.

RODRIGUES, E. Reformando o Ensino de História: lições de continuidade. História (São Paulo), 23(1-2), 49-68, 2004. Disponível em: http://www.scielo.br/pdf/his/v23n12/a04v2312.pdf. 25 de janeiro de 2018.

RODRIGUES, V. A. da C. A Base Nacional Comum Curricular em questão. (Dissertação de mestrado em Educação, Programa de Estudos Pós-Graduados em Educação, Pontifícia Universidade Católica de São Paulo), 2016. Disponível em:

https://tede2.pucsp.br/handle/handle/19888. Acesso em: 19 de janeiro de 2018

SACRISTÁN, G. J. Currículo: uma reflexão sobre a prática. Porto Alegre, RS: Artmed, 2000. 
SACRISTÁN e GOMEZ, A. P. Compreender e transformar o ensino. Porto Alegre, RS: Artmed, 1998.

SCHMIDT, M. A. M. dos S. e Garcia, T. M. F. B. Discutindo o currículo "por dentro": contribuições da pesquisa etnográfica: contribuições da pesquisa etnográfica. Educar em Revista, (17), 139-149, 2001 Disponível em: http://www.scielo.br/pdf/er/n17/n17a11.pdf. Acesso em: 20 de janeiro de 2018.

SILVA, A. G. da; Siquelli, S. A. Modernidade e transformações do século XXI: a disciplina de História no Ensino Fundamental II. Revista Ibero-Americana de Estudos em Educação, 11(1), p. 49-66, 2016.

SILVA, M. A. da; FONSECA, S. G. Ensino de História hoje: errâncias, conquistas e perdas. Rev. Bras. Hist., São Paulo, 30 (60), p. 13-33, 2010. Disponível em:

https://www.scielo.br/pdf/rbh/v30n60/a02v3060.pdf. Acesso em: 13 de março de 2021.

SILVA, R. P. da. Ensino de Geociências na Educação Básica: uma análise dos planos de estudos de uma rede municipal de ensino. (Dissertação de mestrado, Centro Universitário UNIVATES), 2017. Disponível em: http://hdl.handle.net/10737/1573. Acesso em: 19 de janeiro de 2018.

SILVA, T. T. da. Documentos de identidade: uma introdução às teorias do currículo. Belo Horizonte: Autêntica Editora, 2014.

STECA, L. C. A Prática Docente do Professor de História: Um Estudo Sobre O Ensino de História Do Paraná Nas Escolas Estaduais de Londrina. (Dissertação de mestrado, Centro de Educação, Comunicação e Artes, Programa de Pós-Graduação em Educação, Universidade Estadual de Londrina), 2008. Disponível em:

http://www.bibliotecadigital.uel.br/document/?code=vtls000128880. Acesso em: $21 \mathrm{de}$ janeiro de 2018.

TAHARA, A. K. Práticas Corporais De Aventura: Construção Coletiva De Um Material Didático Digital. (Tese de doutorado, Universidade Estadual Paulista), 2017. Disponível em: http://hdl.handle.net/11449/152377. Acesso em: 19 de janeiro de 2018.

THOMPSON, E. P. Costumes em comum. São Paulo: Companhia das Letras, 1998.

UNDIME. 222 Ofício Alessio Costa Lima - Seminário Base Nacional Comum Curricular em debate: desafios, perspectivas e expectativas, realizado nos dias 20 e 21 de janeiro de 2016, em Brasília/ DF, 2017. Disponível em:

http://portal.mec.gov.br/component/content/article?id=57031. Acesso em: 04 de abril de 2018.

YOUNG, M. F. D. Para que servem as escolas? Educação \& Sociedade, 28(101), 1287-1302, 2007. Disponível em: http://www.scielo.br/scielo.php?pid=S0101-

73302007000400002\&script=sci_abstract\&tlng=pt. Acesso em: 15 de abril de 2020. 
YOUNG, M. F. D. O futuro da educação em uma sociedade do conhecimento: o argumento radical em defesa de um currículo centrado em disciplinas. Revista Brasileira de Educação, 16(48), 609-8010, 2011.

YOUNG, M. F. D. Por que o conhecimento é importante para as escolas do século XXI?. Cad. Pesquisa. 46(159), 18-37, 2016. Disponível em:

http://dx.doi.org/10.1590/198053143533. Acesso em: 10 de fevereiro de 2021. 
Anexos 
ANEXO A - Documento encaminhado ao CNE pela ANPUH-SC (2017) - Ofício 059 Parecer da ANPUH-SC sobre a terceira versão da Base Nacional Comum Curricular de História.

\section{ANPUH Parecer da ANPUH-sc sobre a Terceira Versão da \\ ASSOCLACAO NACIONAL DE HISTORLA Base Nacional Comum Curricular de História}

Aos conselheiros do Conselho Nacional de Educação,

A seção catarinense da Associação Nacional de História (ANPUH-SC) vem por meio deste apresentar algumas considerações sobre a terceira versão da Base Nacional Comum Curricular (BNCC).

Primeiramente, é preciso destacar que há mudanças substanciais nas três versões propostas.

A primeira versão gerou moções de repúdio, por diferentes motivos, de parte do meio acadêmico e de uma parcela da sociedade civil. Ao priorizar a história brasileira e suas interações com os "mundos americanos" e os "mundos africanos", a primeira versão da BNCC foi criticada por excluir a história europeia, sobretudo a Antiga e a Medieval, em nome de um suposto combate ao eurocentrismo dos currículos. Entre os africanistas, a BNCC também foi criticada por suprimir a história da África antes do século XVI, o que contribuiria para manter a história do continente africano a reboque da "grande história" protagonizada pelos europeus. Por meio de nota oficial, a Associação Nacional de História (ANPUH) criticou a celeridade da formulação da base sem uma discussão ampla e solicitou a reformulação da equipe de História de modo a contemplar suas diferentes subáreas.

Se, na primeira versão, a crítica à BNCC focava a desestruturação do currículo tradicional em nome da reformulação da visão eurocêntrica de História e da valorização das histórias indígenas e africanas, as críticas à segunda versão foram quase opostas. Ao reformular a BNCC de História, a equipe elaboradora da segunda versão foi criticada por reificar antigos postulados tradicionais, relegando novamente ao segundo plano a história africana e indígena sob a vaga denominação de "temas integradores". Ou seja, em resposta às críticas à primeira versão, montou-se uma segunda, de viés tradicional, com enfoque cronológico e permanência da chamada "grande narrativa".

A terceira versão, proposta pelo atual governo após o desenlace da trama que articulou a deposição da presidenta Dilma Rousseff, padece de problemas que estão umbilicalmente relacionados ao projeto político que vem sendo implementado pelos partidos que tomaram o poder.

A primeira versão da BNCC de História, disponibilizada para consulta pública no final de 2015 , foi eivada de polêmica. Alguns ditos especialistas em educação e comentaristas dos grandes meios de comunicação bradaram que a BNCC era a expressão do "lulopetismo" e do "bolivarianismo". Denunciaram a perda irreparável do estudante por não ter a oportunidade de conhecer o conceito de cidadania ateniense. Ora, nós, que estamos nas salas de aula do ensino básico, sabemos que a forma e a qualidade com que se discute o conceito de cidadania em Atenas, bem como os demais conceitos do componente curricular História, passa ao largo da BNCC. Isso não significa, entretanto, desconsiderar o papel fundamental desta na composição de currículos e materiais didáticos.

Consideramos o governo Temer, que propõe esta nova versão da BNCC, um governo ilegítimo, visto que assaltou o sufrágio dos brasileiros para colocar no poder os grupos políticos derrotados nas urnas. Todavia, não consideramos o conteúdo da terceira versão da Base como a expressão inexorável da fé antidemocrática dos atuais mandatários do poder. $\mathrm{O}$ documento gera polêmicas e pode ser criticado tanto à direita quanto à esquerda - assim como o foram as outras duas versões. O que parece mais problemático é a construção da BNCC dentro do projeto político para a educação brasileira do governo Temer.

A despeito de vermos com ressalvas o uso exacerbado do termo "competências" na atual versão, não parece haver grandes problemas, por exemplo, nas competências gerais da Base. Concordamos que o compromisso da educação brasileira é a "construção de uma sociedade justa, democrática e inclusiva". Assim como percebemos que as propostas do governo Temer de congelar os investimentos públicos por 20 anos,

ANPUH-SC - Associação Nacional de História - Seção Santa Catarina - Endereço: UFSC - Centro de Filosofia e Ciências Humanas - Depto. de História - Sala 12. Florianópolis/SC - CEP: 88040-900. Telefone: (48) 3721-3522 
Parecer da ANPUH-SC sobre a Terceira Versão da Base Nacional Comum Curricular de História

reduzir direitos trabalhistas e inviabilizar a aposentadoria das pessoas mais pobres do país não é nem justa, nem inclusiva e muito menos democrática, visto que é um projeto derrotado nas urnas em 2014.

Quanto aos conteúdos propostos, a terceira versão da BNCC não traz contribuições inovadoras. Inicia nas "cavernas" e vai até a Constituição de 1988. Persegue uma lógica já presente em grande parte dos livros didáticos nacionais, eurocêntrica e exclusivamente cronológica, em que pese algumas menções sobre a história africana, afro-brasileira e indígena, bem como sobre questões de gênero. A esse respeito, inclusive, é importante destacar a pouca relevância dada pela terceira versão da BNCC à diversidade cultural, aos direitos humanos, aos debates das relações de gênero, as questões étnico-raciais, temas caros à nossa área do conhecimento e fundamentais para uma discussão qualificada sobre nossa sociedade atual e tão importantes para formação de um sujeito histórico em uma "sociedade justa, democrática e inclusiva", como projetado pela BNCC

Outra questão de fundo do Componente curricular História que precisa ser apontada e demanda necessária discussão diz respeito à percepção do "tempo". A proposta encampada pela terceira versão da BNCC organiza a disciplina a partir de um viés único e linear tendo como referência a centralidade da história europeia sem abrir grandes possibilidades para problematizar a complexidade temporal. Ainda, neste caminho, causa inquietação e grande preocupação a BNCC não encampar as discussões do campo de referencia da história do tempo presente. Um ensino de História estabelecido pela relação do passado pelo passado sem articulações com o tempo vivido pelo estudante o torna pouco significativo e passa longe de produzir sentido para a formação de uma "sociedade justa, democrática e inclusiva".

Contudo, preocupa-nos ter de emitir um parecer sobre a BNCC dos anos finais do Ensino Fundamental sem que tenhamos acesso à BNCC do Ensino Médio. Afinal, a proposta enviada pelo governo Temer - através de medida provisória, diga-se de passagem - esquarteja o Ensino Médio com seus itinerários formativos. Ou seja, é, no mínimo, complexo opinar sobre a pertinência da BNCC dos Anos Finais do Ensino Fundamental sem ter uma dimensão do conjunto que compreende a formação do estudante de educação básica.

Portanto, não concordamos com a estratégia de audiências públicas de "caráter consultivo, mas não deliberativo" de um documento que veio incompleto, pois não consta o Ensino Médio. Não somos contrários à existência de uma base, mas sim desta base. Principalmente, pela forma como foi gestada. Queremos ser chamados para discutir com o governo sobre esta e outras questões que se impõem quando falamos em educação no Brasil. O ministro da Educação - que na semana que escrevemos este documento desligou-se de seu cargo para votar contra a abertura de investigação para apurar crime de corrupção passiva perpetrado pelo atual presidente - já abriu as portas de seu gabinete para ouvir as opiniões de Alexandre Frota e dos membros do MBL. Por que não dialogar conosco para que possamos propor mudanças na Base?

Para finalizar, externamos nossa preocupação com a fala da professora Maria Helena Guimarães Castro, presidenta do Comitê Gestor da terceira versão da BNCC e da reforma do ensino médio e secretária executiva do Ministério da Educação. Em audiência com o PROIFES-Federação, no dia 16 de fevereiro de 2017, a secretária defendeu a cobrança de mensalidades nas universidades e institutos federais. Em matéria, publicada na Folha de São Paulo, de 17 de maio de 2016, o jornalista Paulo Saldana afirma que Maria Helena Guimarães Castro e Maria Inês Fini representariam a influência marcante do PSDB na gestão do ministro Mendonça Filho, do DEM. Ainda segundo o jornal, as duas atuaram juntas na Secretária de Educação do estado de São Paulo no governo José Serra e foram responsáveis pelo sistema de bonificação por mérito dos professores da rede paulista, em 2008. Portanto, consideramos imprescindível a discussão sobre a BNCC, bem como sobre a reforma do ensino médio, e acreditamos que ela deva ser conjugada com uma política ampla de

ANPUH-SC - Associação Nacional de História - Seção Santa Catarina - Endereço: UFSC - Centro de Filosofia e

Ciências Humanas - Depto. de História - Sala 12. Florianópolis/SC - CEP: 88040-900. Telefone: (48) 3721-3522 


\section{ANPUH}

ASSOCLACAONACIONAL DEHISTORL

Parecer da ANPUH-SC sobre a Terceira Versão da Base Nacional Comum Curricular de História

educação que garanta salários dignos aos professores, ampliação das vagas e das políticas de acesso às universidades, principalmente para os mais pobres.

Entretanto, em nossa concepção, essas políticas não se fazem com reformas através de medidas provisórias, cobranças de mensalidades em institutos e universidades, congelamento de investimentos públicos tampouco com arrocho salarial e bonificações por mérito.

Florianópolis, 11 de agosto de 2017

ANPUH-SC - Associação Nacional de História - Seção Santa Catarina - Endereço: UFSC - Centro de Filosofia e Ciências Humanas - Depto. de História - Sala 12. Florianópolis/SC - CEP: 88040-900. Telefone: (48) 3721-3522 
ANEXO B - Documento encaminhado ao CNE pela ANPUH-SP (2017) - Ofício 070 ANPUH-SP na Audiência sobre a Base Nacional Comum Curricular. Conselho Nacional de Educação - Comissão da Base Nacional Comum Curricular

\title{
ANPUH sP \\ ASSOCIAÇÃO NACIONAL DE HISTÓRIA SEÇÃOSÃO PAULO
}

\section{ANPUH-SP NA AUDIÊNCIA SOBRE A BASE NACIONAL COMUM CURRICULAR ${ }^{1}$}

\author{
Conselho Nacional de Educação - Comissão da Base Nacional Comum Curricular \\ Audiência pública - Região Sudeste
}

São Paulo, 25.ago.2017

Agradecemos em nome da Associação Nacional de História - seção São Paulo, a possibilidade de apresentar nossos posicionamentos sobre a Base Nacional Comum Curricular nesta audiência pública. De início, ao considerar as dinâmicas do processo de elaboração, debate e futura implementação da Base, na condição de professores, professoras, historiadores e historiadoras atuantes no estado de São Paulo, indagamos sobre as funções dos diferentes agentes em ação nesse processo: qual o papel dos conselhos nacional e estaduais de educação? Como foram incorporadas as milhares de contribuições apresentadas para as versões anteriores ou tratase apenas de mais uma forma de disseminar a ideia de "consulta democrática" para a construção da BNCC?

Cientes das informações oficiais contidas nos documentos da Base acerca desses pontos, discordamos da afirmação de que "a Base não é currículo" e de que se trata apenas de uma "referência nacional para a definição dos currículos dos sistemas e das redes escolares dos Estados" É nosso entendimento, a partir das concepções historicamente constituídas de currículo, que discutimos aqui, sim, um currículo já antecipadamente definido por gestores, organizações e políticos comprometidos com ordem mundial do capitalismo em seus múltiplos enredamentos com as políticas de governo de um Estado gerenciador de interesses privados. Essa submissão fica explícita quando lembramos que há exatamente uma semana, dia 18 de agosto, o Conselho Nacional de Secretarias de Educação (CONSED) divulgava em evento da entidade ocorrido em Belo Horizonte o Guia de Implementação da Base Nacional Comum Curricular elaborado pelo Movimento pela Base Nacional Comum. O Guia é explícito ao afirmar que não há necessidade de aguardar a homologação da BNCC para se iniciar a implantação e orienta sobre os procedimentos, ainda que sequer as audiências, análises e pareceres do Conselho Nacional de Educação estejam concluídas.

Portanto, qual seria a autonomia do Conselho Nacional de Educação em eventualmente acolher as considerações expostas nessas audiências? Qual a efetiva submissão da Base aos preceitos legais aos quais remete textualmente, como a Lei de Diretrizes e Bases da Educação e o Plano Nacional de Educação?

\footnotetext{
${ }^{1} \mathrm{O}$ texto preparado pela diretoria da ANPUH-SP foi lido durante a audiência pública com ligeiras modificações e supressões, para adequação ao tempo disponibilizado, sem prejuízo da argumentação. ${ }^{2}$. Afirmação registrada no site oficial da Base e reiterada pela Secretária Executiva do MEC em: CASTRO Maria Helena Guimarães de. A Base não é currículo. O Globo, 12/04/2017. Disponível em: https://oglobo.globo.com/opiniao/a-base-nao-curriculo-21194267. Acesso em 20 ago.2017. A definição como referência nacional encontra-se também no documento oficial da terceira versão: MINISTÉRIO DA EDUCAÇÃO. Base Nacional Comum Curricular: educação é a base. Versão 3. Brasília-DF: MEC, 2017. p.8.

Av. Prof. Dr. Lineu Prestes, 338 - Sala N/Prédio de História e Geografia - Cidade Universitária - São Paulo/SP - CEP 05508-900

Tel/Fax: (11) 3091-3047 - anpuhsp@usp.br - http://www.anpuhsp.org.br
} 


\section{ANPUH}

ASSOCIAÇ̃̃O NACIONAL DE HISTÓRIA SEÇÃO SÃO PAULO

As contribuições que apresentamos tomam como premissa a concepção de um ensino de história desenvolvido por professores com autonomia quanto aos procedimentos de ensino e aprendizagem, considerando a possibilidade de selecionar conteúdos que atendam às expectativas de alunos de diferentes condições sociais, econômicas e culturais. Contrariamente a estes pressupostos a BNCC de História reduz ou elimina as possibilidades de estudos das histórias locais relacionadas aos processos históricos mais abrangentes. Mantém para os anos iniciais uma organização de tempo cronológico e limitado ao grupo familiar; mantém as festividades de datas cívicas como marco da compreensão da história nacional; mantém ainda para as séries posteriores do ensino fundamental uma abordagem eurocêntrica da história, que mais uma vez descarta a possibilidade de entendimento mais amplo da história da sociedade brasileira inserida nas sociedades americanas em sua diversidade cultural, social e econômica; mantém reiteradamente o estudo do Brasil a partir de uma suposta dimensão periférica no sistema capitalista. Neste sentido a lógica da história do capitalismo se mantem ao delimitar estudos da Antiguidade apenas articulados ao conceito de "civilização" que elimina outros povos. As sociedades indígenas americanas e africanas não existiam na Antiguidade? As sociedades indígenas e africanas devem ser estudadas apenas após o contato com os brancos "civilizados"? E outros povos como os chineses também não podem ser considerados "civilizados"? Manifestamos nossa preocupação em relação a uma seleção de conteúdos que reitera a ênfase no estudo histórico centrado nos feitos do progresso do capitalismo e limita a possibilidade de estudos históricos pautados em outras possibilidades de abordagem, fartamente demonstradas na historiografia. Também limita uma formação política ao evitar estudos do tempo presente uma vez que delimita os estudos da política brasileira que não podem ultrapassar a década de 1980 .

Finalmente, a Base limita a aprendizagem enfatizando-se o processo avaliativo cujo pressuposto está centrado no desenvolvimento da capacidade de responder aos testes - um sistema basicamente mnemônico, ou seja, uma nova versão do método catequético. A dinâmica que rege a organização progressiva e detalhada em descritores sequenciados apresenta um "rumo claro" o preparo de estudantes preponderantemente com vistas à aferição de desempenho, em especial aquelas destinadas a avaliações externas (como as provas SARESP, PISA etc.), diluindo-se os métodos de estudos em meras leituras de sistemas apostilados de treinamento discente. Esse currículo avaliado traz consequências não apenas para a formação intelectual, cultural e política das futuras gerações de estudantes como também atua diretamente sobre o trabalho e a formação docente, reduzindo o trabalho intelectual de professores à empobrecedora lógica do consumo de materiais simplificados, não raramente envolvidos em facilitadoras fórmulas sedutoras das tecnologias digitais de informação conforme se vê nas práticas escolares do Estado de São Paulo e seu sistema apostilado em plena difusão que torna o professor um simples "aplicador" de uma matéria que será avaliada exteriormente.

Por não podermos nos deter aqui em detalhamentos acerca da Base, considerando-se os limites do formato determinado para esta audiência, gostaríamos de registrar essas ponderações voltadas à fundamentação do processo de elaboração, discussão e implementação da mesma. E o fazemos com grande preocupação. Analisado em seu conjunto, esse processo compromete os princípios democráticos fundamentais para a constituição de bases sociais efetivamente emancipadoras, pautadas no conhecimento crítico da sociedade e de sua história, sem submissões a valores e compromissos não educacionais e sem fortes vínculos sociais. Entendemos ser a Base configurada de modo a reforçar e, mais grave ainda, naturalizar concepções e valores

Av. Prof. Dr. Lineu Prestes, 338 - Sala N/Prédio de História e Geografia - Cidade Universitária - São Paulo/SP - CEP

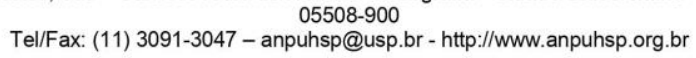




\section{ANPUH $\mathrm{sP}$}

ASSOCIAÇÃO NACIONAL DE HISTÓRIA SEÇÃOSÃO PAULO

individualistas que estimulam desigualdades, concorrências, ranqueamentos, "empreendedorismos", em detrimentos de valores comprometidos com a democracia, com a solidariedade, com a colaboração mútua, com a diversidade de pensamento, convertendo-se na prática em instrumento contrário aos princípios que enuncia: "direcionar a educação brasileira para a formação humana integral e para a construção de uma sociedade justa, democrática e inclusiva". ${ }^{3}$ Fossem esses princípios de fato os norteadores da proposta poderíamos estar nesta audiência saudando a iniciativa.

${ }^{3}$ MINISTÉRIO DA EDUCAÇ̃̃O. Base Nacional Comum Curricular: educação é a base. Versão 3. Brasília-DF: MEC, 2017. p.7.

Av. Prof. Dr. Lineu Prestes, 338 - Sala N/Prédio de História e Geografia - Cidade Universitária - São Paulo/SP - CEP

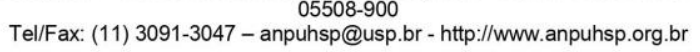

